JEANE LIMA E SILVA CARNEIRO

\title{
O cuidado do idoso na atenção primária sob o olhar da autonomia: um estudo em bairro central da cidade de São Paulo
}

\author{
Dissertação apresentada à Faculdade de \\ Medicina da Universidade de São Paulo \\ para obtenção do título de Mestre em \\ Ciências \\ Programa de Saúde Coletiva \\ Orientador: Prof. Dr. José Ricardo de \\ Carvalho Mesquita Ayres
}

(Versão corrigida. Resolução CoPGr 6018/11, de 1 de novembro de 2011. A versão original está disponível na Biblioteca da FMUSP)

São Paulo

2020 
JEANE LIMA E SILVA CARNEIRO

O cuidado do idoso na atenção primária sob o olhar da autonomia: um estudo em bairro central da cidade de São Paulo

Dissertação apresentada à Faculdade de Medicina da Universidade de São Paulo para obtenção do título de Mestre em Ciências

Programa de Saúde Coletiva Orientador: Prof. Dr. José Ricardo de Carvalho Mesquita Ayres

São Paulo

2020 


\section{FICHA CATALOGRÁFICA}

\section{Dados Internacionais de Catalogaçăo na Publicaçăo (CIP)}

Preparada pela Biblioteca da

Faculdade de Medicina da Universidade de São Paulo

Creproduçāo autorizada pelo autor

Carneiro, Jeane Lima e Silva

o cuidado do idoso na atenção primária sob o

olhar da autonomia : um estudo em bairro central da

cidade de São Paulo / Jeane Lima e Silva Carneiro. -

- Săo Paulo, 2020.

Dissertação (mestrado)--Faculdade de Medicina da Universidade de São Paulo.

Programa de Saúde Coletiva.

orientador: José Ricardo de Carvalho Mesquita Ayres.

Descritores: 1. Envelhecimento 2.Saúde do idoso

3. Atenção primária à saúde 4.Autonomia relacional

5 . Saúde pública 6 . Vulnerabilidade em saúde

7. Cuidado 8.Hermenêtutica

$\mathrm{USP} / \mathrm{FM} / \mathrm{DBD}-135 / 20$

Responsável: Erinalva da Conceiçāo Batista, CRB-8 6755 


\section{DEDICATÓRIA}

Ao melhor Amigo, ao meu parceiro de vida e aos frutos desse amor. 


\section{AgRADECIMENTOS}

Agradeço, com o coração realmente grato, a todos que partilharam, colaboraram e tornaram possível o processo de construção deste trabalho. Há muita gente boa nesse vasto mundo!

A José Ricardo Ayres, que em sua orientação vive e demonstra Cuidado. Quanto conhecimento, simplicidade e acolhimento! Os aprendizados se somam a cada encontro.

Aos colegas, professores e funcionários do Departamento de Medicina Preventiva que possibilitaram tantas trocas. Em especial aos queridos colegas do grupo de Hermenêutica Filosófica. Foram muitas conversas terapêuticas, trocas e aprendizados. Dos funcionários, agradecimento especial à Lilian, por tantos esclarecimentos e à Miriam por tanta empatia e disponibilidade para a revisão.

Aos professores Ângela Maria Machado de Lima, Guita Grin Debert e Ricardo Teixeira pelas preciosas observações no exame de qualificação.

A todos os profissionais do Centro de Saúde que sediou este estudo. Impossível colocar em palavras o carinho e admiração que tenho por vocês!

A cada um dos idosos que compartilhou e me confiou memórias, sentimentos e um pouco de sua vida nas entrevistas.

À queridíssima Juliana Moura, pelas sugestões que muitas vezes apontaram para um norte, pelas notas mágicas resumidas em quadrados e setas (construídas durante uma carona ou uma conversa por telefone) e pelos gravadores. "Consciência plena!".

A Leo, "sogramãe", que me socorreu em vários momentos em que a vida precisava se acalmar pra pesquisa andar. Aos amigos e familiares que sempre apoiaram e me ajudaram a perseverar.

Ao meu amado Helio e às nossas meninas. Obrigada pelo apoio e compreensão em todos os sentidos. Vocês me movem!

A Deus, pela oportunidade e pelas pessoas que colocou ao meu redor. 
"[Eu] Pensava que nós seguíamos caminhos já feitos, mas parece que não os há. O nosso ir faz o caminho." (C.S. Lewis) 


\section{LISTA DE ILUSTRAÇÕES}

Figura 1 - Sumário das ações propostas conforme o perfil de

funcionalidade.

Figura 2 - Dispositivos intersetoriais em articulação em rede para o cuidado do idoso 19

Figura 3 - $\quad$ Usuários do CS - total e por equipe ........................................45

Figura 4 - Território - Equipe A ………………...............................

Figura 5 - Território - Equipe B ......................................................48

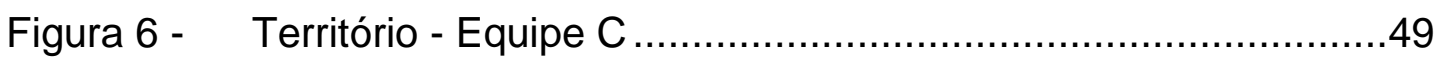

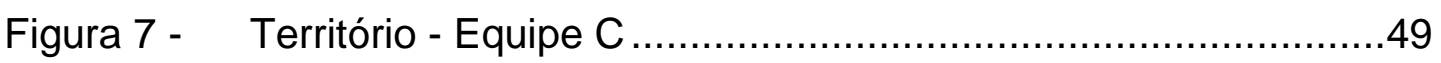

Quadro 1 - Caracterização geral dos entrevistados idosos ......................52

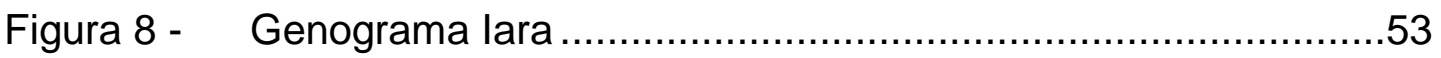

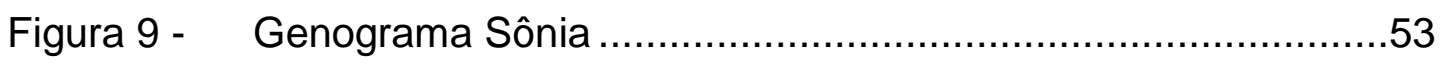

Figura 10 - Genograma Carmen.......................................................

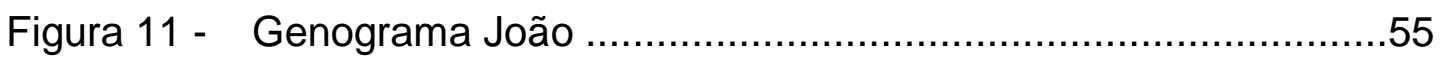

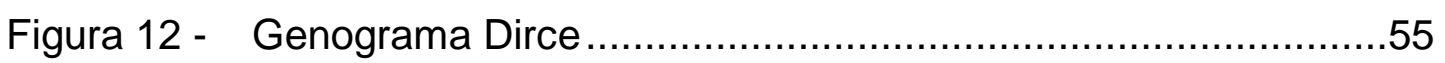

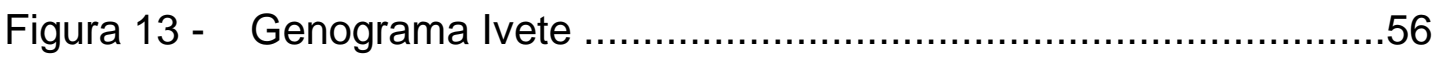

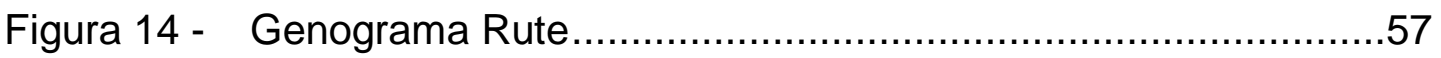

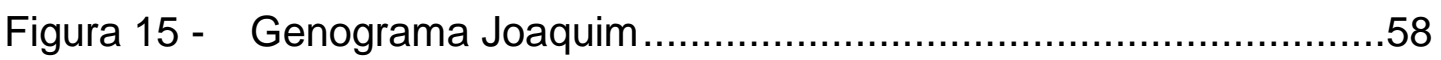

Quadro 2 - Relação entrevistados profissionais de saúde e sua função......59 


\section{LISTA DE ABREVIATURAS E SIGLAS}

$A B$

ACS

$A D$

AME

AMPI ou AMPI-AB

APS

AVD

CRI

CS

DCNT

e.g

ELSI

EMAD

eSF

ESF

et al.

i.e

ILPI

MCP

MFC

NASF-AB

OMS

PAI

$\mathrm{PNI}$

PNSPI

PTS
Atenção Básica

Agente Comunitário de Saúde

Atenção domiciliar

Ambulatório Médico de Especialidades

Avaliação Multidimensional da Pessoa Idosa da Atenção

Básica

Atenção Primária à Saúde

Atividades de Vida Diária

Centro de Referência do Idoso

Centro de Saúde

Doenças crônicas não transmissíveis

por exemplo

Estudo Longitudinal da Saúde dos Idosos Brasileiros

Equipe Multiprofissional de Atenção Domiciliar

Equipe Saúde da Família

Estratégia saúde da Família

e outros

isto é

Instituição de Longa Permanência para Idosos

Medicina Centrada na Pessoa

Médico (Medicina) de Família e Comunidade

Núcleo Ampliado de Apoio à Saúde da Família - Atenção

Básica

Organização Mundial da Saúde

Programa Acompanhante de Idoso

Política Nacional do Idoso

Política Nacional de Saúde da Pessoa Idosa

Projeto Terapêutico Singular 
RAS

SAMU

SASF

SUS

UBS

URSI
Rede de Atenção à Saúde

Serviço de Atendimento Móvel de Urgência

Serviço de Assistência Social à Família e Proteção Social

Básica no Domicílio

Sistema Único de Saúde

Unidade Básica de Saúde

Unidade de Referência à Saúde do Idoso 


\section{RESUMO}

Carneiro JLS. O cuidado do idoso na atenção primária sob o olhar da autonomia: um estudo em bairro central da cidade de São Paulo [dissertação]. São Paulo: Faculdade de Medicina, Universidade de São Paulo; 2020.

A proporção de idosos na população vem aumentando em quase todo o globo, devido ao aumento da expectativa de vida e redução da fecundidade. $O$ envelhecimento é uma conquista da sociedade moderna, vivenciado de forma singular por cada sujeito e acompanhado de diversos desafios. Desde os anos 1980, há um crescente interesse no idoso, sendo o envelhecimento saudável ou ativo mundialmente estimulado. Este tem como uma de suas premissas a autonomia. Nas práticas de saúde, contudo, profissionais, idosos e famílias experimentam dificuldades frente aos imprecisos limites entre as exigências técnicas e o respeito ao exercício da autonomia do idoso na produção de respostas às necessidades de saúde identificadas por cada um desses sujeitos. O presente estudo tem como objetivo compreender como a equipe de Saúde da Família e o idoso identificam e lidam com a questão da autonomia no cotidiano do cuidado. De forma específica, objetiva identificar quais são e como são apresentadas as principais facilidades e dificuldades encontradas no tocante à autonomia no cuidado do idoso; compreender quais são as estratégias de enfrentamento das facilidades e dificuldades elencadas e identificar a percepção do idoso em face de seu próprio processo de envelhecimento, cuidado e preservação de sua autonomia. Trata-se de uma investigação qualitativa que utilizou como ferramentas a observação participante $e$ entrevistas semiestruturadas com idosos e profissionais de saúde. A construção e interpretação das narrativas foi orientada por uma perspectiva epistemológica desdobrada da hermenêutica filosófica de Gadamer e da teoria da interpretação de Ricoeur. O quadro teórico do Cuidado e da Vulnerabilidade, tal como proposto por Ayres, orientou a definição das categorias interpretativas. $O$ trabalho de campo foi desenvolvido em uma Unidade Básica de Saúde da região central da cidade de São Paulo durante o ano de 2019. Foram entrevistados 16 profissionais de saúde e 8 idosos. Para além de levantar e discutir uma rica variedade de experiências do envelhecer e dos arranjos e estratégias utilizados pela equipe da atenção básica para o desenvolvimento da atenção ao idoso, o estudo propiciou um novo olhar sobre a questão da autonomia e sua relação com o cuidado em saúde. Estreitamente relacionada às dificuldades, facilidades e estratégias de enfrentamento dos desafios diários da atenção à saúde do idoso, a autonomia mostrou-se um importante marcador de vulnerabilidade (interpessoal, social e programática), indicando áreas que requerem atenção particular, para que objetivos técnicos e sucesso prático possam realmente ser articulados e adequadamente focados nos "projetos de felicidade" dos idosos. Distintamente, porém, de um atributo individual, a autonomia revelou-se a expressão de características relacionais, exigindo estratégias técnicas e horizontes prático-morais plurais e flexíveis, sempre orientados pelo mesmo compromisso ético de respeito às necessidades singulares dos indivíduos. 
Descritores: Envelhecimento; Saúde do idoso; Atenção primária à saúde; Autonomia relacional; Saúde pública; Vulnerabilidade em saúde; Cuidado; Hermenêutica. 


\begin{abstract}
Carneiro JLS. The care of the elderly in primary health care from the perspective of autonomy: a study in a downtown area in the city of São Paulo [dissertation]. São Paulo: "Faculdade de Medicina, Universidade de São Paulo"; 2020.

The proportion of elderly people in the population has been growing in almost the entire globe as a result of increased life expectancy and reduced fertility. Aging is a great accomplishment that modern society, experienced in a unique way for each individual and accompanied by several challenges. Since the 1980s, interest in elderly people has increased with healthy or active aging being stimulated all over the world, adopting autonomy as one of its premises. Yet in health practice, professionals, elderly and families experience difficulties in view of the imprecise limits between technical requirements and respect for the exercise of the elderly's autonomy in producing responses to the health needs identified by each of these subjects. The objective of this study is to understand how the Family Health team and the elderly identifies and deals with the issue of autonomy in daily health care needs. It aims particularly to identify what are the main facilities and difficulties encountered regarding autonomy in elderly care; to understand what are the strategies for coping with these facilities and difficulties and to identify the elderly's perception of their own aging process, care and preservation of their autonomy. It is a qualitative study based on participant observation and semi-structured interviews. Narratives construction and interpretation were based on an epistemological perspective derived from Gadamer's philosophical hermeneutics and con the interpretation theory of Ricoeur. The theoretical framework of care and vulnerability, as proposed by Ayres, guided the definition of the interpretive categories. The field study was developed in a Primary Health Care service in a downtown area of the city of São Paulo during 2019. Sixteen health professionals and 8 elderly people were interviewed. After raising and discussing a rich variety of experiences of aging and the arrangements and strategies used by the primary health care team to provide assistance for the elderly, the study has thrown a new light over the issue of autonomy and its relationship with health care. Close related to the difficulties, facilities and coping strategies of the daily health care challenges of the elderly, autonomy showed to be an important vulnerability marker (interpersonal, social and programmatic), indicating areas that require particular attention, so that technical goals and practical success can actually be articulated and adequately focused on the elderly's "happiness projects". Distinctly, though, of an individual attribute, autonomy revealed to be the expression of relational characteristics, demanding plural technical strategies and practical-moral horizons, always driven by the same ethical commitment and respect to the singular contexts and needs of the individuals.
\end{abstract}

Descriptors: Aging; Health of the elderly; Primary health care; Relational autonomy; Public health; Health vulnerability; Care; Hermeneutics. 


\section{SUMÁRIO}

\section{LISTA DE ILUSTRAÇÕES}

\section{LISTA DE ABREVIATURAS E SIGLAS}

\section{RESUMO}

\section{ABSTRACT}

1

INTRODUÇÃO: A MOTIVAÇÃO EM TORNO DO TEMA, O ENVELHECIMENTO, A ATENÇÃO PRIMÁRIA À SAÚDE, A

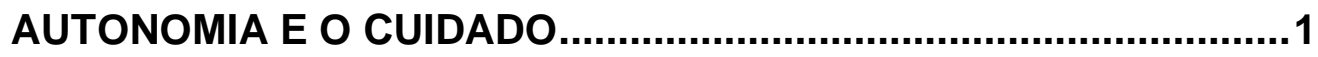

1.1 CASOS E "CAUSOS" - OS DESAFIOS DIÁRIOS 2

1.2 O ENVELHECIMENTO, O SER IDOSO E AS PRÁTICAS E POLÍTICAS DE SAÚDE

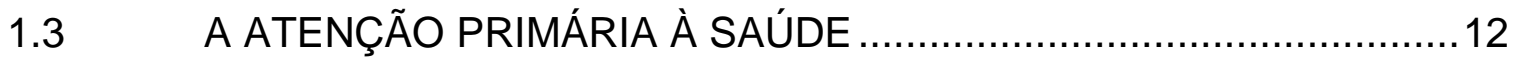

1.4 O ENVELHECIMENTO E A AUTONOMIA …...............................21

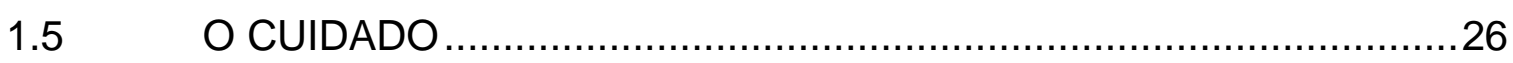

2 OBJETIVOS

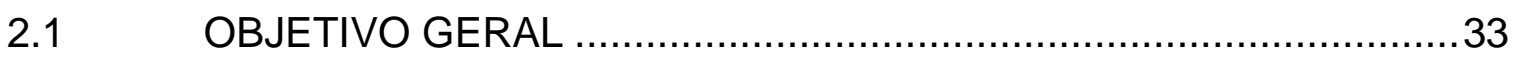

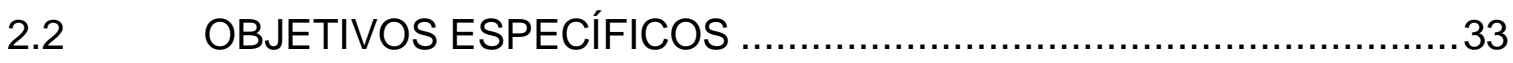

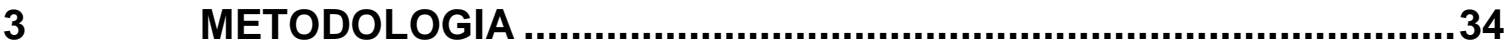

3.1 DESENHO DO ESTUDO E INSTRUMENTOS DE PESQUISA .........34

3.2 A HERMENÊUTICA COMO REFERÊNCIA FILOSÓFICA, BASE EPISTEMOLÓGICA E ESTRATÉGIA DE INTERPRETAÇÃO............39

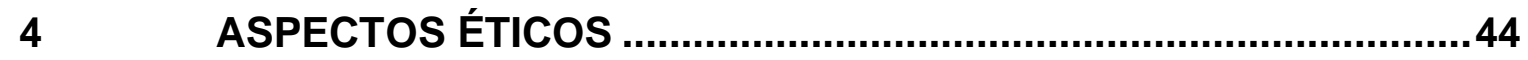

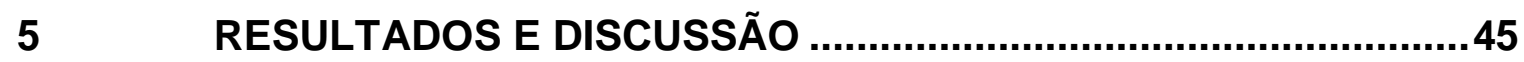

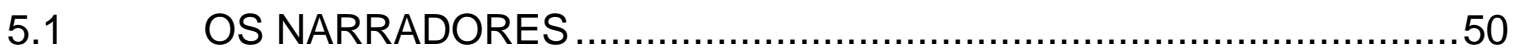

5.1.1 Os narradores "60 mais".............................................................

5.1.2 Os narradores profissionais de saúde ...............................................58

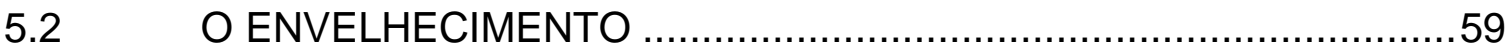

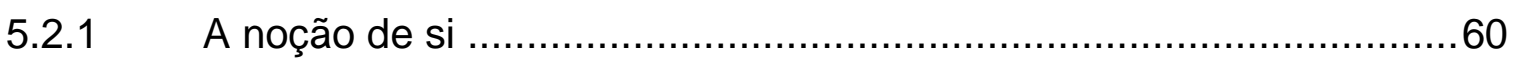

5.2.2 A percepção de envelhecimento pelos profissionais de saúde ..........67 


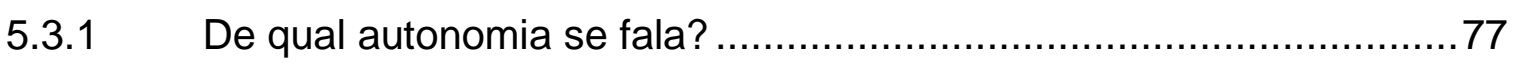

5.3.2 A Autonomia do idoso no cotidiano da Atenção Primária à Saúde .82

5.3.3 Autonomia, cuidado e principais desafios e facilidades da atenção ao idoso na Atenção Primária à Saúde .85

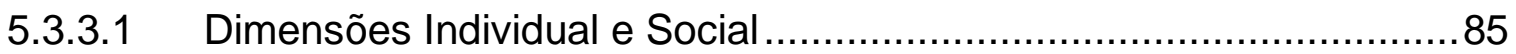

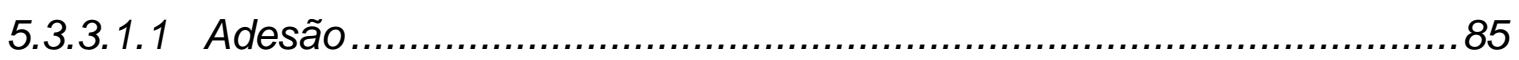

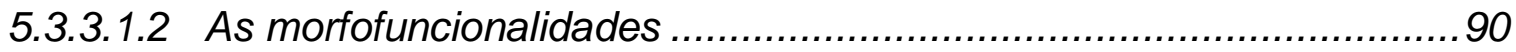

5.3.3.1.3 Dependência, Solidão e Família ..................................................94

5.3.3.1.4 Condição socioeconômica e comunidade......................................110

5.3.3.2 Dimensão Programática .......................................................115

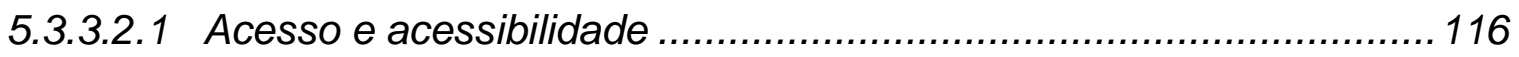

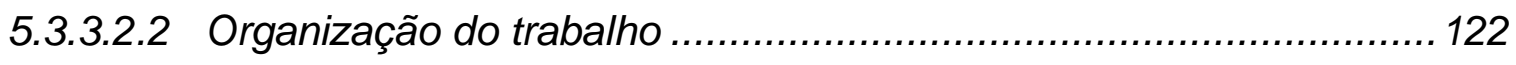

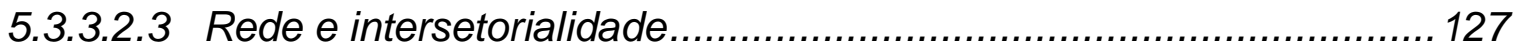

5.3.4 Autonomia, Cuidado e os caminhos trilhados nos desafios da atenção ao idoso na Atenção Primária à Saúde .............................133

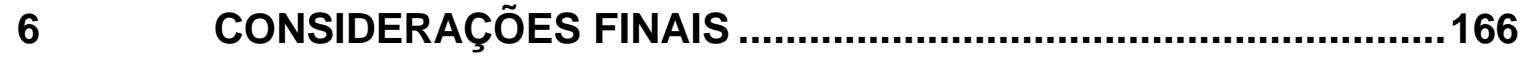

$7 \quad$ ANEXOS

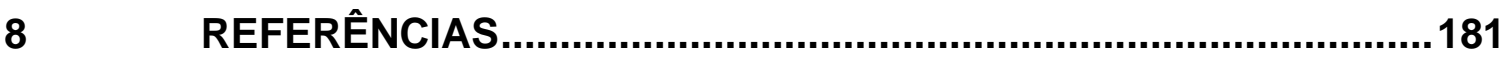




\section{INTRODUÇÃO: A MOTIVAÇÃO EM TORNO DO TEMA, $O$ ENVELHECIMENTO, A ATENÇÃo PRIMÁRIA À SAÚdE, A AUTONOMIA E O CUIDADO}

O meu interesse a respeito da autonomia do indivíduo dentro dos cuidados de saúde se iniciou na época da residência em Medicina de Família e Comunidade na Pontifícia Universidade Católica do Paraná realizada entre os anos de 2011 e 2013. Em dia de grupo para pacientes diabéticos insulinodependentes fizemos uma atividade educativa sobre cuidados com os pés. Durante esta orientação uma senhora se levantou e disse que gostaria de "pendurar os pés" na unidade de saúde, já que fazia tempo que não passava em consulta e seria culpa do serviço caso sofresse algum dos problemas mencionados durante a atividade. Ao término das orientações, a convidamos para conversar e entender melhor suas preocupações. Prontuário acessado junto à paciente e encontramos os registros de faltas em consultas e mesmo de tentativas frustradas de duas visitas domiciliares. Entendemos, os três, paciente, preceptor e eu, que era necessário repactuar o tratamento com tarefas de cuidados para a equipe e para a paciente.

Neste momento o questionamento sobre o papel do indivíduo como protagonista em seu cuidado e a responsabilidade do serviço de saúde começou a fomentar minha curiosidade.

Residência finda e novos desafios se iniciam. Após atuar no interior do estado de São Paulo, passei a trabalhar na região centro-oeste da capital paulista. Neste cenário de prática o desafio recaiu especialmente sobre as dificuldades na assistência ao idoso. Reuniões após reuniões eram trazidos casos instigantes quanto ao cuidado integral de nossa população senil: problemas de ordem financeira, de mobilidade, de acesso, de realizar o autocuidado, de baixa continência familiar, de decisão de morar sozinho mesmo quando o grau de independência física e cognitiva diminuía diante de nossos 
olhos. Agentes comunitárias com expectativas de respostas. Serviço social, psicologia, equipe médica e de enfermagem buscando alguns caminhos. E, como grupo, passamos a ter diversos questionamentos: até onde temos o direito de intervir? Como equilibrar a valorização da autonomia e não intervir de maneira paternal, como muitas vezes ocorre no cuidado diário da atenção primária? Qual o limite da técnica?

Diante da necessidade de compreender melhor estas questões em sua complexidade surgiu o desejo de ingressar no programa de pós-graduação para reflexão sobre esse panorama. Não há o intuito de gerar uma resposta única, em especial porque cada indivíduo, cada família, cada equipe é singular e mutável ao longo do tempo e do espaço e não se pode colocar a individualidade em fluxogramas ou protocolos, mas, sim, de refletir sobre esse problema e explorar novos horizontes de prática e cuidado.

\subsection{CASOS E "CAUSOS" - OS DESAFIOS DIÁRIOS}

"Ninguém começa a ler a palavra porque antes o que a gente tem para ler à disposição da gente é o mundo" - Paulo Freire no documentário Paulo Freire Contemporâneo

Cada parágrafo a seguir relata um caso real de atendimento, apresentando algumas cores da realidade desafiadora do cuidado ao idoso na Atenção Primária à Saúde (APS).

Reunião de equipe, a agente comunitária de saúde (ACS) Cláudia ${ }^{1}$ nos apresenta o caso da Dona Alice, 89 anos. Aposentada, após trabalhar muitos anos como professora, Alice atualmente vive em um quarto de pensão, sozinha. Devido à multimorbidade e limitação de mobilidade, possui autocuidado precário, o que pode ser notado ao entrar em sua residência. Realiza sua principal refeição, o almoço, no bar próximo à sua casa, auxiliada pelo dono do bar e sua esposa. Como família, Alice possui apenas um irmão, também idoso, e uma

\footnotetext{
${ }^{1}$ Todos os nomes próprios utilizados neste relato e nos seguintes são fictícios.
} 
sobrinha. Iniciamos a abordagem ao caso. Entendeu-se ser necessário articular a rede familiar, com a anuência de Alice. Na mesma semana, justamente naquela da realização do contato, o irmão dela falece. Na semana seguinte, o esposo de sua sobrinha (filha do irmão falecido) também morre. Em respeito ao período de luto e desejo da sobrinha, concedemos uma pausa temporária nas conversas. Alice, por sua vez, recebe a oferta de morar na casa paroquial, com apoio esporádico da comunidade na qual congrega. Não possuirá geladeira ou fogão. Seu quarto, ao menos bem limpo, contará com cama, guarda-roupa, uma mesa e o banheiro. A sobrinha consegue alguém que possa ir 3 vezes ao dia auxiliar na troca das fraldas. O dono do bar continua levando o almoço para Alice. Apesar de entender que o que possui é aquém daquilo que necessita para seu efetivo cuidado, Alice prefere ficar na casa paroquial. "Não quero incomodar ninguém". Não possui a chave para entrar ou sair de seu quarto.

Nova área adscrita à unidade. O porteiro, Geraldo, solicitou cadastro e intervenção para duas moradoras do prédio. Está muito angustiado por entender que as senhoras estão incapazes de coordenar seu próprio cuidado. Cadastro oferecido, aceito e realizado, é hora da apresentação na reunião de equipe. Flávia, a agente comunitária, nos traz com mais riqueza de detalhes a história de duas irmãs: Ana e Beatriz. Esta deambula com andador, após múltiplas fraturas de vértebras secundárias a um quadro de osteoporose grave. Aquela era sua cuidadora, mas há cerca de 6 meses está acamada e confusa. $O$ diagnóstico ainda não havia sido fechado, porém, após a primeira visita domiciliar, aplicação de questionários específicos, exames laboratoriais e de imagem concluímos: demência vascular. Professora de inglês e botânica aposentada, uma é exnamorada de um ex-presidente do Brasil, a outra poliglota... nas palavras de Beatriz "condessas decadentes". Investem parte grande de seu orçamento para pagar o atendimento da saúde suplementar e não desejam "incomodar" a família. Não tiveram filhos, possuem apenas um sobrinho mais próximo. Este, atualmente desempregado, com uma filha recém-nascida e a esposa em tratamento por uma depressão pós-parto, tem seu escopo de ações mais limitado. A angústia do porteiro é incorporada aos sentimentos de impotência da agente comunitária. 
Izabel apresenta-se em consulta ambulatorial muito confusa. Não recorda as medicações que utiliza nem suas morbidades e apresenta um discurso repetitivo. Hoje está acompanhada de sua irmã que refere que "Izabel está meio esquecida". Mini Exame do Estado Mental (MEEM) de 18². Agendamos uma visita domiciliar para uma avaliação mais global. Duas semanas depois, no período da manhã encontramos Izabel de pijama, em condições limitadas de higiene, bem como sua casa, comendo um macarrão requentado. "Que horas são agora, dona Izabel?", "Umas três da tarde, eu acho". Banheiro sem luz. Alimentos na pia. Medicações em uma mochila. Izabel fala algumas palavras em russo, recita versículos bíblicos e os horários de todos os cultos que frequenta. Mas refere que entraram em sua casa e levaram suas revistas, erra o dia, o ano, a hora, a frase, o comando... Explico que seu cuidado está limitado em sua casa e Izabel concorda que podemos conversar com a família dela, mas não quer sair dali. Reunião familiar realizada, encontramos conflitos importantes. A sobrinha diz que o caso é grave, que Izabel não pode ficar sozinha, mas que não pode ajudar, pois, tem uma filha pequena. Uma das irmãs diz estar muito chateada por questões financeiras antigas da família e logo uma discussão é travada. Mas no saldo, uma das irmãs decide que vai morar com Izabel... o que dura pouco tempo. Hoje Izabel está sozinha novamente, não quer sair de onde mora.

Joana, 85 anos, com quadro demencial moderado, impactando já em algumas atividades de vida diária e várias das instrumentais. Sua filha deseja que a idosa se mude para sua casa. Joana não quer. A filha oferece para morar com Joana. Esta não quer atrapalhar, em suas palavras, a vida da filha que é casada e possui filhos. Em todas as consultas, nos últimos 2 anos, a senhora diz que irá se mudar para Itapevi. Pactuamos que Joana deixará sua filha coordenar as medicações, consultas e a visitar com frequência (a filha deseja diariamente, mas Joana só aceita 3 vezes por semana).

\footnotetext{
${ }^{2}$ Mini Exame do Estado Mental ou Minimental é um teste realizado para rastreio das funções cognitivas (orientação temporal e espacial, memória imediata e de evocação, cálculo, linguagemnomeação, repetição, compreensão, escrita e praxia). A pontuação mínima esperada varia conforme a escolaridade. Abaixo dessa pontuação, é considerado como alterado e sugere necessidade de investigação para alterações cognitivas, como nas demências. Segundo Brucki e Cols, 2003, os valores de corte para sujeitos de 65 anos ou mais são: 18 (analfabetos), 24 (1 a 4 anos de escolaridade), 26 (5 a 8 anos de escolaridade), 28 ( 9 anos ou mais de escolaridade).
} 
Luiz, 60 anos, antigo conhecido dos funcionários da Unidade Básica de Saúde foi cadastrado na equipe de Saúde da Família. Tempos depois diagnosticado com diabetes. Muitas faltas em consultas e em grupos. Várias visitas e convocações, mas equipe com dificuldade em pactuar as ações. Realizada visita domiciliar, entendida a vulnerabilidade social, mas também o bom recurso de apoio com a família. Luiz tinha dificuldade em auto-administrar as medicações e a insulina, que precisou utilizar, mas podia contar com a filha e a esposa, apesar do histórico por elas relatada de violência moral. Mesmo assim, chorava ao pensar em realizar aferições da glicemia. Veio a amputação do membro inferior, depois o acidente vascular cerebral, que limitaram sua mobilidade. Numa tarde, após retornar de uma saída, sentou na cadeira e faleceu. A equipe se pergunta se faltou fazer algo a mais.

Ivone, 80 anos, transtorno psicótico orgânico devido à demência de Alzheimer de início tardio. Por apresentar delírios persecutórios, fica preocupada e ansiosa. Acha que as pessoas têm entrado em seu apartamento, principalmente o porteiro do prédio em que vive. Por conta disso dificulta o contato inclusive com a sua velha conhecida agente comunitária. Celulite de difícil melhora em membro inferior e autocuidado prejudicado, já que não se lembra de tomar os antibióticos e não consegue realizar a higiene necessária. Irrita-se com facilidade e não permite que se continue a realização da avaliação. Sua irmã, com demência de Alzheimer, também é assistida pela equipe. Uma de suas cuidadoras informais e filha, Lúcia, é contatada pela equipe. A família se une e comparece em reunião familiar com a equipe multidisciplinar. Por outros casos no seio familiar e por entender que a família só conseguirá ser continente terceirizando os cuidados, Ivone é levada para uma casa de repouso, seu desejo, contudo, era ficar em sua própria casa.

Rosa, hipertensa e diabética de difícil controle. Após otimização das drogas e o não controle eficaz, é orientada a indicação da insulinização. Rosa não deseja. Tem medo por se lembrar de um familiar que faleceu pouco tempo após iniciar o uso da insulina. Pactuamos, em acordo, reforçar mudança do estilo de vida, uso correto das medicações orais, retornos mais frequentes e, após mais três meses, reavaliar a indicação do uso da insulina. Após uns dois meses Rosa deseja cessar o uso de todas as medicações. "Vou ser curada, não 
quero que meu corpo se acostume com medicamentos". Foi orientada. Médico, auxiliares de enfermagem, enfermeiro. Sua decisão está tomada e a família preocupada.

Pedro, 71 anos, sempre foi um frequentador assíduo das atividades e consultas da Unidade Básica de Saúde. Mas há alguns meses seu comportamento mudou. Antes muito simpático com todos os funcionários. Agora apresentando irritabilidade, alteração da marcha e esquecimento, faltando muito às consultas que agendava. Equipe de Saúde da Família mobilizada a cuidar e investigar segue com matriciamento da saúde mental. Após demora para conseguir exames, excluir alguns problemas e mesmo a necessidade de internação, conclui-se: síndrome demencial. Tentativa de acesso à família frustra. História de abuso emocional e agressividade. A família não se sente em condições de prestar o cuidado.

\subsection{O ENVELHECIMENTO, O SER IDOSO, AS PRÁtICAS E POLÍTICAS DE SAÚDE}

O envelhecimento populacional é um dos maiores acontecimentos da sociedade moderna. Em função da queda da fecundidade e da mortalidade, e consequente aumento da expectativa de vida, praticamente todas as regiões do mundo tem experimentado o crescimento gradual da população de idades mais avançadas (Brasil, 2015, WHO, 2015, UN, 2019). Estima-se que em 2050 cerca de 1.5 bilhão de pessoas no mundo terão 65 anos ou mais, correspondendo a aproximadamente $16 \%$ da população, o que significa que uma em cada 6 pessoas terá 65 anos ou mais (UN, 2019).

Assim como a maior parte do mundo, o Brasil passa pelo processo de envelhecimento, mas de forma rápida e intensa. Segundo Veras (2009) o Brasil é um "jovem país de cabelos brancos". Anualmente 650 mil idosos são incorporados à população brasileira. A expectativa de vida ao nascer aumenta progressivamente e em 2016 a média brasileira era de 75,72 anos. Segundo a Pesquisa Nacional por Amostra de Domicílios Contínua 2012-2019, cerca de $15,7 \%$ da população residente no país é idosa (i.e. 32 milhões de indivíduos), 
demonstrando crescimento de 2,9\% em comparação aos dados de 2012. O contingente denominado como "mais idoso", formado por pessoas com 80 anos ou mais, também apresenta crescimento (Camarano, Kanso e Mello, 2004, Brasil, 2015). Conforme projeções, em 2030, o número de idosos será maior em 2,28 milhões de pessoas que o de crianças e adolescentes entre 0 e 14 anos. Em 2050, os idosos representarão em torno de $40 \%$ da população brasileira, em contrapartida, aos $14 \%$ de crianças (IBGE, Coordenação de Trabalho e Rendimento, 2020; Brasil, 2018).

Ainda que seja uma grande conquista, valendo-se de avanços da tecnologia, da medicina e da nutrição, dentre outros fatores, o envelhecimento também vem acompanhado de vários desafios. A seguridade social, a execução das políticas públicas específicas para idosos e os arranjos familiares atuais (e.g. famílias cada vez menores) são alguns, dentre tantos outros, desafios (ONU, 2007).

A partir deste panorama mundial, desde os anos 80 há um crescente interesse no idoso, sendo mundialmente estimulado o envelhecimento saudável ou ativo. Dentre suas premissas, há o incentivo à autonomia do idoso (WHO, 2015, Brasil, 2006). Na prática, contudo, além da incipiente execução das políticas, o cotidiano assistencial traz, para profissionais, idosos e famílias, ansiedades e dificuldades no exercício dessa autonomia. Situação especialmente agravada em casos de diminuição da capacidade funcional do idoso.

Segundo a Organização Mundial de Saúde (OMS), o idoso é definido como todo indivíduo com 65 anos ou mais, para os países centrais, e 60 anos ou mais, para os países periféricos, assim caracterizados conforme o grau de concentração de riqueza material (WHO, 1984). A idade, contudo, não é um parâmetro absoluto. Em 2002, por exemplo, a própria OMS reforçou que o limite cronológico não é um marcador preciso para as mudanças que acompanham o envelhecimento e que pessoas de mesma idade apresentam estados de saúde, níveis de dependência e participação muito distintos (WHO, 2002).

O envelhecer é tomado de diferentes definições a partir das ciências. Para as ciências sociais, o envelhecimento é uma construção social, cultural e histórica da humanidade, indo muito além do fenômeno orgânico (Lima, 2003). 
Do ponto de vista fenomenológico, "a experiência de envelhecer atua como pressão do passado que cresce, enquanto diminui a possibilidade de futuro", sendo a velhice associada à morte, ao medo, à repulsa e ao sentido de declínio e dependência, a despeito das conhecidas possibilidades de produção presentes na velhice (Burlá, 2014). No campo das ciências humanas, para autores como Debert, Duby, Bordieu e Featherstone "ser jovem ou velho envolve a disputa por espaços de poder entre grupos sociais distintos, em diferentes momentos do curso da vida" (Lima, 2003). Nas ciências biológicas, o envelhecimento habitual, denominado senescência, compreende um processo de alterações funcionais e estruturais que iniciam na terceira década de vida, culminando em progressiva incapacidade para manter o equilíbrio funcional, ou homeostase, em situações de sobrecarga. Embora não implique necessariamente dependência ou incapacidade, está associado, também, a maior prevalência de doenças crônicas e a importantes repercussões no estilo de vida e autocuidado, ainda que haja grande heterogeneidade em diferentes sociedades e culturas, e influências dos diferentes estados socioeconômico, demográfico e epidemiológico dos indivíduos. Já em condições de sobrecarga (como em doenças, acidentes, estresse emocional) pode ocorrer uma condição patológica que necessite de assistência, nesses casos, o envelhecimento passa a ser entendido como senilidade. Desta feita, nas ciências da saúde o envelhecimento é por vezes definido como:

um processo sequencial, individual, acumulativo, irreversível, universal, não patológico, de deterioração de um organismo maduro, próprio a todos os membros de uma espécie, de maneira que o tempo o torne menos capaz de fazer frente ao estresse do meio-ambiente e, portanto, aumente suas possibilidades de morte (Brasil, 2006, p. 8).

Assim, é sabido que o envelhecimento ostenta um caráter heterogêneo, sendo um processo que difere conforme a história de vida de cada indivíduo, numa relação "multidimensional e multirreferencial sob vários aspectos - sociais, culturais, biológicos, psicológicos e ambientais" (Tombini, 2011, p.24). Não, há, portanto, um idoso típico ou uma forma padrão de envelhecer (Duncan, 2013; Franco, 2009; Brasil, 2018; Argota, 2009), nas palavras de Hojaij e Oliveira: 


\begin{abstract}
A velhice faz parte da vida, mas não é uma realidade bem definida. $O$ envelhecer não é um fenômeno linear, é um processo lento e individual, onde a relação com o tempo é vivida diferenciadamente, segundo um maior ou menor grau de deterioração orgânica. Assim, as capacidades funcionais de cada indivíduo são afetadas pela idade biológica e não cronológica, embora a sociedade fundamente suas regras no tempo cronológico. Mas, a velhice tampouco é apenas um fenômeno biológico, ela é permeada de acometimentos de ordem psicossocial e ambiental ao longo da vida, tornando-a mais heterogênea ainda. Dessa forma, podemos dar uma dimensão existencial única para cada indivíduo, onde cada ser experimenta em caráter singular o seu envelhecer (Hojaij; Oliveira, 2015, p.95).
\end{abstract}

Ainda que componente natural da existência humana, o envelhecimento é tanto um ganho coletivo quanto um desafio para a sociedade, em especial ao se avaliar os custos da aposentadoria e da cobertura médico-assistencial (Lima, 2003). A rapidez com que o processo de transição demográfica e epidemiológica se deu no Brasil torna o desafio ainda maior, com repercussões para o sistema de saúde e a sociedade em geral, particularmente pelo contexto nacional de pobreza, desigualdade social e fragilidade das instituições (Veras, 2009). Além disso, é esperado que seja considerada a grande heterogeneidade dos idosos e do processo de envelhecimento. Pessoas de mesma idade possuem variados níveis de dependência, condições de saúde e participação social, por exemplo. Assim, as políticas de saúde precisam considerar esses fatores a fim de que não sejam discriminatórias, como facilmente seriam caso fosse considerado apenas o critério cronológico (WHO, 2002). Portanto, para que o prolongamento da vida seja efetivamente um ganho coletivo, é importante que a sociedade consiga responder com políticas que considerem o idoso na sua integralidade (incluindo capacidade funcional, autonomia, participação social e auto-satisfação), bem como possibilitar a "elaboração de novos significados para a vida na idade avançada" (Veras, 2009, p.549).

No que tange às políticas públicas, a atenção ao idoso começou a ganhar destaque mundial também a partir dos anos 1980, com o surgimento de programas de saúde com propostas de cuidados ampliados, visando a promoção da saúde, a integração social e a manutenção da autonomia. Em 1982 foi convocada a primeira Assembleia Mundial sobre o Envelhecimento pela Organização das Nações Unidas (ONU), em Viena, que traçou as diretrizes do 
Plano de Ação Internacional sobre o Envelhecimento. Nela houve preocupação em sensibilizar os governos para a importância da pauta e fomentar o desenvolvimento de ações nas diversas áreas como saúde, nutrição, proteção de consumidores idosos, habitação, meio ambiente, família e bem estar-social, dentre outras. Em 1991, a Assembleia Geral adotou o Princípio das Nações Unidas em Favor das Pessoas idosas, elencando direitos dos idosos e, em 1992, ocorreu a Conferência Internacional sobre o Envelhecimento com o objetivo de dar o seguimento ao Plano de Ação e adotar a Proclamação do Envelhecimento. Em 2002 foi realizada a Segunda Assembleia Mundial das Nações Unidas sobre o Envelhecimento, em Madrid. O objetivo foi desenvolver uma política internacional para o envelhecimento no século XXI. O grupo adotou a Declaração Política e o Plano de Ação Internacional sobre o Envelhecimento de Madrid. Este, por sua vez, conclama ações para melhoria da saúde e do bem-estar na velhice, com o intuito de atingir alto impacto em países em desenvolvimento. O Plano foi estruturado em três princípios fundamentais: 1) participação dos idosos na sociedade "no desenvolvimento, na força de trabalho e na erradicação da pobreza; 2) promoção da saúde e bem-estar na velhice e 3) criação de um ambiente propício e favorável ao envelhecimento" (Fernandes; Soares, 2012, p.1947).

No final dos anos 90, a Organização Mundial da Saúde (OMS) adotou o documento "Envelhecimento ativo: um marco para a elaboração de políticas", considerado como referência para a abordagem multidimensional e intersetorial. O conceito de envelhecimento ativo é definido então como "o processo de otimizar oportunidades para a saúde, participação e segurança de modo a realçar a qualidade de vida na medida em que as pessoas envelhecem" (WHO, 2002).

Em 2002, a OMS apresentou o "Towards Age-friendly Primary Health Care", um projeto cuja proposta é adaptar os serviços e atender de forma adequada às pessoas idosas, sendo três as áreas de atuação: 1) Informação, educação, comunicação e treinamento (voltados aos profissionais de saúde para qualificar o atendimento), 2) sistema de gestão da assistência de saúde (organização da atenção primária conforme as necessidades dos idosos), 3) 
adequação do ambiente físico, com especial enfoque em acessibilidade (Brasil, 2006).

Em 2015 a OMS lançou o Relatório Mundial sobre Envelhecimento e saúde. Neste, define o envelhecimento saudável como "o processo de desenvolvimento e manutenção da capacidade funcional que permite o bemestar na idade avançada" (WHO, 2015). Como capacidade funcional, entende-se a interação entre a capacidade intrínseca ${ }^{3}$ e o ambiente em que o indivíduo vive para a realização das atividades de sobrevivência e as que considera importantes para si. O documento ressalta a importância de se compreender que, embora a capacidade intrínseca (e assim a funcional) tenda a diminuir com o passar dos anos, são as escolhas ou as diferentes intervenções ao longo da vida que irão determinar a trajetória de cada sujeito. Também identifica como ações prioritárias a quase todos os setores de saúde: o combate à discriminação etária, a preservação do direito de exercer plenamente a autonomia e o apoio ao envelhecimento saudável em todos os níveis e políticas de governo. Este relatório, em associação ao documento da OMS de 2012, continua sendo um norteador para a elaboração de políticas voltadas para o idoso em vários países, incluindo o Brasil.

No Brasil, a Política Nacional do Idoso (PNI) foi promulgada em 1994, lei 8842 de 1994, e regulamentada pelo decreto o 1948 de 3 de julho de 1996 (Brasil, 1996). Antes disso, merecem destaque as ações do Governo Federal nos anos 1970 a partir da criação de benefícios não contributivos (e.g. aposentadorias para trabalhadores rurais e renda mensal vitalícia) e do movimento de desinstitucionalização da velhice, que estimulava a manutenção da independência do idoso e da sua vida na comunidade. Esse movimento se associou à onda de regulamentação das instituições para idosos, como casas de apoio e asilos. A PNI ampliou a assistência ao idoso ao assegurar direitos sociais e ao dispor sobre condições para promover sua autonomia, cidadania e participação na sociedade, além de criar o Conselho Nacional do Idoso. Essa lei estabeleceu a idade de 60 anos para que uma pessoa seja considerada idosa.

\footnotetext{
${ }^{3}$ Como capacidade intrínseca entende-se os recursos físicos e mentais do próprio indivíduo. $\mathrm{Na}$ velhice, cerca de $25 \%$ da capacidade intrínseca se deve a fatores genéticos e $75 \%$ a efeitos acumulados por hábitos de vida e fatores ambientais (OMS, 2015).
} 
Com a regulamentação da lei em 1996, é estabelecida a Política Nacional de Saúde do Idoso (Fernandes, Soares, 2012; Lima 2003; Brasil, 1996), anunciada pela Portaria 1.395/1999 do Ministério da Saúde e posteriormente revogada. Em 2003 foi aprovado no Brasil o Estatuto do idoso, a partir da Lei ํㅜㅅ‥741, que regulamenta os direitos assegurados aos idosos e afirma a responsabilidade do SUS em relação à saúde desta população. Em setembro de 2005, o Ministério da Saúde estabeleceu a Agenda de Compromisso pela Saúde organizada em três eixos: o Pacto em Defesa do Sistema Único de Saúde, o Pacto em Defesa da Vida e o Pacto de Gestão. No pacto em defesa da Vida foram definidas seis prioridades, sendo que três apresentaram impacto para o cuidado da faixa acima dos 60 anos da população: a da saúde do idoso, da promoção à saúde e do fortalecimento da atenção básica.

A Política Nacional de Saúde da Pessoa Idosa (PNSPI) foi, por fim, instituída pela portaria 2528/GM de 19 de outubro de 2006 e é consoante à proposta de envelhecimento saudável da OMS. Ela prevê ações de promoção do envelhecimento ativo e saudável, com estímulo ao desenvolvimento de ações intersetoriais, foco em integralidade da atenção, fomento da participação social, educação continuada e formação de profissionais da saúde do SUS para o cuidado do idoso, dentre outros pontos. Com base nas diretrizes da PNSPI, a atenção primária e, neste caso, a Estratégia Saúde da Família (ESF), é definida como a porta de entrada para do idoso para a atenção à sua saúde, assim como a coordenadora do cuidado em articulação com as redes. Dentro da proposta, a equipe da atenção básica deve captar, acolher, realizar a avaliação global e desenvolver ações voltadas à saúde do idoso considerando tanto sua capacidade funcional quanto as necessidades da comunidade (Costa et al., 2015).

\subsection{A ATENÇÃo PRIMÁRIA À SAÚDE}

A atenção primária à saúde (APS) pode ser entendida como modelo de organização de um sistema de saúde ou um nível de atenção do sistema de saúde (Takeda, 2013). Sob a perspectiva de organização de serviços, a APS se 
configura como espaço para coordenação das respostas às necessidades de indivíduos, suas famílias e comunidade. Segundo a Organização Panamericana de Saúde (OPAS, 2007), tem como valores o direito à saúde, equidade, solidariedade, participação e controle social. Como atributos específicos engloba: primeiro contato (acesso), longitudinalidade, integralidade, coordenação do cuidado, orientação familiar e comunitária, enfoque na pessoa (e não na doença) e competência cultural. Como nível de atenção, a APS é a porta de entrada do sistema com serviços que respondem às necessidades de saúde desde ações preventivas e de promoção à saúde, bem como curativas e de reabilitação, integrando os cuidados e se responsabilizando, ao longo do tempo, pela coordenação do conjunto de respostas às necessidades de saúde (Takeda, 2013, OPAS,2007).

Elaborado pelo Ministério da Saúde do Reino Unido em 1920, o Relatório Dawson é um dos primeiros documentos a mencionar o conceito de APS como organização do sistema de saúde. Ele propunha três níveis principais (centros de saúde primários, secundários e hospitais-escola) e delineava as funções de cada setor e a estruturação do vínculo entre eles. Esse arranjo inspirou a organização dos serviços de saúde em diversos países.

Outro importante marco para a atenção primária remete à conferência realizada na cidade de Alma Ata, em 1978. Nela, princípios da atenção primária instigados na Assembleia Mundial de Saúde (1977) foram debatidos (Lavras, 2011, Starfield,2002). O consenso lá alcançado foi confirmado pela Assembleia Mundial de Saúde, em 1979, e a APS foi definida como:

\footnotetext{
Atenção essencial à saúde baseada em tecnologia e métodos práticos, cientificamente comprovados e socialmente aceitáveis, tornados universalmente acessíveis a indivíduos e famílias na comunidade por meios aceitáveis para eles e a um custo que tanto a comunidade como o país possam arcar em cada estágio de seu desenvolvimento, um espírito de autoconfiança e autodeterminação. É parte integral do sistema de saúde do país, do qual é função central, sendo o enfoque principal do desenvolvimento social e econômico global da comunidade. É o principal nível de contato dos indivíduos, da família e da comunidade com o sistema nacional de saúde, levando a atenção à saúde o mais próximo possível do local onde as pessoas vivem e trabalham, constituindo o primeiro elemento de um processo de atenção continuada à saúde. (OMS, 1978).
} 
No Brasil, outros movimentos também foram fundamentais para explicar a conformação e a importância que a APS possui hoje. Entre os anos de 1920 e 1930 a Saúde Pública apontou os conceitos da higiene privada que pautava a sua ação assistencial na educação sanitária. Baseado nas proposições da higiene privada e na proposta de sua extensão à toda população, em 1924 Geraldo de Paula Souza criou os centros de saúde (Schraiber; MendesGonçalves, 1996) que traziam no seu escopo a educação sanitária e a promoção da saúde. Tais centros foram inovadores porque até o momento as ações de saúde tinham caráter provisório e voltado para controle de doenças epidêmicas. Posteriormente, na década de 1960, outras iniciativas como a da Fundação Serviço Especial de Saúde Pública (atuação maior nas regiões Norte, Nordeste e Centro-Oeste) e das Secretarias de Estado da Saúde também agiram em prol da reorganização dos serviços médicos e desenvolvimento da saúde pública (Lavras, 2011).

Já nos anos de 1950, sob influência do modelo da História Natural das Doenças de Leavell e Clark, foram reformuladas as questões de higiene e educação sanitária. Emergia, então, a proposta da Medicina Preventiva como disciplina científica que trouxe a concepção de ações assistenciais não apenas médico-curativas ou de higiene sanitária, mas sim de abordagem da pessoa como um todo biopsicossocial e a reorientação dos cuidados em um sistema articulado em níveis (primário, secundário e terciário) considerando as complexidades pré-patológicas, patológicas e assistenciais. A partir daí tem-se a noção de uma assistência integral, com ações articuladas de promoção, prevenção, recuperação e reabilitação da saúde e de níveis de intervenção ou seja, de um sistema hierarquizado. Baseados nessas premissas, os movimentos de Medicina Integral e de Medicina Comunitária reelaboraram suas proposições e surgiram as propostas da Reforma Sanitária e da Programação em Saúde (Schraiber; Mendes-Gonçalves, 1996).

Nas décadas entre 1960 e 1970 (principalmente) foram dados os passos iniciais em prol de uma reforma médico-sanitária centrada num sistema nacional de saúde. As primeiras experiências de medicina comunitária aconteceram em 
alguns municípios brasileiros, como Campinas, Niterói, Londrina, Montes Claros, Pelotas, Joinville, com apoio das Universidades e do movimento de Reforma Sanitária (Lavras, 2011).

Nos anos 80 a atenção primária assume papel central nas políticas de saúde dada a instalação de serviços básicos na rede assistencial da saúde pública e dos serviços de medicina previdenciária (Schraiber; MendesGonçalves, 1996). Também nessa década o Movimento da Reforma Sanitária ganha ainda mais força e discute a crise na saúde e os novos rumos dentre os seguimentos da sociedade brasileira e na $8^{\text {a }}$ Conferência Nacional de Saúde consolida conceitos que seriam bases para o texto constitucional de 1988 e a concepção de um sistema único de saúde forte (Lavras, 2011).

Por outro lado, no final dos anos 70 a programação de saúde implantada em São Paulo ampliou a oferta nos serviços. A assistência médica foi associada às ações já realizadas, como de fiscalização do meio, preservação e controle de doenças e educação em saúde. Esses serviços posteriormente se formularam como Unidades Básicas de Saúde (UBS) e incorporaram outros profissionais da saúde e novas práticas assistenciais, como grupos, vacinação persistente e visita domiciliar, para além da clássica consulta médica. Também partiram com a reorganização do trabalho assistencial que culminou pelo estabelecimento de equipes multiprofissionais relacionadas à resolutividade da APS (Schraiber; Mendes-Gonçalves, 1996).

Atualmente no Brasil, no âmbito do Sistema Único de Saúde (SUS), a APS se estrutura, dentre outros modelos, na Estratégia Saúde da Família (ESF) que é considerada desde 1994 sua estratégia prioritária de organização. As equipes da Saúde da Família (eSF) são multiprofissionais compostas por agentes comunitários de saúde, auxiliares ou técnicos de enfermagem, enfermeiro, médico e podem ser complementadas por profissionais da saúde bucal (cirurgião-dentista e auxiliar ou técnico em saúde bucal). A eSF é responsável por uma população adscrita de um território e atua idealmente com práticas interdisciplinares. Em 2008 foram criados os Núcleos de Apoio à Saúde da Família que foram posteriormente denominados como Núcleo Ampliado de 
Saúde da Família e Atenção Básica ${ }^{4}$. Os NASF-ABs são equipes de apoio matricial, compostas por profissionais de diferentes áreas de conhecimento que devem atuar de maneira integrada com as equipes de atenção básica e saúde da família. Objetivam aumentar a capacidade resolutiva, compartilhar decisões e apoiar as práticas em saúde nos territórios pelos quais são responsáveis (Takeda, 2013; Brasil, 2006).

O processo de transição demográfica atual impacta o sistema de saúde pela maior prevalência das condições crônico-degenerativas e pelo padrão de morbimortalidade. Esse processo, associado às demais necessidades de saúde da população brasileira, desenha um quadro epidemiológico complexo que exige mudanças dentro da estruturação do SUS. A fragmentação do SUS segundo Lavras (2011) é um dos pontos de fragilidade e repercute no acesso, na continuidade da assistência e na integralidade. Segundo a autora "como sistema de saúde fragmentado, o SUS não dá conta de responder adequadamente às exigências colocadas por esse quadro de necessidades de saúde" (Lavras, 2011, p.871). O modelo das redes de atenção à saúde ${ }^{5}$ (RAS) teve sua implementação facilitada pelo Pacto da Gestão de 2005 e corresponde a uma das respostas propostas a essa situação de fragmentação da atenção.

\begin{abstract}
A RAS caracteriza-se pela formação de relações horizontais entre os pontos de atenção, pela centralidade das necessidades em saúde de uma população, pela responsabilização na atenção contínua e integral, pelo cuidado multiprofissional, pelo compartilhamento de objetivos e compromissos com os resultados sanitários e econômicos. Fundamenta-se na compreensão da atenção primária como primeiro nível de atenção, enfatizando a função resolutiva dos cuidados primários sobre os problemas mais comuns de saúde e a partir do qual se realiza e coordena o cuidado em todos os pontos de atenção (Brasil, 2018, p. 35).
\end{abstract}

\footnotetext{
${ }^{4}$ Pela Portaria no 2436 de 21 de setembro de 2017, foi estabelecida a nova Política Nacional de Atenção Básica. A partir desta portaria o NASF passou a complementar, além das eSF, as de atenção básica, de forma que passou a ser nomeado Núcleo Ampliado de Saúde da Família e Atenção Básica (NASF-AB).

${ }^{5} \mathrm{~A}$ organização da RAS no âmbito do SUS é definida como arranjos de ações e de serviços de saúde, de diferentes densidades tecnológicas, que integradas por meio de sistemas de apoio técnico, logístico e de gestão, buscam garantir a integralidade do cuidado (Brasil 2018).
} 
Em 2018 foi lançado documento pelo Ministério da Saúde para orientar a implementação da Linha de Cuidado para Atenção Integral à Saúde da Pessoa Idosa no SUS. Ele propõe as ações em rede, tendo a APS como o primeiro elemento do processo longitudinal da atenção e como coordenadora do cuidado. As funções da APS dentro da linha de cuidado são essencialmente: resolutividade, organização dos fluxos e contra fluxos dos usuários e responsabilização pela saúde dos pacientes em qualquer ponto da rede em que estejam. Para identificar as necessidades de saúde da pessoa idosa cabe à APS reconhecer, cadastrar, acolher, mapear as necessidades de saúde da sua população, identificar o perfil demográfico, epidemiológico, socioeconômico e a estrutura da RAS presente no território. Essas ações podem ser desempenhadas pelos agentes comunitários de saúde, e pelas equipes Saúde da Família, NASF-AB, consultório na rua e das Unidades Básicas de Saúde. O próximo passo é realizar a avaliação multidimensional do idoso e a partir dela estratificar o perfil de funcionalidade e pactuar o projeto terapêutico singular (PTS). Considerando a funcionalidade ${ }^{6}$, o documento descreve, então, possíveis formas de organizar o cuidado do idoso. A Figura 1 sumariza as ações propostas para o cuidado conforme o perfil do idoso, como autonomia e independência, e a Figura 2 apresenta os diversos serviços da rede intersetorial, existentes para a integralidade da assistência.

\footnotetext{
${ }^{6}$ Funcionalidade, neste contexto, é tida como bem estar relacionado à presença de autonomia e independência, permitindo que o indivíduo cuide de si e gerencie a sua própria vida. A independência, por sua vez, diz respeito a capacidade de realizar algo sem ajuda de outra pessoa. Em se tratando do idoso, a independência é entendida como a habilidade de executar as atividades relacionadas à vida diária. Quando é necessária uma adaptação ou supervisão, fala-se de independência modificada. Autonomia, na linha de cuidado apresentada, é utilizada como a capacidade de decisão e comando do indivíduo sobre suas ações seguindo as suas convicções. Outros conceitos importantes para compreensão da estratificação conforme a funcionalidade são os de Atividades de Vida Diária (AVD) e Dependência. As AVDs compreendem as atividades básicas e instrumentais de vida diária. São consideradas atividades básicas de vida diária (ABVD) as necessárias ao autocuidado (como banhar-se, vestir-se, locomover-se dentro de casa, por exemplo) e as atividades instrumentais de vida diária, as relacionadas ao desenvolvimento pessoal e social, favorecendo a integração do indivíduo ao seu entorno (como preparar as refeições, fazer compras, cuidar das próprias finanças, usar o telefone). Por fim, por dependência entende-se a dificuldade em realizar sem ajuda tarefas básicas para uma vida independente, quer sejam de autocuidado, quer sejam domiciliares.
} 


\section{FOCO DO CUIDADO NA CONSTRUÇÃO DO PTS}

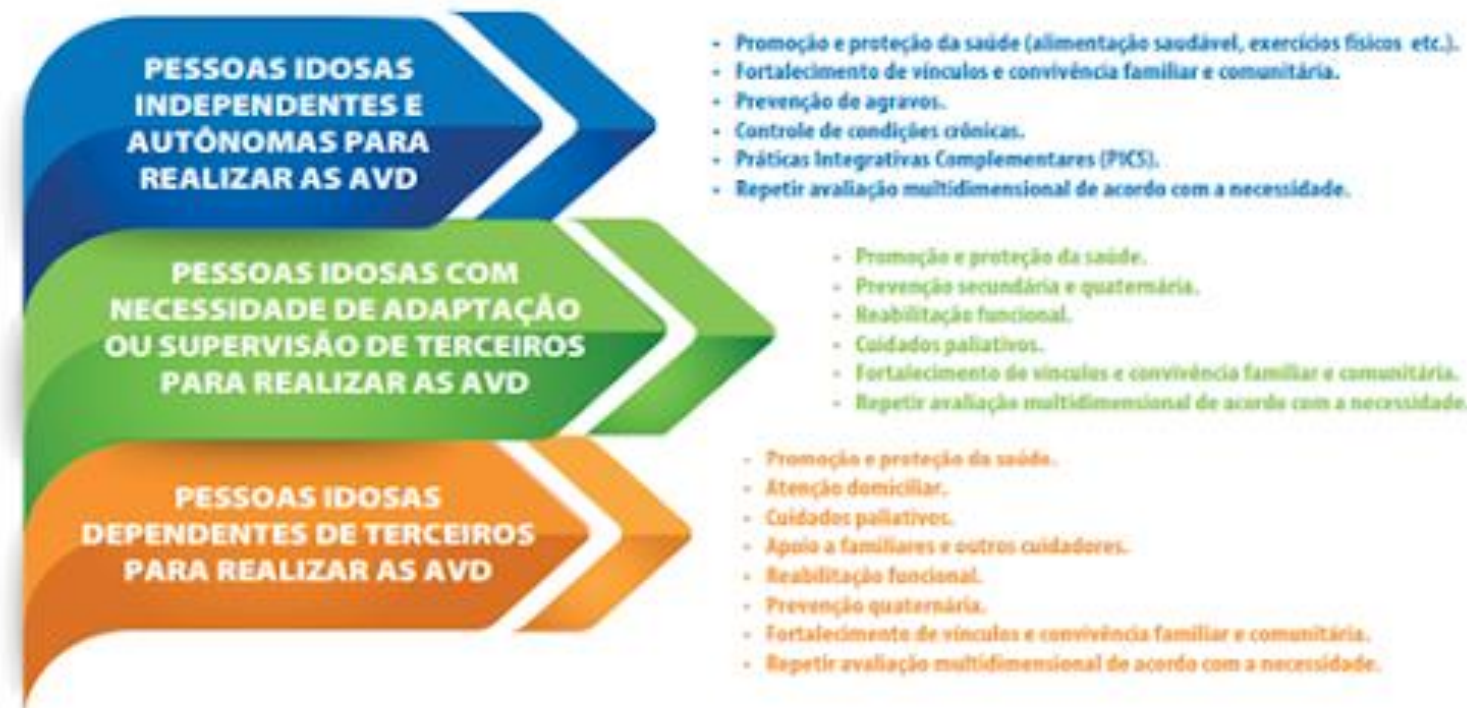

Figura 1 - Sumário das ações propostas conforme o perfil de funcionalidade Fonte: Brasil (2018) 


\section{REDE DE ATENÇÃO INTEGRAL À SAÚDE E REDES INTERSETORIAIS}

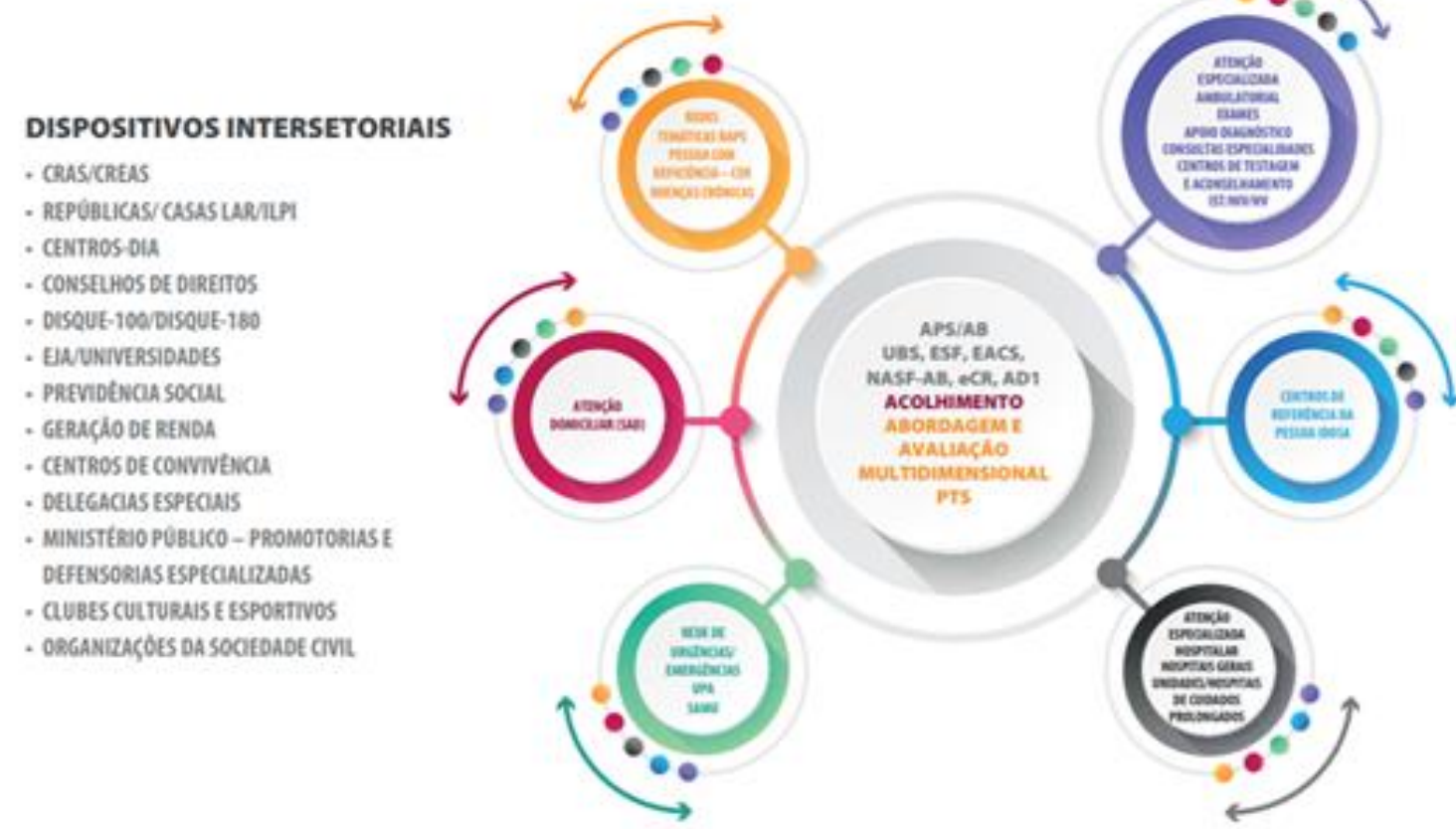

Figura 2 - Dispositivos intersetoriais em articulação em rede para o cuidado do idoso Fonte: Brasil (2018)

A elaboração do PTS privilegia uma co-construção de cuidado que envolve tanto o idoso quanto a equipe de saúde e pode ser uma ferramenta voltada ao cuidado que considere a perspectiva do idoso de um envelhecimento saudável, apoie mudanças de estilo de vida e favoreça práticas no sentido de autocuidado. Considerar o que é o envelhecimento saudável no horizonte do idoso é dialogar com o seu Projeto de Felicidade. Em AYRES (2009b) o termo "projeto" é tomado da filosofia heideggeriana no sentido ontológico-existencial. "Felicidade", por sua vez, é tida como "uma ideia reguladora, isto é, algo pelo qual orientamos nossas decisões, nossas ações, nossas atitudes e que sinalizam que estamos nos movendo conforme nossos projetos" (Ayres, 2009b, p. 19). No construto, entende-se que não se atinge um estado pleno de felicidade, posto que, este projeto de felicidade é um horizonte que se move na mesma medida em que nos movemos para ele. 
A linha de cuidado prevê ainda que:

\begin{abstract}
Em todos os casos, dos mais leves aos mais agravados, o PTS deve considerar 0 desejo e as reais possibilidades de cada sujeito, incorporando o seu histórico clínico, seu contexto familiar, social, econômico, cultural e suas capacidades funcionais. A consideração e o respeito à vontade (decisões, opiniões, valores e crenças) da pessoa idosa são absolutamente fundamentais no planejamento e na efetivação de ações e intervenções em aspectos de sua saúde, de maneira que ela protagonize $\mathrm{o}$ próprio cuidado, aceitando ou recusando tratamentos e intervenções que Ihe forem propostos (Brasil, 2018, p. 32-33).
\end{abstract}

Mesmo que sejam notados vários avanços frente às práticas de cuidados, tanto em termos legais quanto em produção científica, a atenção aos idosos ainda não é a ideal ou mesmo adequada em diversos cenários. Para Assis

Em que se pese o esforço das iniciativas e seus ganhos, há uma
grande distância entre o conjunto de proposições políticas e
institucionais, e a realidade da velhice e da atenção aos idosos,
sobretudo em países periféricos como o Brasil (Assis, 2004, p. 16).

Segundo Araújo, Brito e Barbosa (2008) a falta de recursos humanos especializados para efetivo cumprimento das diretrizes tidas como essenciais (promoção do envelhecimento saudável e conservação da capacidade funcional) e as debilidades na gestão do sistema (em processos de trabalho, normatização excessiva e avaliação quantitativa da produção, em vez de qualitativa, por exemplo) são entraves para a melhor atenção.

Diversos são os desafios pertinentes ao cuidado do idoso na Atenção Primária à Saúde. Identificá-los, tanto por parte da equipe, quanto por parte do idoso e entender as estratégias de enfrentamento são caminhos potentes para práticas de co-construção do cuidado. Ainda mais, entender qual o limite da técnica, respondendo a uma pergunta usual "até aonde tenho o direito de ir como profissional de saúde" torna-se uma necessidade para responder a esses anseios e angústias.

O entendimento deste "direito à saúde", saber até onde se pode ir em uma intervenção, conversa com o conceito de autonomia. 


\subsection{O ENVELHECIMENTO E A AUTONOMIA}

$\mathrm{Na}$ Grécia antiga, berço da tradição ocidental, a concepção de autonomia era associada à organização democrática da Polis, representada pela existência do cidadão livre. A autonomia, tida por alguns autores como relativa, era relacionada diretamente à responsabilização: heróis e homens tinham o poder de escolher, contudo, com o ônus de arcar com as consequências. $\mathrm{Na}$ idade média, por sua vez, o sujeito é conformado pela religiosidade e marcado pela ausência de direitos. Neste contexto, a religião, com caráter controlador e regulador, e não a autonomia, era tida como um valor. Assim, mais do que por autonomia, a idade média se caracterizava pela heteronomia. Durante o Renascimento, a atenção novamente recai sobre o humano e renasce uma visão do sujeito e da autonomia influenciada por leituras do mundo greco-romano clássico (Campos; Campos, 2006). As primeiras publicações conhecidas com o uso do termo autonomia datam de 1693. Derivada dos termos "auto" (próprio) e "nomia" (norma ou regra) foi literalmente traduzida como regras próprias. Contudo, apesar do uso histórico, não há ainda um consenso para o seu significado no contexto do cuidado em saúde (Welford et al., 2012).

Para a ética médica, o respeito pela autonomia é considerado um princípio fundamental. Para a maior parte das pessoas idosas a autonomia e a independência são valorizadas e consideradas como importantes para a boa qualidade de vida (Duarte et al., 2010; Tavares et al., 2017; WHO, 2015; Smebye; Kirkevold; Engedal, 2016).

Atualmente se reconhece que a autonomia envolve dimensões que podem ser compreendidas sob enfoque da política, das ciências, dos poderes ou sobre o próprio indivíduo, dentre outras. Por isso, é possível se falar em diversas autonomias (Brasil, 2018). Segundo o dicionário MICHAELIS, PRIBERAM o termo "autonomia" possui significados como liberdade moral ou intelectual, autodeterminação, independência funcional das partes do organismo ou do organismo inteiro, contudo, em geral, o conceito de liberdade ${ }^{7}$ diverge do de autonomia. Dada a dificuldade em definir a autonomia de uma

\footnotetext{
${ }^{7}$ Liberdade diz respeito à capacidade de agir sem restrições externas ou internas.
} 
forma única, vários autores a determinam a partir do seu antônimo: o paternalismo ${ }^{8}$ (Welford et al., 2012). Grande parte da literatura pertinente ao envelhecimento restringe o conceito de autonomia a uma de suas dimensões, como a física ou a capacidade funcional (Lima, 2003). Em documentos do ministério voltados ao cuidado do idoso, em geral, o significado é tomado como "a capacidade ${ }^{9}$ do indivíduo de decisão e comando sobre as próprias ações, estabelecendo e seguindo as próprias conviç̧ões”(Brasil, 2018, p. 80). Já segundo Cohen e Gobbetti (2004, p. 48), "nenhum indivíduo é totalmente autônomo, pois o limite de sua liberdade se dará no contexto das relações com os mundos externo e interno". Soares e Camargo Junior (2007) também enfatizam a natureza relativa e relacional da autonomia e a julgam inseparável da dependência. Para isso, dentro do processo saúde-doença, os autores sugerem que se deve fortalecer as relações entre pacientes, familiares e profissionais de saúde mais do que reforçar a autodeterminação "pura e simples", já que esses relacionamentos de autonomia e dependência são essenciais para o cuidado e para a saúde. Trazem ainda que "o que é preciso superar é a dimensão autoritária ou paternalista dessas relações e caminhar no sentido de possibilitar a expansão da autonomia à medida que (e na medida em que) avança o processo terapêutico" (Soares; Camargo Junior, 2007, p. 73). O adoecer requer cuidado, seja mediado pelo conhecimento técnico, seja pelo afeto e carinho, sem que, necessariamente, haja diminuição da autonomia. Nesta mesma trajetória, Campos e Campos (2006), além de afirmarem que a autonomia não é absoluta, acrescentam o entendimento de que ela é um processo dinâmico, em que "saúde e autonomia implicam em perdas ou em aquisições sempre gradativas (...) quase como se fossem coeficientes relativos a um padrão do próprio sujeito ou a padrões sociais e históricos estabelecidos" (Campos; Campos, 2006, p. 669-670), em que esses

\footnotetext{
${ }^{8}$ Paternalismo é tido como a substituição intencional da preferência conhecida de uma pessoa, em qual o indivíduo que se sobrepõe justifica a atitude pelo objetivo de beneficiar ou evitar danos à pessoa cuja vontade é superada.

${ }^{9}$ Capacidade e sua relação com a autonomia tem aparecido cada vez mais frequentemente na literatura, especialmente quando relativa a pessoas idosas. Segundo diversos autores, a capacidade é um dos atributos da autonomia. Em diversas situações, a diminuição da capacidade reduz a habilidade de auto-determinação que é um dos fatores determinantes da autonomia e inclusive já foi tida como sua definição.
} 
limites são passíveis de serem tensionados ou mudados. Definem ainda autonomia

Como a capacidade do sujeito lidar com sua rede de dependências. Autonomia poderia ser traduzida, segundo esta concepção, em um processo de co-constituição de uma maior capacidade dos sujeitos compreenderem e agirem sobre si mesmo e sobre o contexto conforme objetivos democraticamente estabelecidos (Campos; Campos, 2006, p. 670).

O exercício da autonomia, assim, se aproxima de uma ética, pois deverá sempre se colocar em situação e envolverá algum juízo de valor. Como consequência, não há uma autonomia pronta a "priori" para todos, nem para qualquer situação, o que faz o entendimento da autonomia e de sua preservação ainda mais complexos. No contexto da relação médico-paciente, assim como nas demais relações sociais, portanto, defender a autonomia implica reconhecer que ambos os sujeitos devem ter espaço e voz no processo, mas que o protagonista do processo terapêutico é o paciente (Soares; Camargo Junior, 2007; Campos; Campos, 2006).

Em uma intersecção entre o idoso e a autonomia, podemos resgatar em Ayres (2009a) a crítica que se faz à concepção tradicional de identidade e ação transformadora. À ideia de que o sujeito é dotado de uma identidade permanente, imutável, Ayres contrapõe a concepção, baseada em Paul Ricoeur, de uma contínua reconstrução das identidades, num sentido relacional, pensando-se mais em termos de intersubjetividade do que em subjetividade. $O$ conceito da ação transformadora, que classicamente alude ao desejo de que o indivíduo se torne o sujeito de sua própria saúde, que seja o produtor ou agente da sua história, é também reconsiderada para ser relacionada a uma dimensão mais profunda em que o indivíduo é partícipe dessa transformação, que se dá sempre em construção conjunta. Temos, então, de forma consoante, o entendimento de uma autonomia relacional, interdependente.

Apesar do reconhecimento do grande valor da autonomia para o bemestar e do incentivo em políticas mundiais para a preservação da autonomia do idoso, Lothian e Philip (2001), em um estudo de revisão extensiva da literatura, 
afirmam que, embora os serviços de saúde devam ter a primazia de preservar a dignidade $^{10}$, a autonomia e minimizar o sofrimento dos pacientes, em muitas situações, no mundo todo, esses objetivos não são atingidos. A dignidade é desafiada principalmente através de interações negativas entre a equipe e os usuários, falta de consideração pela privacidade dos pacientes, uma insensibilidade geral às necessidades e desejos de uma população mais idosa e por um tratamento por vezes indiferente e desrespeitoso por parte da equipe de saúde. A autonomia é ameaçada quando os pacientes (e seus cuidadores) não recebem informações adequadas, prejudicando a possibilidade de compreender adequadamente o seu diagnóstico e fazer escolhas informadas sobre os seus cuidados ou são destituídos de seu poder. Dentre os diversos pontos que podem levar a essa situação de falta de consideração à manutenção da dignidade e da autonomia, o autor expõe a própria visão pessimista por parte do profissional que atende o idoso e a presença de concepções estereotipadas sobre a população mais velha (levando a casos de ações preconceituosas para com os idosos e seus cuidadores). Em casos de grupos étnicos minoritários, a autonomia é ainda mais ameaçada por falta de conhecimento por parte dos médicos, em geral, das particularidades culturais ou de informações na língua materna desses pacientes.

Situação também delicada se dá na articulação da autonomia e o cuidado de idosos de maior fragilidade

Em situações críticas de fragilidade física, psicossocial, espiritual ou
existencial, podemos observar conflitos bioéticos oriundos da perda
não apenas das capacidades funcionais, mas também da autonomia do
paciente. Na falta de autonomia, por exemplo, na demência, o
responsável pelo paciente tomará as decisões por ele. Os conflitos
aparecem na medida em que os valores morais e biográficos do
portador de demência sejam esquecidos, pelo responsável ou
profissional de saúde, em qualquer fase de sua doença. Quando o ser
humano perde sua autonomia, o que fazer para garantir a ele a
realização de suas vontades e direitos inalienáveis? (Hojaij; Oliveira,
2015, p.98).

${ }^{10}$ Embora inter-relacionados, dignidade e autonomia são conceitos ligeiramente diferentes. Dignidade refere-se a um indivíduo que mantém o respeito próprio e é valorizado pelos outros. 
Vê-se, então que, por vezes, a vulnerabilidade condiciona a autonomia na medida em que a falta de confiança, uma doença ou questões pertinentes ao envelhecimento podem originar dúvidas sobre a capacidade (Tavares, 2011) de forma que a fragilidade do indivíduo pode se expressar na relação entre autonomia e vulnerabilidade.

Diante desse panorama, a OMS (2015) coloca a maximização da capacidade intrínseca como principal ação para permitir o exercício da autonomia. Além disso, independente da capacidade funcional, propõe: a promulgação de leis que protejam os direitos dos idosos, apoiem a conscientização e abordem a violação dos direitos; a difusão de tecnologias de apoio e serviços baseados no domicílio e na comunidade; o provimento de mecanismos para tomada de decisões e planejamento avançado de cuidados visando ao maior controle sobre a própria vida (apesar da perda de capacidade) e a criação de oportunidades para aprendizado e crescimento contínuos ao longo da vida.

Considerando a distância do real e do legal, surgem indagações sobre como de fato as equipes de atenção primária realizam o cuidado e lidam com os seus anseios pertinentes à preservação da autonomia do idoso em especial nas situações de fragilidade e maior vulnerabilidade ${ }^{11}$ individual, social e programática, em que as concepções mais generalizadas de saúde e de um bom cuidado podem parecer se contrapor à preservação da autonomia.

\footnotetext{
${ }^{11} \mathrm{O}$ conceito de vulnerabilidade, por Ayres, estabelece um conjunto de características individuais e coletivas relacionadas à maior susceptibilidade de indivíduos e comunidades a um evento $e$, associadamente, menor disponibilidade de recursos para sua proteção. O conceito será aprofundado posteriormente no trabalho, cabendo aqui uma breve explanação. Ayres apresenta 3 dimensões interligadas dentro do quadro da vulnerabilidade: individual, social e programática. A individual concerne a fatores próprios do indivíduo e suas interações interpessoais, que vão desde a condição de saúde, os valores até o modo de vida dessa pessoa. A social diz respeito a aspectos contextuais que estão em relação com a dimensão anterior, como relações de gênero, raciais, acesso à saúde, educação, justiça, cultura, profissão e cidadania, dentre outros. Já a dimensão programática das análises de vulnerabilidade destaca o modo como as instituições atuam como elementos potenciais para redução, reprodução ou aumento de vulnerabilidade dos indivíduos em dadas circunstâncias sociais. A análise das condições de vulnerabilidade é essencial para o planejamento e o desenvolvimento de ações de prevenção, promoção à saúde e construção do cuidado em saúde.
} 


\subsection{O CUIDADO}

Os tempos assistenciais atuais caracterizam-se por um crescimento da técnica e da tecnologia associados a expectativas grandes quanto ao domínio do adoecimento, do sofrimento, das limitações, da promoção de longevidade, da beleza e do bem-estar, dentre outras esferas da vida. Esse desenvolvimento tecnológico, posto que apresente aspectos muito positivos, tem-se demonstrado ainda débil em responder às profundas e multifacetadas necessidades de indivíduos e populações. Schraiber (1997) aponta a crise assistencial vivida. Para a autora, fatores como dificuldade de acesso a serviços e tecnologias para grande parcela da população, "elitização da assistência", burocracia assistencial, falta de individualização e humanização dos cuidados, desmotivação profissional e más condições de trabalho são importantes aspectos ligados à crise. A prática médica atual apresenta-se essencialmente fragmentada, reducionista, centrada no diagnóstico e na cura de doenças, dotada de pobre relação entre profissionais da saúde e usuários e frágil compromisso com o bem-estar. $O$ objetivo central destas práticas encontra-se relacionado, preponderantemente, à busca do êxito técnico que "diz respeito a relações entre meios e fins para o controle do risco ou agravos à saúde, delimitados e conhecidos pela biomedicina" (Ayres, 2009c, Schraiber, 1997). Nessa busca do êxito técnico. Moura (2012) afirma que é frequente o impulsionamento a

Uma certa polarização de saberes com tendência a uma desconexão entre as tecnociências e a sabedoria prática na qual o conhecimento científico (Episteme) e as habilidades técnicas (Technè) tendem a sobrepujar a sabedoria prática (Práxis) ${ }^{12 .}$ (Moura, 2012, p. 18).

O sucesso prático ${ }^{13}$, neste contexto de disjunção dos saberes, assume uma posição de menor positividade na orientação das ações de atenção à saúde.

12 Referência à filosofia aristotélica, que descreve três tipos de saberes: Episteme (o conhecimento científico), Technè (o saber técnico) e Phrónesis (a sabedoria prática).

${ }^{13}$ Segundo Ayres o sucesso prático "diz respeito ao sentido assumido por meios e fins relativos às ações de saúde frente aos valores e interesses atribuídos ao adoecimento e à atenção à saúde por indivíduos e populações" (Ayres, 2007). 
Contudo, o ato de cuidar é mais que a aplicação de técnicas, pois envolve uma dimensão prática (moral, ética, política) que requer o uso de saberes e juízos voltados a situações particulares e demanda a dialética da compreensãointerpretação-aplicação para a fusão de horizontes do usuário e prestador de cuidados, condições imprescindíveis para que o cuidado atinja seus melhores resultados (Ayres, 2008). Para isso se faz necessário que a lógica e a linguagem instrumental e tecnológica dos discursos profissionais interajam e se deixem permear pela lógica e linguagem dos saberes práticos do cotidiano, onde se enraízam os valores e interesses das pessoas no cuidado de sua saúde.

Nesse contexto, o conceito de Cuidado ${ }^{14}$ desenvolvido por Ayres, enseja participar das práticas de saúde de um modo reconstrutivo, de forma a facilitar a identificação dessa desconexão - das tensões do cotidiano das práticas - e subsidiar a construção de itinerários para sua superação. Para isso, Ayres (2004a) propõe o "desenvolvimento de atitudes e espaços de genuíno encontro intersubjetivo, de exercício de uma sabedoria prática para a saúde, apoiados na tecnologia, mas sem deixar de resumir-se a ela a ação em saúde" (Ayres, 2004a, p. 86). O autor evoca a realização de um exercício de cuidado em que haja uma articulação do êxito técnico e do sucesso prático, com certa "permeabilidade do técnico ao não técnico" a vista de uma humanização. Em outras palavras, uma "potencialidade reconciliadora entre as práticas assistenciais e a vida" (Ayres, 2004b) que requer um exercício no qual a sabedoria prática ${ }^{15}$ esteja colocada em articulação com os demais saberes científicos e técnicos (Moura, 2012). Assim Ayres adota o termo Cuidado como:

Designação de uma atenção à saúde imediatamente interessada no sentido existencial da experiência do adoecimento, físico ou mental por conseguinte, também das práticas de promoção, proteção ou recuperação da saúde (Ayres, 2004b, p. 22).

\footnotetext{
${ }^{14}$ Aqui e em frente utilizaremos o termo Cuidado com inicial maiúscula ao referir ao marco conceitual desenvolvido por Ayres, diferenciando do termo iniciado com a minúscula que remete aos procedimentos em saúde.

${ }^{15} \mathrm{O}$ conceito de sabedoria prática deriva da filosofia aristotélica e é ressoado pela hermenêutica filosófica nos dias atuais. Ele remete a um saber conduzir-se diante das questões da práxis vital que não corresponde a modos de fazer conhecidos e controlados a priori, com apoio em conhecimentos científicos e técnicos, mas se desenvolve como uma racionalidade que busca decisões virtuosas, que nasce das práxis e se relaciona com ela na construção compartilhada da Boa Vida.
} 
Aqui cabe observar também a importância do horizonte normativo que se tem em uma interação terapêutica (que pode se dar nos diversos encontros de um usuário com a saúde, como em grupos, consultas individuais e visitas domiciliares, dentre outros). Se o horizonte é o da morfofuncionalidade e seus riscos, a escuta será voltada a dados para o seu controle ou monitorização. Os demais aspectos da vida do sujeito que procura o atendimento serão elementos subsidiários ou, ainda pior, apenas ruídos. Contudo, Ayres (2004b) ressalta que - cuidado a ser desenvolvido no e pelo trabalho deve ser construído na perspectiva da integralidade, isto é, no propósito de cuidar não "de tudo", mas "em um todo", tomando em consideração uma totalidade singularizada na qual as diversas necessidades adquirem sentido prático e inter-relação. A partir do contexto de vida e das singularidades dos projetos de felicidade de cada indivíduo e comunidade, as ações cuidadoras são imbuídas de significado para além da cura de doenças e devem ser capazes de identificar outras necessidades para o trabalho junto e para além dela.

Em "Cuidado e Reconstrução das Práticas de Saúde" Ayres (2004a), examina o cuidado como categoria ontológica, genealógica e crítica. Segundo o autor a hermenêutica realizada nessas três perspectivas possibilita assinalar construções conceituais e experiências humanas que podem favorecer a reconstrução das práticas de saúde e o "enriquecimento dos horizontes de saberes e fazeres em saúde numa perspectiva decididamente interdisciplinar e intersetorial" (Ayres, 2004a, p.73). O artigo referido trata da trajetória da construção do conceito de Cuidado acima apresentado. Tal caminho é aqui apresentado por se tratar do horizonte a ser utilizado na avaliação das práticas com os idosos na atenção primária neste estudo.

Como categoria reconstrutiva na saúde, Ayres designa o Cuidado como

uma compreensão filosófica e uma atitude prática diante do sentido que as ações de saúde adquirem nas diversas situações em que se reclama uma ação terapêutica, isto é, uma interação entre dois ou mais sujeitos visando ao alívio de um sofrimento, ou ao alcance de um bemestar, sempre mediada por saberes especificamente voltados para essa finalidade (Ayres, 2004a, p. 74) 
Partindo do sentido ontológico do cuidar em Ser e Tempo, de Heidegger, (1995) e também explorando a simbologia da alegoria de Higino ${ }^{16}$, Ayres inicia sua aproximação hermenêutica destacando alguns aspectos relevantes para a discussão do cuidado na saúde, os quais dispõem-se como base para a discussão do Cuidado no plano das práticas de saúde. São eles: movimento (como expressão de que a identidade se constrói no e pelo ato de viver), interação, identidade e alteridade (em uma contínua co-construção nas suas inter-relações), plasticidade (possibilidade de transformação que permite a existência), projeto ("projetar-se e, ao mesmo tempo, ser o curador do projeto"), desejo, temporalidade (o sentido de se falar em cuidado se faz na perspectiva do fluxo temporal: passado [uma origem, herança até o agora], presente [o que se dá, o modo como o agora nos interpela] e futuro [a que nos lançamos, o que tratamos de ser para além do agora]), não-causalidade (compreendendo o cuidado no "círculo hermenêutico", no qual parte e todo ganham sentido de forma dependente um do outro) e responsabilidade ("cuidar não é só projetar, é um projetar responsabilizando-se; um projetar porque se responsabiliza").

Como categoria genealógica, Ayres traz a representação do cuidado como "expressão de formas de vida da civilização ocidental", remetendo ao "Cuidado de Si" de Foucault. Este último autor aponta que o ocupar-se consigo é antigo e emerge como uma "tecnologia do si" na "forma de saberes e práticas voltados para a construção do lugar do eu e do outro" nas interações quer do plano público, quer do privado. O cuidado de si torna-se concomitantemente um

\footnotetext{
${ }^{16}$ Certa vez, atravessando um rio, Cuidado viu um pedaço de terra argilosa: cogitando, tomou um pedaço e começou a Ihe dar forma. Enquanto refletia sobre o que criara, interveio Júpiter. $O$ Cuidado pediu-lhe que desse espírito à forma de argila, o que ele fez de bom grado. Como Cuidado quis então dar seu nome ao que tinha dado forma, Júpiter proibiu e exigiu que fosse dado seu nome. Enquanto Cuidado e Júpiter disputavam sobre o nome, surgiu também à terra (tellus) querendo dar o seu nome, uma vez que havia fornecido um pedaço do seu corpo. Os disputantes tomaram Saturno como árbitro. Saturno pronunciou a seguinte decisão, aparentemente equitativa: 'Tu, Júpiter, por teres dado o espírito, deves receber na morte o espírito e tu, terra, por teres dado o corpo, deves receber o corpo. Como, porém foi o Cuidado quem primeiro o formou, ele deve pertencer ao Cuidado enquanto viver. Como, no entanto, sobre o nome há disputa, ele deve se chamar 'homo', pois foi feito de humus (terra)'. (Heidegger, 1995, p.263-4, apud Ayres, 2004a, p.75)
} 
atributo e uma necessidade de todos os homens. Ao ser vinculado também ao labor, o cuidado de si e a medicina passam a ter estreita relação.

Como categoria crítica, a noção de cuidado, segundo Ayres, recupera o movimento que, já no campo específico da saúde, realiza a denúncia do tecnicismo e do caráter individual-privatista dos saberes e práticas da saúde na contemporaneidade.

Partindo dessa tradição crítica, Ayres traz, então, o Cuidado como categoria reconstrutiva, como apresentado anteriormente e expresso, em outras palavras, como "a possibilidade de um diálogo aberto e produtivo entre a tecnociência médica e a construção livre e solidária de uma vida que se quer feliz" (Ayres, 2004a, p. 85). Trata-se de interação terapêutica que use a tecnologia (mas que não se limite por ela) e valorize a sabedoria prática.

Uma prática de atenção à saúde orientada por esse sentido reconstrutivo transparece cheia de desafios, frente aos quais, Ayres destaca três movimentos fundamentais. O primeiro é o "voltar-se à presença do outro". Este se baseia no aprofundamento do saber sobre as pessoas, já desde a escuta das experiências e saberes práticos e cotidianos das pessoas até a ampliação do espectro de saberes científicos utilizados no cuidado, valendo-se mais ativamente das contribuições das ciências humanas para instruir os processos de trabalho e saúde, integrando o sentido mais estrito do manejo instrumental das morfofuncionalidades a tecnologias propiciadoras de interações intersubjetivas mais ricas nesses processos, que Merhy (2000) chama de tecnologias leves ${ }^{17}$. $O$ segundo é "otimizar a interação" criando estruturas organizacionais nos serviços de saúde que reconheçam e otimizem a operação dessas tecnologias leves. Por fim, aponta o desafio de "enriquecer horizontes" das finalidades e processos do trabalho em saúde abrindo-o na perspectiva da interdisciplinaridade, intersetorialidade e da pluralidade dialógica, isto é, da exploração de diferentes formas e espaços de interação entre profissionais e usuários de serviço para

\footnotetext{
${ }^{17}$ Merhy traz a proposta de diferentes planos de conformação e operação de tecnologias para a saúde. Como tecnologias duras, refere-se ao instrumental (materiais, exames, equipamentos) como leve-duras, remete ao conjunto de conhecimentos do profissional (como sobre a clínica), as leves, por fim, são as implicadas na relação entre os sujeitos no encontro terapêutico.
} 
produzir encontros potentes para a saúde - como diferentes linguagens (arte, práticas corporais, práticas integrativas e complementares).

Ayres (2009b) destaca ainda a primazia, para a realização da integralidade do cuidado, do "ouvir, ver e tocar mais e diversamente", do vínculo, da responsabilização e da ética. Ouvir, ver e tocar são consagrados recursos da anamnese e do exame físico na semiologia tradicional da saúde, instrumentos relevantes para o êxito técnico. Vistos na perspectiva do Cuidado, devem ser entendidos também como parte do diálogo, da compreensão das identidades e alteridades e das singularidades dos grupos e pessoas a que se dirigem as ações de atenção à saúde, como forma de aproximar êxito técnico e sucesso prático. Por isso aponta a necessidade de não apenas ouvir, ver e tocar mais, mas, ouvir diversamente (trabalhar com narrativas construídas pelos sujeitos, não apenas suas respostas objetivas às perguntas da anamnese); ver diversamente (atentar para o indizível, as mensagens não expressas em palavras, mas em gestos, atitude, olhares, ao invés de apenas observar sinais físicos, como marcha, postura, coloração de pele e mucosas, ritmo respiratório, etc.); tocar diversamente (não apenas avaliar parâmetros morfofuncionais, com palpação, percussão e ausculta, mas colocar-se em contato com a corporalidade da experiência de saúde e doença daqueles de que buscamos cuidar).

Como vínculo, o autor remete à possibilidade de oportunizar encontros mais ou menos potentes em "favorecer intersubjetividades mais ricas, plurais e produtoras de compartilhamentos" (Ayres, 2009b, p. 20). Traz o vínculo no sentido de dispor de atitudes com a finalidade de tratar os indivíduos efetivamente como sujeitos, acolher, desenvolver a longitudinalidade e promover o envolvimento de todos (profissionais, usuários, comunidade) no processo de cuidado. Ayres ainda afirma:

Quando nos damos conta da ipseidade de nossas identidades subjetivas, isto é, do caráter substantivamente intersubjetivo, relacional da construção e expressão de nossas identidades, então somos levados a pensar de forma mais consequente a qualidade dos encontros que estamos efetivamente promovendo nos espaços de atenção à saúde. As condições em que promovemos os encontros entre profissionais e destinatários das ações de saúde, já desde o plano macro em que se formulam políticas e modelos de atenção à saúde até o plano micro dos encontros interpessoais, nos espaços 
assistenciais, são diretamente responsáveis pela expressão de nossas subjetividades (Ayres, 2009b, p. 19-20).

A responsabilização é entendida como um acordo tácito entre usuário e profissional, decorrente do vínculo entre eles estabelecido e tem um compromisso central com a resolutividade. Essa responsabilização mútua requer a substituição do "mito da competência técnica absoluta, pela ideia mais concreta e situada da sabedoria. A sabedoria no cuidar não prescinde da competência técnica, ao contrário, beneficia-se profundamente dela" (Ayres, 2009b, p. 20), mas caminha para além dela, no sentido de reavaliá-la continuamente à luz do valor e efetividade práticos das ações. Sob essa ótica, ressignifica também a ideia de eficácia e adesão. A primeira, tendo por horizonte os projetos de felicidade daqueles de quem cuidamos, se dá no "sentido de ser aquilo que melhor realiza o sucesso prático desejado". A adesão, muito facilmente tida como sinônimo de obediência, só pode ser atingida a partir da "aproximação de nossas tecnologias ao que é de fato conveniente para os sujeitos e pode levá-los a, autonomamente, com todas as dificuldades e limites impostos pela "vida real", aderir às suas exigências, às vezes tão penosas".

Por fim, Ayres (2009b) trata da dimensão ética, identificada nas propostas de humanização do cuidado. Estas que apresentam como desafio central uma "ética de emancipação dos sujeitos" desenvolvida pela dignidade do diálogo entre indivíduos plenos de direito. A ética trata de uma dimensão que traz à tona o investimento na autonomia, no diálogo e na decisão compartilhada, buscando a fusão de horizontes de usuário e profissional com base no seu projeto de felicidade, de forma que seja esta a bússola para o atingir um êxito técnico possível para um efetivo sucesso prático.

Conforme o acima exposto, e considerando o lugar estratégico da questão da autonomia na construção da atenção primária à saúde do idoso é que se colocam os objetivos deste projeto 


\section{OBJETIVOS}

\subsection{OBJETIVO GERAL}

Compreender como a equipe multidisciplinar da Estratégia Saúde da Família e o idoso lidam com a autonomia no cotidiano do cuidado na atenção primária à saúde do idoso.

\subsection{OBJETIVOS ESPECÍFICOS}

1. Identificar as principais facilidades e dificuldades encontradas pela equipe multidisciplinar da atenção primária em questões que tocam a autonomia do idoso no dia a dia do cuidado.

2. Identificar como essas facilidades e dificuldades são trazidas em demandas pela equipe (se são identificadas como no campo da autonomia ou em outras esferas do cuidado).

Compreender quais são as estratégias de enfrentamento das facilidades e dificuldades encontradas pelas equipes em relação à autonomia do idoso e o seu cuidado.

3. Identificar a percepção do idoso diante do seu processo de envelhecimento, cuidado e da preservação de sua autonomia. 


\section{METODOLOGIA}

A pesquisa desenvolvida neste trabalho adota o desenho de uma investigação qualitativa sob perspectiva epistemológica desdobrada da hermenêutica filosófica de Gadamer (Gadamer, 2015) e procedimentos compreensivo-interpretativos baseados na proposição de Ricoeur (Ricoeur, 2002; Ricoeur, 1987).

Considerando esse quadro, apresento, a seguir, os aspectos metodológicos da pesquisa e, na sequência, a hermenêutica como referencial teórico-filosófico, postura epistemológica e estratégia interpretativa.

\subsection{DESENHO DO ESTUDO E INSTRUMENTOS DE PESQUISA}

O estudo foi realizado com as equipes de Saúde da família (eSF) de um centro de saúde situado na região centro-oeste da cidade de São Paulo.

Além das ações assistenciais inerentes ao serviço de atenção primária, este centro de saúde $\left(C S^{18}\right)$ realiza atividades de ensino e de pesquisa em tecnologias de atenção primária à saúde, sendo campo de estágio de diversas áreas (enfermagem, fisioterapia, fonoaudiologia e medicina - graduação e residência em medicina de família e comunidade, psiquiatria, clínica médica, ginecologia e pediatria). Esta unidade de saúde possui 3 equipes de saúde da família (compostas por um médico, uma enfermeira, dois auxiliares de enfermagem e seis agentes comunitários e a equipe de saúde bucal) responsáveis por populações bem heterogêneas entre si e conta também com parte da adscrição de clientela com a conformação de Unidade Básica de Saúde tradicional, com clínico, ginecologista e pediatra.

\footnotetext{
${ }^{18}$ O Centro de Saúde em questão será denominado ao longo do texto também como Unidade Básica de Saúde (UBS) ou Unidade de Saúde indistintamente, por se tratar de um mesmo tipo de serviço basicamente, diferenciado apenas pela maior oferta de atividades de ensino.
} 
O desenvolvimento desta investigação busca construir narrativas sobre as diversas significações de cuidado e autonomia na saúde do idoso no ambiente de atenção primária. Para a "co-produção" das narrativas as técnicas escolhidas foram as de entrevista semi-estruturada e de observação participante.

A entrevista semi-estruturada é composta por perguntas abertas e fechadas a partir de um roteiro. Ela permite que o entrevistado discorra sobre 0 tema questionado sem ficar preso à pergunta formulada (Minayo, 2014; Minayo; Assis; Souza, 2016). Por meio dessas entrevistas foram construídos relatos acerca da realização do cuidado ponderado sob o princípio da autonomia, bem como das dificuldades e facilidades vividas tanto pela equipe da atenção primária quanto pelos idosos neste processo, além da percepção sobre o ser idoso e o envelhecimento a partir da perspectiva de todos os depoentes. Os roteiros das entrevistas semi-estruturadas para o idoso e para o profissional de saúde estão disponíveis nos Anexos 1 e 2, respectivamente.

Neste estudo consideramos idosos os indivíduos com 60 anos ou mais, tendo por base a definição da Organização Mundial da Saúde (OMS, 1984). A fim de uma maior heterogeneidade e pluralidade de vivências buscou-se entrevistar idosos:

- Com variação de idade (mais de 60 e mais de 80 anos), sexo, renda, composição familiar (idoso que mora sozinho e com parentes), raça, religião, nacionalidade e situação de moradia (acesso mais fácil ao serviço, favela, apartamento com e sem elevador, por exemplo).

- Relações variadas com o serviço público - que utiliza exclusivamente o SUS e que utilize o SUS e o serviço privado.

- Com perfis diferentes de funcionalidade para fins do cuidado: a) independentes e autônomos para as atividades de vida diária (AVDs), b) com necessidade de adaptação ou supervisão para realizar as atividades de vida diária e c) dependentes de terceiros para realizar as AVDs.

Após aprovação nos comitês de ética, a pesquisa foi apresentada para as eSF nas reuniões de equipe que acontecem diariamente. Na sequência, para a seleção desses idosos utilizou-se um dos seguintes percursos: 
- Indicação por parte dos profissionais das eSFs de idosos que se enquadrassem nos perfis e estivessem dispostos a participar do estudo;

- Convite direto da pesquisadora na sala de espera pelos atendimentos ou após as consultas com alguns dos profissionais das equipes.

Uma vez realizado o convite (diretamente pela pesquisadora ou por um Agente Comunitário de Saúde quando selecionado pela equipe), foi agendada a entrevista no local e horário de escolha do depoente. Todos desejaram que as entrevistas acontecessem em seu domicílio. No dia da entrevista, o ACS da micro-área acompanhou a pesquisadora até o domicílio, a apresentou (nos casos em que o convite veio por parte da equipe) e se ausentou durante a entrevista. Antes da entrevista a pesquisadora informou sobre o trabalho e procedeu junto com o idoso à leitura do Termo de Consentimento Livre e Esclarecido (TCLE), sendo ressaltado ao idoso o anonimato, a não interferência no seu atendimento na UBS, a possibilidade de se desligar do estudo a qualquer momento e o acesso aos resultados do estudo em caso de interesse.

Quanto aos profissionais da eSF, a seleção realizada se propôs a privilegiar variação de idade (mais jovem e mais idoso), tempo dentro do serviço (menor tempo e mais experiência), sexo, nacionalidade e de equipe (captando depoentes de todas as equipes). Inicialmente o objetivo era entrevistar apenas os profissionais das eSF (agentes comunitários de saúde, auxiliares de enfermagem, enfermeiros e médicos de família e comunidade), contudo, dado o grande envolvimento no matriciamento e a frequente referência à assistência social e à geriatria como recursos para o cuidado aos idosos da UBS, dois profissionais dessas áreas também foram entrevistados. Considerando os critérios de seleção, o convite foi realizado diretamente pela pesquisadora aos profissionais. Uma vez aceito o convite, foi agendada a entrevista em local e horário de escolha pelo entrevistado. Todos optaram por realizar a entrevista no próprio CS, sendo que o local dentro do serviço foi variável (consultório, sala de reuniões, espaço de promoção à saúde da fisioterapia), estando sempre presentes apenas a pesquisadora e 0 depoente. Antes da entrevista 0 
profissional também realizou leitura do TCLE com os mesmos procedimentos e cuidados quando com os idosos.

Assim, ao todo foram entrevistados 8 idosos e 16 profissionais de saúde, cujos perfis serão detalhados nos resultados. As entrevistas foram gravadas e transcritas.

A observação participante, por sua vez, é um processo pelo qual o observador se mantém na situação social estudada, observando as pessoas e o contexto em estudo, sendo também, parte desse contexto em observação. É por muitos, considerado um recurso metodológico privilegiado, em especial quando associado às entrevistas. Isso se dá por permitir relações de proximidade entre o pesquisador e a comunidade investigada, explicitar o conhecimento da realidade e do cotidiano nos avaliados, a lógica do serviço e possibilitar uma comparação entre as práticas realizadas e os discursos sobre os processos e situações. Conforme a tipologia de Gold quanto aos papéis assumidos pelo observador em campo, a postura pretendida é a de "observador-como-participante". Nesta, o pesquisador utiliza a observação como estratégia complementar à entrevista (Minayo, 2014). Para a realização da observação participante foram utilizados um roteiro e o diário de campo, no qual foram registradas observações, impressões pessoais, resultados de conversas, mudanças de percepção e o que me tocou durante a vivência no campo (Minayo, 2014; Minayo; Assis; Souza, 2016). Foi privilegiada a observação das interações entre idosos, familiares e profissionais da atenção primária (entre si e com os usuários) ao acompanhar alguns dos atendimentos médicos e de enfermagem ambulatoriais, visitas domiciliares (por agentes comunitários, equipe de enfermagem e médico), grupos, o trajeto do idoso dentro do serviço (recepção, acolhimento, sala de espera), reuniões de equipes e o próprio território em que idosos e serviço de saúde estão inseridos. O roteiro está disponível no Anexo 3.

A observação participante, com registro no diário de campo, e as entrevistas foram realizadas entre dezembro de 2018 e março de 2019 (em maior número após a qualificação do projeto, que se deu em 11 de fevereiro de 2019, já considerando os apontamentos da banca), com um retorno ao campo em setembro de 2019 para construção de novas narrativas com idosos. 
As seguintes temáticas gerais constituíram os principais eixos a partir dos quais o material empírico foi produzido:

1- Caracterização do entrevistado idoso e composição do seu núcleo familiar;

2- Caracterização do entrevistado membro da equipe de atenção primária;

3- Situação atual do idoso, seus projetos de vida (projeto de felicidade) e obstáculos que encontra, sua visão de identidade;

4- Identificação das características dos diálogos nos espaços terapêuticos quanto a co-construção das práticas de saúde;

5- Reconhecimento dos significados de autonomia para os depoentes;

6- Compreensão das principais dificuldades e facilidades encontradas no cuidado em relação à autonomia do idoso;

7- Compreensão dos caminhos percorridos pelos profissionais e idosos para tratar das dificuldades encontradas em relação à autonomia e Cuidado em saúde.

Entre os anos de 2014 e 2016 a pesquisadora atuou na unidade como Médica de Família e Comunidade, de forma a já conhecer parte do território, da rede, da equipe e do contexto. Como veremos adiante em mais detalhes, é reconhecido de que não nos é possível separar os preconceitos que nos impelem a uma determinada perspectiva sobre um fenômeno. A tradição, utilizando o referencial de Gadamer (2015), nos alcança como fruto nas nossas relações, e se faz de plano de fundo das nossas concepções. Ao iniciar a abordagem a algum tema, faz-se então premente explorar a nossa précompreensão e, a partir do percurso de compreensão e interpretação, fazer emergir um novo conhecido, co-construído através de nova fusão de horizontes entre pesquisador e pesquisado. As entrevistas orientam-se, assim, pela ideia de diálogo, como um processo de entendimento na linguagem, por meio de qual se faz, na relação, uma nova compreensão. Não há, portanto, um lugar para a completa neutralidade, ou o não envolvimento. É o engajamento com a nossa própria tradição que possibilita compartilhar novos sentidos encontrados.

O processo interpretativo-compreensivo se deu nas seguintes etapas: 
1- Leitura compreensiva dos depoimentos e dos registros de observação participante, objetivando impregnação, visão de conjunto e apreensão das particularidades;

2- Identificação e problematização dos elementos destacados nos discursos e das ideias presentes;

3- Exploração dos significados apreendidos no encontro entre as preocupações da pesquisadora e as narrativas produzidas, no que se referem à autonomia do idoso e suas implicações para a atenção à saúde na perspectiva do Cuidado e da Vulnerabilidade;

4- Construção de uma síntese interpretativa observando as categorias de análise;

5- Articulação entre objeto de estudo, referencial teórico e material empírico.

\subsection{A HERMENÊUTICA COMO REFERÊNCIA FILOSÓFICA, BASE EPISTEMOLÓGICA E ESTRATÉGIA DE INTERPRETAÇÃO}

Primordialmente definida como "a arte da compreensão e da interpretação", a hermenêutica foi, por muitos anos, tida como um conjunto de procedimentos metodológicos para a compreensão de textos (Moura, 2012). Segundo Ricoeur (2002), a hermenêutica é, originalmente, a teoria das ações da compreensão relacionadas à interpretação do texto. Sob a perspectiva de filósofos e pensadores o conceito foi se ampliando no decorrer dos séculos.

Paul Ricoeur (2002) descreve o desenvolvimento da hermenêutica em três momentos. No primeiro, conhecido como romântico, a hermenêutica caracterizava-se como um método de interpretação de textos clássicos. Chladenius, um dos seus principais representantes, postulava que ao tentar compreender um texto, seria necessário tentar compreender historicamente o espírito do autor. Para Schleiermacher, o propósito da interpretação era a reconstrução da mensagem original do autor e a arte de evitar "mal-entendidos". No segundo período, recebendo a herança romântica que baseava a busca da interpretação na subjetividade e no seu diálogo com o impulso neo-kantiano de buscar o fundamento das diversas áreas de conhecimento objetivo, Dilthey 
atribui à hermenêutica o estatuto de uma epistemologia. Ele vê nos processos de compreensão-interpretação, ou o chamado círculo-hermenêutico, uma base coerente e sólida para o conhecimento dos fenômenos relativos "ao espírito" (as geisteswissenchaften, ou o que chamamos hoje de ciências humanas), em contraste com os métodos aplicados às chamadas ciências da natureza. Em um terceiro momento, construído centralmente pelas obras de Heidegger e Gadamer, a hermenêutica deixa de ser entendida apenas como uma forma de conhecer o humano e passa a ser vista como uma característica constitutiva do próprio modo de existir humano. Nesse sentido, a hermenêutica não é mais entendida como um método, nem como uma epistemologia, mas como uma ontologia, uma perspectiva filosófica sobre a existência na qual se baseiam epistemologias e métodos (especialmente aqueles que tomam o humano diretamente como tema de investigação).

Para Gadamer, a hermenêutica é a busca da compreensão de sentido que se dá na comunicação, tendo na linguagem o seu núcleo central. Ela é entendida como um modo de participar do mundo e está fundada em nosso próprio ser antes que só em nossa vida mental, de forma que para Gadamer "nós somos diálogos". O objetivo primordial de sua obra foi o de elucidar a experiência hermenêutica da verdade, contextualizando nos traços dessa experiência o sentido e alcance dos procedimentos metodológicos das ciências. Sua hermenêutica filosófica alude, então, ao interesse nas questões de conhecimento humano em geral e, em particular, do conhecimento sobre o humano (Ayres, 2008).

A fusão de horizontes é, para Gadamer, o elemento fundamental da hermenêutica. Segundo ele, o entendimento intersubjetivo ocorre quando $o$ horizonte de um e de outro indivíduo se fundem e se expandem, de forma a dialogarem, sem se anularem ou se substituírem (Gadamer, 2015; Ayres, 2008; Pinheiro, 2015). Este aspecto possui importância tanto como um procedimento quanto como um indicador da verdade. Como procedimento, a fusão de horizontes se dá por meio do movimento da participação ativa em um diálogo (entendido como uma dialética de pergunta e resposta - nos conduzimos e somos conduzidos pelo diálogo e este tanto nos pertence quanto nós pertencemos a ele). Como validador, a fusão de horizontes nos aproxima da 
verdade em cada encontro ao nos levar ao entendimento efetivo de algo à medida que mais entramos em contato com o outro, mesmo que sem a obrigatoriedade de concordar. Como consequência desse movimento, Ayres afirma que a) a verdade prática é uma experiência sempre em curso, ilimitada e aberta a ressignificação, b) quando buscamos ativamente nos colocar em contato com outro horizonte, buscando responder a algo que visualizamos desde o nosso próprio horizonte, é quando podemos compreender a mim e ao outro e c) o conhecimento hermenêutico se produz por meio da fusão desses horizontes. A experiência hermenêutica será tanto mais significativa quanto mais ativa e compartilhada for a fusão de horizontes (Ayres, 2008).

Outro ponto da obra de Gadamer pertinente para esta pesquisa é o entendimento que traz quanto ao juízo prévio que o intérprete já possui. Esses juízos prévios ou pressupostos vêm das tradições nas quais estamos inseridos, que não nos é introjetada, mas é fruto das relações de que participamos. Gadamer não vê nisso algo negativo, mas assinala que o intérprete precisa estar sensível para reconhecer seus próprios preconceitos, limites e colocar-se em uma atitude de abertura para o diferente. A boa interpretação implica num movimento do intérprete na direção daquilo que está em debate e que se quer entender (Gadamer, 2015; Palmer, 2014).

\begin{abstract}
Mas essa receptividade não pressupõe nem uma "neutralidade" com relação à coisa nem tampouco um anulamento de si mesma; implica antes uma destacada apropriação das opiniões prévias e preconceitos pessoais, a fim de que o próprio texto [e, por extensão, qualquer ação humana cujo sentido se busca compreender $]^{19}$ possa apresentar-se em sua alteridade, podendo assim confrontar sua verdade com as opiniões prévias pessoais (Gadamer, 2015 p 358).
\end{abstract}

Esta perspectiva gadameriana não é caracterizada especificamente como uma metodologia para interpretação de dados, não obstante, pode-se entender a hermenêutica filosófica como fundamento de princípios epistemológicos para a investigação qualitativa. Neste caso, o investigador atua como intérprete e o faz ciente do seu pertencimento as tradições diversas, com possíveis efeitos na investigação. Uma vez que é sabido não ser possível assumir uma perspectiva

\footnotetext{
${ }^{19}$ Colchete introduzido pela autora.
} 
totalmente alheia a seus próprios pré-conceitos, é imprescindível ao investigador o cuidado de se auto-perceber e confrontar sua própria herança, sua tradição, com o inesperado que se encontra no processo investigativo (Pinheiro, 2015; Palmer, 2014).

Por fim é pertinente associar a esse quadro à perspectiva de Ricoeur. Esse autor, ao encarar o discurso como realização da linguagem, propõe sua teoria de interpretação de textos e a coloca também como um paradigma aplicável igualmente à interpretação das ações humanas.

Na perspectiva trazida por Ricoeur, o discurso ocorre como evento, mas ao transcender sua situação temporalmente delimitada, através de registros diversos ou tradições orais, realiza-se como significação. Assim, entendido na dialética de evento-significação, um discurso, como um acontecimento dinâmico e temporal, a transmissão das experiências vividas, "é a verdade que acontece, que emerge de um estado oculto, mas que se esquiva a toda a tentativa pretendida de reduzi-la a conceitos e à objetividade" (Palmer, 2014, p 244). A significação, por sua vez, diz respeito ao que possibilita que o discurso seja compreendido e fixado (por meio da escrita). Para Ricoeur

\footnotetext{
A articulação entre esses dois polos ocorre em diferentes níveis: o evento abrange $o$ ato de dizer, o que se faz ao dizer e aquilo que se faz pelo ato de dizer; há um correlato de significação na exteriorização que ocorre em cada um desses atos - em maior medida no primeiro caso e em menor, no último (Pinheiro, 2015, p. 27).
}

Ricoeur ainda segue além. Tomando o sentido como "o que", como o conteúdo ou a semântica da frase, e a referência como o sobre o que, o "acerca de quê" ou, em outras palavras, a realidade, a verdade que o discurso exprime, o autor traz a luz mais uma dialética definidora do discurso: a de sentido e referência (Ricoeur, 1987).

Se a dialética do evento e significação e do sentido e referência se faz essencial à estrutura do discurso, que pode ser entendida tanto na fala quanto na escrita; Ricoeur apresenta de forma correlata a dialética da explicação e compreensão para interpretação do discurso. Traz, assim, novamente o conceito de círculo hermenêutico, porém sem o sentido das polaridades entre compreender e explicar como visto na hermenêutica tradicional. Em Ricoeur, 
explicação e compreensão são entendidas como fases de um único processo, ocorrendo essa dialética num movimento da compreensão (a totalidade de sentido do discurso) para a explicação (estruturação formal e sua relação com a significação dos discursos) e, depois, da explicação de volta à compreensão ("corrigida" e enriquecida pela fusão de horizontes produzida).

No primeiro movimento, a compreensão pode ser entendida como uma conjectura, já que as motivações e condições de produção (de um texto ou de uma ação social) extrapolam (por isso desafiam) nossa possibilidade de compreender. A explicação, neste primeiro movimento, se dá como validação. Não como sinônimo de verificação, mas sim uma "disciplina argumentativa" em que a pré-compreensão vai tendo seus componentes conjecturais validados (ou não) pela verificação lógica e empírica de sua plausibilidade. Por ela, entende-se que "uma interpretação deve não só ser provável, mas mais provável do que outra interpretação". No movimento da explicação para a compreensão, esta retorna em vias de satisfazer "o conceito de apropriação (...) como a resposta a uma espécie de distanciação associada à plena objetivação do texto. A explicação surgirá, pois, como a mediação entre os dois estádios da compreensão" (Ricoeur, 1987, p.86).

A hermenêutica como teoria filosófica da compreensão, de Hans-Georg Gadamer, aliada à hermenêutica como teoria da interpretação, de Paul Ricoeur são, assim, o horizonte que norteia metodologicamente tanto a concepção e o desenho deste estudo como a interpretação do material empírico por ele produzido.

$\mathrm{Na}$ perspectiva que adoto neste trabalho, compreender os discursos implica articulá-los nas polaridades dialéticas da compreensão e da explicação, do sentido e da referência. Desta forma, o sentido do discurso, como totalidade compreensiva, será buscado em seu conteúdo proposicional em conexão com a intenção e com o horizonte do locutor (profissional da saúde e idoso), na perspectiva de que tal sentido não se revela enquanto tal senão no propósito de desvelar um mundo que inclui a realidade do próprio intérprete, no caso, o meu próprio horizonte como pesquisadora. 


\section{ASPECTOS ÉTICOS}

O presente projeto está aprovado no Comitê de Ética em Pesquisa da Faculdade de Medicina da Universidade de São Paulo e da Irmandade da Santa Casa de Misericórdia de São Paulo e os Certificados de Apresentação para Apreciação Ética (CAAE) na Plataforma Brasil são, respectivamente, 90497018.1.0000.0065 e 90497018.1.3001.5479.

Os entrevistados foram informados sobre os motivos da pesquisa, suas implicações, sobre a participação não obrigatória e a possibilidade de interromper a entrevista a qualquer momento que desejassem. Além disso, foram orientados sobre o sigilo das informações prestadas e de que a participação não iria interferir com seu acompanhamento dentro da Unidade Básica de Saúde.

Antes de cada entrevista foi aplicado o Termo de Consentimento Livre e Esclarecido (Anexo 4). 


\section{RESULTADOS E DISCUSSÃO}

A unidade de saúde possui 13.786 usuários adscritos, dos quais 9708 estão vinculados às $3 \mathrm{eSF}$. Aproximadamente $19,7 \%$ da população total atendida no serviço tem mais de 60 anos, proporção acima da média de idosos no município de São Paulo (15,2\%) (Secretaria Municipal de Direitos Humanos e Cidadania, 2019). Considerando os vinculados à ESF, a proporção se mantém em 19,7\% (1918 idosos dentre os 9708 usuários), contudo em porcentagens diferentes entre as áreas. A figura abaixo apresenta a distribuição da população entre as equipes de saúde da família e a estrutura de UBS tradicional (composta por clínico, pediatra e ginecologista) no CS.

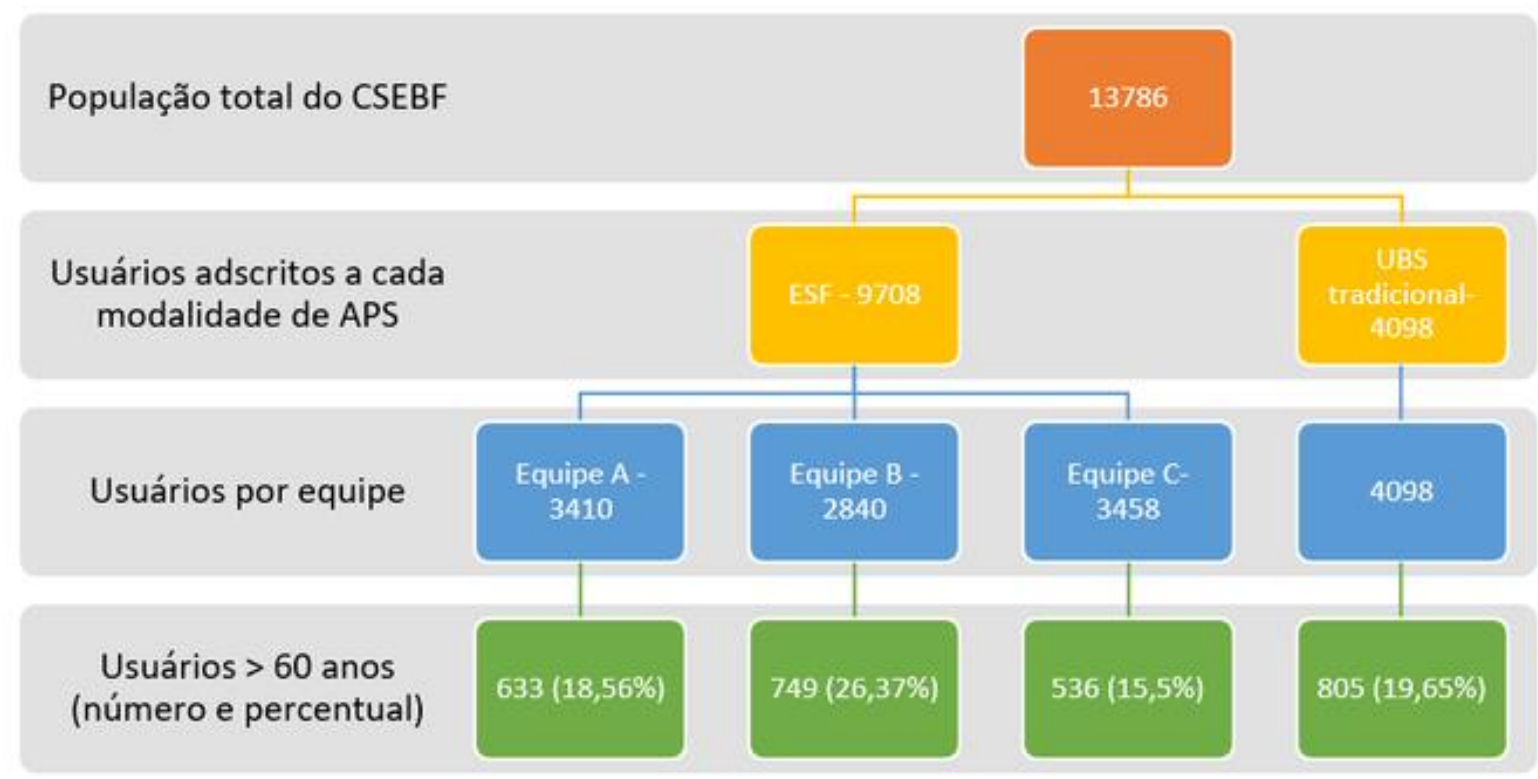

Figura 3 - Usuários do CS - total e por equipe

Fonte: Dados fornecidos pelo CS em maio de 2019

O serviço possui profissionais de diversas áreas da saúde (agentes comunitários de saúde, auxiliares e técnicos de enfermagem, enfermeiros, médicos de família e comunidade, psiquiatras, geriatras, clínicos gerais, pediatras, ginecologistas e obstetras, fisioterapeutas, psicólogos, 
fonoaudiólogos, cirurgiões dentistas, auxiliar de cirurgião dentista, técnico em saúde bucal, assistente social), da limpeza e de administração. Por ser um serviço escola, há rodízio mensal de graduandos e pós-graduandos nas várias áreas acima referidas.

As equipes de saúde da família estavam em fase de mudança do território durante o período do campo, o que explica a variação do número de usuários cadastrados em cada equipe, sendo que a equipe $B^{20}$ estava em fase de adscrição de nova clientela. Conforme informações das ACSs, considerando a territorialização da nova área e os novos registros realizados até aquele momento, havia predomínio de solicitação em maior número de cadastros de pessoas com mais de 60 anos, comparando às demais faixas etárias, o que já era notado no território que já pertencia a equipe, contíguo ao novo.

Cada equipe apresentava um perfil diferente de população e de características do território, conforme relatos dos profissionais e mesmo a observação do campo.

O território da equipe A é o mais próximo em termos de distância do CS. Segundo seus profissionais, a característica mais marcante é a presença de oficinas de costuras e migrantes bolivianos, ainda que tenha também muitas crianças e idosos, além de um território de ocupação. Tem como recursos mais utilizados pela equipe o Centro Esportivo Raul Tabajara, o Centro Comunitário da Legião da Boa Vontade e o Abrigo Boracéia, além das escolas da região. Ainda que próxima do estabelecimento de saúde, o acesso depende da travessia de importante avenida que dispõe de semáforo para pedestres que, segundo usuários e funcionários, disponibiliza tempo muito curto para a travessia. A imagem abaixo foi fornecida por um membro da equipe como sendo uma das que mais caracteriza o território segundo seu olhar.

\footnotetext{
${ }^{20} \mathrm{~A}$ denominação das equipes foi trocada por letras para respeito ao sigilo.
} 


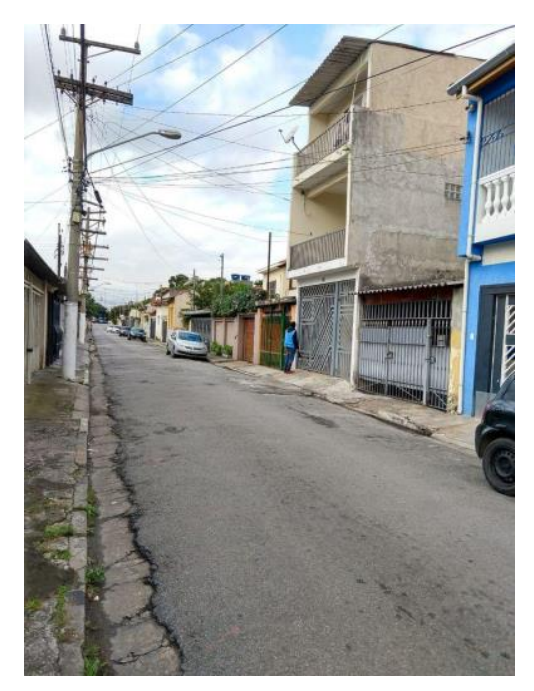

Figura 4 - Território - Equipe A

Fonte: Fornecido por ACS, reproduzido com autorização

A equipe $B$ se caracteriza, pelos seus profissionais, como a que mais atende a idosos, sendo recorrente a discussão de diversos casos dos seus usuários com mais de 60 anos nas reuniões de equipe (incluindo as de matriciamento com saúde mental e serviço social). O acesso da população ao CS depende da passagem por um viaduto (que apresenta apenas estreita passagem para os pedestres, sem barreiras de contenção, como um pequeno muro), de forma que muitos dependem do transporte público ou pessoal para participar dos atendimentos ou atividades oferecidos na UBS. Seu território ainda está em expansão, conforme novas distribuições da prefeitura. O recurso mais utilizado do território é o Parque da Água Branca. Pelas dificuldades de acesso e pelo maior número de idosos, a equipe desenvolve uma atividade chamada "Saúde no Quintal", destinada particularmente aos idosos, na qual, duas vezes por mês, alguns profissionais da eSF e da equipe multidisciplinar (como fisioterapeuta) vão até um dos edifícios no território e realizam atividades na área comum, a fim de desenvolver ações de promoção à saúde, incluindo maior socialização dos moradores do prédio $^{21}$. As imagens abaixo foram

\footnotetext{
${ }^{21}$ Atividade no total tem duração de cerca de 1 hora e meia. Apesar de ser realizada na área comum de um edifício, é aberta a moradores de outros prédios ou casas da região, sendo
} 
selecionadas por um dos profissionais da equipe como sendo as que mais caracterizam o território em seu ponto de vista.

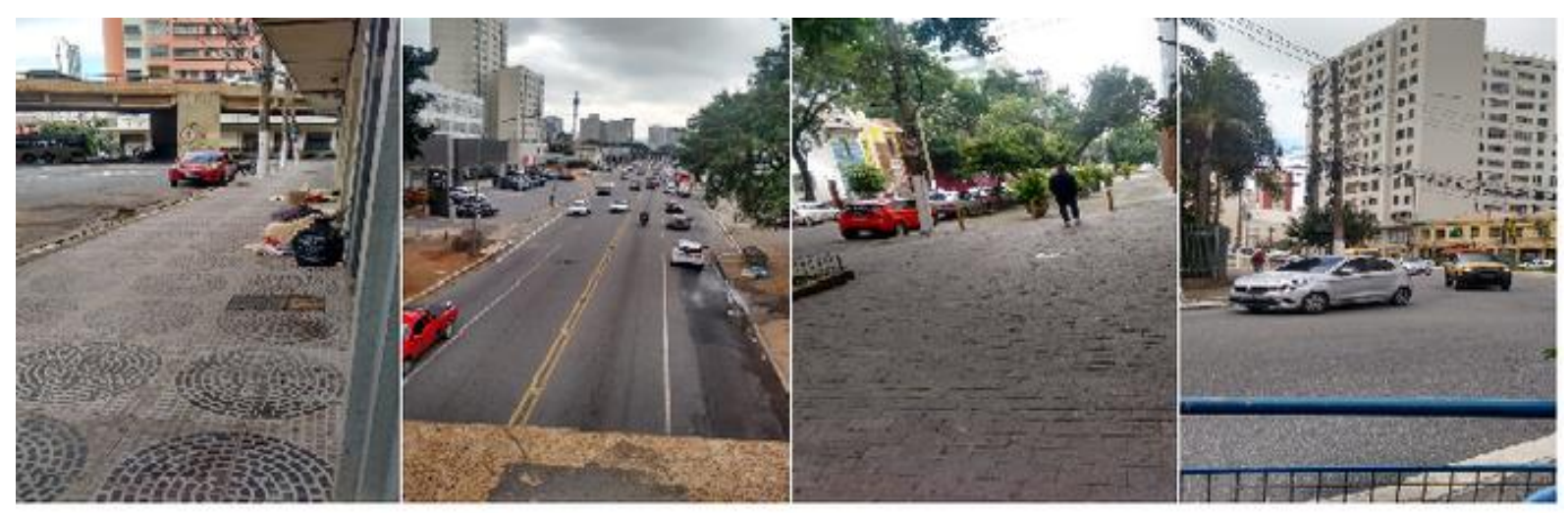

Figura 5 - Território - Equipe B

Fonte: Fornecido por ACS, reproduzido com autorização

Os profissionais da Equipe $\mathrm{C}$, em geral, destacaram a comunidade como área de maior representatividade do território. A mesma situa-se distante do CS, mas a maior demanda em termos de complexidade de atendimento na esfera social advém da região. A distância se configura como uma das dificuldades no atendimento, pois os usuários dependem de transporte público ou privado para ir à UBS. O território está em remodelação e parte dos usuários adscritos na equipe $B$ estão sendo transferidos para o da equipe C. Esta passou, ainda, por alterações na composição da equipe, com agentes comunitários mais novos e, durante o campo, saída da médica. O principal recurso utilizado na comunidade é a escola de educação infantil. As imagens abaixo foram fornecidas pela enfermeira da área. As atividades em destaque são pertinentes ao trabalho contra abuso infantil desenvolvido pela equipe e foram apresentadas como um dos motivos de maior realização profissional para o grupo.

apenas necessário o aviso na portaria ou ser trazido por um dos Agentes Comunitários de Saúde. 


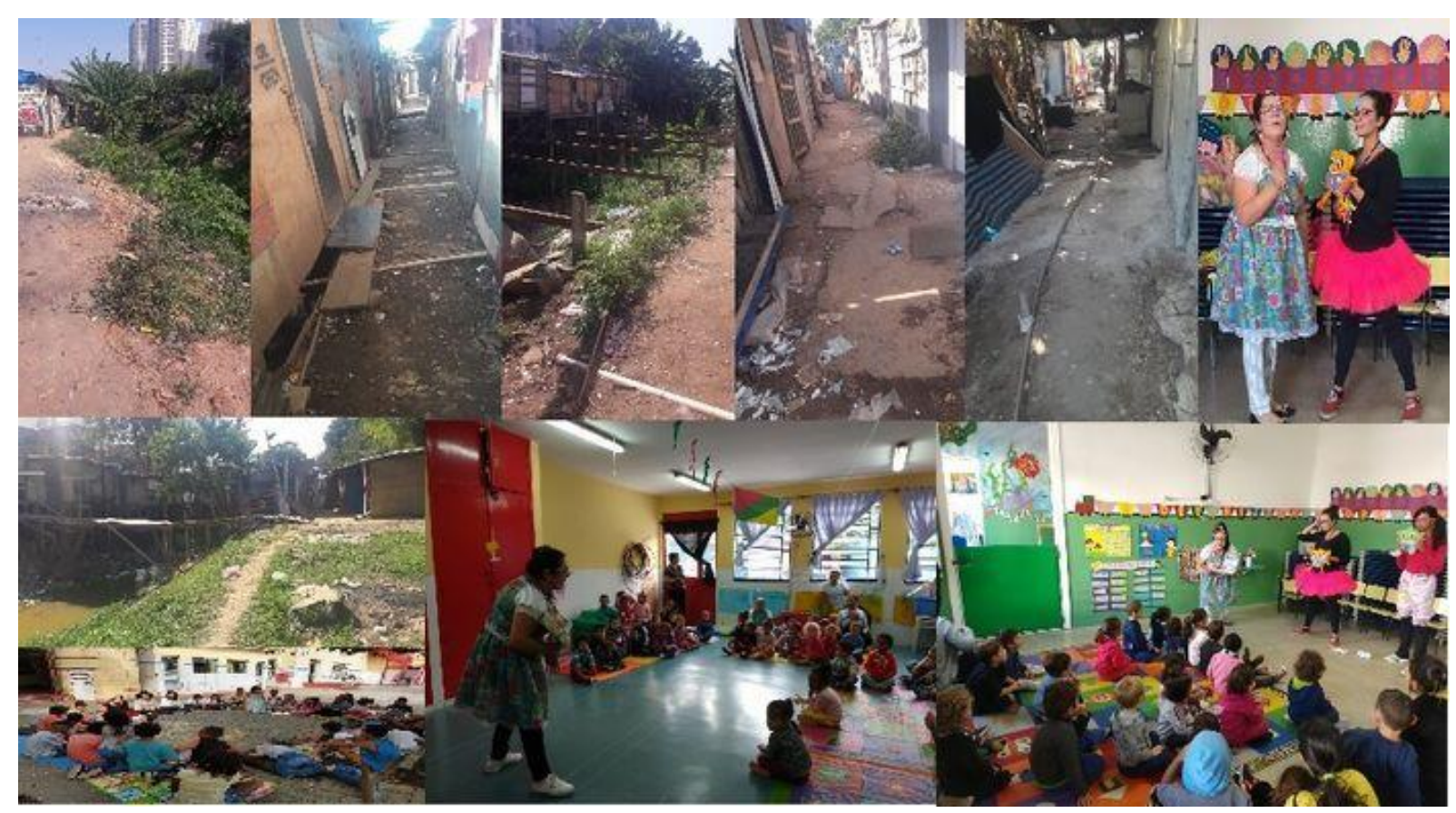

Figura 6 - Território - Equipe $\mathbf{C}$

Fonte: Fornecido por enfermeira, arquivo pessoal, reproduzido com autorização

As fotos acima foram escolhidas por profissional da equipe e as referentes ao território foram retiradas antes da época da pesquisa de campo. Na ocasião, diversos moradores viviam às margens do córrego da Água Branca, além do conjunto habitacional lá presente. $\mathrm{Na}$ ocasião da pesquisa de campo, a região estava conforme registro nas fotos seguintes.

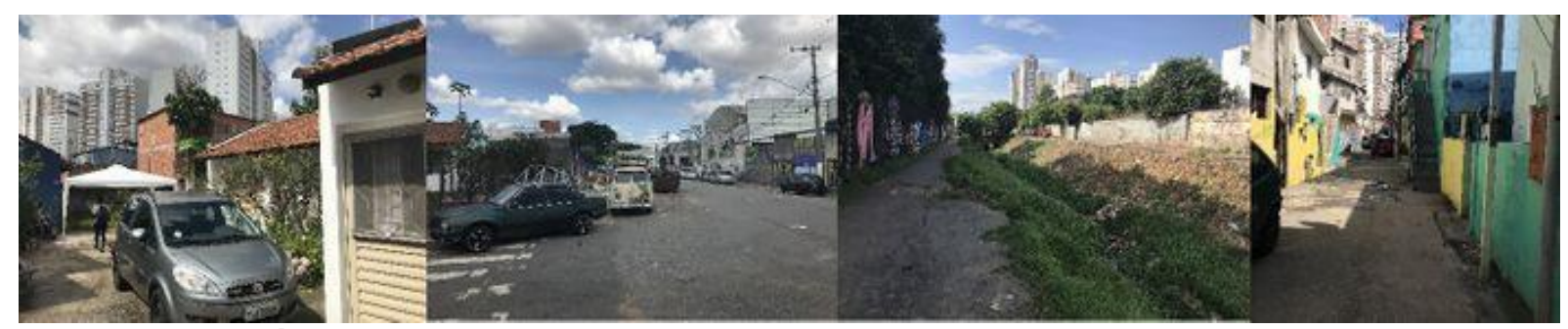

Figura 7 - Território - equipe $\mathbf{C}$

Fonte: Arquivo pessoal da autora - durante realização de trabalho de campo. 


\subsection{OS NARRADORES}

A seguir apresentarei os principais dados demográficos dos entrevistados, tantos os acima de 60 anos quanto os profissionais de saúde. Os nomes utilizados são fictícios, a fim de manter o sigilo dos entrevistados.

\subsubsection{Os narradores "60 mais"}

Foram entrevistados oito idosos, com idade entre 74 e 90 anos, dos quais, 6 com mais de 80 anos $(81,82,84,89$ e 90$)$ e 2 com idade inferior a 80 anos (74 e 75 anos). Em relação à distribuição de sexo por idade, foram entrevistados dois homens ( 81 e 89 ) e seis mulheres $(74,75,82,84$ e 90$)$. Um dos idosos se declarou negro, 2 pardos e os demais brancos. Quanto à escolaridade, dois se declararam analfabetos, um com ensino fundamental incompleto, um com fundamental completo e quatro com ensino superior. Dois dos entrevistados trabalham (74 e 75 anos), sendo que uma diariamente em um shopping como costureira e outra é artesã. Um idoso é pensionista, um recebe Benefício de Prestação Continuada ${ }^{22}$, dois são aposentados por invalidez (um por amputação de membro e outra por cegueira, mas essa também possui aposentadoria por tempo de serviço e continua desempenhando seu ofício de artesã) e os demais aposentados por idade ou tempo de serviço (incluindo a costureira e a artesã). Um dos idosos optou por não informar a renda. Dos demais, a renda variou de $\mathrm{R} \$ 700,00$ a $\mathrm{R} \$ 4.654,20$ (conforme informado no cadastro na Unidade Básica de Saúde). Quanto à composição domiciliar, dois entrevistados moram com os filhos. Uma com o seu filho divorciado que também já é idoso (64 anos) e outra com duas filhas, uma solteira e uma divorciada. Três idosos moram sozinhos, sendo que destes, uma não possui familiares próximos e os outros dois recebem visitas quase diárias de um dos filhos. Os outros três participantes vivem com outro idoso (um com o cônjuge e outras duas com um irmão ou irmã). Dois dos entrevistados não tiveram filhos, os demais tiveram entre 1 e 14 filhos. A idosa

\footnotetext{
${ }^{22}$ O Benefício por prestação continuada é um benefício assistencial de um salário mínimo por mês pago a idosos a partir dos 65 anos ou deficientes de qualquer idade que comprovem baixa renda. Não requer contribuição anterior ao INSS para que se tenha direito.
} 
que foi mãe por 14 vezes possui, vivos, apenas 6 filhos atualmente. Quanto à situação de moradia, 6 dos entrevistados possuem casa própria, uma mora de aluguel e outro em uma moradia cedida pelo programa "Vila Dignidade" da Companhia de Desenvolvimento Habitacional e Urbano do Estado de São Paulo. As residências dos entrevistados possuem entre 4 e 10 cômodos. Sete dos entrevistados se declararam cristãos, sendo dois protestantes e cinco católicos. Um se declarou ateu. Quanto ao estado marital, três são viúvas, um casado, dois divorciados e duas solteiras. Todos os entrevistados são usuários da unidade de saúde, duas possuem também planos privados de saúde e os utilizam mais para a realização de exames complementares de maior complexidade, pois preferem o atendimento clínico na unidade de saúde. Outros dois possuíam até cerca de 1 ano um convênio, mas por mudanças em sua situação econômica, cancelaram. O que os aproximou mais dos serviços da UBS. Dos idosos entrevistados, cinco recebem o atendimento médico pela equipe da unidade de saúde principalmente por visita domiciliar (por restrição de mobilidade, uma por deficiência visual e um por ser o único cuidador de sua esposa com demência de Alzheimer, que o impede de sair de casa), uma frequenta o Centro Dia e outra possui seguimento com o Programa de Acompanhante de Idosos (PAl). O quadro I, a seguir, sintetiza o perfil dos idosos entrevistados, na sequência as figuras apresentam os genogramas e os ecomapas dos depoentes (mais informações sobre símbolos e as ferramentas no Anexo 5). 
Quadro 1 - Caracterização geral dos entrevistados idosos

\begin{tabular}{|c|c|c|c|c|c|c|c|c|c|}
\hline Nome & Sexo & $\begin{array}{l}\text { Idade } \\
\text { (anos) }\end{array}$ & $\begin{array}{l}\text { Estado } \\
\text { marital }\end{array}$ & $\begin{array}{c}\text { Escolarida } \\
\text { de }\end{array}$ & Religião & $\begin{array}{c}\text { Situação } \\
\text { trabalhista }\end{array}$ & $\begin{array}{c}\text { Núcleo } \\
\text { domiciliar }\end{array}$ & $\begin{array}{c}\text { Situação } \\
\text { de moradia }\end{array}$ & Renda (R\$) \\
\hline lara & $F$ & 84 & Viúva & $\begin{array}{l}\text { Fundamenta } \\
\text { I incompleto }\end{array}$ & Católica & Pensionista & $\begin{array}{l}\text { Filho } \\
\text { (idoso) }\end{array}$ & $\begin{array}{c}\text { Apartamento } \\
\text { próprio }\end{array}$ & $4.654,20$ \\
\hline Sônia & $F$ & 74 & Solteira & $\begin{array}{l}\text { Superior } \\
\text { completo }\end{array}$ & Católica & $\begin{array}{c}\text { Aposentada } \\
\text { (invalidez + } \\
\text { idade), } \\
\text { artesã ativa }\end{array}$ & Irmã (idosa) & Casa própria & $4.654,20$ \\
\hline Carmen & $F$ & 90 & Solteira & $\begin{array}{c}\text { Superior } \\
\text { completo }\end{array}$ & Católica & Aposentada & Sozinha & $\begin{array}{c}\text { Apartamento } \\
\text { próprio }\end{array}$ & $\begin{array}{r}\text { Não } \\
\text { informado }\end{array}$ \\
\hline João & $M$ & 81 & Casado & $\begin{array}{l}\text { Superior } \\
\text { completo }\end{array}$ & Ateu & Aposentado & $\begin{array}{c}\text { Esposa } \\
\text { (idosa) }\end{array}$ & $\begin{array}{c}\text { Apartamento } \\
\text { próprio }\end{array}$ & $2.400,00$ \\
\hline Dirce & $F$ & 82 & Viúva & $\begin{array}{c}\text { Não } \\
\text { alfabetizada }\end{array}$ & Protestante & \begin{tabular}{|c} 
Benefício \\
de \\
Prestação \\
Continuada \\
\end{tabular} & $\begin{array}{l}\text { Irmão } \\
\text { (idoso) }\end{array}$ & Casa própria & 700,00 \\
\hline Ivete & $F$ & 75 & Divorciada & $\begin{array}{l}\text { Fundamenta } \\
\text { I completo }\end{array}$ & Católica & $\begin{array}{c}\text { Aposentada } \\
\text {, costureira } \\
\text { ativa }\end{array}$ & $\begin{array}{l}\text { Filhas } \\
\text { (duas) }\end{array}$ & $\begin{array}{l}\text { Casa } \\
\text { alugada }\end{array}$ & $2.499,00$ \\
\hline Rute & $F$ & 90 & Viúva & $\begin{array}{l}\text { Superior } \\
\text { completo }\end{array}$ & Católica & Aposentada & Sozinha & Casa própria & $3.500,00$ \\
\hline Joaquim & $M$ & 89 & Divorciado & $\begin{array}{c}\text { Não } \\
\text { alfabetizado }\end{array}$ & Protestante & $\begin{array}{c}\text { Aposentado } \\
\text { por } \\
\text { invalidez }\end{array}$ & Sozinho & $\begin{array}{c}\text { Moradia } \\
\text { CDHU }\end{array}$ & $1.600,00$ \\
\hline
\end{tabular}

Fonte: O autor (2020) 
IARA

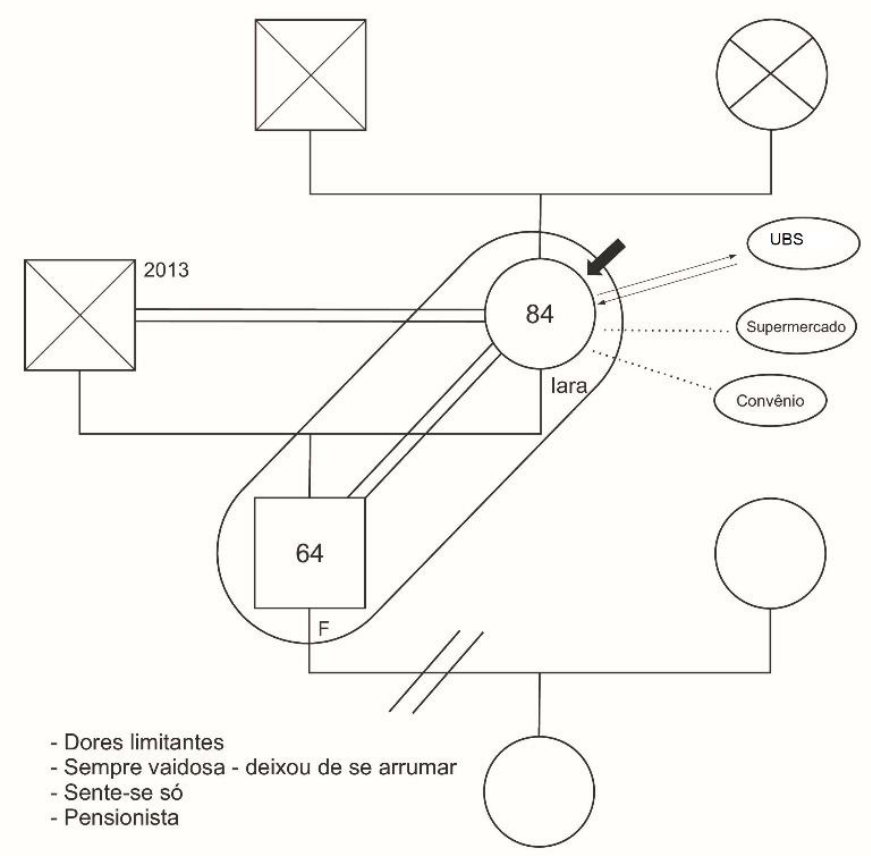

Figura 8 - Genograma lara

Fonte: O autor (2020)

SÔNIA

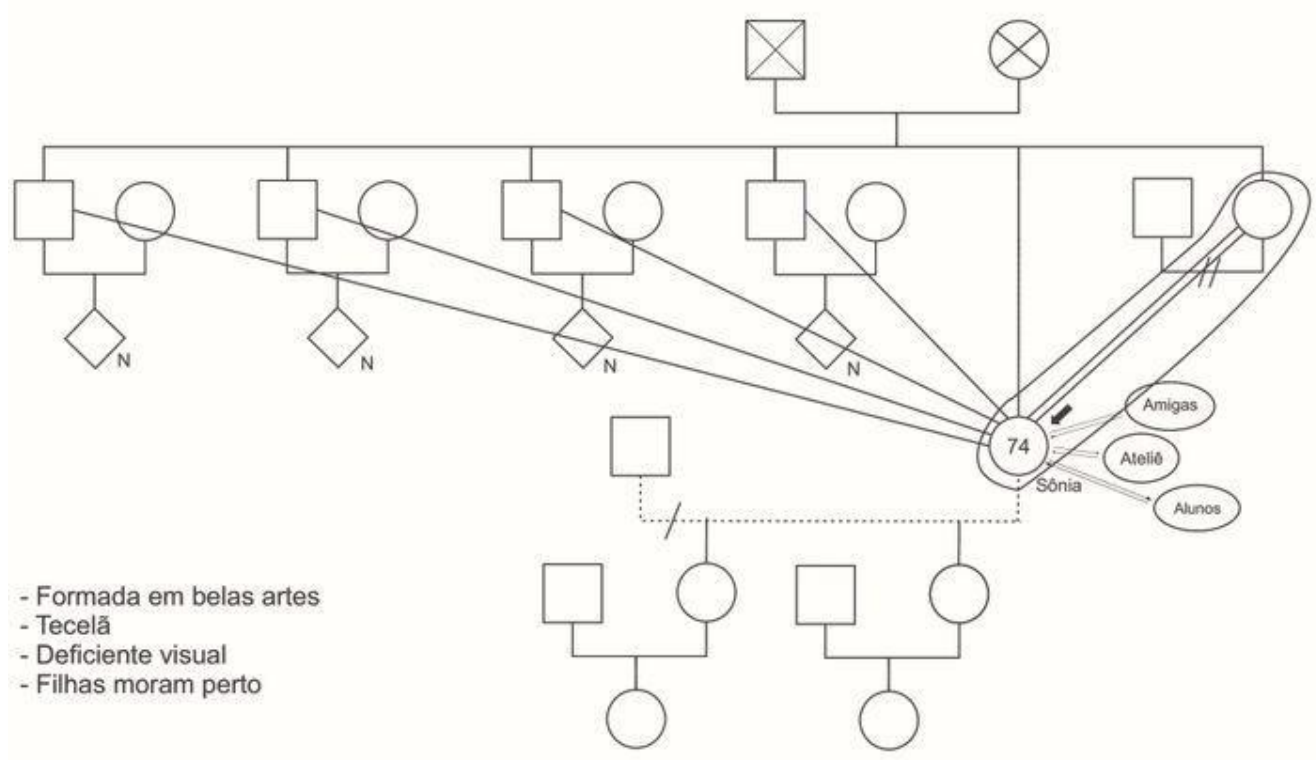

Figura 9 - Genograma Sônia

Fonte: O autor (2020) 
CARMEN

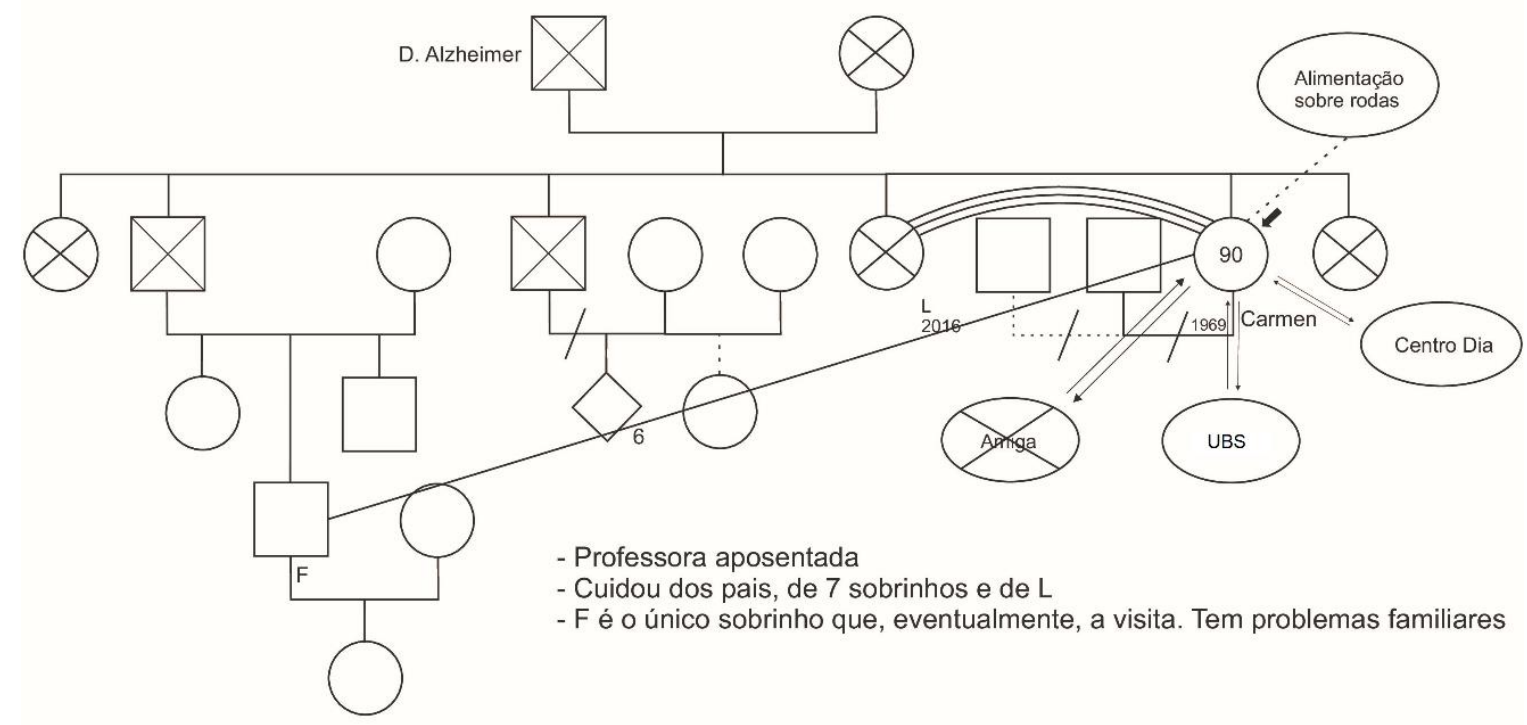

Figura 10 - Genograma Carmen

Fonte: O autor (2020) 
JOÃO

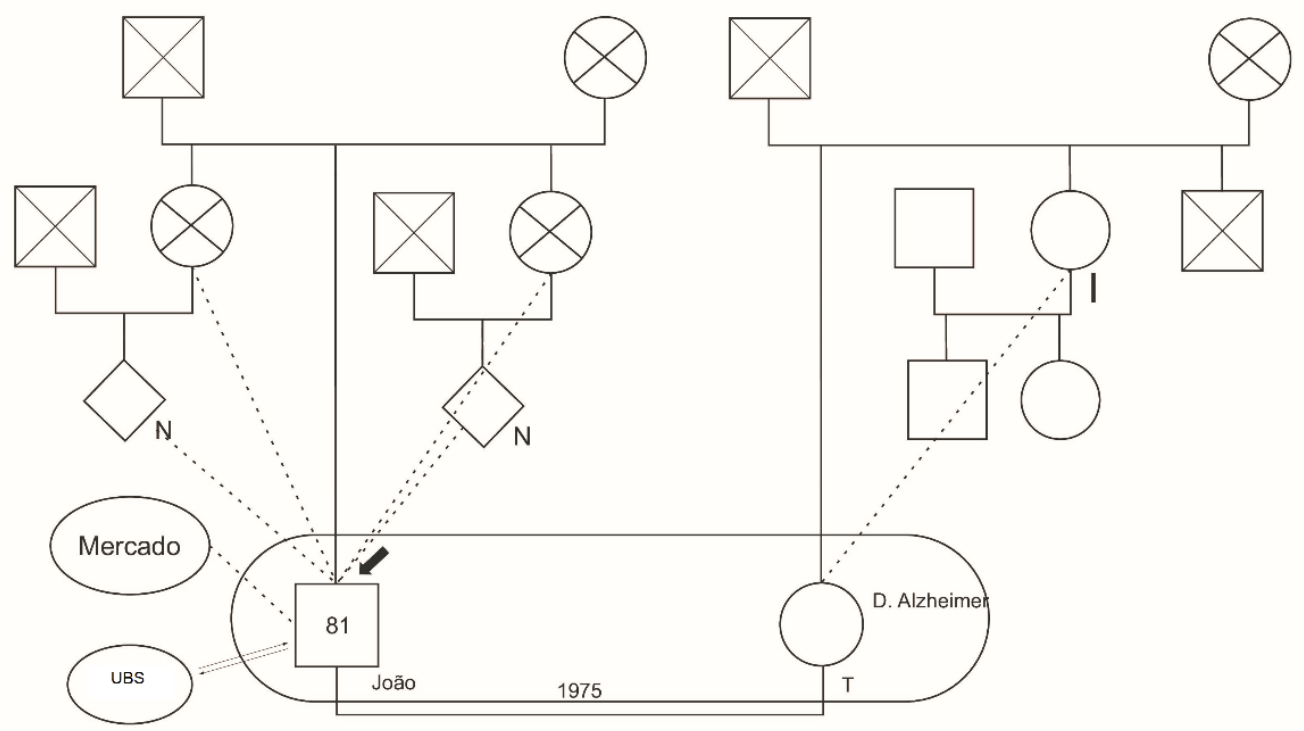

- Desempenhou diversas atividades profissionais ao longo da vida - Lamenta-se por não ter mantido recursos financeiros na velhice

- I mora em Portugal

- T é portuguesa e era cantora de Fado

- João raramente sai de casa porque é o único cuidador da sua esposa

\section{Figura 11 - Genograma João}

Fonte: O autor (2020)

\section{DIRCE}

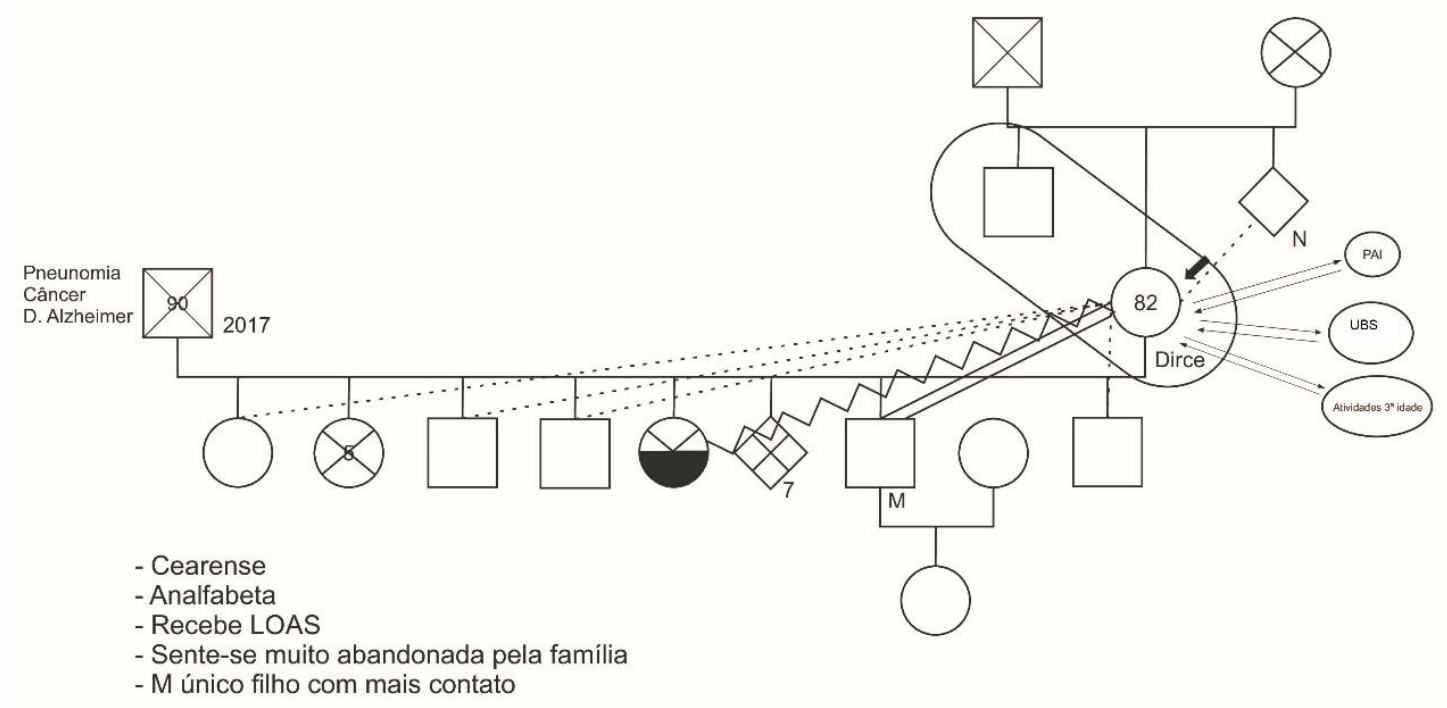

Figura 12 - Genograma Dirce

Fonte: O autor (2020) 
IVETE

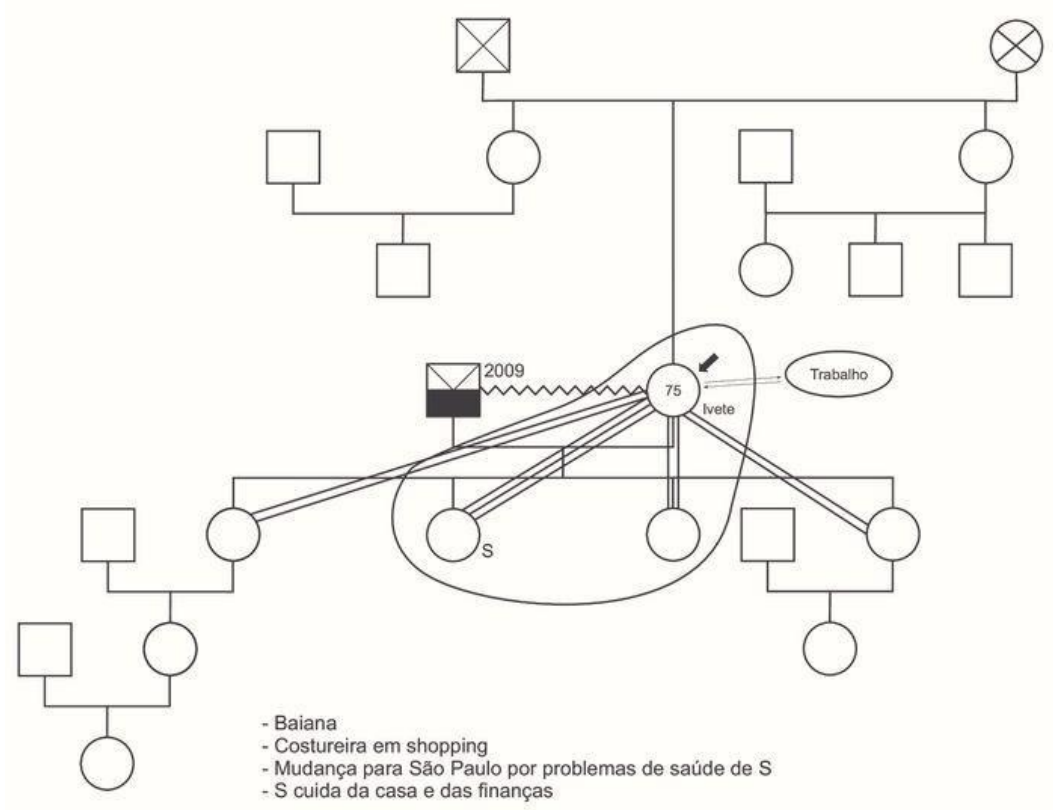

Figura 13 - Genograma Ivete

Fonte: O autor (2020) 


\section{RUTE}

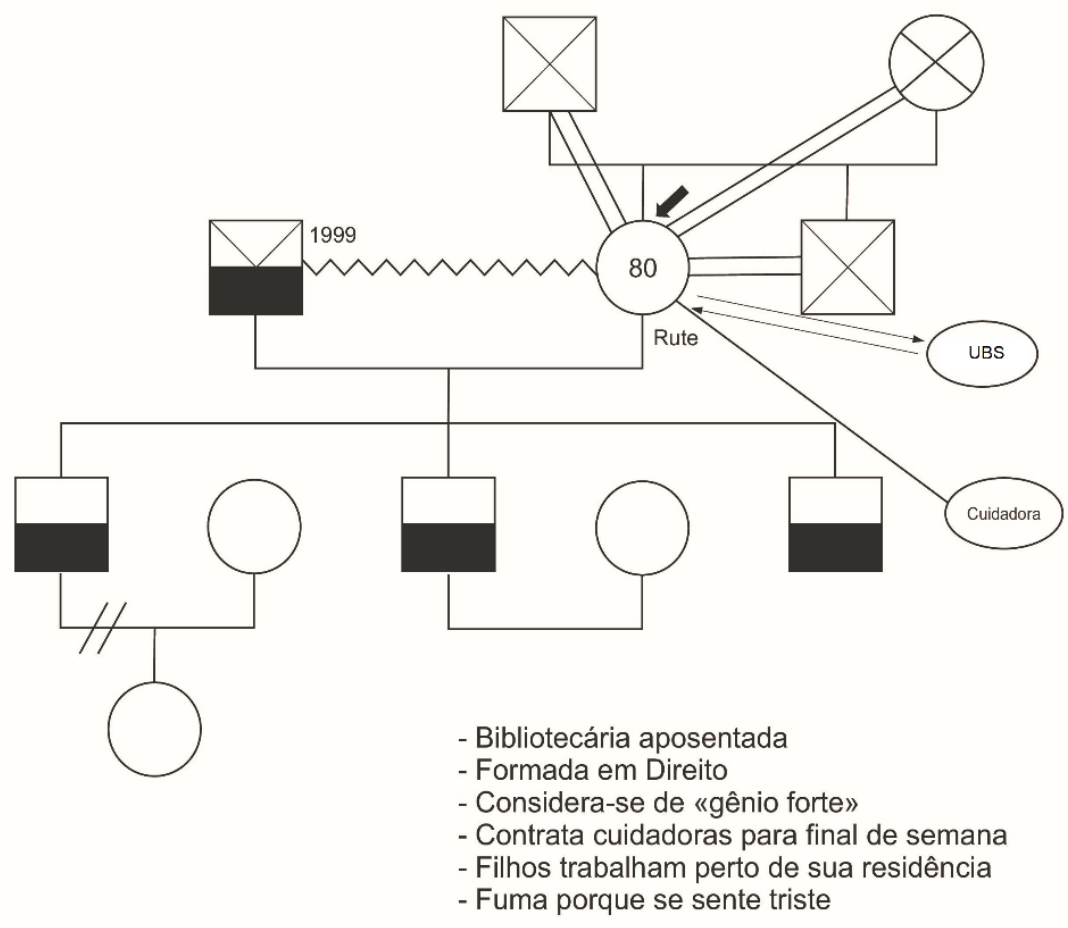

Figura 14 - Genograma Rute

Fonte: O autor (2020) 


\section{JOAQUIM}

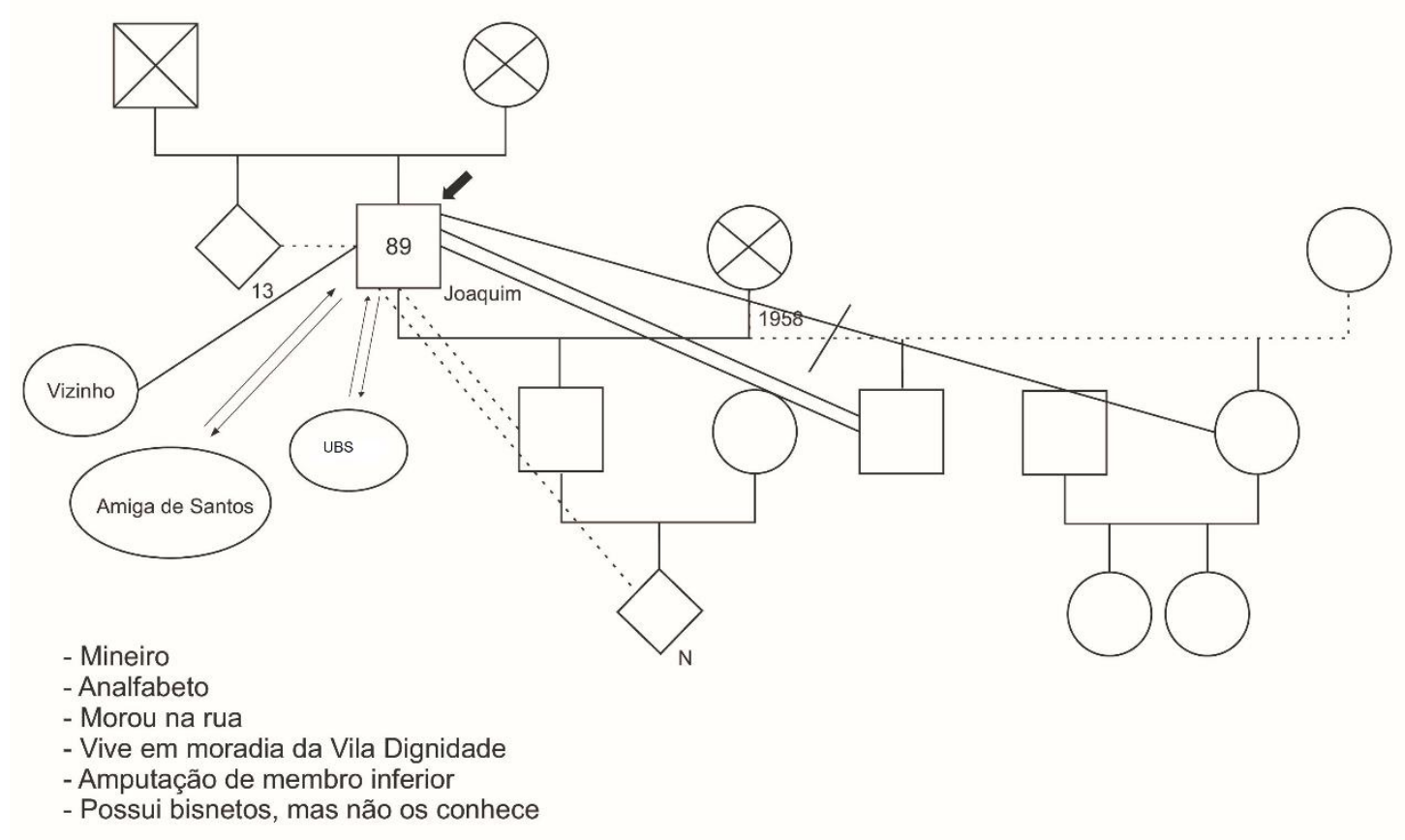

Figura 15 - Genograma Joaquim

Fonte: O autor (2020)

\subsubsection{Os narradores profissionais de saúde}

Foram entrevistados dezesseis profissionais de saúde, com idade entre 29 e 67 anos, tempo de atuação no serviço variando de 1 mês a 17 anos e sendo 3 do sexo masculino e os demais do feminino. Três migrantes (Itália, Bolívia e Chile) e os restantes brasileiros. Uma se declarou negra, 4 pardos e os demais brancos. Destes 16 profissionais, 14 compunham as equipes de Saúde da Família, sendo 7 Agentes Comunitários de Saúde, 2 técnicos de enfermagem, 3 enfermeiros e 2 médicos de família e comunidade (MFC). Além destes, foram entrevistados uma geriatra e uma assistente social. Estas não compunham uma equipe de NASF-AB, mas sim faziam parte do serviço por terem sido entendidos como uma demanda do local. A assistente social trabalha no serviço há cerca de 10 anos. A Geriatra trabalhou anteriormente no CS como 
Clínica Geral por cerca de 1 ano e há menos de um ano retornou como geriatra. Ambas participavam das reuniões de equipe semanalmente em atividade de matriciamento e ofereciam atendimento à população adscrita ao serviço. $O$ quadro a seguir apresenta a lista dos entrevistados e sua função.

Quadro 2 - Relação dos entrevistados profissionais de saúde e sua função

\begin{tabular}{|l|l|}
\hline \multicolumn{1}{|c|}{ Nome } & \\
\hline Carla & Agente Comunitária de Saúde \\
\hline Laura & Agente Comunitária de Saúde \\
\hline Soraia & Agente Comunitária de Saúde \\
\hline Martha & Agente Comunitária de Saúde \\
\hline Rafael & Agente Comunitário de Saúde \\
\hline Olívia & Agente Comunitária de Saúde \\
\hline Berenice & Agente Comunitária de Saúde \\
\hline Dulce & Técnica de enfermagem \\
\hline Diego & Técnico de enfermagem \\
\hline Martina & Enfermeira da Estratégia Saúde da Família \\
\hline Fabiana & Enfermeira da Estratégia Saúde da Família \\
\hline Carolina & Enfermeira da Estratégia Saúde da Família \\
\hline Andrea & Médica de Família e Comunidade \\
\hline Fernando & Médico de Família e Comunidade \\
\hline Débora & Assistente social \\
\hline Daniela & Geriatra \\
\hline
\end{tabular}

Fonte: O autor (2020)

\subsection{O ENVELHECIMENTO}

A percepção sobre o envelhecimento é um ponto importante para se atingir o sucesso prático no cuidado que se propõe a compartilhar com o idoso. Entender a noção de si do idoso como tal e a própria percepção dos profissionais é importante para que se consiga traçar estratégias de cuidado que sejam compatíveis com as expectativas, necessidades e projetos de felicidade do usuário. 


\title{
5.2.1 A noção de si
}

Mesmo sendo um fenômeno mundial, o envelhecimento populacional é um processo heterogêneo, marcado por condições sociais, culturais, biológicas e pela trajetória de vida (Camarano; Kanso; Mello, 2004; Brasil, 2018). A partir de todos esses fatores, têm-se as diversas definições do que é o envelhecimento, conforme abordado na primeira parte deste trabalho. Segundo alguns autores, a considerar esse contexto, é a auto definição do sujeito que orienta a determinação de qual etapa da vida em que se encontra (Debert, 1988).

Se por um lado há um olhar próprio da sociedade sobre o envelhecimento e o velho, para o próprio indivíduo que envelhece há uma dificuldade em construir a identidade de idoso. Não é incomum o sentimento "muito generalizado, de se ter uma espécie de máscara imposta ao corpo que esconderia a identidade mais profunda da pessoa, a qual continuaria sendo essencialmente da mesma juventude" (Motta, 2002, p. 42). Sobre a dificuldade em se constituir a identidade no idoso, Debert, afirma:

\begin{abstract}
A velhice não é uma identidade permanente e constante. Para indivíduos de idade avançada, o velho é sempre o "outro". Suas práticas cotidianas e a reflexão que fazem a respeito de sua experiência pessoal são marcadas por uma série de mecanismos de resistência ao processo de envelhecimento. Esses mecanismos ganham formas bastante particulares quando se trata de homens ou mulheres, mas é preciso levá-los em conta nas propostas de práticas visando a um envelhecimento adequado (Debert, 1988, p. 538).
\end{abstract}

A noção de si como idoso, para os entrevistados, foi semelhante ao observado por Debert (1988) em que a percepção de que o "idoso é sempre o outro" foi algo marcante. Em geral, o fato de não se sentir idoso vinha acompanhado de uma justificativa, como um mecanismo de resistência.

Não. Me sinto jovem ainda. Idoso por quê? A única coisa que eu tenho aborrecimento é que eu não posso andar mais (...). Aqui em casa sou eu que limpo minha casa, lavo minha roupa, faço minha comida, eu que faço tudo. (Joaquim, 89 anos).

Se eu me sinto idoso? Ainda não. Por enquanto, ainda não. (...) Eu faço almoço, eu faço o jantar, eu faço café. Eu ajudo a limpar a casa.(João, 81 anos). 
Entrevistadora: A senhora se sente idosa?

Ivete: Não, se eu te falar a verdade não. Quando eu estou trabalhando eu não tenho dificuldade, porque a gente trabalha levantando e agachando marcando barra, e agacha, marca barra, eu não tenho dificuldade para isso, para agachar, para levantar (Ivete, 75 anos)

Não sinto que eu sou idosa. Tão idosa, não sinto, né? Porque tá faltando sabe o que é? Coragem e saúde. (...) Eu acho que a pessoa que é velho, ele é a pessoa, assim, que não pode fazer suas coisas mais, que não pode andar sozinha mesmo, que ainda tem seus $90 \mathrm{e}$ poucos anos. Ô, 90 não, porque o meu Zé morreu com 91 anos e parecia que não tinha essa idade. $E$ tem gente aí que tá com 90 e poucos anos e trabalha até, eles trabalha ainda (Dirce, 82 anos).

Em geral, o sentimento de envelhecer e o enfrentamento da velhice apresentam diferentes dimensões também entre os sexos (Nogueira; Alcântara, 2014).

Debert (1988), conforme resultado de estudo qualitativo em que entrevistou idosos acima de 70 anos, explicita que, quando considerado o contexto social atual, para as mulheres idosas a experiência do envelhecimento vem carregada de maior liberdade, positivamente avaliada, em especial com o marcado discurso da oposição entre o "antigamente" e o hoje. Para os homens, por outro lado, a liberdade positiva dentro da experiência do envelhecimento é a econômica. Nos casos em cuja vida não houve uma ascensão econômica, o bem estar é referido a partir da realização de muitas atividades, mesmo quando já não se desfruta do mesmo vigor da juventude. Para os homens, quer considerem positiva a experiência do envelhecimento, quer não, impera a análise de que a vivência do velho no passado era privilegiada em relação aos dias atuais em função da posição de respeito que os idosos desfrutavam nas comunidades. Segundo esse mesmo estudo de Debert as mulheres apresentam aceitação quanto ao fato de que a aparência sofre as mudanças pelo processo biológico, mas mantêm a resistência ao processo ao não se entregarem (o "espírito pode resistir"). Nesta condição, a continuidade em executar o trabalho doméstico passa a ser um dos mecanismos de resistência. Para os homens, em contrapartida, nos estudos de Debert, e em outros, acentuava-se a manutenção da lucidez como forma de resistência, envolvendo o reconhecimento de que não 
se é mais jovem. Estes entendem a experiência de que envelheceram especialmente a partir da parada das atividades profissionais. Neste trabalho, contudo, em ambos os gêneros, o mecanismo de resistência foi a possibilidade de realizar as tarefas domésticas, podendo-se falar em um processo de feminização do homem velho.

Interessante observar ainda que a percepção de envelhecimento (ou de não envelhecimento) não é constante e nem mesmo homogênea dentro do próprio indivíduo, porque, não raro, a pessoa não se sente idosa em todas as situações e há sempre partes ou funções que se mantêm mais jovens que outras (Debert, 1988; Motta, 2002).

Saúde que eu não tenho mais, a gente tem que se costumar com tudo, porque a gente vai ficando de idade, vai ficando doente, dói os ossos, dói uma coisa, dói outra, o que a gente faz muita extravagância quando é novo, quando é velho vai juntando tudo aquilo, aí quando chega naquele bloco, é aquele aiaiai uiuiui, tem noite que dorme, tem noite que não dorme, é desse jeito, o corpo dói muito, ficar só deitado não dá. De uns tempos para cá emagreci muito (Joaquim, 89 anos).

Eu gosto de fazer coisas que jovem faz, ouvir música, ouvir programa legal, assistir um filme, essas coisas [fala filha: WhatsApp, Facebook] também, eu gosto de ficar assim, eu não me sinto... eu me sinto idosa pelo documento, mas pelo meu físico, minha cabeça, eu não me sinto idosa. (Ivete, 75 anos)

Carmen: Eu fiz dia 7 de agosto, 90 anos.

Entrevistadora: Parabéns.

Carmen: Eu não falo para ninguém porque senão pensa que eu tô lelé da cuca e eu não estou, minha cabeça é de 30 , por isso que o corpo briga com a cabeça e a cabeça briga com o corpo, a cabeça quer uma coisa e o corpo não obedece, e tô vivendo assim né (Carmen, 90 anos).

Entrevistadora: $E$ a senhora se sente idosa?

Rute: Eu não.

Entrevistadora: Para a senhora, o que é ser idoso?

Rute: Uma pessoa implicante, não quer isso, não quer aquilo, não quer aquele outro, não aceita as pessoas que queiram ajudar, o que mais... que não tem mais condições de andar sozinho, o que mais... Não tem mais condições dessa... Não tem mais condições de andar sozinha, o que mais... bom, nesse ponto sou idosa, sou rabugenta, isso eu sou (Rute, 90 anos). 
Sônia, 74 anos, ao ser interrogada se sentia idosa, afirmou que se sente apenas em alguns momentos. Quando ela se sente idosa se deve a alguns sintomas que apresenta "na canseira. A canseira é a pior coisa que eu tenho... Outra coisa que acontece é a cabeça, o raciocínio é bom, mas o esquecimento desfavorece".

A partir das narrativas dos entrevistados, tanto idosos quanto profissionais de saúde, como veremos a seguir, quando presente, o sentimento de envelhecimento é vinculado, mais do que à idade cronológica, à perda de funcionalidade ou presença de doenças. Nos relatos de lara e Carmen, por exemplo, as únicas que se definiram como idosas, é a partir da dor (doença) ou de mudanças fenotípicas que notaram o próprio envelhecimento.

Se eu me sinto idosa? Vou falar uma coisa para você, até uns três meses atrás, mais ou menos, talvez um pouco mais, um pouco menos, eu comecei a me sentir. Porque eu sempre fui uma pessoa que sempre me tratei muito bem, sempre me vesti muito bem, você está pedindo, sempre me vesti muito bem, frequentei bons lugares com o meu marido, até passava o pessoal e me admirava. Minhas sobrinhas, do lado do meu marido, eu sou a querida delas porque elas cresceram tudo pensando no que eu fazia: os brincos grandes, vestido sem costas, tudo essas coisas, sabe? Sapatos bem altos... mas de um mês e pouco eu estou com uma dor na perna, na coluna, e eu me senti que nesse mês eu envelheci. Não sei se é o cabelo também que eu não penteio, não tenho coragem nem de ir à cabeleireira e nem de fazer... [a unha, mostra o gesto] (lara, 84 anos)

Entrevistadora: E a senhora se sente idosa?

Carmen: Sinto, sinto por causa das dores, da cabeça não.

Entrevistadora: A senhora se lembra de alguma situação especial que fez com que começasse a se sentir idosa?

Carmen: Depois que a Lucinha morreu eu cai na real, antes não (...) Eu era mais alta, encolhi, fiquei pequena. Então, porque que eu vou achar a velhice bonita? Entende? Não tem como. Eu fico olhando aquelas senhoras que frequentam lá o centro, aquelas cabecinhas brancas, cabelos... eu já falei que cai tudo na velhice, começa a cair os dentes, cai o nariz, cai o peito, cai a bunda, cai em casa, cai na rua, onde que tá a beleza? Entendeu? Não gosto da velhice e se eu não tivesse essa dor eu ia lutar ainda contra a velhice, eu não ia andar se eu não tivesse essa dor, eu ia voar.(Carmen, 90 anos)

Esta percepção é alinhada com a visão de pobreza do envelhecimento, mais do que com a noção de que se trata de mais uma etapa da vida. Apesar 
dos diversos esforços nas políticas e na mídia em se trazer a velhice para a perspectiva do envelhecimento ativo ou saudável, mesmo com a mudança de signos para terceira idade e melhor idade, por exemplo, a velhice ainda é encarada como oposto da juventude ou vem marcada com a presença da doença ou da perda de vitalidade. Esta mesma dificuldade em distinguir o normal do patológico, a velhice da doença, é o que é apresentado por Groisman (2002) como um dos dilemas da gerontologia.

Por fim, ainda quanto à percepção do que é envelhecimento, lara e João trouxeram a definição a partir, também, do isolamento social. Esta solidão apareceu de forma importante nas diversas narrativas dos velhos, na percepção de envelhecimento por parte de alguns profissionais de saúde, como veremos a seguir e também como um dos desafios da realização do cuidado, de forma que a solidão será abordada em outra categoria mais adiante.

Eu fazia tudo sozinha, já que eu tinha minha mãe, meu pai, é isso que eu acho que é envelhecer. Os amigos se afastam, isso é duro também. A gente fala "poxa, tinha tanta gente", você muda de local parece que você foi embora para o exterior, não interior, exterior. Você não recebe um telefonema, você não recebe uma visita, uma carta, nada, só de você falar "vou mudar para tal bairro", "ah, me dá seu telefone, me dá seu endereço", acaba (lara, 84 anos).

Eu me sinto tão bem, agora a única coisa que eu fumo, porque eu fico aqui sozinha (Rute,90 anos)

Entrevistadora: E já teve alguma coisa que aconteceu que o senhor falou assim: "Nossa, acho que tô envelhecendo."?

João: É a gente só nota a distância das pessoas. Quando você, a idade vai chegando, as pessoas vão se distanciando. Eu não sei se é o problema financeiro, que as pessoas têm medo de que a gente vai pedir alguma coisa. Principalmente famílias e amigos mais chegados (João, 81 anos)

Tavares et al. (2017) em revisão integrativa, analisou a percepção dos idosos sobre o envelhecimento saudável em diversas dimensões. $\mathrm{Na}$ psicológica, identificou que para os idosos o entendimento de um envelhecimento saudável se dá pela manutenção do otimismo e da felicidade. $\mathrm{Na}$ espiritual, da fé e espiritualidade. $\mathrm{Na}$ social, os idosos destacaram a relevância das relações sociais (família, amigos e companheiro), sendo 
apontada a importância de ser ajudado e de ajudar. Quanto à biológica, o entendimento dos idosos se dá quanto a relevância da adoção de hábitos de vida saudáveis (e.g. prática de atividades físicas, alimentação saudável, não tabagismo e/ou etilismo).

Quanto ao envelhecimento bem-sucedido, ter saúde e bons relacionamentos também foram preponderantes nas narrativas dos idosos deste estudo. No discurso dos idosos do sexo masculino, a manutenção de recursos financeiros também foi um ponto apresentado, em especial por conferir dignidade e respeito, diferença essa de gênero também observada no estudo de Debert (1988).

[Envelhecer bem é] Estar bem com a sua família porque você sabe que vai ser bem atendida, bem querida, embora eles vão falar por trás, "a mãe está ruim", eu sei muita coisa da vida (lara, 84 anos).

Envelhecer bem para mim, é estar bem comigo mesma, estar bem com a família, ter um objetivo todos os dias, para ocupar o dia, gostar das pessoas, não sentir mágoa (Ivete, 75 anos)

Entrevistadora: E, pra senhora, o que significa que a pessoa envelheceu bem, assim?

Dirce: Eu nem sei te responder. Por causa que eu sou uma mulher tão sofrida na vida, que eu não sei responder.

(...)

A pessoa envelhecer com saúde é bom demais. E você faz o que você pode fazer, o que você pensa em fazer, né? E faz. (Dirce, 82 anos)

Envelhecer bem é envelhecer com dinheiro, com uma situação econômica boa. E ter amigos, ter pessoas pra conversar, ter... Saúde... No contexto da família, quando fala amigos pra sair, tá a família. Ter dinheiro pra comprar o que quer, o que pode, né?

(...)

É quando você pode, você tem autoridade, chega num lugar, as pessoas te respeitam, porque você tem dinheiro. Então isso que é uma vida bem sucedida. Então você tem que ter caráter, acima de tudo. Depois, o dinheiro pra poder comprar e ganhar o respeito das pessoas (João, 81 anos)

Um movimento interessante que ocorre na velhice é o retorno ao mercado de trabalho por apresentarem algumas vantagens para o contratador: como 0 não exigir a carteira assinada, o passe livre em transportes, a fila especial e por 
outras virtudes como paciência e experiência, deixando, em contrapartida, os idosos se sentirem mais saudáveis e ativos (Motta, 2002). Ivete e Sônia, que ainda trabalham, apresentaram também suas atividades laborais como importante fonte de utilidade e prazer, conferindo valor especial a essa dimensão.

Entrevistadora: Para você, o que é envelhecer bem?

Sônia: Envelhecer bem? A primeira coisa de ser... a boa coisa que me deixa bem é ser artesã, eu ter o que fazer .

Entrevistadora: E para você o que significa ter uma vida bem sucedida?

Sônia: É um prazer interno meu, meu sucesso não é para os outros, é para mim mesmo.

Entrevistadora: Para você, o que mostra que você teve sucesso?

Sônia: Porque eu gosto do que eu faço.

(Sonia, 74 anos)

Outro fator relacionado ao bem-estar na velhice é a geratividade. Ela se expressa na preocupação em garantir condições para que a geração seguinte possa viver bem e destaca que o idoso pode fazer algo em favor de si tendo em vista o bem que pode realizar para outros. Ela transparece tanto em deixar bens materiais quanto em prestar cuidado para outros. O quanto ela é vivenciada depende de expectativas sociais, suporte social e escolaridade. Para as mulheres, em geral, envolve o autocuidado para poder cuidar das gerações mais novas. Para os homens, o autocuidado é estimulado para a continuação da passagem de valores. Esse construto valoriza, então, o bem-estar a partir da perspectiva relacional e oferece oportunidades para explorar a gestão do cuidado tanto individual quanto coletivo (Lima, 2003). Carmen, ao poder compartilhar seus conhecimentos com os outros usuários do Centro Dia também traz a percepção de bem estar ao se sentir útil.

Carmen: (...)e as velhinhas também são muito boas, elas gostam muito de mim, porque eu ensino elas, faço tricô, faço pintura, faço... ensino elas a falarem certo que elas pedem para corrigir quando elas erram, que mais, faço argila, faço um monte de coisas de atividades várias.

Entrevistadora: E o que isso significa para a senhora?

Carmen: Utilidade. Eu me sinto útil (Carmen, 90 anos) 
Se o processo de manter-se ativo remete à noção de bem estar e utilidade, o estímulo para continuação da execução dessas tarefas, quer sejam domésticas, quer sejam laborais ou em centros de convivência, desponta como uma possibilidade potente para o sucesso prático do cuidado com o idoso.

\subsubsection{A percepção de envelhecimento pelos profissionais de saúde}

Para os profissionais de saúde houve diferentes entendimentos do que caracteriza a velhice. História pessoal, experiência familiar, características da formação profissional e contato com a comunidade foram fatores que influenciaram nas diferentes percepções sobre o envelhecimento.

A idade cronológica ou o critério etário - que mensura a passagem do tempo decorrido desde o nascimento - ainda que seja um dos meios mais simples e usuais de se obter informações de uma pessoa e de ser adotado por vários entrevistados, é um conceito multidimensional e indicada por diversos profissionais como sendo inadequada para identificação do que é ser idoso, sendo normalmente utilizada em conjunto com outros critérios. O mais citado, de forma geral, foi o vinculado às perdas, mudanças da capacidade funcional ou mesmo alterações do fenótipo. Assim, em geral, o envelhecimento para muitos profissionais está relacionado à idade biológica, que é definida pelas "modificações corporais e mentais que ocorrem ao longo do processo de desenvolvimento" (Schneider; Irigay, 2008, p. 590), compatível com o foco do ensino nos cursos da saúde e com o predomínio do entendimento do envelhecimento ainda da perspectiva da miséria ou das doenças: o estereótipo do abandono, da solidão, da pobreza e da doença; voltado para medidas assistenciais(Lima, 2003).

Tem a faixa etária, né? [risada] Que, infelizmente, a partir dos 60 anos, considera idoso. Mas, na verdade, na funcionalidade, na possibilidade de autonomia, de trabalho. Autonomia em todos os sentidos, tanto autonomia física, autonomia das atividades de vida diária, autonomia econômica. Tem muitos idosos que, no caso, seriam maiores de 60 anos, que não seriam idosos. Porque são pessoas totalmente ativas, que trabalham, que são independentes, que fazem atividade esportiva, que mantém uma vida social e de relação muito ativa. Então, acho que, assim, o que eu consideraria idoso é... [risada] Não sei. (Andrea, MFC). 
Berenice: Eu vejo pela idade. Então eu acho que é pela idade, mas tem idade que não parece que é idosa.

Entrevistadora: $\mathrm{E}$ quando não é a idade, o que você olha que parece que está ficando idoso?

Berenice: Pelas doenças, né, como pressão alta, diabetes, o jeito que a pessoa tem de qualidade de vida, a casa, a gente vê tudo, a higiene da pessoa, como ela é, como ela sai, como tem cuidado, eu vejo isso, vejo tudo. (Berenice, ACS)

Idoso, assim, porque com 60 não parecem ser idosos. Tem pessoas que são mais ativas que eu ainda. Eu tenho uma paciente com 92 anos, ela está lúcida, ela faz hidroginástica, agora está deixando de ir um pouco, mas idoso, assim, na minha área, que eu considere idoso que não consegue fazer nada, eu não tenho. (Olívia, ACS)

Soraia: Não só a idade. Eu uso o critério de todo mundo. A gente vê que a pessoa que fica idoso, ela fica mais lenta, entendeu? Lenta no andar, lenta no falar, lenta no exercício.(...) Pra mim, o idoso a partir dos 60 anos é considerado idoso. Por quê? Porque ele só vai perdendo um monte de coisa nesse mundo que a gente vive.

Entrevistadora: O que?

Soraia: Um monte de possibilidade. Possibilidade de trabalho, possibilidade de mostrar o quanto ele é necessário. (Soraia, ACS)

Bom, além da aparência, claro, das mudanças físicas, principalmente pela queixa do esquecimento que eles vêm trazendo. Até não são... São jovens idosos, idosos jovens, de 50 e poucos, 59, 60, 61, que se queixam que tão esquecendo muitas coisas. Coisas que sabiam que era da rotina, de repente "Deixei panela no fogo. Deixei chuveiro ligado." (...) Ah, a parte do fenótipo mesmo, sabe? Cabelo começa a ficar mais branquinho, grisalho, ruguinhas. A coluna, às vezes, começa a entortar um pouco. (Carolina, enfermeira)

O principal, que é nítido, é o declínio físico, é a sarcopenia, a falta de músculo, isso que te dá o fenótipo claro do envelhecimento, que passa de uma pessoa hígida, ereta, para uma pessoa que altera o centro de gravidade para frente, que tem um passo menos espaçado, que eleva menos a perna e às vezes quando precisa de outra pessoa, ou indivíduo para se locomover. Isso não tem muita idade, isso acontece com 60 anos para uns, com 80 para outros, ou até para uns excepcionais acontece com 100 anos isso. Mas é nítido esse fenótipo mesmo da fraqueza muscular que você enxerga, independente das comorbidades, de como estão os controles das suas outras doenças. Isso é bem marcado para os idosos e para a gente de que você saiu de uma fase adulta e começou a passar por uma fase de envelhecimento mais claro. (Daniela, geriatra)

Entrevistadora: O que aconteceu com a Dona E. que você achou que ela envelheceu?

Carla: Acho que foi o sofrimento mesmo, era só ela e o esposo dela, de repente o esposo faleceu no apartamento 
Entrevistadora: $E$ o que você viu nela que parece que ela envelheceu?

Ela emagreceu, está um pouco mais abatida, mais rugas, não tinha tanto, está com bastante rugas, o cabelo está bem mais ralo, eu achei ela bem diferente em um mês. (Carla, ACS)

Existe a nota de corte, que é a faixa de idade, mas a gente sabe que tem idoso de 70 anos que está ótimo, está praticando atividade física, se alimenta bem. Acho que a parte da velhice aí é mais relacionada ao estilo de vida, à alimentação, como a pessoa está fisicamente, a cabeça, acho que é uma avaliação global que a gente tem que fazer mesmo. Às vezes a cabeça está boa e fisicamente a pessoa está ruim, e o contrário também é verdadeiro, a pessoa está bem, mas a cabeça não está boa. Então a partir não só se ele vem com uma queixa de que está sem energia, dificuldade para fazer as coisas, limitação de movimento, de marcha, ou às vezes alguma alteração de memória, aí a gente vai olhando a partir daí. Mas a gente sabe que tem a idade a partir de tal idade a pessoa é considerada idosa.(Fernando, MFC)

Primeiro a gente faz o recorte pela faixa etária. Mas a gente sabe que, hoje, 60 anos é praticamente um adulto, né? A gente vê que os idosos da $3^{\text {a }}$ idade, da $4^{\text {a }}$ idade aí tão crescendo muito. Então a gente vê idosos, mesmo com 60 anos, muito funcionais, né? (...)

Quando eu comecei, há dez anos, tinha uma funcionalidade maior, eram idosos jovens e que, ao longo desses anos, foram adquirindo doenças e perdendo muito a funcionalidade, perdendo muito a autonomia. (...) Então eu vejo que teve essa piora mesmo. (Fabiana, enfermeira)

Eu venho atendendo essa pessoa durante anos e noto o declínio desse paciente. Porque ele me traz que estava com maior problema de saúde, paciente diabético insulino-dependente está com dificuldade na aplicação nos horários da sua medicação, da aspiração da insulina, no geral os pacientes começam a ter mais dificuldades na tomada das medicações, a situação mental, se mora sozinho, se tem família. (Martina, enfermeira)

Ainda associado à percepção de declínio, alguns profissionais relataram o aumento das queixas no discurso das pessoas como indicativo de envelhecimento. $O$ que se mantém na perspectiva do envelhecimento relacionado a perdas, mas considerando o ponto de vista do próprio usuário

É difícil saber, mas o start é esse que eu tô pegando. Muitos pacientes meus tão reclamando. Reclamando, não. Se queixando. "Ó, tô cansado. Tô começando a ficar um pouco esquecido." Então, eu já comecei a perceber que tão dando sinais. Aí eu vou comparar idade e 
tudo mais, e atividades e eu vejo que já tão entrando na faixa dos idosos já. (Rafael, ACS)

Entrevistadora: Quais sinais que, às vezes, te ajudam pra visualmente notar o envelhecimento?

Dulce: Então, o que eu percebo é essa coisa de... Desse tipo de fala mesmo. Começa a ficar um pouco mais "reclamão", sabe? Assim, reclama mais. Começa a... A fisionomia mesmo, assim, fica mais abatida. Cê percebe a pessoa mais cansada, a pessoa desanimada, fala que não tem vontade de nada. (Dulce, técnica de enfermagem).

De fato, nem sempre a delimitação etária foi um fator tão importante nas sociedades ocidentais. Na pré-modernidade o status da família era mais importante do que a idade para a determinação da maturidade e do controle dos recursos de poder. Já na modernidade ocorreu a cronologização da vida. Neste período a individualização foi operada por meio da institucionalização do curso de vida. Os estágios foram divididos claramente e a fronteira foi a idade cronológica. A "cronologização da vida", por sua vez, serviu não apenas para caracterizar como a vida foi se transformando, mas também para dar um caráter de instituição social para o curso de vida presente em quase todas as dimensões do mundo familiar e profissional (Debert, 1999). Na pós-modernidade se deu uma desconstrução do curso de vida, com vistas a uma descronologização. Novos arranjos familiares, diferentes idades de casamento, do nascimento dos filhos e da diferença de idades entre os pais, impacto das mídias (permitindo acesso às crianças a aspectos da vida característicos da idade adulta, trazendo preocupações, linguagem e formas de lazer mais generalizadas do que voltadas a uma faixa etária específica) tendem a ofuscar os limites. Contudo, ao invés de uma postura mais tolerante em relação às idades, observa-se que esse embaçamento se inclina a transformar a ideia de que o bom velho é aquele que se mantém jovem, dada a valorização atual de tudo que é jovem. Atualmente também é vivenciada uma mudança cultural na forma de pensar e gerir as etapas da vida, especialmente o envelhecimento. As linhas mais tradicionais da gerontologia adotavam o envelhecimento na perspectiva da miséria. Atualmente, a perspectiva do idoso como fonte de recursos sociais ou da velhice bem sucedida tem sido muito apresentada e valorizada. Ela traz uma redefinição positiva da experiência do envelhecimento e a ressignifica como um momento oportuno para expressão de novas formas de atividade e participação social 
(Lima, 2003). Porém, alguns autores, como Debert (1999), ressaltam que, de certo modo, a perspectiva da velhice bem sucedida tenta encobrir a da miséria. A partir de um conjunto de "recomendações e receitas, passa a propalar um novo ideal de produtividade, que busca ensinar, aos que não querem se sentir velhos, a maneira adequada de conduzir a vida e participar de atividades preventivas" (Lima, 2003, p. 8).

A experiência de envelhecimento no âmbito familiar também é um dos recortes utilizados pelos profissionais em sua percepção do envelhecer. Além disso, a experiência profissional também pode direcionar o foco do entendimento da velhice para um dos seus fatores. Num dos relatos abaixo, o técnico de enfermagem, que trabalhou inicialmente em hospital e participa muito dos grupos de diabéticos de sua equipe, traz definições como "agudo" e "crônico", em geral relacionadas à fases de uma patologia, para o processo de envelhecimento. A assistente social, como profissional que matricia as equipes e lida em especial com as situações de vulnerabilidade social, apresenta a percepção de envelhecimento que dialoga com a esfera dos direitos, da moral e da ética.

Minha mãe também completou 60 eu percebi que começou a fazer uns esbranquiçados. É, não tem muito como identificar a fase aguda do idoso, eu não consigo distinguir de fato se ele é um idoso, que tem o idoso novo, que é o idoso de 60 anos que está ativo, está trabalhando, muitos deles ainda estão trabalhando, que tem a sua parte de locomoção íntegra, fala, se movimenta, faz um monte de coisa. Agora a parte do idoso que já está mais entrando para o crônico acho que se baseia em exames, acho que já está mais com a pressão arterial alterada. Ah, não sei, enfim. (Diego, técnico de enfermagem).

Pela idade, principalmente, né? Sessenta anos, assim, pelo Ministério [da Saúde], tal, né? Mas 60 eu acho muito jovem ainda. (...) Eu tiro pelo meu pai. Meu pai vai fazer 67 esse ano. Super ativo, muito mais que eu. Super bem. Toma um remédio pra pressão alta. Tá controlada sabe? Super ativo. e 67, no tempo que o pai dele era idoso, já era muito velho, né? (Carolina, enfermeira)

Como diria, é a construção que a gente tem do idoso no Brasil. Dizer que aqui no Brasil a gente está avançando nos direitos dos idosos, sim, mas dizer que a gente está mudando a forma cultural como a gente vê o idoso, ah, é outra história. A lei está indo por um caminho, mas a moral e a ética, desculpa, não está junto. É tão comum ver na fala das pessoas "mas ele está velho, está inválido, não presta para mais nada", então se ele não presta ele deixa até de ser um ser de autonomia, 
porque como ele dá trabalho, ele é algo, é um peso, essa palavra sempre aparece, um peso, então se ele é um peso que tenho que colocar ele no meu esquema, para me facilitar, porque ele deixa de ser algo, alguém. É tão forte isso que já vi famílias quererem tirar a identidade da pessoa, até o gosto; teve casos que a gente vai que a pessoa não tem nem o direito de escolher o que ela gosta de comer, já é dado a ela o que ela vai comer, não estou dizendo do idoso vulnerável, que precisa de alimentação domiciliar, não é isso, mas é aquela coisa de escolher (Débora, assistente social).

Uma das profissionais ainda fez menção ao processo de envelhecimento como uma ligação com o passado e poucas perspectivas para o futuro, dentro da visão fenomenológica. Ela afirma que o que difere um mais jovem de um idoso seja "talvez a possibilidade de fazer planos pro futuro. A mudança se vê quando a pessoa tá mais focada no passado, no máximo no presente, do que no futuro." (Andréa, MFC).

Por fim, de forma compatível ao relatado por alguns idosos, o envelhecimento também foi relacionado ao isolamento social para os profissionais, ora decorrente do abandono por terceiros, ora por uma mudança de comportamento da própria pessoa que envelheceu.

Eu percebo quando ela não sai mais, não tem mais aquela vontade de sair, de curtir a vida, eu vejo isso, fica mais isolada, está lá no seu cantinho (Laura, ACS)

Nem sempre o velho ou o idoso, você pensa na idade. Mas você pensa nas mudanças de vida dele, né? Começa a ter os esquecimentos, as restrições pra tudo, né? E começa a ficar um pouco mais isolado. Isso não é $100 \%$. Mas a gente começa a perceber que esses idosos começa, assim, a ficar um pouco mais isolados, não querem muito sair de casa e isso faz com que essa pessoa, realmente, ela tá mostrando mais que aquela idade está fazendo com que... Os problemas de saúde tá vindo, então a gente considera que essa pessoa, nesse momento, tá ficando mais idosa, né? (...) Assim, vários pacientes vinham aqui, com maior disposição e participavam de muitas atividades que a gente tinha e, de repente, foram decaindo, sabe? Comecei a perceber até a vinda aqui começou a se tornar um pouco maior. Mais em função de ajuda. Não de "Ai, eu quero participar dessa atividade, eu quero participar de um Lian Gong" ou "De viagens, de café..." Que a gente sempre faz com os pacientes. E eu comecei a perceber que esses pacientes começaram a vir mais "Ah, não. Não quero participar. Tô desanimado. Não..." Só vem mais pra consulta ou pra pedir uma ajuda mesmo. Ou aqueles mesmo que você percebe, assim, visualmente o envelhecimento. (Dulce, técnica de enfermagem) 
Não sei se, às vezes, é a solidão (Martha, ACS - ao ser interrogada sobre quando nota que alguém está envelhecendo).

Entrevistadora: Qual que é o critério que você usa pra dizer que um paciente é idoso ou não é idoso?

Soraia: Eu acho, assim, eu percebo na minha área, na minha área tem muito idoso abandonado, entendeu? Abandonado, porque eles mesmos querem ficar abandonado. Idoso que eu falo, assim, a partir de 60 anos, tá? Eu vejo que a necessidade de uma pessoa a partir dos 60 anos é ter mais apoio. Apoio, assim, reunião entre amigos, entendeu? Um esporte, uma atividade. E eu não vejo idoso, eu vejo essa pessoa a partir dos 60 anos, muitos sendo abandonados e sendo esquecidos (Soraia, ACS).

Os profissionais de saúde consideram, de forma geral, como envelhecimento bem-sucedido, não apenas a ausência de doença, mas a possibilidade de autocuidado e manutenção de independência.

Que envelhecer bem é um estado mental, antes de tudo, mais do que físico. Isso até pensando nos vários, na percepção de saúde de vários pacientes idosos. Que eu tenho pacientes com muitas comorbidades, com hipertensão e que ainda se considera que está bem. Então, acho que tá envelhecendo bem essa pessoa. Então é mais um estado de bem-estar mental, físico, claramente. Porque uma pessoa que vive com dor, por exemplo, não se sente bem. E que não prejudica possibilidade de fazer planos e de conseguir ter atividades que dão prazer e manter essas atividades que dão prazer, que mantém interesse, que mantem ativa a possibilidade mental e relacional. (Andrea, MFC)

É estar na senescência, né? Não na senilidade. Então, ser um idoso com saúde, mesmo que tenha doenças. Que se mantenha funcional. Que se mantenha com relações sociais. Que mantenha uma vida quase normal, assim. Que consiga fazer suas atividades do dia. Consiga, se quiser, trabalhar. Que tenha dinheiro pra comprar suas coisas, né? Que consiga se alimentar bem. Que seja uma pessoa feliz. (Fabiana, enfermeira)

Tavares et al. (2017) em estudo que apresentou as definições de um bom envelhecimento do ponto de vista dos idosos, afirmou que na esfera biológica foram consideradas as possibilidades de se alimentar bem e praticar exercícios físicos. Esses fatores também foram apresentados como alguns profissionais de saúde como marcadores de um bom envelhecimento. 
Eu acho que ter uma família estruturada, alimentação também ajuda, coisas mais naturais, viver de algumas coisas naturais, exercício também acho que a pessoa vai ter um envelhecimento mais saudável. (Laura, ACS)

Estar com saúde, fazer atividades que você gosta, fazer caminhadas, ter atividades diferentes para eles. Mientras tendo [enquanto tiver] isso é um idoso bem ativo. (Olívia, ACS)

Acho que alimentação. Você receber uma boa alimentação. Atividade física, acho que é uma coisa. Ler. Ler, acho que é uma coisa que é importante pro envelhecimento, pra você evitar ele, adiá-lo, né? Eu gosto muito de ler, então falo por mim. Atividade física nem tanto, né? Nem tanto. Acho que é isso. O envelhecer bem é isso. É você cuidar da saúde física do seu mental, né? Fazer suas atividades, respeitando as suas limitações também. Que não adianta a gente querer fazer muita coisa, passar dos limites, também. Mas acho que é isso. Acho que envelhecer bem, eu acho que é isso. É você saber os seus limites e se dispor a fazer atividade, alimentação. (Rafael, ACS)

A prática desses hábitos de vida tidos como saudáveis para a população geral é um dos fatores importantes para prevenção e controle das doenças crônicas não transmissíveis (DCNT - principais responsáveis pela morbimortalidade nos idosos) e é consoante à política nacional de saúde da pessoa idosa, sendo previsto que sejam trabalhadas pela APS em diversas oportunidades: visitas domiciliares, atividades de educação em saúde e consultas médicas e de enfermagem, dentre outros. Os esforços profissionais em relação às DCNT são fortemente voltados ao estilo de vida individual, consoante ao movimento descrito por Debert (1999) como reprivatização da velhice, de forma que a responsabilidade sobre a aquisição do hábito de vida saudável recai quase exclusivamente sobre o idoso. Sobre este ponto, a literatura apresenta duas discussões distintas. De um lado se pressupõe o estímulo a esta postura de auto-responsabilização do idoso e, de outro, postulase que seja estimulada com cautela, haja vista o peso dos determinantes sociais de saúde (Tavares et al., 2017). Possivelmente pelo enforque nessas práticas, o controle das comorbidades foi apresentado por alguns profissionais como indicativo de um bom envelhecimento, mas essa percepção não foi referida pelos idosos. 
É um paciente que ele vem, por mais que ele tenha alguma doença, ele vem na consulta e ele demonstra ser uma pessoa feliz, de bem com a vida, com um auto-cuidado bom. Tem aqueles pacientes que enganam a gente, que são felizes, tem toda uma dificuldade, mas a gente descobre por que a gente faz visita domiciliar. Mas o paciente envelhecer com uma boa saúde é aquele que eu sei que tem muitas dificuldades, mas consegue se auto-cuidar e têm esses problemas bem resolvidos, tanto os físicos, emocionais, familiares, ele vem e está estável, tem uma pressão boa, tem uma glicemia boa, os exames dele estão bons, a gente vê isso através dos exames, talvez. (Martina, enfermeira)

Para alguns profissionais, em especial dentre os que participam mais da vida em comunidade dos velhos, o critério da presença de recursos financeiros foi apresentado como um dos determinantes de um bom envelhecimento. Em alguns momentos das entrevistas é enfatizada a diferença de acesso ou qualidade de envelhecimento entre os idosos com maior e menor renda.

Entrevistadora: Para você, o que é envelhecer bem?

Carla: Acho que, pensando em mim eu penso em todas as áreas, financeiramente bem, emocionalmente bem, familiar... que pergunta difícil! Acho que com saúde, tenho poucos pacientes que têm vida de classe média então eu vejo que eles têm condições melhores, eles podem envelhecer bem, passeando, eles têm condições de fazer uma viagem, eles podem comprar os medicamentos, não dependem só do SUS, podem optar em fazer academia, então eu acho que é uma boa maneira de envelhecer, os filhos são próximos, a família é bem estruturada. (Carla, ACS)

A percepção de bom envelhecimento também se dá através da vivência de cada profissional, não só na esfera laboral, mas também na pessoal. Alguns, a referem como uma projeção de como pretendem estar na sua velhice.

Entrevistadora: E para você, o que é um envelhecimento bom, um envelhecimento bem-sucedido?

Diego: Ah, eu acho que um envelhecimento que deveria ser natural para todo mundo é um envelhecimento que você não viva à base de remédio, que você uma alimentação saudável, tenhas seus exercícios físicos, não tenha debilidade nenhuma para andar, para se movimentar, ter uma qualidade de vida saudável, normal saudável, que não dependa de muitas coisas. (...) Uma velhice boa seria uma velhice que você possa viajar, que você possa sair de onde você está, que você possa ter uma vivência de outros lugares, não ficar só em casa esperando que morte te leve, passear, curtir os netos, espero que eu 
possa ter netos também, possa me divertir, possa me alegrar, mais ou menos isso. (Diego, técnico de enfermagem)

Entrevistadora: E para você o que é envelhecer bem?

Berenice: Ter dinheiro, poder gastar, viver bem, alimentação, higiene, passear, para mim, é isso, se eu pudesse ter tudo isso (Berenice, ACS)

A ACS citada no excerto acima possui dificuldades financeiras importantes e cuida de dois idosos em sua casa, com limitação para mobilidade. Tanto que refere que não tem prazer em retornar para casa, que se sente presa em casa.

A percepção de envelhecimento bem-sucedido apresentado pela geriatra abarcou sentidos trazidos pelos idosos, como a importância da família, dos bons relacionamentos, da estabilidade financeira e a manutenção da independência e da autonomia.

Entrevistadora: E o que é para você um envelhecimento bemsucedido?

Daniela: É um envelhecimento que a gente chama de senescência. Senilidade seria um envelhecimento patológico e senescência seria um envelhecimento natural, normal, que você vai diminuindo suas reservas corporais, mas isso não significa dependência e debilidade. Para mim envelhecer bem sucedida é você envelhecer e continuar funcional, continuar autônoma, independente, no seu meio, ou seja, não precisar de outra pessoa para realizar todas as suas atividades. Porque o declínio físico, o declínio cognitivo vai acontecer em maior ou menor grau, mas o que você mais vê assim a pessoa orgulhosa aos 80,90 anos é que elas são independentes, que elas fazem tudo sozinhas e que elas continuam cuidando de $\mathrm{si}$, isso é, claramente, o principal marco para mim do envelhecer bem. Até os próprios idosos me transmitiram essa noção do que é envelhecer bem. É envelhecer com amigos, perto da família, ter recurso financeiro e ter autonomia para ir e vir e fazer o que bem entender da vida. (Daniela, geriatra)

A compreensão do sentido do ser idoso deve ser colocada em perspectiva histórica e temporal. Cultura, tempo histórico, classe social, trajetória de vida pessoal, educação, estilo de vida, gênero, profissão, etnia e diversas outras dimensões da vida variam para formular as heterogêneas experiências de velhice e envelhecimento (Assis, 2004; Burlá, 2014). O entendimento de como se dá o processo de envelhecimento e as formas de resistência a esse processo são particulares a cada indivíduo e devem ser considerados nas propostas 
assistenciais quando se visa uma co-construção de práticas de saúde que sejam conciliadoras com a vida. Assim, entender a percepção do usuário e a do próprio profissional de saúde são pontos importantes na relação de cuidado.

\subsection{AUTONOMIA E PRÁTICAS DE CUIDADO}

\subsubsection{De qual autonomia se fala?}

Mesmo considerando-se que a autonomia é essencial para a prática do Cuidado, bem como valor reforçado pela legislação, políticas nacionais e internacionais; a definição da autonomia, como discutido anteriormente, não apresenta um consenso, particularmente no campo da saúde. Contudo, estamos de acordo com o que afirmam Paranhos e Albuquerque (2018):

\footnotetext{
Para que os dilemas surgidos nas relações de cuidados sejam eticamente enfrentados, é necessário compreender, primeiramente, no que consiste a autonomia do paciente idoso, suas peculiaridades e abrangência, levando-se em conta que cada sujeito, em sua singularidade, faz escolhas baseadas em uma realidade social particular (Paranhos; Albuquerque, 2018, p. 35).
}

Assim, o primeiro passo ao se tratar das relações de cuidado e autonomia precisa partir do entendimento do que é a autonomia para os profissionais de saúde e para os idosos, expressa diretamente ou nas relações.

Dentre os profissionais de saúde, a autonomia ora era valorizada no campo da funcionalidade, como a independência para realização de atividades básicas ou instrumentais de vida diária, ora como capacidade de decisão.

Ir ao mercado, pagar as contas, tomar banho sozinho. Tem uns que não conseguem nem fazer isso, né? Infelizmente. Preparar comida sozinho, ir ao cinema. Fazer tudo que quer, independente das pessoas. Sozinho ou acompanhado, mas sem depender de alguém para. (Carolina, enfermeira).

Funcionalidade a gente conceitua como a aptidão do indivíduo para realizar atividades do seu cotidiano, sejam elas atividades instrumentais, para morar sozinho, para viver com independência, sem depender dos outros, como atividades básicas que são aquelas para 
sobreviver. Você ser funcional, ser ativo significa você ser independente de outras pessoas, o quanto você depende ou não de outro indivíduo para fazer suas atividades, é uma questão muito mais física para mim. Diferente de autonomia, que é uma questão muito mais de capacidade de decisão, mesmo que você dependa fisicamente de outro indivíduo, você tem sua autonomia, sua capacidade plena de decisão do que você quer que seja feito para sua vida ou não, acho que um fala mais da parte física e o outro fala mais da parte cognitiva. (Daniela, geriatra).

Eu acho que autonomia é o direito dele escolher, é o direito de escolha dele. Eu sempre tive uma crítica muito grande de que a saúde sempre foi egocêntrica, a saúde sempre foi assim "eu sei o que é melhor para você", não sabe. Eu tenho visto cada vez mais que a gente às vezes até interfere na intimidade do outro de uma maneira que não é legal, tem formas da gente interferir sendo um pouco menos direto (Débora, assistente social).

Para a profissional seguinte, a autonomia do idoso também é pertinente ao campo de capacidade de decisão, mas tem o limite tensionado até o ponto em que se identifica que a escolha do idoso possa ser prejudicial à sua própria saúde ou integridade.

E aí tinha a questão de você estar tirando a autonomia do paciente, mas é uma autonomia que eu dou para ele, eu dou várias chances para ele ter autonomia, mas chega uma hora que você não pode ficar sentada, então a autonomia dele... eu preciso até ultrapassar essa questão da autonomia às vezes, ultrapassar não de uma forma do paciente falar assim "não, não quero tratar, que se dane", a gente respeita, a gente para o serviço, anota no prontuário, não tem o que fazer, mas eu sei que a gente sempre precisa tentar um pouquinho mais ( Martina, enfermeira)

Dentro dos processos que seguem em judicialização, conforme o entendimento legal da autonomia, a capacidade de decisão (ou o julgamento) também é um dos principais critérios ponderados ao se definir o seguimento de um caso. Uma vez colocado em diálogo com o entendimento da maior parte dos profissionais da relação da autonomia com a funcionalidade (ou posta em relação direta entre maior autonomia e maior independência para realização das atividades de vida diária), traz-se à tona uma das situações que geram angústia na atenção ao idoso e que versa sobre esse desencontro de percepções: quando o idoso manifesta o seu desejo de que não quer algo e os profissionais de saúde entendem que o melhor para ele (ao se considerar a independência ou capacidade funcional) é outro caminho. 
Esses casos, quando o idoso não quer absolutamente nada, são os casos que mais causam ansiedade e estresse na gente, na equipe. Porque a gente vira espectador de um espetáculo que não é muito legal. Quando a gente tenta discutir os casos com o Ministério Público ele diz o seguinte: em que medida você considera ele incapaz? Nenhuma. Então tudo que ele decidir ele vai decidir. (Débora, assistente social).

A interface entre funcionalidade e capacidade de decisão se apresenta também em outros recursos acessados para a atenção ao idoso. Ao afirmar "Mas ela nunca aderiu a nenhuma atividade fora de casa. Porque o intuito do PAl também é esse, é melhorar a autonomia do idoso. Autonomia não se desenvolveu", Fabiana (enfermeira) retrata a expectativa do "desenvolvimento" da autonomia no campo da funcionalidade.

Essa possibilidade de realizar tarefas sem a dependência de auxílio de outros também é expressa por alguns idosos como autonomia e como um valor para a velhice, sendo que o fato de precisar de ajuda para algumas atividades é tido, para alguns, como uma das principais limitações que possuem no cotidiano.

Já tenho problema de sair, de andar sozinha, meu filho precisa largar de trabalhar para me levar. Eu fico sentida só, assim, de não poder fazer, de precisar pedir para uma pessoa que trabalha o dia inteiro e depois chega em casa e precisa fazer outras coisas que eu poderia fazer. Mas se eu posso fazer eu faço (lara, 84 anos).

Entrevistadora: A senhora consegue fazer as coisas que gostaria de fazer?

Carmen: Nem tudo.

Entrevistadora: O que, por exemplo?

Carmen: Por exemplo, limpar a minha casa quando não tem empregada, tirar pó eu não posso abaixar por causa da coluna, tenho muita dor, cuidar da casa melhor, eu só ponho as coisas em ordem, pendurar as roupas que eu deixo a semana inteira que eu vou tirando, cada dia eu ponho uma roupa, eu deixo em cima da cama, chega no sábado tem que pendurar tudo, é um sacrifício porque o varal é alto. Eu gostaria de fazer muita coisa que eu não posso, fazer comida para mim variada, mesmo porque eu tenho que comprar alguns ingredientes, porque eu tinha um almoço sobre rodas e eles cortaram, porque eles souberam que eu almoço lá no ... No centro [Centro dia], mas acontece que eu guardava o almoço na geladeira para comer de noite. (Carmen, 90 anos) 
Um pouco deprimida, sim, porque eu sempre fui uma moça, uma mulher corajosa, fazia tudo, se tem que subir morro subia, fazer isso fazia, hoje já não posso fazer nada, nem subir, não posso mais cozinhar, não tenho força.(Rute, 90 anos).

Péssimo, péssimo porque eu fiquei dependente, totalmente dependente. Não posso sair na rua, não dá para atravessar a rua, o trabalho estanca, por exemplo, eu tenho muita dificuldade, eu enfrento a dificuldade, mas eu tenho muita dificuldade. Se cai uma coisa no chão eu não enxergo, aí eu chamo a Maria, aí a Maria não escuta. Mas vai, vai, vai, eu sou feliz... e agradeço por tudo que Deus me deu (Sônia, 74 anos, ao se referir às dependências decorrentes da sua baixa acuidade visual).

Quando presente a limitação física, o sentimento de inutilidade é expresso em algumas narrativas. Já a capacidade de continuar realizando alguma tarefa (como as domésticas) é tida como um mecanismo de resistência ao envelhecimento (ainda adotado por muitos na perspectiva da miséria).

Dirce: Eu me sinto mal. Me sinto mal, porque eles querem que eu seja a velha acabada e não posso sair de casa mais só. Às vezes, e meto o pé no caminho, vou lá pra Lapa comprar alguma coisa que eu quero e ninguém nem sabe. Quando pensa, eu chego. [ambas dão risada]

Entrevistadora: Mas me conta melhor: esse se sentir mal é mal como? Porque tem vários...

Dirce: Desgosto. Eu fico com desgosto com isso aqui de eu ficar... Eu sinto uma inútil, né? (Dirce, 82 anos)

Aqui em casa sou eu que limpo minha casa, lavo minha roupa, faço minha comida, eu que faço tudo. A menina trabalha junto com o menino na lojinha e às vezes fala "pai, deixa que eu faço", "eu não vou tirar você do seu serviço para depois ele ficar reclamando que está pagando empregado para trabalhar para mim", que o P. reclama, ele não deixa barato as coisas não, é mão de vaca mesmo. Mas, "então vocês ficam quietos lá que aqui eu mesmo faço". (Joaquim, 89 anos).

Por outro lado, se a dependência física gera alguma possibilidade de troca, ela é aceita com maior facilidade. É o exemplo de Joaquim que comprou um carro para que o filho o leve para os lugares (também a outros moradores da Vila Dignidade) e, ao mesmo tempo, permite que o filho use para trabalho como motorista de aplicativo. Já Sônia ao sentir que ser ajudada causa alegria em 


\section{quem ajuda, não se sente mal com a necessidade de apoio nessas circunstâncias.}

Entrevistadora: $\mathrm{O}$ senhor se sente como de ter que depender dele para te levar?

Joaquim: Eu me sinto até bem, porque o carro é meu, não é dele. É dele porque está no nome dele, mas eu que comprei para servir a quem precisa, eu falei "tem paciente que precisa de ir no médico pega e leva, não vai cobrar nada", ele trabalha com a Uber. (Joaquim, 89 anos).

Entrevistadora: O que você sente quando tem que pedir ajuda?

Sônia: Se eu vou pedir para um varredor de rua, a impressão que me dá que eles estão agradecendo de eu pedir de tão delicado, eles largam tudo, largam a vassoura e me pegam pela mão, é fantástico isso, é uma delícia. (Sônia, 74 anos).

A cessão do direito de decisão em caso de se sentir cuidado também é uma troca que é possível e não foi vista com desgosto pelos entrevistados.

Entrevistadora: E é a sua nora que cuida do seu dinheiro?

Rute: Minha nora e meu filho.

Entrevistadora: E como que a senhora se sente em relação a isso?

Rute: Muito bem. (Rute, 90 anos)

Olívia: Aí um dia eu falei "vamos tirar pelos menos esse aqui, vamos deixar esse, esse aqui não", aí assim fomos convencendo elas aos poucos, fomos tirando. Fomos explicando que ela mora sozinha.

Entrevistadora: Ela ficou brava quando vocês foram convencendo devagarinho?

Olívia: Não, não ficou brava, ela falou "vocês se preocupam comigo". (Olívia, ACS)

De segunda a sexta, eu almoço lá a comida é muito boa, eles me atendem muito bem, só que eu já me queixei que eles tiram um pouco a autonomia da gente, não deixa ir ao banheiro sozinha, não deixa ir em lugar nenhum sozinha, tem sempre uma atrás da gente, agora eu já reclamei lá, porque eu reclamo mesmo, não pode sozinha no banheiro, mas voltar pode, porque elas me deixam sozinha no banheiro e saem para ir atender outra pessoa e eu volto sozinha, então, porque que eu posso voltar e não posso ir sozinha? isso eu discuto lá sabe, mas como eles são muito bons eu deixo passar.(Carmen, 90 anos) 
No contexto das relações a manifestação da autonomia aparece, então, de forma complexa. Não delimitada apenas entre funcionalidade e capacidade de decisão, porque na interface das decisões e pactuações, fatores inerentes à história pessoal, cultura, meio social, tecnologia e acesso a programas e políticas interferem na capacidade de autodeterminação e na manutenção da independência.

\subsubsection{A Autonomia do idoso no cotidiano da Atenção Primária à Saúde}

Por sua relação com diversos horizontes da vida, em reuniões de equipe, atendimentos grupos e acolhimento, as questões pertinentes à autonomia e sua preservação no idoso surgem em diversas "situações problemas" que adquirem cores diferentes em cada contexto e subjetividade. Nesse sentido, um entendimento da autonomia sob o prisma biomédico apresentado por Beauchamp e Childress, que parte inicialmente de uma autonomia com a ideia de autogoverno, em que se considera a existência de um indivíduo livre de controle, interferência ou qualquer limitação que o impedisse de realizar uma escolha esclarecida, não parece suficiente para abarcar respostas ao que se apresenta no cuidado do idoso diariamente.

Na visão principialista, o sujeito autônomo seria alguém que, além da capacidade cognitiva plena, estaria imune a qualquer fator externo. Ao mencionarem que pessoas não autônomas são apenas aquelas que estão sob o poder coercitivo de outros, Beauchamp e Childress vislumbraram apenas a dominação física ou moral explícita de um ser por outro. Os teóricos não levaram em conta uma infinidade de elementos externos capazes de influenciar as decisões de pacientes que, ainda que esclarecidos e informados, encontram-se em situação de fragilidade. Com efeito, o exercício da autonomia pelo paciente idoso deve ser entendido sob um espectro mais amplo, examinado no contexto de seus relacionamentos e a partir do reconhecimento de que os seres humanos constroem suas deliberações no seio de suas relações intersubjetivas. (Paranhos; Albuquerque, 2018, p. 38)

A perspectiva de uma autonomia relacional é um dos princípios norteadores dos direitos humanos dos pacientes (ramo do Direito Internacional). $\mathrm{Na}$ ideia da autonomia relacional, ainda que se entenda o indivíduo como principal ator na tomada de decisões e responsabilidades sobre o seu cuidado, 
considera-se que o mesmo esteja entrelaçado numa rede (como ambiente social, cultural, econômico, político, sexo, raça entre outros) que possui interações com seus anseios pessoais (pressupondo a construção pessoal da identidade). A inter-relação dos diversos meios nos quais o sujeito transita, suas tradições e consciência individual levam a uma ponderação de que o exercício de uma autonomia, como no ideal principialista, é de difícil realização (Paranhos; Albuquerque, 2018).

De fato, no contexto da atenção primária, as dificuldades encontradas no cuidado do idoso perpassam a autonomia plasmada com as vulnerabilidades às quais cada idoso está exposto em determinado momento. Dessarte, uma vinculação imediata de limites (próprios da idade para responder a exigências contextualmente postas aos idosos) as restrições impostas ou auto-assumidas à autonomia do idoso é fruto de uma visão unilateral e individualizante, como a criticada por Paranhos e Albuquerque (2018). Olhar para as necessidades de cuidado do idoso por uma ótica relacional e processual de seus limites é um caminho potencial para que se faça da autonomia não uma resistência que precise ser superada para proteger dos riscos trazidos pelo envelhecimento, mas um marcador do quê e do como precisa ser transformado (individual, social e programaticamente) para se Cuidar efetivamente, isto é, para mobilizar recursos técnicos que potencializem sucessos práticos no que se refere à saúde. Nesse sentido, Paranhos e Albuquerque afirmam que

\footnotetext{
Além do respeito ao direito do paciente de fazer escolhas informadas, o profissional da saúde deve atentar ainda para a construção pessoal da identidade por cada paciente. Se a autonomia é desenvolvida e realizada dentro de um contexto social, é necessário estabelecer um contexto social adequado e que ofereça suporte ao paciente de modo que este possa participar das decisões, tirar dúvidas e ser ouvido, bem como responsabilizar-se por seus atos. (Paranhos; Albuquerque, 2018, p. 41-42) - grifo do autor.
}

Para essa abordagem das necessidades do idoso a partir de uma autonomia que se dá de forma relacional, vale resgatar o quadro de vulnerabilidades proposto por Ayres (2009c), em que 
O conceito de vulnerabilidade designa um conjunto de aspectos individuais e coletivos relacionados à maior suscetibilidade de indivíduos e comunidades a um adoecimento ou agravo e, de modo inseparável, menor disponibilidade de recursos de toras as ordens para sua proteção. (Ayres, 2009c, p. 447)

Assim, o tipo e grau de vulnerabilidade revela arranjos singulares de aspectos individuais (intersubjetivos), sociais e programáticos.

A dimensão individual da vulnerabilidade (individual que, como apontado acima, é sempre entendida como relacional), refere-se a situações e práticas que podem levar alguém a experimentar um adoecimento, agravo ou condição indesejável, ou, em sentido oposto, aos meios de evitá-los. Engloba aspectos físicos e do modo de vida. Valores, interesses, crenças, desejos, conhecimentos, atitudes, comportamentos, relações familiares, afetivas, redes sociais e situação profissional, material, psico-afetiva e de saúde são aspectos a serem considerados nessa dimensão.

A análise da dimensão individual reclama imediatamente a necessidade de avaliação social, já que a intersubjetividade que a constitui está sempre contextualmente localizada. Normas sociais e religiosas, referências culturais, relações de gênero, raça e inter-geracionais, discriminação, emprego, salários, suporte social e acesso à saúde, educação, justiça, cultura, mídia e lazer, além de participação política e cidadania, são aspectos que interferem nas possibilidades de um indivíduo ter acesso, compreender e implementar ações voltadas à sua saúde.

O plano da dimensão programática, por fim, remete a como as instituições, nos determinados contextos sociais, atuam como elementos redutores, reprodutores ou capazes de aumentar as condições de vulnerabilidade de comunidades, grupos sociais e indivíduos nos seus respectivos contextos. São aspectos considerados nessa dimensão as políticas (tanto em definição quanto em planejamento e execução), a articulação multissetorial, acesso e qualidade dos serviços, a promoção e o respeito aos direitos dos cidadãos, dentre outros.

Esse referencial se mostra potente para abordar a questão da relação entre autonomia e saúde do idoso também porque, como a própria ideia de 
autonomia, assume-se que as vulnerabilidades a qualquer situação ou agravo à saúde têm um caráter relacional (só podendo ser compreendidas no âmbito das relações intersubjetivas), são multidimensionais (em uma mesma situação o que é um fator de vulnerabilidade a algum agravo pode ser de proteção a outro), instáveis (suas características e intensidades mudam constantemente ao longo do tempo) e não unitárias (não se é ou não vulnerável, pode-se estar vulnerável em diferentes graus) (Ayres et al., 2003). É com base nessas afinidades que procuraremos categorizar nos termos das três dimensões interpretativas de vulnerabilidade as principais dificuldades enfrentadas $e$ as facilidades identificadas na atenção ao idoso pelas equipes no trabalho da UBS.

\subsubsection{Autonomia, cuidado e principais desafios e facilidades da atenção ao idoso na Atenção Primária à Saúde}

\subsubsection{Dimensões Individual e Social}

\subsection{Adesão}

Segundo o Ministério da Saúde a "adesão ao tratamento tem sido definida como a extensão na qual o comportamento do paciente coincide com o plano de cuidados acordado com os profissionais de saúde" (Brasil. Ministério da Saúde, 2016, p. 15). No contexto do método clínico centrado na pessoa e mesmo na linha de cuidados para a pessoa idosa, preconiza-se o desenvolvimento de projetos terapêuticos singulares entre o profissional e o indivíduo. Desta forma, é necessária uma pactuação, ou uma "aliança terapêutica", entre usuário e profissional, com reconhecimento de responsabilidades para todos os envolvidos no processo (Marques; Petuco; Gonçalves, 2010). Nas narrativas dos profissionais da UBS, a "não adesão" (ou "má adesão") aparece principalmente como o não querer seguir as propostas, teimosia ou mesmo as negativas dadas pelo usuário ao profissional de saúde.

Olhando pelo lado dos insulino-dependentes a gente acaba sofrendo esse impacto no cuidado do idoso porque a gente orienta, a gente ensina, a gente vai até a residência porque muitas das vezes não tem 
alguém para auxiliar. Alguns são muito dificultosos porque são muito teimosos, são teimosos "não vou fazer", inclusive teve um dia desses que eu fui na casa de uma paciente que eu vou sempre e eu sempre oriento, é insulino-dependente, e falo para ela "olha, você vai precisar fazer três vezes por dia a medição do dextro que é importante para a senhora saber o que está acontecendo, se precisa aumentar a dose, se precisa diminuir", ela fala "tá bom", daí quando a gente vai fazer o descarregamento do aparelho a gente vê que ela não fez nem 20 vezes. Então esse paciente acaba sendo descompensado porque às vezes acaba comendo o que quer comer, faz o que quer fazer e às vezes não segue essa orientação. Para mim isso é muito impactante porque essa pessoa não está aderindo, para ela conseguir viver um pouco melhor, ela não está aderindo à forma de tratamento que está sendo imposta pelos profissionais. Então ela vem até o posto, a gente orienta, pede para ela seguir, acaba pedindo para ela cortar algumas coisas, ou diminuir, porque às vezes a pessoa é teimosa.(Diego, técnico de enfermagem).

O que é o desafio para nós da saúde? Os "nãos". E o "não" é dado pelo idoso porque ele tem autonomia, ele tem esse direito de escolher o "não", ele não quer se tratar, ele não quer tomar o remédio, o que ele quer é morrer. A gente vai tentar, claro, será que não tem um componente de saúde mental que está atrapalhando essa decisão dele? É o nosso papel. O nosso papel a justiça nos cobra.(Débora, assistente social)

Então, é esse paciente que não adere à consulta, não adere ao tratamento. Esse é muito difícil. Paciente que fala que vai fazer tudo direitinho e não faz. Paciente que tudo que o médico pede, ele não faz e depois fala "Não melhorei." Então esses acho que "é" os mais difíceis pra gente tá podendo ajudar. Tem casos que você chega a falar "Ah, meu Deus, eu já tô desanimando. Já não tenho mais força. Não tenho mais da onde buscar força pra tá ajudando, né?" (Dulce, técnica de enfermagem)

Então você percebe que ela está ficando com umas dorezinhas aqui e ali por falta de cuidado e ele tem todo o amparo em casa, tem duas cuidadoras, tem estrutura, tem convênio e ela nada e aí você se sente impotente "como vou ajudar essa pessoa se ela não quer ajuda? [Se] Tem medo?” Não sei. (Carla, ACS)

A maioria a gente teve insucesso, porque por mais orientação que a gente dê o paciente às vezes não segue, mesmo a gente falando da importância. Um caso que marcou talvez tenha sido o de uma senhora que a gente foi fazer uma visita, ela já era sub-dependente, mas tinha um grau de mobilidade bom, saía, e na visita a gente orientou com relação a risco de queda, tirar o tapete, aquela coisa toda, e não foi seguida a orientação e aí uma semana depois caiu, teve uma fratura de fêmur, e a partir daí ela evoluiu pessimamente, ficou acamada, a parte 
cognitiva também piorou muito e veio a falecer alguns meses depois. Mas foi bem cuidada pela família, mas mesmo assim... Mas no geral eles tendem a não obedecer muito (Fernando, MFC).

Teimosia, são muito teimosos, você fala uma coisa, explica uma coisa, eles não entendem, ou fazem o contrário. São muito teimosos, acho que todo idoso é teimoso e não sou eu que vou mudar, é o jeito que eles estão acostumados. (Berenice, ACS)

Apesar de os termos "teimosia" ou "obediência" serem descritos nas narrativas, é sabido que a maior facilidade ou dificuldade de adesão a uma proposta envolve diversos fatores. Baixa condição socioeconômica, desconhecimento em relação aos benefícios ou indicações do tratamento, quantidade de medicações, debilidades na rede de fornecimento das medicações, abuso de substâncias, presença ou não de apoio familiar, analfabetismo ou condições precárias de estudo, crenças, mitos e tradições influenciam na decisão de seguir ou não as recomendações (Freitas; Nielson; Porto,2015; Brasil,2018; Marques; Petuco; Gonçalves, 2010). Em relação especificamente à subutilização de medicamentos, dados do ELSI-Brasil ${ }^{23}$ (Loyola Filho et al., 2018) indicam que cerca de 10,6\% dos idosos não utilizam de forma adequada (ou completa) os medicamentos prescritos por motivos financeiros, estando relacionada esta dificuldade à maior idade, sexo feminino $\mathrm{e}$ pior condição socioeconômica, à frequência com a qual o indivíduo é orientado sobre a doença e o tratamento, ao número de medicações utilizadas, à qualidade da atenção (em geral, com maior adesão quando assistidos na saúde suplementar),à pior autopercepção da saúde e à depressão, apontando para o caráter multidimensional e complexo relacionado à não adesão.

Nos relatos, de fato fatores como analfabetismo, baixa condição socioeconômica, crenças e desconhecimento ou mesmo esquecimento são

\footnotetext{
${ }^{23}$ ELSI-Brasil é o Estudo Longitudinal da Saúde dos Idosos Brasileiros que é conduzido a partir de amostra nacional da população com 50 anos ou mais. Faz parte de um esforço internacional pertinente à realização de estudos longitudinais de grandes bases populacionais sobre 0 envelhecimento nas Américas, Europa e Ásia. Essas pesquisas são denominadas Health and Retirement Family of Studies de forma genérica e abordam os determinantes sociais e biológicos do envelhecimento, além das consequências individuais e para a sociedade dessa transição demográfica. Possui apoio de pesquisadores de instituições acadêmicas nacionais e internacionais, gestores do Sistema Único de Saúde e é financiado pelo Ministério da Saúde.
} 
apresentados como envolvidos na dificuldade de adesão, em especial aos medicamentos.

Mas restrição também tem o idoso que não sabe ler, uma das maiores restrições que a gente se depara, não sei se você foi à casa da dona Dirce, foi na casa da dona Dirce? Então, tem um quadro de medicação, não sei se ainda está assim, tem um sol, então está dia, tarde e noite, não sei se eles colocaram porque é o PAl que acompanha, eles fizeram uma tabela, aí segunda, terça, quarta, quinta, sexta, sábado, domingo, aí vai e volta, as medicações, então eles têm essa dificuldade também, eu entendo como uma limitação, porque não consegue ler e pode ser que faça coisa errada, também tem isso (...)

Algumas palestras foram feitas por causa disso, porque tem umas pessoas que não tomam anti-hipertensivo, a gente pergunta "por que você toma remédio?", "ah, porque o médico passou", mas não sabe de fato qual o benefício que o remédio vai trazer para ele e, porque ele está usando o remédio. Muitas das vezes eles vêm aqui, o médico receita, explica, mas depois eles esquecem tudo e acabam "hoje eu tomo, amanhã eu não tomo". (...)

Muitos desses idosos não conseguem acompanhar o que a gente fala, não conseguem ver de fato o que é verdadeiro para eles ali. Tem uns que misturam religião "não, não vou tomar não porque Deus me cura", eu falo "amém, se você acha que Deus te curou, amém, mas faça exames, se não está então toma remédio", então a gente acaba respeitando a religião, mas sempre ponderando "não, você precisa tomar, tal" e às vezes eles acabam ficando assim, à mercê e fazendo o que dá, porque às vezes eles queriam fazer mais, mas não podem(...) "Mas não adianta eu fazer, eu faço o que vocês pedem, mas sempre está alto, sempre está alterado, nunca está baixo, então eu vou fazer do meu jeito", aí muitas pessoas acabam intervindo, que não são da saúde, acabam falando para ela tomar não sei o que lá da babosa, suco de babosa, um negócio assim, outros falam para tomar o caldo do quiabo e acaba não achando o que é certo o que a gente está instruindo a fazer, e às vezes acha que é certo o que eles estão falando. Uns falam que tomou e nunca mais precisou tomar insulina, então na cabeça deles, esse povo mais antigo, é um tipo de paciente que tudo é natural para eles, então às vezes ele acaba sendo influenciado. Agente acaba orientando, eles às vezes seguem, depois param de seguir, falam "ah, não está funcionando, mas do outro jeito o outro falou que dá, funciona", e acaba fazendo essa comparação e a gente acaba vendo que está indo bem, que está indo para outro caminho, não é o caminho, mas a gente tenta trazer para o nosso lado que o lado mais prático, é o lado da medicina, é o lado que realmente vê as funções e tenta explicar.

(...) Muitos falam que recebem salário mínimo, que às vezes têm que comprar remédio, muitas vezes o remédio não tem aqui (Diego, técnico de enfermagem) 
Tem muita gente que não sabe ler. Então, isso é um problema. Você tem que ficar mais em cima. Tem paciente que eu vou lá, arrumo direitinho os exames, por ordem de data, o remédio. Aí na semana seguinte, ele vem e fala que ele não sabe onde tá mais nada. Então eu acho que essa capacidade dificulta muito. (Martha, ACS)

Durante observação participante de ambulatório de geriatria, certo idoso explicou que não seguia as recomendações por não conseguir retirar as medicações e não ter condições de comprá-las. Além disso, a equipe gostaria de encaminhá-lo para a atenção secundária, mas o idoso não teria quem o acompanhasse. Neste caso, e em tantos outros, fica evidente a etiologia multifatorial da adesão e a interconexão a vulnerabilidade individual, social e mesmo programática.

Ao se colocar em evidência a capacidade de decisão, alguns idosos manifestam maior tranquilidade quanto à não adesão a algumas orientações no campo da saúde. Em estudo desenvolvido em uma Unidade de Saúde da Família sobre adesão ao tratamento pelos idosos, as autoras apresentam, dentre outros fatores, a questão cultural como um dos relacionados à não adesão. Segundo elas "este fator inclui a percepção sobre a doença e a necessidade ou não de realizar o tratamento" (Marques; Petuco; Gonçalves, 2010 , p. 272). Em alguns dos relatos, a percepção sobre o próprio corpo, crenças pessoais, ou entendimento das suas limitações transparecem como aspectos que influenciam o seguir ou não as orientações. Além disso, o não entendimento do benefício ou a dúvida quanto à necessidade da medicação também apareceram como influenciadores da decisão. Para os idosos, ao contrário de para os profissionais, a não adesão, quando por esses motivos, é vivenciada com tranquilidade.

Em compensação a doutora G. me passou Atenolol, mas eu não tenho pressão alta e o Atenolol me derruba um pouco, mas eu tomo, diz que tem que tomar todo dia, mas de vez em quando eu tenho um pouco de taquicardia, quando eu faço muito exercício me dá um pouco de taquicardia, ai eu tomo, mas diz que tem que tomar todo dia, mas às vezes eu não acho necessário, pode tomar de vez em quando, quando a gente sentir ou deve tomar todo dia? (Carmen, 90 anos). 
"Fiz tudo que o senhor mandou", mas alguma coisa que eu achasse que estava errado..., mas eu não fazia nada de errado, sempre fiz tudo direitinho, mas às vezes "ah, isso aqui não está me fazendo nada", você encosta (...), mas ele também não conhecia meu organismo direito para me dar o que eu queria. A gente toma alguns remédios que não fazem bem. Entretanto, eu não falava nada (...) Mas se tiver que fazer eu vou fazer, já que não mudei muito minha alimentação, então ele fala assim "não adianta falar com a senhora que a senhora fala que sim, mas não faz nada que a gente manda". Então eu não faço. Eu faço tudo da minha cabeça... (lara, 84 anos)

Não, eu não sigo à risca, porque tem coisas que eles falam "tem que ser só isso", eu falo "gente, se eu viver só de folha eu vou ficar doente (...) Eu procuro não seguir à risca, mas eu procuro fazer o melhor que eu puder. (Ivete, 75 anos)

Não adianta ele falar para mim não fumar, eu vou fumar, por isso eu prefiro não falar, eu não falo o que eu não quero. $O$ que eu não quero escutar, eu também não deixo saber. Adianta falar? Não adianta. Meu irmão fala "tem que parar de fumar" então eu falo "parei de fumar", mas não parei. Eu sei que faz mal para a saúde, to sabendo. Daqui nada se leva, se dá prazer... (Sônia, 74 anos)

Eu tenho uma caixa de comprimido que eu vou jogar tudo fora, já está vencido. Eles me davam aqueles comprimidos para tomar. Chega aqui eu não tomo. Tomo não. Porque a pessoa que vive no remédio morre mais depressa, pode crer que é isso aí. A pessoa que vive mais no comprimido e no remédio, morre mais depressa. (Joaquim, 89 anos).

A abordagem para adesão e casos de abandono do tratamento deve ser centrada a partir da realidade da pessoa, levando em consideração aspectos éticos importantes e peculiaridades da doença (Brasil. Ministério da Saúde, 2016). Para as equipes, as dificuldades em relação aos "nãos" ou não adesão também perpassaram as condições de isolamento social ou falta de apoio familiar, em especial quando para além da adesão a medicações. Tais limitações ao cuidado, dada a sua grande expressividade nos relatos, será abordada isoladamente.

\subsection{As morfofuncionalidades}

No campo da morfofuncionalidade, as dificuldades mais comumente encontradas, pelos relatos da equipe, são as de marcha ou de locomoção. Para além da limitação física, alguns membros da equipe identificam situações do 
contexto da cidade, como violência e pouca adaptação dos espaços urbanos (e.g. tempo do semáforo para pedestres) como fatores limitantes para a realização do cuidado, interferindo, por exemplo, na prática de atividades físicas ou na procura pela UBS, ao maximizar o grau de incapacidade gerada pela alteração locomotora.

Mais comum é a dificuldade de andar mesmo, né? A dificuldade de andar fora de casa. Dentro de casa, sim. Mas fora, eles reclamam muito pela calçada. Porque eles têm insegurança, né? Então muitos deles não conseguem, tem medo de cair. Então, eles reclamam muito é isso, andar, né? Fazer as coisas dentro de casa também, mas eu acho que a queixa maior é de caminhar mesmo (Dulce, técnica de enfermagem)

Basicamente é a parte motora, tem paciente que faz uso de andador, de bengala. Essa parte também que tem dentro de casa, que o paciente não deixa fazer, geralmente é por conta disso mesmo, desse esquecimento, então acaba sem fazer algumas atividades dentro de casa, como cozinhar, alguma coisa assim. Restrição de pegar ônibus, não pega sozinho, se não tiver um acompanhante, um cuidador, alguma coisa assim. (Diego, técnico de enfermagem)

Locomoção ou até... Nem sempre é locomoção. Às vezes, a pessoa não tem segurança de sair de casa. Têm pacientes que moram... A minha área é muito perto. Mas tenho pacientes que não vêm até aqui, porque tem medo de atravessar a avenida. Porque não se sente seguro. Porque não se sente protegido. Porque a própria atravessar a rua do farol que fica aberto 30 segundos, a pessoa tem medo de não dar tempo. Sim, são coisas tão simples, mas que limitam muito a pessoa idosa. (Andrea, MFC).

Talvez de andar sozinho, de não ter alguém para acompanhar em consulta, fazer seus afazeres, são idosos que insistem em andar sozinho para não preocupar seus familiares (...) a gente vê bastante 0 idoso que tem essa certa resistência porque ele não quer se entregar, então ele vem sozinho mesmo sabendo que é perigoso. (Martina, enfermeira)

Eu acho que mais, das funcionais, mais com relação a sair de casa, com relação à motora mesmo. Ah, antigamente saía para fazer caminhada, para fazer um mercado e aí a gente percebe que agora já não dá mais conta, teve uma ou duas quedas no último ano, então às vezes ela já está ficando mais dentro de casa, então a gente avalia mais assim. $E$ ter essa queixa funcional em relação às quedas mesmo. $\mathrm{E}$ parte que, como a gente falou, às vezes a parte funcional, motora 
está boa, mas a cognitiva não, então também acaba ficando mais em casa e perdendo a função por isso também. (Fernando, MFC)

Essa limitação também aparece como importante nos relatos dos depoentes idosos.

Eu tento fazer, eu tenho medo de andar, que caio... tem que estar sempre com uma pessoa, por exemplo, na hora que a Júlia sobe, para lavar roupa ou sair, eu não levanto da cama, eu tenho medo de ir até o banheiro sozinha, que eu posso cair, isso daí me deprime, o que eu faço? Fumo. (Rute, 90 anos)

Vou... eu não posso ir sozinho por causa da cadeira de rodas, não ando sem a cadeira de rodas, eu não posso usar a prótese devido a perna que ficou encolhida, então se eu colocar a prótese for andar eu caio. (...) Eu não vou de táxi não, se o moleque não pode eu não vou porque o taxista não carrega cadeira de rodas. Chaga lá e coloca uma cadeira de rodas ele briga na certa, não leva, é difícil.(Joaquim, 89 anos).

Entrevistadora: E sente falta de algum tipo de recurso que o município poderia te ajudar?

Sônia: Ah, sim poderia por um farol aqui para... a pior coisa que eu tenho é subir essa passarela, eu e a Maria, nós duas cansamos muito, muito. (Sônia, 74 anos - ao citar uma passarela que interfere na sua locomoção)

Por outro lado, ainda que posta como uma limitação comum, a dificuldade de locomoção ou as alterações motoras foram apresentadas como uma das práticas assistenciais de abordagem mais simples, com uso de recursos que possuem na própria unidade de saúde: a fisioterapia.

Ah, talvez algumas que se resolvam mais com a fisio mesmo. Que a gente tem um acesso fácil aqui à fisio, né? A gente tem dois físios bons. Tem alguns equipamentos. Então, às vezes, bastava só esse encaminhamento, essa avaliação. Porque tá com muita dor, né? Dor nas costas, tal. É uma dor crônica, tem escoliose, mas dá pra tratar essa queixa crônica e não chega a resolver $100 \%$, mas dá pra contornar bem o problema e ajudar, né? (Carolina, enfermeira)

Entrevistadora: Qual a limitação que você acha mais fácil do serviço lidar e conseguir resolver? 
Carla: Eu acho que quando é essa parte motora, que exige um físio, que eles têm a facilidade de vir aqui assistir às aulas eu acho que, não tão fácil, que nem esses que têm problemas no joelho e fala "ah, eu estou melhorando com aulas", então eu acho que deve ser mais fácil. (Carla, ACS)

Para outros profissionais, ainda foram citados, no campo da morfofuncionalidade, a incontinência urinária, a diminuição da acuidade visual (este também mencionado por idosos) e o déficit cognitivo ou esquecimento.

$\mathrm{Na}$ questão da perda urinária, isso aumentou muito. A gente vê que as incontinências são limitadores sociais, também, né? Isso acarreta a questão da gente pedir os insumos da fralda. Isso faz parte um pouco da política. (Fabiana, enfermeira).

A visão, né? Eles têm uma limitação, muitas vezes. O paciente, ele vai tendo a dificuldade da visão, dentro de casa mesmo. Então essa é uma das queixas que eu percebo que eles falam mais. Alguns casos. "Ah, não. Eu não tô enxergando direito. Então eu não consigo mais fazer as coisas." E o esquecimento, também. Então eu acho que essas são as limitações que eu mais observo. Esquece, esquece um fogo ligado. Tem a dificuldade da visão, dificuldade de fazer os afazeres de casa que não consegue mais, né? E eles reclamam muito de ausência de família, né? A gente tem muito paciente que mora sozinho, que continua sozinho. Então... (Dulce, técnica de enfermagem)

E mesmo quando estava com a cabeça melhor, de vez em quando olhava e entrava uma letra dava para ler alguma coisa, agora para mim não enxergo nem letra, a vista está muito ruim, já fiz exame, já operei essa vista. E agora essa aqui também está ruim. De vez em quando meu nome eu faço, mas tem horas que eu erro, eu não assino meu nome perto de ninguém, porque se eu erro tenho que corrigir, vou errar, então não assino, falo "não sei assinar", a pessoa assina para mim (Joaquim, 89 anos).

Pego a televisão, você tá vendo, tá se distraindo, você vai se embrutecendo intelectualmente, isso vai, por que mesmo vocabulário eu tô perdendo, porque ler eu não posso muito porque eu fiz esse... eu fiz esses óculos não faz 2 anos, já não estou enxergando, tô com dificuldade de enxergar. (Rute, 90 anos)

Entrevistadora: Quais as limitações, ou limitação, que você acha mais difícil de lidar, qual mais impacta seu cuidado no dia a dia?

Fernando: Com certeza é a parte cognitiva. Que a gente sabe que dependendo do tipo de demência ela vai evoluindo e não tem muito como brecar isso, acho que mais isso. Porque a parte funcional às 
vezes a gente consegue através da fisioterapia melhorar os casos até que razoavelmente.(Fernando, MFC)

O físico é muito mais evidente e mais geral do que, por exemplo, o declínio cognitivo, e você tem que lembrar que o que vem para a gente mais no posto é principalmente queixa de memória, pacientes muito multi-mórbidos, tendem a ser acompanhados por outras especialidades clínicas, mas o que mais chama a atenção para nossa avaliação aqui no posto em particular é queixa de memória.(Daniela, geriatra)

Segundo estudo derivado da base de dados do ELSI-Brasil, 23,2\% dos indivíduos com mais de 50 anos apresentam limitações para atividades básicas de vida diária, sobretudo em relação à transferência (avaliada pelo movimento executado para sair da cama e sentar-se em uma cadeira e vice-versa, relacionado à mobilidade) e para se vestir (Giacomin et al., 2018). Os problemas de locomoção são frequentes em idosos e podem decorrer não só de alterações próprias dos membros inferiores, mas também de déficit cognitivo e alterações de sensopercepção. Quanto à visão, é sabido que o envelhecimento está associado a diminuição da acuidade visual em decorrência de alterações fisiológicas das lentes oculares, de doenças da retina e de alterações do campo visual. Já a incontinência urinária é estimada como presente em torno de 30\% dos idosos não institucionalizados, mas normalmente não são referidos pelos indivíduos caso não interrogados diretamente (Sirena; Moriguchi, 2013). Em estudo que avaliou o perfil de idosos acompanhados pelo Programa Acompanhante de Idosos na Cidade de São Paulo verificou-se que $58.8 \%$ dos entrevistados apresentavam dificuldades de visão, 41,3\%, incontinência urinária e/ou fecal, 60,3\% algum sintoma de depressão, 55,8\% sinais de déficit cognitivo e $68,4 \%$ necessitavam de ajuda em pelo menos alguma atividade instrumental de vida diária (Andrade et al., 2020).

\subsection{Dependência, Solidão e Família}

Dentre os desafios referidos pelas equipes, várias narrativas remetiam a casos em que havia uma necessidade, pelo olhar da equipe, de maior suporte e 
o idoso preferia ficar sozinho ou não dispunha de família ${ }^{24}$ por perto, ou, por fim, a família não prestava a assistência conforme esperado.

... É sempre a questão do idoso que quer morar sozinho, que não aceita a ajuda dos familiares, que não percebe que chega uma hora que não consegue se auto-cuidar, essa descoberta, essa aceitação do paciente é a mais dificultosa. (Martina, enfermeira)

Idoso que mora sozinho. Acho que é o mais difícil de mexer. Que não tem o apoio de nenhum lado, de nada, de ninguém. É bem complicado. Mesmo tendo PAl, né? Programa de acompanhamento dos idosos... O idoso sozinho... (...) Então, o que mais aparece em casos de reunião de equipe é idoso que mora sozinho. (Carolina, enfermeira)

Essa falta de cuidador, em sentido de... A maior dificuldade, pra mim, é essa. Essa limitação da pessoa idosa sozinha e que tá ficando cada vez menos funcional. Pode ser por questão de autonomia física, motora, de locomoção, de mental, cognitiva. E a gente, muitas vezes, não tem... O grande trabalho com assistente social, por exemplo, mesmo assim muitas vezes a gente não consegue. Tem filas de esperas enormes pra ter acesso a uma instituição de longa permanência ou ter algum tipo de cuidado mais constante, nesse sentido, no próprio domicílio. Então a pessoa idosa sozinha e menos funcional e que tá ficando cada vez menos, é uma grande... Acho que é a maior limitação da assistência (Andrea, MFC)

Martha: A dona C., ela tinha uma infecção recorrente de urina. Ela tomava remédio aleatório, que eu não sei onde ela conseguia. Ela foi ficando cada vez mais resistente e, depois, ela ficou com tumor na bexiga, que diz que não era maligno. $E$, por fim, ela foi ficando debilitada. Ela chegou a ficar internada pra tomar antibiótico via oral. Depois ela veio pra casa. Mas ela já tava muito debilitada, ela não queria comer. Morava sozinha, porque não queria ninguém com ela. Os filhos cansamos de... O PAl, né? O PAl cansou de ligar pra vim. Porque ela não deu o telefone pra ninguém, dos filhos.

Entrevistadora: O PAI, agora, você falou o Programa de Acompanhantes de Idosos?

${ }^{24}$ Há diversas possibilidades de definição para família. Para Duarte YAO et al (2010) ela pode ser compreendida como um sistema dinâmico em interação dialógica que visa ajudar a pessoa a desenvolver uma presença afetiva, responsável e livre no mundo. É uma criação do ser humano que responde ao desejo de ter um grupo de pessoas que atue sobre interesses comuns e com um desenvolvimento afetivo, em que os afetos sejam recíprocos, para obter soluções para os problemas do ciclo vital. Trata-se de uma organização defensiva diante dos embates da vida de cada pessoa e do conjunto familiar como um todo amenizando os impactos das "crises". Esse sistema corresponde a uma rede de relações de parentesco cujo funcionamento depende da forma como essas relações se organizam. 
Martha: O Programa de Acompanhamento. A acompanhante conseguiu com a N., que era uma... que dizia que tava cuidando da dona C., conseguiu o telefone dos filhos. Mas os filhos não vieram.

Entrevistadora: Os filhos dela não moravam no exterior?

Martha: Nos Estados Unidos. Não vieram, nem... Aí ela foi ficando debilitada. Ela veio pra casa, pegou pneumonia. Aí internou de novo, ela emagreceu muito, muito, muito. Aí faleceu. Esse foi um caso difícil. Porque tudo que a gente tentou, tudo foi em vão. Esse caso foi o caso que me marcou. São duas idosas que moravam sozinhas. Ela e a dona Z. A dona Z. também morreu praticamente sozinha. Então são casos que não têm família e você chega num limite de você não ter mais o que fazer. Então cê fica na frustração só. (Martha, ACS)

O isolamento social. Então, a questão de não sair mais de casa sozinho, nem de ir na padaria, nem de ir no supermercado. Nem, às vezes, de descer no prédio e tomar um sol. Então o idoso fica bem restrito no lar. Sem muitas, sem ninguém pra contar, muitas vezes, né? Sem familiar, sem amigo. Acho que isolamento social é o pior, assim. (Fabiana, enfermeira)

Fernando: Era uma paciente que era rebelde, ela não tomava as medicações corretamente, então assim, foi bem complicado. Mesmo com o PAl, mas o PAl é aquela história, é um programa de atenção ao idoso, de acompanhamento ao idoso, mas não é um programa full time, então ele não tinha uma curadora, o que ela tinha era uma amiga, uma jovem, na verdade, que morava ali no prédio e que às vezes ajudava e tal, mas era o mínimo, né, ela precisava de muito mais. Então foi um caso que a gente não teve o que fazer. Aí nos últimos seis meses ela foi piorando e a gente pediu a internação dela porque a família não apareceu e, ao contrário, desapareceu depois que ficou sabendo, mas também todos esses meses o ministério [Ministério Público] acabou devolvendo o caso "ah, precisa mesmo", vai e volta, vai e volta, até que não precisa mais.

Entrevistadora: E qual era a vontade dela? Ela chegou a falar para vocês o que ela queria?

Fernando: Não, na verdade o discurso dela era um discurso de "ah, eu quero ficar aqui no meu canto e não quero fazer mais nada", basicamente o discurso dela era esse. (Fernando, MFC)

Não só os meus como os das outras meninas também falando, é tudo a mesma coisa, é o idoso sozinho, o filho e a filha não ajuda, mora um em cima, outro embaixo, tudo parecido, tudo a mesma coisa (Laura, ACS).

Para alguns profissionais, existe também parcela de famílias que prestam um cuidado em escala acima do que o necessário para o idoso. 
Engraçado, né? $\mathrm{Na}$ área, a gente os dois extremos. Ou os familiares são super cuidadosos, que até se intrometem bastante do cuidado do pai ou da mãe, né? Do idoso. Que até quando a gente vai aplicar algum teste, alguma avaliação ficam atravessando as respostas. Você vê que tá preocupado, tal. E tem o outro extremo que não quer nem saber. Então acho que os dois extremos são ruins também de lidar. Então acho que, claro de acordo com a autonomia também do idoso, deixar o espaço pro idoso responder, se cuidar. Deixar um pouco da autonomia dele prevalecer, o cuidado da saúde dele. Mas, também, sem abandonar, claro, né? A gente gosta, sim, que esteja presente. Mas acho que o mais difícil é o idoso que não tem ninguém mesmo, que a gente não tem acesso. Que você chega a ligar, pegar celular, tudo, marca e não aparece. Acho que é o mais difícil de lidar, esse idoso que não tem esse apoio. (Carolina, enfermeira).

Mas eu percebo também que não é só isso, é cultural, não é só equipe que quer impor, a família impõe com muito mais facilidade do que você imagina. Eu vejo famílias que "olha, você não vai mais dirigir, você não precisa", famílias que ajudaram a mãe a ser demitida que "já está ficando velha, demite aí, tadinha, deixa ela em casa". Eu vejo muita interferência da família colaborando para essa dependência. Não é que o idoso se torna dependente o tempo todo, porque facilita, a vida moderna que a gente tem, a gente tem horários reduzidos, trabalha 0 dia todo, chega em casa, então é muito mais fácil delimitar o idoso a algo para a tua vida, então "eu tenho esses horários, pai, então você vai fazer nesses horários, você vai deixar de fazer o que você gosta, você gostava de jogar bocha? Então desculpa porque eu tenho as minhas coisas para fazer e você não vai fazer mais". Eu percebo famílias que é muito mais cômodo deixar o idoso sozinho em casa, porque levar ele para atividades de socialização dá trabalho, eu vejo que boa parte dessa falta de autonomia, claro que não vem só da gente, já vem do núcleo familiar. (Débora, assistente social).

\section{Outro desafio relatado é o fato de a família apresentar expectativas para o} cuidado, diferentes das do idoso ou da equipe.

É um paciente idoso, um casal. A gente acompanhava mais por causa dele, do marido, que era acamado por causa de uma fratura de fêmur. Só. Ele não tinha nada. Nenhuma outra comorbidade. Uma fratura de fêmur operada. A cirurgia, não sei se deslocou, se é porque... Também isso tudo foi antecedente do nosso acompanhamento. Então eu não cheguei, não achei nenhuma documentação. Sei que ele acamou e fazia mais de dez anos que tava na cama, esse paciente. Mas ótimo. Estado mental ótimo. O último Mini Mental que eu fiz pra ele foi três meses atrás e deu 27. Assim, ainda brincava. A única coisa que a gente tava dando um antidepressivo por causa desse estado de limitação na cama, sem conseguir ver ninguém. Isolamento social total. E um estado de abandono da família que, progressivamente, piorou. A gente até... Esse também entrou no Ministério Público, chegamos até o Ministério Público para ter um cuidador, porque ele recusava usar 
fralda, por exemplo, e a esposa idosa com uma dificuldade visível importante, dificuldade de locomoção, muitas dificuldades, fazia tudo. Ela trocava o lençol umas quatro vezes por dia, porque ele fazia tudo na cama. E era ela a responsável da higiene dele, da limpeza das roupas, dos lençóis. Então, imagina o estado que viviam os dois. A gente conseguiu alimentação para os dois, Alimentação Sobre Rodas. Com o Ministério Público, conseguimos um cuidador pra ele. Só que a gente teve muita dificuldade. Tem o PAI para ela. Só que a grande dificuldade foi com a família. Uma filha fisioterapeuta. Então ela já tinha assumido o cuidado do pai. Tanto que ficou acamado. E o cuidado da mãe, com a geriatria, com a psiquiatria. Ela levava tudo pra fora, pro Hospital das Clínicas. Ela nunca deu acesso nem a equipe, nem a equipe do PAI. As medicações, as consultas que ela tinha lá, então acompanhamento extremamente difícil. A filha não morava junto. $E$ esse paciente em dois meses entrou provavelmente também num estado depressivo, porque a filha tirou completamente a medicação dele pra mãe, a esposa dele, não tomar medicação dele. Então ela não dava nem pra ele. Ele, eu não sei se foi por causa da depressão, não sei se foi por negligência do cuidador e da família, porque a equipe já viu várias bandejas inteiras do Alimentação Sobre Rodas dentro da geladeira. Já pegaram ele comendo café da manhã às três da tarde. Que ele nem conversava com o agente de saúde pela fome que ele tinha, voracidade que ele tava comendo. $E$ tentei ativar $E M A D^{25}$, mas não deu tempo.(Andrea, MFC)

Tem famílias que trazem uma queixa, que às vezes é uma queixa até válida, e dependendo da nossa orientação eles seguem direito, a gente consegue encaminhar juntos, vamos dizer. E tem famílias mais difíceis que às vezes 0 idoso, ele nem tem tanta queixa, mas às vezes tem família que nem entende como a Estratégia funciona, por mais que a gente explique, acha que tem que ter visita no médico toda semana, ou agente de saúde todo dia. Por mais que a gente fale "olha, só vem uma vez por mês", a gente sempre fala, e aí tem família que liga aqui "olha, o agente de saúde não está vindo", mas o agente está lá. Eu acho que isso varia muito. (Fernando, MFC)

Também é apresentada como limitação para a assistência ao idoso, o fato da família, às vezes, não compreender o que seria papel da equipe de saúde e da família.

As dificuldades com família, geralmente, é assim: quem vai cuidar, quem vai levar na consulta, né? Quem vai fazer, quem vai ser o

\footnotetext{
${ }^{25}$ EMAD: equipe Multiprofissional de Atenção Domiciliar, destinada a prestar cuidados considerados complementares aos realizados na APS e em serviços de urgência, bem como substitutivos ou complementares à internação hospitalar. Destina-se para casos em que os indivíduos que demandam a assistência domiciliar requerem cuidados mais frequentes (intervalos semanais ou menores), em quadros agudos ou crônicos agudizados, restritos ao leito, crônicos complexos ou que requerem maior uso de tecnologia como ventilação mecânica.
} 
responsável por isso? Muitas vezes, eles não enxergam isso, assim. O caso de um outro paciente que a gente tem que tem uma dificuldade pra deambular, que usa muleta. Também, a esposa não consegue levá-lo pra consulta. Ela não enxerga que aquilo é papel dela. Ela não enxerga que é papel do filho fazer. Ela pede que a equipe faça. Que a equipe leve o paciente, entendeu? Então essa transferência de responsabilidade pra equipe de saúde. Às vezes, a família faz isso. (Fabiana, enfermeira)

Tem idosos que é assim, eu converso com eles [familiares] também, "vocês têm que sempre estar de olho nele, ver quando é a consulta, os exames", ou se não têm filhos eu, sendo agente comunitária, eu devo solucionar tudo, e aí eu falo "não é assim, meu trabalho não é esse, vocês como família vocês têm que se preocupar". (...) Eles falam, onde eu estou eles falam "Olívia, ele está assim", eu falo "que que eu vou fazer, já falei com médico, ele já foi orientado para fazer um exame específico que deve ser feito e vocês não ajudam, não levam", "ah, você não tem uma ambulância para levar?", "não é assim, aqui não tem ambulância, aqui é encaminhado e vocês têm que levar". É assim, sempre. Aqui na Geraldo Buono [rua], a dona G. Falava "mas, Olívia, você tem que fazer alguma coisa, como vai ser feito agora? Ai que não vou poder levar, que esse dia não tenho tempo, que meu marido não quer levar de carro", parece que eles queriam que eu desse um jeito para poder levar (Olívia, ACS)

Mas é como eu falei, a família tem que ir atrás. E hoje eu acho assim que a própria família espera muito que o SUS vai atrás, entendeu? E nós temos muita ajuda do SUS, é só a gente querer. (Soraia, ACS).

Ai uma ajudava a outra, mas e o desejo do paciente? Como fica a autonomia? Aí a Débora veio, fez uma reunião familiar "olha, o desejo da paciente é esse, vocês querem fazer alguma conversa, alguma ajuda?", e a família queria que a gente procurasse um asilo para levar a mãe dela para mostrar e a Débora falou "isso quem tem que fazer são os familiares".(Martina, enfermeira)

Por outro lado, a família ser presente e vinculada a equipe é apontado como um dos principais facilitadores do cuidado do idoso.

Tem famílias que são bem ausentes, aí não tem jeito, mas no geral eles mais ajudam, mais se preocupam, tendem realmente mais a ajudar. Principalmente no caso de idoso que, por exemplo, tem um cuidador que é familiar ou até um que não é, mas que faz o acompanhamento direitinho, controla as medicações no dia a dia, normalmente segue direitinho as orientações, não tem tanto problema. (Fernando, MFC) 
Porque quando o idoso tem gente do lado ajudando é outra história, assim. A família, ela se comporta de outra forma. O idoso está diferente, né? O seu estado emocional é diferente. Quando há uma conexão entre a família e o paciente ou amigo que cuida, o cuidador e o paciente. Quando ele tem, mesmo um cuidador e um familiar que não conecta, que não há relação, são como se ele tivesse quase sozinho. Então, independente de ter alguém fisicamente, é de fato ter essa conexão do cuidado (Fabiana, enfermeira)

Aquele paciente que vem sozinho e consegue se cuidar e a gente sabe que tem uma família grande e que a gente sabe que pode contar com essa família, eu acho muito bom quando eu percebo na consulta que o paciente está com dificuldade e vejo que ele não está conseguindo lidar com isso, só que por trás dele a gente sabe que tem uma família que cuida dele muito bem e repassa para a família. (Martina, enfermeira)

A questão familiar expressa-se, na prática, em conflitos que vão para além da mera presença ou ausência. Sua relevância é ímpar, já que se constitui, concomitantemente, como a principal fonte de apoio social e estresse pessoal. A família afeta a saúde da pessoa, que, por sua vez, afeta a saúde da família. Esta é o "local", por ser a fonte do material cultural e genético de uma pessoa, onde se aprende sobre saúde e doença e também onde a maior parte do cuidado é dado ou recebido no transcorrer da vida. Consequentemente, a família tem grande potencial como aliado na manutenção ou na recuperação da saúde de seus membros e é um importante apoio do profissional de saúde. Em nossa sociedade, quase toda família está envolvida com o bem-estar de, pelo menos, uma pessoa idosa (Asen, 2012; Duarte et al., 2010). Assim, para um olhar mais completo do indivíduo no estágio tardio da vida e seu cuidado em saúde é imprescindível avaliar sua relação com e sua inserção na família.

É importante considerar também que hoje vivemos alterações importantes na estrutura das famílias: a família extensa passou a ser nuclear (com pais e filhos) e houve redução no número de filhos (predomínio de famílias com três ou quatro elementos), há maior mobilidade dos filhos e há a inserção da mulher, que tradicionalmente ocupa o papel de cuidadora, no mercado de trabalho urbano. Estas mudanças interferem no potencial de ajuda familiar que apresenta menor disponibilidade para prover o cuidado dos membros mais idosos; o que pode impactar na sobrevida, com qualidade, dessas pessoas, além de gerar 
importante tensão na família por um cuidado prolongado a um membro doente (Walsh, 2001; Duarte et al., 2010). Os filhos adultos normalmente têm suas despesas drenadas com gastos com a faculdade dos filhos na época em que as despesas médicas com os pais idosos aumentam. A responsabilidade do cuidado que era de domínio tradicional feminino passa a ter concorrência com as preocupações profissionais, num momento em que o trabalho dessas mulheres se tornou essencial para manter um padrão de vida razoável nas famílias, em especial nas famílias divorciadas. Assim essas mulheres, no meio da vida, estão cada vez mais sobrecarregadas por exigências físicas e emocionais conflitantes (Walsh, 2001). Associadamente, as famílias com os idosos mais dependentes se deparam, em algum momento, com uma difícil alternativa: incorporar o idoso à casa de um filho; transferi-lo para uma instituição de longa permanência ou casa de repouso; deixá-lo viver só, apesar de suas limitações, ou contratar um cuidador para conviver e cuidar dele (Duarte et al., 2010).

A questão da dependência assume, também, um primeiro plano nas relações intergeracionais, na medida em que os pais que estão envelhecendo vivem - ou temem - um declínio em suas capacidades. As tarefas do estágio tardio de vida habitualmente já se entrelaçam com as preocupações específicas das gerações de filhos e netos. Contudo, podem surgir novos desafios, em especial pela crescente diversidade nos estilos de vida, dos padrões familiares e a tendência em se casar e ter filhos num momento mais tardio da vida. Uma das ferramentas utilizadas para abordagem familiar, o "Ciclo de vida familiar"26, face a essas peculiaridades da velhice, propõe algumas tarefas ou ações a fim de que essa crise esperada da família seja vivida até que se atinja um novo equilíbrio no sistema familiar (Brasil. Ministério da Saúde, 2013). Dentre essas tarefas, sugere-se que os filhos se permitam viver papel filial (ainda que 0 progenitor muitas vezes tenha um comportamento infantilizado, como nas demências) e que os adultos mais velhos aceitem de forma real suas limitações

\footnotetext{
${ }^{26}$ O Ciclo Vital ou Ciclo de Vida Familiar é um recurso voltado para abordagem familiar, com maior frequência utilizado na APS e que, particularmente, tem o seu uso estimulado dentro do campo da MFC. Nele são representadas as várias etapas pelas quais as famílias passam com suas características específicas e os principais desafios ou tarefas a serem cumpridas a fim de que se atinja um novo equilíbrio no funcionamento da família. O estudo do ciclo de vida permite que sejam observadas as dificuldades ou crises (previsíveis/normativas ou não previsíveis).
} 
e a ser dependente quando necessário. Walsh (2001), discutindo o ciclo de vida, alerta também que em alguns casos, um progenitor que está envelhecendo pode tornar-se muito dependente dos filhos adultos e que caso os filhos respondam de forma excessivamente responsável, em virtude de sua própria ansiedade, pode-se criar um círculo vicioso: quanto mais os filhos fazem pelo progenitor, mais desamparado ou incompetente este se torna, com crescentes necessidades, encargos e ressentimentos. Segundo o autor, propicia-se a criação de um ambiente de "super apego" e dependência ambivalente, que, para serem evitadas, tornam necessário o apoio do máximo funcionamento e competência nos membros mais idosos da família. Há limitações nas abordagens ao se tentar prescrever especificamente os percursos a serem escolhidos diante de uma dificuldade. Mas a ferramenta tem o seu valor na APS por estruturar em linhas gerais as características dos principais movimentos da família ao longo da vida, auxiliando os profissionais no cuidado a elencar algumas ações que podem ser avaliadas e sugeridas conforme cada caso e contexto.

A família, ou o cuidador informal também provê, no meio brasileiro (Giacomin et al., 2018) e entre os entrevistados, o principal cuidado com os seus idosos.

Outra fonte de dificuldade que merece ser destacada pela narrativa de alguns profissionais, é a questão do "estresse do cuidador". Condição sabidamente relacionada a diversos prejuízos na qualidade de vida de quem fornece o cuidado e que pode em alguns momentos ser agravado pela história de vida do idoso, dificultando a realização do cuidado por um familiar (como no próprio relato das duas agentes comunitárias que também eram cuidadoras em tempo parcial de alguém em sua família).

Eu acho que na área é muito mais fácil cuidar das pessoas de fora do que das de dentro de casa. (...) Lá fora, não sei se porque a maioria tem dinheiro, sabe se cuidar, sabe se divertir, sabe fazer todas as coisas, na minha casa a gente não tem condições... tem aquelas condições básicas (...) é difícil, quando a gente fala que vai cuidar, a gente cuida, mas, ao mesmo tempo...Eu deixei de fazer muita coisa por causa dele (...) "põe ele numa instituição", mas eu não tenho coragem. Só que eu tinha que fazer um monte de coisa para mim, as minhas coisas, eu não faço mais, é tudo para ele. (Berenice, ACS) 
Porque ela exigia muito da gente, onde a gente não podia. Porque, hoje, todo mundo, toda família tem uma vida muito, muito assim corrida (...). Porque o idoso que você conhece, a sua família, você sabe o gênio dele, o que ele fez, você entendeu? O que ele fez no decorrer do tempo da vida. Então você viu. E o idoso que não é da sua família, você não viu. Você escuta a família falar. Mas ele não é... Ele com você não é aquilo que a família fala. Porque o idoso com a família, ele age de uma maneira diferente. (Soraia, ACS)

A gente também tem um olhar com relação ao cuidador, porque a gente sabe de todos os malefícios que pode causar o cuidador, e nas visitas a gente sempre procura fazer a avaliação do cuidador, se tem alguma angústia e do que precisar a gente deixa à disposição no posto. (Fernando, MFC)

Tentar trabalhar o estresse do cuidador é uma coisa super difícil de trabalhar porque aquela pessoa tenta fazer o máximo de si, só que ela chega num ponto em que ela não suporta mais aquilo e enquanto política pública a gente continua dizendo para ela "você vai ter que suportar, querida, porque não tem nada que vai te dá conta, a gente tem o PAl que vai no máximo três vezes por semana, mas a gente tem a ILPI [Instituição de Longa Permanência para Idosos], mas a ILPI está sem vaga, o grau de dependência dela não entra em ILPI, então, querida, força", é horrível. (Débora, assistente social)

A importância do olhar para o cuidador é reforçada na narrativa de Soraia quanto à sua experiência ao cuidar de seu avô (que faleceu com mais de 100 anos) e de sua sogra.

Soraia: O que me faltou e faltou pra E. [cônjuge] aqui, foi uma psicóloga, aquelas terapias que eu tive no tempo do meu avô, que eu fiz a terapia. Era quase duas horas que tinha de terapia. Então a gente chorava, a gente aprendia. Essa terapia faltou. Porque eu acho que toda pessoa que cuida de idosos, ela precisa de muito mais ajuda do que o idoso. Muito mais ajuda. Aquela pessoa que ajuda da sua própria família.

Entrevistadora: Então hoje pra você uma coisa que seria importante ter é isso?

Soraia: Eu acho. Eu tive muito apoio, muito apoio nesse um ano e dois meses que a minha sogra ficou na cama debilitando, que ela quebrou $o$ fêmur e, logo em seguida, ela já tá tava com Alzheimer, veio Alzheimer pra valer. E eu acho que necessitava, pra mim e pro E., porque a gente teve uma parte, assim, da vida da gente que a gente abandonou. (Soraia, ACS).

De fato, as consequências negativas na saúde física e mental do cuidador familiar têm sido bem documentadas. Além da sobrecarga objetiva e subjetiva, o 
cuidador informal apresenta alterações na qualidade de vida. Durante a trajetória da doença da pessoa que recebe o cuidado, o comportamento físico e emocional do cuidador é afetado, principalmente com o aumento dos sintomas e da necessidade de dedicação. O que pode resultar em isolamento social e depressão do cuidador associado ao menor tempo para descanso ou outras atividades sociais, perda de oportunidades (principalmente profissionais), desestímulo à reprodução e outros problemas (FRIPP, 2012; GIACOMIN et al., 2018). A depressão e a ansiedade no cuidador podem desencadear depressão e ansiedade no paciente e vice-versa; ou seja, se a família é afetada pela doença, as reações familiares também afetam o paciente. $O$ cuidador familiar tem 0 dobro de probabilidade de desenvolver doenças mentais ou físicas se comparados a não cuidadores, redução de cerca de dez anos na expectativa de vida e também se expõe a uma necessidade de cuidados de longa duração (Fripp, 2012; Giacomin et al., 2018; Duarte et al., 2010).

Se as relações com a família (incluindo o cuidador) ou a falta de família, são delicadas, a questão da solidão ou do isolamento social foi apresentado também de forma marcante. Para alguns idosos e profissionais, a ausência de companhia foi indicada como um dos sinais do envelhecimento, conforme apresentado anteriormente.

Em algumas situações uma procura maior pelos serviços de saúde decorre do isolamento social, segundo experiência de alguns profissionais.

A demanda para os serviços de saúde, muitas vezes, esconde uma demanda muito mais profunda embaixo, né? Que é uma demanda de atenção, de cuidado da família, não do serviço de saúde. Mas acaba jogando pros serviços de saúde, porque acaba se manifestando com queixas de saúde. Que não são realmente, são demandas de atenção, pessoa que tá ficando muito sozinha, que tá se sentindo negligenciada pela família. (Andrea, MFC)

A gente sempre pergunta. Independente se aplica a AMPI [Avaliação Multidimensional da Pessoa Idosa da Atenção Básica] ou não, eu pergunto nas minhas consultas se ele tá feliz, se tem alguma coisa pra melhorar, como que ele enxerga a saúde dele, se tá legal, tá boa. Se tá melhor que as pessoas da idade dele, né? Da mesma faixa etária. Tentando sempre dar valor a essa parte também. Porque não é só pedir um monte de exame de sangue, encaminhamentos e pronto, né? Ver se realmente, às vezes, tem muitos, né? Que vêm só pra 
conversar. Estão ótimos, assim, tão compensados, né? Vem só pra rotina. A cada seis meses, até... Às vezes, não chega a um ano, mas passa de seis meses, oito meses. E eles vêm só pra conversar. Que, às vezes, são muito sozinhos, né?(Carolina, enfermeira)

Além disso, a situação do isolamento é notada como frequente por alguns profissionais das equipes e em alguns casos aparece associada a violência.

Eu acho, assim, eu percebo na minha área, na minha área tem muito idoso abandonado, entendeu? Abandonado, porque eles mesmos querem ficar abandonado. Idoso que eu falo, assim, a partir de 60 anos, tá? Eu vejo que a necessidade de uma pessoa a partir dos 60 anos é ter mais apoio. Apoio, assim, reunião entre amigos, entendeu? Um esporte, uma atividade. E eu não vejo idoso, eu vejo essa pessoa a partir dos 60 anos, muitos, sendo abandonados e sendo esquecidos (Soraia, ACS).

Martha: Então é muito idoso e você não tá dando conta. Eu tô com 230 famílias e a maioria é tudo idoso.

Entrevistadora: $\mathrm{E}$ você nota que tem família junto desses idosos ou a maioria mora sozinho?

Martha: A maioria mora sozinho. (Martha, ACS)

Quando a gente pergunta sobre isso, muitos idosos com problemas de depressão porque se veem sozinhos, se veem sem planos para 0 futuro, então a gente tem um cuidado em relação a isso. (Fernando, MFC)

Então, por exemplo, esse casal que é um que mexeu muito com a equipe, assim, que veio... A gente veio arrastando esse caso já desde a época do J. Antes da $\mathrm{C}^{27}$, sabe? Logo que eu entrei, assim. Mais de dez anos arrastando o caso. Então marcou muito todo mundo. A equipe inteira mesmo sendo a área, cada agente tem uma área de atuação né? Mesmo sendo da área de outro agente, os outros também se comoveram com esse caso e a queixa principal é "Tô sozinha". O idoso, lá, "meu esposo me bate", mesmo acamado. "Minha filha não vem". "Minha filha tá me roubando." Então, era sempre questão familiar. Que queria que tivesse uma família que apoiasse. Que desse suporte mesmo, né? Porque se tivesse essa filha presente, que fosse uma vez por semana, já resolvia o problema. Mas não tinha. Ela ia lá pra pegar dinheiro. Uma vez por mês aparecia. Então é mais a questão familiar que eles falam bastante, que queria, mais o apoio da família, estar presentes nas festas. "Ah, porque eu participava dos natais, das viagens. Não participo mais. Me deixaram aqui." Então, faz parte de

${ }^{27} \mathrm{~J}$. e C. são médicos que trabalharam na equipe antes da médica atual. 
muitos idosos esse projeto de fazer [parte da família]. (Carolina, enfermeira)

\section{Para os idosos, a solidão e o isolamento social são também marcantes na} experiência do envelhecimento.

O que faz falta pra mim, é gente, gente dentro de casa. (Rute, 90 anos)

Eu fico magoada com certas coisas, porque a vida é meio difícil. Você ajuda uma pessoa tudo, depois tem uma família, um conhecido... não tem ninguém que vem falar para você "quer que eu te faça um arroz?", entendeu? Isso me magoa, então acho que eu não preciso de ninguém, porque mesmo não podendo eu vou fazer, nem que seja para queimar, mas eu faço. (lara, 84 anos)

É o Centro Dia para idoso, passo o dia todo lá, e me sinto muito bem porque as meninas cuidadoras são muito boas, e os idosos gostam muito de mim, logo que eu entrei todos escreveram uma cartinha de boas-vindas para mim, mas quando eu vou chegando em casa eu começo a ficar deprimida, (...), mas eu não quero dar trabalho porque às vezes eu não me sinto bem, eu já fui para pronto-socorro sozinha, chamo o SAMU [Serviço de Atendimento Móvel de Urgência], vou pro pronto-socorro sozinha, problema de depressão, de preocupação, isso depois que a L. morreu, porque só eu me voltei a mim quando ela morreu.(Carmen, 90 anos)

Os filhos abandonaram ele aí, não aparece nenhum dos filhos, então eu tenho muita amizade com ele. Tenho dó dele, é muito sozinho. Os filhos abandonaram por causa da bebida. Os filhos não ligam para o pai de jeito nenhum, eles estão tudo bem de vida. $O$ pai está quase cego e não ligam, tem glaucoma, não sara, está pingando colírio direto. Tenho muita amizade com ele, é a única pessoa com quem estou sempre conversando. (Joaquim, 89 anos, falando sobre o vizinho com quem conversa).

Tínhamos 14 irmãos, desses 14 só tem eu de resto, não tem mais ninguém da família, só tem sobrinhada que está tudo perdido por aí, eu nem conheço. Entretanto, eu tenho 4 bisnetas que eu nem sei que cor que é, nem sei se é branco, se é azul, se é preto, se é amarelo... eu sei que meus netos era tudo branco, tudo loiro, moram lá em Campos do Jordão, mas não posso viajar mais, eu machuquei a coluna, quando eu vou daqui lá no posto, quando eu volto, tem que ficar deitado esticado para melhorar a coluna. Fico 2, 3 dias deitado sem poder me mexer, só ficando na cama. (Joaquim, 89 anos)

Entrevistadora: E a senhora acha que tem alguma coisa que atrapalha pra alcançar esses sonhos de paz e saúde?

Dirce: Tem a família, né? Porque a família não... Mesmo o filho meu, digo logo assim, meus filhos mesmo só quem frequenta aqui. Então é 
feriado, entra dia santo, entra natal, entra ano novo, entra tudo. Não aparece. Às vezes, aparece um, chega e vai embora. Só isso. Nunca se dão presente, nunca traz um presente pra mim. Isso que eu tenho desgosto. Tanto que eu sofri pra criar esses filhos e nem no dia assim aparece um presente pra mim. (...) Ninguém pergunta se eu tô com fome, se eu tô doente, se eu tô sentindo alguma dor. Se eu tenho o que comer. Se eu tenho o que vestir. Se eu tenho o que calçar. Nada. E o juiz? E o juiz, às vezes, pediu pra mim processar os filhos. (Dirce, 82 anos)

Ah, porque quem que gosta de velho, filha? Ainda mais sem dinheiro. Só com o dinheirinho contadinho pra viver? Você se tiver dinheiro pra ir pra uma churrascaria e convidar os amigos, tá cheio de amigos. Se não tiver o dinheiro pra segurar uma situação dessa, você não tem amigos (...) Eu tive numa situação boa até uns dez anos atrás, entendeu? Então favoreci muita gente. Deixei muita gente bem. Só que hoje não tenho resposta, não tenho nem sobrinho, nem irmãos nada. Tá todo mundo de longe. Situação também tem que entender que é difícil, né? Mas o ser humano, ele é assim. O ser humano, ele é alongado, ele não tem muito amor ao próximo. Tem amor ao lado material. (João, 81 anos)

Em reunião de equipe, a geriatra afirma que "morar com alguém é fator de proteção"28. Na fala de Ivete, essa proteção aparece como sendo um estímulo a se manter ativa. Já na narrativa de Sônia, que também apresenta bom suporte familiar, as relações familiares foram relatadas em vários momentos como fonte de deleite.

A gente vive assim, uma vida humilde, mas, graças a Deus, muito unidas. Acho que isso também me faz ter forças para trabalhar, porque quando você tem uma vida agitada, sem ser compreensiva, quer ter muitas pessoas, na minha idade, não consegue trabalhar não por não ter forças, mas por não ter um objetivo para fazer alguma coisa, ou quer parar logo, ou, porque aposenta e acha que não precisa mais, ou, porque aposentou, parou. (Ivete, 75 anos)

Ah, eu me sinto muito bem quista, muito bem quista. Nossa família se dá muito bem todo mundo. (Sônia, 74 anos).

A literatura em geral diferencia solidão de isolamento social. Para alguns pesquisadores, o isolamento social é tido como um estado objetivo de mínimo contato com outros indivíduos e a solidão é definida como um estado subjetivo de falta de afeto e proximidade. Viver só não implica necessariamente solidão, já

${ }^{28}$ Notas do caderno de campo. 
que pessoas que vivem sozinhas podem possuir contatos frequentes e envolvimento social, por isso a distinção reforçada por alguns autores. Em outras situações, o indivíduo pode desejar ser solitário praticando um distanciamento voluntário, ao contrário da solidão (que é entendida como involuntária). Outros já definem a solidão como a discrepância entre as relações sociais reais e desejadas (Ong; Uchino; Wethington, 2016; Silva et al., 2014). Macedocouto e Silva Junior (2017), em estudo sobre o fenômeno da solidão, explicitam a dimensão ontológica da solidão resgatando-a a partir da fenomenologia de Heidegger. Nessa interessante aproximação, apontam uma reflexão da solidão "enquanto tonalidade afetiva que constituem o ser humano enquanto ser-nomundo e com-os-outros" (Macedocouto; Silva Junior, 2017, p. 7).

Silva et al. (2014), em trabalho que estuda sobre os sentidos atribuídos à solidão pelos idosos, identificam que

\begin{abstract}
Essas condições podem configurar parte da experiência de solidão como resultado da deficiência em um ou mais de tipos dos relacionamentos: apego (derivam o senso de segurança); integração social (advinda de uma rede de relações sociais); cuidado e dedicação (compromisso de uma das partes pelo bem estar da outra); reafirmação do valor (capacidade e habilidade para ser reconhecida); aliança (pactuação para assistir um ao outro) e orientação (quando recebe conselhos). Assim sendo, solidão compreende uma experiência emocional aversiva e estressante se associada a não existência, afastamento ou a perda de relações afetivas significativas. A mesma pode ainda ser associada à perda de papeis, afastamento, limitações físicas e financeiras além da morte de entes queridos da mesma idade. (Silva et al., 2014, p. 3)
\end{abstract}

Nos relatos aqui apresentados solidão e isolamento apresentaram-se, mais do que relacionados, sobrepostos. De forma que serão usados como sinônimos.

O isolamento social tem crescido (Lubben, 2017) e são apresentados como possíveis motivos a diminuição das taxas de natalidade e fecundidade, as mudanças nos valores familiares e do casamento (com aumento do número de solteiros e divórcios), as mudanças na organização da sociedade e das condições da vida familiar e profissional (dificultando a convivência, ainda quando sob a mesma casa), as alterações no padrão de solidariedade dos mais 
novos para com os mais velhos e mesmo a maior possibilidade de se viver sozinho entre as pessoas com maior renda. A solidão também está associada ao fato de ser mulher, viúva, divorciada ou solteira, com poucos amigos, ter deterioração da saúde física (como no caso de declínio na mobilidade), falta de recursos socioeconômicos (baixa escolaridade ou renda) e menor acesso a serviço de carro particular ou dependência de transporte público (Silva et al., 2014; Ong; Uchino; Wethington, 2016; Barbosa; Oliveira; Fernandes, 2019). De forma geral, família e amigos são as figuras principais de redes sociais dos idosos, além das redes secundárias (organizações políticas, religiosas e trabalho, por exemplo). Porém, o envelhecimento pode provocar mudança nas relações familiares e entre amigos no que se refere à estrutura da rede e ao papel desempenhado dentro dessa rede, de forma a favorecer 0 isolamento (Barbosa; Oliveira; Fernandes, 2019; Almeida; Maia, 2010).

Assim como nas entrevistas, a literatura apresenta que a solidão pode intervir de diversas maneiras no bem estar. Laços sociais fornecem suporte essencial em momentos de doença (auxiliando, por exemplo, em uma recuperação mais rápida ou procura mais precoce por atendimento), incentivam as pessoas a adotarem melhores hábitos de saúde e inclusive impactam no funcionamento do sistema imunológico, além de que a ausência desses laços pode implicar comprometimento cognitivo e autopercepção ruim da saúde, aumento de mortalidade e redução da prática de atividades saudáveis ou capacidade de sobreviver a um desastre natural (Myers; Palmarini, 2017; Ong; Uchino; Wethington, 2016). De fato, a disponibilidade da família pode ser considerada um fator de proteção para o envelhecimento, uma vez que a solidão, depressão e condições ruins de saúde estão relacionadas à ausência de parentescos (Barbosa; Oliveira; Fernandes, 2019). Dessarte, a ausência de envolvimento em redes sociais tem sido considerada igualmente danosa para a saúde quanto o tabagismo, hipertensão arterial, sedentarismo e obesidade. Por essas relações, sugere-se que o declínio da condição de saúde possa ser causado por doenças e hábitos de vida considerados inadequados, mas também por relações sociais precárias, quer seja em quantidade quanto em qualidade (Brito et al., 2018). 
Diante desse quadro, isolamento social ou solidão e dificuldades com a família (ou a ausência da mesma) configuram-se dentro dos principais desafios para a realização do cuidado do idoso na atenção primária, perpassando a questão da autonomia quando se encontra também limitações no horizonte das relações possíveis para o idoso, a família e a equipe.

\title{
5.3.3.1.4 Condição socioeconômica e comunidade
}

A baixa condição socioeconômica também foi apresentada como uma das dificuldades encontradas pela equipe. A limitação dos recursos pessoais é vista como uma fonte de insegurança ou medo (diante de uma possível incapacidade de arcar com custos necessários na velhice) e impedimento para prática de hábitos de vida mais saudáveis.

\begin{abstract}
Segurança da assistência, em sentido que aqui, infelizmente, se não tem a possibilidade econômica de ter algum convênio, de ter uma outra assistência além da nossa do sistema público, que, infelizmente tem muitos limites, isso cria uma grande insegurança, pensando no futuro. Então a pessoa que já tá caminhando vai ser, vai ficar idosa, fica muito mais insegura aqui. Porque se acontecer alguma coisa, se ficar com alguma deficiência, se tiver algum agravo mais importante, que fica a pessoa mais dependente, isso cria uma insegurança enorme, porque não tem a segurança da assistência. Nem médica, nem essa questão do cuidado, do cuidador. O acesso a uma estrutura, uma ILPI, uma estrutura que dê uma assistência. Ter a possibilidade econômica de pagar alguém que fique durante o dia. Isso aqui tem uma coisa que depende muito da possibilidade individual e muito menos dos financiamentos públicos (Andrea, MFC, ao conversar sobre algumas dificuldades que encontra no Brasil que são diferentes das vividas em seu país de origem).
\end{abstract}

A senhora come carne, come ovo? A gente acaba perguntando, e muitos falam que recebem salário mínimo, que às vezes têm que comprar remédio, muitas vezes o remédio não tem aqui.(Diego, técnico de enfermagem).

A equipe também apresenta situações em que a condição financeira do idoso é determinante para as relações de cuidado. Em alguns casos, o idoso é o principal provedor, de forma que as necessidades da família orientam a forma de administração dos seus recursos (sendo necessário ir contra o seu desejo). 


\section{Em outras situações, a condição de baixa renda das famílias interfere na possibilidade de prestar assistência ao idoso.}

A filha ia cuidar e nem a mãe queria morar com a filha porque a casa era bem organizada e a filha não trabalha, mas também dependia da mãe no sentido financeiro porque a filha deixou de trabalhar para fazer o cuidado da mãe, automaticamente a mãe passou a fazer o sustento da filha por conta disso. (Diego, técnico de enfermagem)

Laura: Hoje mesmo eu tenho que ir na casa dela levar um papel porque eu não consegui fazer essa troca para ela ser encaminhada para o cárdio. Mas não é porque eu não consegui, é porque ela precisa passar em consulta aqui. Faz muito tempo, tem que estar tudo registrado, tem que vir. Daí eu vou conversar com o filho para ver se ele traz ela.

Entrevistadora: E quando você fala com o filho dela, ela acha ruim?

Laura: Não, ela não acha. Mas depois, quando ele vai embora ela fala "ele não vai não, não adianta você falar com ele". Mas não na frente dele. Depois, quando ele vai embora. Depois, no outro dia, eu falo "por que você não foi?", "ah, meu filho estava catando papelão na rua, você acha que ele vai me levar? Ele tem que buscar uma carga não sei onde, e tem que comprar o gás", essas coisas que ela fala.

(Laura, ACS).

Ela me trouxe uma, duas vezes, na terceira vez "você não está entendendo, Martina, eu não quero morar com ela, eu quero que me respeitem, eu quero muito morar num asilo em que eu possa andar, conversar com as pessoas, ter meu quarto, pronto, é aquilo, acabou" e nesse dia eu falei "não é possível, terceira vez que ela me traz que quer morar sozinha e ela está com a filha", e aí eu chamei a filha, chamei a assistente social, saí da sala "Débora, me ajuda, tem uma situação aqui que não estou sabendo lidar porque a paciente está me trazendo a vontade dela e tem uma família e que eu acredito que essa filha seja sustentada com o salário da mãe, por isso que estão morando as duas, e tem outra, é a filha que quer cuidar da mãe, tem toda uma situação, mas ela é muito lúcida, o que eu faço com uma paciente que diz que quer morar sozinha, e não é a primeira vez, me ajuda a intermediar isso". Aí veio a aprimoranda, colheu toda a história e era isso mesmo, a idosa queria muito morar no asilo, ela tinha uma aposentadoria que dava para pagar e ela queria visitar esse asilo para escolher, mas, ao mesmo tempo, ela morava com uma filha que dependia do salário dela para se sustentar e que toda a família achava que era bom que ela cuidasse dela porque, enfim, era sozinha. (Martina, enfermeira). 
Dentre os entrevistados idosos, João foi o que mais referiu limitações no cotidiano pela condição financeira.

João: Uma coisa que eu gostaria de fazer, era colocar meus dentes, fazer um implante, né? Mas não tenho possibilidade de fazer (...)

Entrevistadora: E o senhor acha que isso interfere com as questões da saúde, também, ter ou não o cacife ${ }^{29}$ ?

João: Ah, eu acho que sim. Porque com dinheiro você compra alguns médicos, né? Boas enfermeiras, boas farmácias. Remédios. Com dinheiro, você paga e o profissional vem e faz. (...) Eu gostaria de ter dinheiro e pagar um otorrino e comprar meu aparelho, como eu sempre fiz. Então esse último aparelho eu ganhei da Reouvir.

Esposa: Olha pode-se pagar em prestação, agora.

João: Tá. Eu sei que eu posso pagar em prestação. Da Reouvir. Eu ganhei da Reouvir. Mas é um preço alto. Você se sente humilhado, sabe? Ficar lá naquela fila, cabeça baixa. Quando eu ia na empresa que vendia os aparelhos, era tratado com cafezinho, sentava, era bem... Todo mundo com sorriso. Vamos fazer isso, fazer aquilo. Você vai agora no hospital, lá não e nem hospital, é uma ONG, não sei, a Reouvir. Então, você vê a má vontade do pessoal pra te atender, pra... E você é obrigado a engolir. Essas coisas eu não gosto. Eu não gosto dessas coisas. (João, 81 anos).

Como no relato de João, o reconhecimento como cidadão e como indivíduo autônomo são esperados pelos idosos. Porém, baixos rendimentos e a presença de problemas de saúde desafiam a independência, gerando piora na qualidade de vida, em especial dos que conferem grande valor ao individualismo e autodeterminação.(Barbosa; Oliveira; Fernandes, 2019).

Além das situações inerentes ao próprio idoso e ao seu núcleo familiar, a vulnerabilidade socioeconômica se apresenta na vida em sociedade especialmente, nas narrativas, na violência intra-familiar e na comunidade.

Carolina: Mas idoso, por exemplo, a gente tinha uma que morava com uma sobrinha adotiva, vai, digamos assim. Aí maltratava. Bastante violência, né? A gente tá pegando muito caso de violência, assim.

Entrevistadora: Que tipo de violência?

Carolina: Física, verbal, psicológica. E é duro se meter nisso, assim. A gente tenta contornar de todas as formas. Aí várias vezes aciona Ministério Público, não faz nada. A maioria das vezes não resolve. (Carolina, enfermeira)

\footnotetext{
${ }^{29}$ Utilizado termo como referido pelo entrevistado como sinônimo de melhor condição financeira ou dinheiro.
} 
Entrevistadora: Dentro dos seus atendimentos quais as limitações funcionais que você mais nota aqui na atenção primária?

Daniela: Isso já é uma coisa não só da atenção primária, mas a gente já nota um declínio funcional de atividades instrumentais relacionadas ao nosso ambiente de violência. Muitos idosos param cedo de dirigir, de cuidar da própria finança no banco por medo de violência nos deslocamentos principalmente. Às vezes você já vê muito claramente que não tem relação com a saúde, é uma questão mais social. $E$ aí o que a gente vê de pacientes que vão tendo um declínio físico muito rápido, vão fragilizando, é que eles vão perdendo muito a capacidade de deslocamento dentro de casa, de deambulação que necessita de apoio, então é muito comum que a gente veja dificuldades que necessitam de bengala, de órtese. (Daniela, geriatra)

A gente sempre fala da caminhada. Uma coisa que eles gostam e a gente ficou sem..., na verdade eu acho que foi a questão, não sei se foi isso, mas acho que foi a questão do lugar para fazer a caminhada, porque quando acabou eu falei "ah, gente, faz a caminhada no quarteirão", mas aí eles "mas tem os moradores de rua" e tinha um lugar que chamava Areião que era usado para fazer as caminhadas, mas o pessoal invadiu lá e ficou muito perigoso e agora que estão arrumando de novo, e aí foi para a rua Tabajara, não sei o que foi lá, e aí acabou a caminhada. (Carla, ACS)

Olívia: Eles até queriam sair, mas o medo de saírem... alguns falam "ah, eu não consigo mais sair dois, três quarteirões, eu tenho medo porque tem tanto assalto aqui na rua" e sabe, todas essas coisas assim. E não tem um lugar de lazer para eles, é longe daqui (...)

Entrevistadora: E tem muito problema de assalto mesmo? Você comentou que eles ficam com medo.

Olívia: Por aqui sim. Não sei se foi nessa semana ou na retrasada que onde eu moro, um senhor mora sozinho e disse que entrou um ladrão e levou as coisas dele. Que ele estava com a janela aberta e ele estaria sentado perto da janela e ameaçou com uma faca para passar a chave, entrar e pegar tudo. Dá medo, esse lugar é muito perigoso. Durante o dia estão roubando celular no ponto de ônibus, sabe, dá muito medo de andar. (Olívia, ACS)

Rafael: Os idosos é o que mais foram receosos. Acho que por conta dos filhos falarem "Olha, não abre a porta pra ninguém. Se não conhecer, não abre."

Entrevistadora: Você acha que atrapalhou eles se abrirem, também, diferente por você ser homem?

Rafael: Sim. Sim. Principalmente as idosas, do sexo feminino, né? Idosos do sexo masculino, eu tenho poucos. Não são uma grande maioria. A maioria é sexo feminino, né? E elas são as que tiveram mais receio e até mesmo, às vezes medo de me receber, né? Até porque normalmente as pacientes que eu tenho, elas ficam sozinhas o período da manhã e da tarde, que os filhos trabalham, então só chega a noite. E aí foi muito difícil. (Rafael, ACS, ao contar sobre as dificuldades que 
desafiou no começo do seu trabalho na saúde por ser do sexo masculino, com maiores inseguranças dos pacientes por medo de golpes)

Vai subir a pé. Problema de assalto. Foram assaltadas. Problema de acidente. Tá. Então libera o ônibus. A gente libera, mas resolveu pra gente e pros pacientes? (Martha, ACS)

No cenário específico dos idosos que residem na favela, são condições que impactam a realização do cuidado as inseguranças com a moradia (em termos de posse) e os limites impostos por algumas lideranças locais.

Então eu sabia do meu limite com a comunidade, com os traficantes, que tinha que respeitar, a gente respeita muito a palavra deles até porque a gente precisa se resguardar... (...) Chega um momento que eles falam "Martina, não pode ultrapassar isso, fazer aquilo", tudo bem, a gente não faz, a gente respeita, até porque a gente precisa se preservar e preservar o trabalho. Se quebra o vínculo, não é só o vínculo com a Martina, é com a equipe toda e com posto, a gente tem que ter muito cuidado com isso. (Martina, enfermeira).

Joaquim: Não, a única coisa que eu queria era quando morresse, porque eu tenho fé de morrer dentro dessa casa, eu só saio daqui dentro do caixão, do contrário não saio não. Já lidaram para me tirar daqui, eu não saio nada! Pode tentar me tirar daqui, eu quero onde é que vocês vão me por.

Entrevistadora: Já tentaram te tirar daqui? Quem que quis?

Joaquim: Já, um vagabundo que tem aqui queria tomar a casa na marra, "vocês tomam nada". Antes de vocês chegarem na porta, vocês morrem.

Entrevistadora: É gente do bairro que quis pegar sua casa?

Joaquim: É malando que tem aí dentro. Vagabundo que tem aí dentro. Falei "vai, tenta, tenta entrar no quintal, vai lá arrombar a porta, você nem sabe de onde é que saiu a bala que pegou em você". (Joaquim, 89 anos)

Lá no Parque do Gato a gente tinha inclusive alguns idosos que sofriam pressão da comunidade, se eles percebiam que o idoso não tinha família, não tinha suporte nenhum, eles ficavam pressionando para liberar o apartamento e lá é um apartamento que teoricamente é social, foi distribuído, mas a gente sabe que não é assim, infelizmente. $\mathrm{E}$ aí a gente lá lidava com isso. (Fernando, MFC - ao relatar sua experiência em outro território próximo ao que atua hoje) 
Barbosa, Oliveira e Fernandes (2019) apontam que de fato uma vizinhança pobre e com privações está associada a pior saúde cardiovascular, aumento da incidência de doenças infecciosas, da prevalência de depressão, de limitação funcional e pior auto avaliação de saúde. Além disso, pode interferir com o acesso a equipamentos e serviços de saúde, reduzindo a adesão a práticas de saúde. Em estudo que utiliza base de dados do ELSI (FERREIRA et al., 2018), a preocupação com percepção de vizinhança muito insegura, apesar de frequente ( $37 \%$ dos idosos entrevistados) não apresentou associação significativa como limitação para melhor participação social. Contudo, os autores assinalam que a literatura tem mostrado que mais comumente a percepção de uma vizinhança violenta interfere na volição dos indivíduos em sair de casa, incorre em prejuízo na saúde física, emocional, na participação social, na autonomia, na independência e na prática de atividade física, o que está de acordo com o observado pelos depoentes.

Dentre as questões sociais, a literatura aponta ainda que a raça constituise num importante marcador de vulnerabilidade social entre os idosos (Barbosa; Oliveira; Fernandes, 2019). Negros e pardos possuem menor renda, escolaridade, maior desemprego, piores relações de emprego e de condições de moradia, além de maior dificuldade a acesso a bens e serviços quando comparados a brancos. Nas entrevistas, contudo, a questão racial não foi apontada como dificuldade para realização das práticas assistenciais aos idosos já adscritos. A agente comunitária que se declarou negra refere, porém, que já apresentou problemas para visitar uma família por ser negra.

\subsubsection{Dimensão Programática}

Neste plano, em que a atuação dos serviços aparece como elemento de acentuação ou mitigação das vulnerabilidades anteriores, as equipes e os idosos referiram dificuldades relacionadas ao cuidado que podem ser aglutinadas em vivências quanto a acesso, organização do trabalho no centro de saúde, rede e intersetorialidade. 


\subsection{Acesso e acessibilidade}

O acesso, ou primeiro contato, é um atributo essencial da Atenção Primária à Saúde e se refere ao fato de esta ser a porta de entrada preferencial da população ao serviço de saúde. Quanto a este primeiro contato, Starfield (2002) apresenta o acesso como a possibilidade de uso dos serviços em tempo oportuno e de forma a atender às necessidades da população e a acessibilidade como os fatores que favorecem ou obstaculizam a chegada das pessoas aos serviços. Em outras palavras, a acessibilidade diz respeito a questões sócioorganizacionais (por exemplo, a necessidade de ir agendar consulta em um dia e horário determinado do mês, pagar por um atendimento, não dispor do serviço ou tipo de atendimento que se necessita) e geográficas (como tempo, distância para se chegar ao serviço de saúde, obstáculos físicos); já o acesso tem relação com a forma como se experimenta essas características do serviço de saúde. Atualmente observa-se "uma tendência de ampliação da abrangência do conceito de acesso, deixando de enfocar somente a questão da entrada nos serviços para incorporar também os resultados dos cuidados recebidos, dando importância à discussão da justiça social e da equidade" (Campos et al., 2014, p. 254), também tem-se considerado aspectos qualitativos relacionados ao acolhimento e ao seguimento no usuário no sistema. $O$ acesso é um conceito complexo e envolve fatores multidimensionais em que se pese ainda aspectos sociais e políticos. Assis e Jesus (2012) apresentam a proposta de cinco dimensões para análise do acesso/acessibilidade: geográfica, política, econômico-social, técnica, organizacional e simbólica ${ }^{30}$. Tal classificação não será utilizada por ir além do escopo deste trabalho, embora suas proposições transpassem o exposto nos relatos.

\footnotetext{
${ }^{30}$ A proposição de Assis e Jesus foi baseada em Giovanella e Fleury. Para mais informações sobre o tema: Giovanella L, Fleury S. Universalidade da Atenção à Saúde: acesso como categoria de análise. In: Eibenschutz C, organizadora. Política de Saúde: o público e o privado. Rio de Janeiro: Fiocruz; 1995. p. 177-198 e Jesus Washington Luiz Abreu de, Assis Marluce Maria Araújo. Revisão sistemática sobre o conceito de acesso nos serviços de saúde: contribuições do planejamento. Ciênc. saúde coletiva [Internet]. 2010 Jan; 15(1): 161-170. Disponível em: http://www.scielo.br/scielo.php?script=sci_arttext\&pid=S1413$81232010000100022 \&$ Ing=en. https://doi.org/10.1590/S1413-81232010000100022.
} 
Nas narrativas no que tange a acessibilidade e os idosos, foram apresentados como pontos limitantes do cuidado a distância entre algumas regiões do território e o centro de saúde, a presença de um viaduto sem adequado espaço para o pedestre caminhar e, para outra equipe, inadequação do tempo do semáforo para a completa travessia da rua. Considerando as mudanças físicas habituais nesse ciclo de vida, as questões de acessibilidade limitam uma intervenção mais positiva do aspecto programático sobre a vulnerabilidade do idoso na região.

\footnotetext{
Mas tenho pacientes que não vêm até aqui, porque tem medo de atravessar a avenida. Porque não se sente seguro. Porque não se sente protegido. Porque para atravessar a rua do farol que fica aberto 30 segundos, a pessoa tem medo de não dar tempo. (Andrea, MFC).
}

Eles ampliam muito o território, por isso que... Quem faz isso, trabalha em mesa. Eles não sabem a dificuldade que tem de um paciente se locomover de lá pra cá. Foi o caso quando eles puseram a gente lá pra cima e o pessoal que tinha bebê, que vinha passar na pediatria, não conseguia passar no viaduto. Tinha que dar a volta lá pelo metrô. Quer dizer, ninguém pensou que tinha uma ponte dividindo a nossa área (Martha, ACS)

A acessibilidade também interfere no uso de outros pontos da rede e de fato não deve ser uma característica apenas da APS, já que todos os pontos da rede devem ser acessíveis (Starfield, 2002). Em especial em cidades grandes, como a capital paulista, associado a limitações de mobilidade para o idoso (não só determinadas por capacidade intrínseca de locomoção, mas por fatores como analfabetismo, acesso a transporte pessoal ou público, companhia ou falta de adaptação dos espaços públicos para os idosos), a procura por serviços da rede pode ser prejudicada pela distância.

Às vezes quando é idoso eu tenho que interferir porque ele fala para mim. "Dé, sou deficiente visual, não tenho ninguém, eu deixei o papel com a M., mas esqueci de dizer, pelo amor de Deus, para ela não marcar na zona leste", às vezes eu interfiro, quando o idoso traz algumas questões eu interfiro "M., coloca uma observação tem que ver vaga aqui, do lado". Mas isso é uma coisa que a gente já percebe, quando é idoso, pessoa com deficiência, tentar o entorno, não deixar a pessoa ir para muito longe porque dificulta o transporte, quem vai acompanhar (Débora, assistente social). 
Ferreira et al. (2018) em amplo estudo que faz uso da base de dados do ELSI apresenta que efetivamente a mobilidade urbana (envolve travessia de ruas e cruzamentos, deslocamento em calçadas com segurança, embarque e desembarque de meios de transporte) é essencial para a facilitar ou prejudicar a participação social em especial dos indivíduos mais velhos, que são particularmente sensíveis a estas características do seu entorno. Essas características urbanas interagem com as particularidades do indivíduo e podem favorecer a exclusão social. A preocupação com a dificuldade para travessia de rua é frequente em inquéritos nacionais e internacionais, o que se reflete na morbimortalidade por causas externas nos idosos: entre setembro de 2016 e 2017, 51\% das mortes de pedestres no trânsito nas cidades brasileiras envolveram pessoas com mais de 50 anos. De igual modo, segundo o estudo, a preocupação com problemas para embarque em ônibus metrô ou trem restringe a participação social dos idosos, independentemente do sexo.

Acesso e acessibilidade também ficam prejudicados em outros momentos por impossibilidade de acompanhamento mais frequente pela quantidade de vidas abrangidas em uma área, tornando ainda limitada a oferta de visitas domiciliares (especialmente para os profissionais que compõem a rede de apoio do serviço, como fisioterapia) e de consultas, acarretando sobrecarga das equipes e limitação do tempo.

No caso específico das visitas domiciliares, a limitação para sua realização impacta particularmente a população idosa que, em geral, é a que mais demanda esse tipo de assistência.

Às vezes, falta de acesso ao serviço por conta de não ter ninguém pra trazer eles, que moram sozinhos. Porque a gente vai na casa, né? A Andrea vai, eu vou, os agentes vão. Só que geriatra não vai, né? E físio vai bem pouco, quase não vai também. Então, talvez, seja uma das coisas mais principais, assim, o acesso. (Carolina, enfermeira)

A grande dificuldade que a gente... Que pelo menos eu sinto do cuidado da pessoa idosa menos independente é a dificuldade de ter um acompanhamento mais frequente. Porque não temos a possibilidade física e material. São muitos pacientes, são muitas pessoas e, principalmente, a equipe técnica. Então a equipe médica, 
enfermeira... O agente de saúde até, muitas vezes, acaba indo mais de uma vez por mês, que seria obrigação. Mas o agente de saúde tem algumas limitações do que pode e que sabe fazer. (Andrea, MFC).

Com o volume de atendimento, os retornos estão mais espaçados (agenda em geral com espera de 3 a 4 meses nas equipes, exceto na que adotou acesso avançado ${ }^{31}$ )

O retorno da consulta do idoso eu acho que está bem abaixo do que deveria ser. Não pela qualidade médica, mas pela quantidade de vagas que o médico tem para poder fazer o seu atendimento. Então eu acho que assim, hoje o idoso passa, para voltar para o retorno acaba demorando de 3 a 4 meses. (Diego, técnico de enfermagem).

Eu acho que o difícil é o complementar do meu trabalho. De eu chegar na casa do paciente e falar assim: "Olha, vai lá no posto que o senhor vai ser atendido. O senhor vai passar em consulta." "Ah, mas é pra três meses. Ah, então nem vou." Eles falam. "Ah, tem que esperar dois meses? Então não vou." Eu falo: "Não. Mas é difícil, é demorado. Mas, assim, já deixa marcado". (Rafael, ACS).

O acesso e a realização de um cuidado integral também foram impactados pelo fator "falta de tempo". Ao se referir a questões pertinentes ao tempo, a equipe aponta a falta de tempo para pensar em outros caminhos (pela relação entre as cobranças e as metas quantitativas impostas e o desejo de refletir mais em medidas individuais ou coletivas), tempo curto para realização de uma consulta de qualidade ${ }^{32}$ e sensação de "trabalho inacabado" pela sobreposição de casos complexos (começam a abordar um caso complexo,

\footnotetext{
${ }^{31}$ Acesso avançado, acesso aberto, ou consultas do dia é um método de organização do agendamento que objetiva que os usuários que busquem atendimento o receba com sua equipe de referência no momento mais oportuno, preferencialmente no mesmo dia. $\mathrm{O}$ acesso avançado tem como regra de ouro "faça hoje o trabalho de hoje". Em geral, não há divisão da agenda em períodos reservados a grupos específicos (como consultas de pré-natal, puericultura, para hipertensos, etc). A agenda permanece aberta e seus horários são ocupados diariamente, conforme a demanda, com um tempo limite de agendamento variável entre os diferentes serviços. Em muitos, como na equipe em questão, usa-se o limite de 48 horas para efetivação da consulta. $\mathrm{O}$ acesso avançado também prevê a reserva de alguns tipos de agendamentos com duração de consulta mais extensa e a agenda pode ser dividida entre agenda aberta (para consultas do dia ou com agendamento breve) e a agenda "protegida" (para esses atendimentos mais extensos, como pré-natal).

${ }^{32}$ Conforme queixas dos profissionais registradas em caderno de campo.
} 
depois surge outro com uma demanda mais urgente e nesse fluxo as situações se sobrepõem).

\begin{abstract}
Mas a partir do momento que a gente começa a ter muitos casos complexos como fica a rotina das equipes? A gente sabe que o evento envelhecimento está aumentando cada vez mais e eu não sei se as equipes estão preparadas para ver isso, para ver autonomia e para entender também que a gente vai fazer cuidado paliativo no domicílio, eu acho que ainda não. (...)

Eu acho que, como a gente diz, o problema é o mesmo, mas há modos e modos de enfrentá-lo. É complicado, quando a gente diz, um atendimento de qualidade. Quando você para pra pensar em qualidade você tem que ter muito mais tempo, mais horas com aquela família e hoje a saúde, principalmente nesses últimos dois anos, está vivendo um momento muito mais quantitativo do que qualitativo, a gente sabe disso. Quando você para pra falar "olha, eu tenho pouco tempo com aquela família então eu vou fazer o que eu sei que vai dar certo", não é que a gente está agindo errado, mas você parar para pensar em outras formas e tentar aplicar vai demorar muito mais tempo, você vai ficar muito mais vezes nesse caso, por outro lado, vão estar te cobrando meta, os outros idosos que você não foi visitar. (Débora, assistente social)
\end{abstract}

Eu acho que na saúde fica só naquele negócio... tem muitos casos que a gente fala e muitos não são resolvidos, que nem essa paciente, a Dona I., faz dois anos e não tem nada, vai fazer o que, não tem para onde recorrer, muita coisa deixa a desejar. E no serviço da gente a gente fica um pouco triste porque sabe que não vai resolver. Fica lá só levando informação, leva papel, traz papel, mas não tem a devolutiva para nós, eu acho que muita coisa deixa a desejar. Mas não o lugar que eu trabalho, são as coisas que não se resolvem. (Laura, ACS)

É. Porque eles tão mais preocupados com meta, né? Vamos supor, se tivesse uma TO [terapeuta ocupacional] aqui, ou se eles... Mesmo o físio tivesse mais tempo de fazer visita domiciliar, ia ajudar muito, né? Mas não. Então é tudo muito restrito. Então você tem que ir pelos seus caminhos. Cê tem que ir descobrindo seus caminhos. (Martha, ACS).

Por outro lado, no ambulatório da geriatria, em que se tem um atendimento com maior duração e uma abordagem mais acadêmica, há a queixa por parte de alguns agentes comunitários de que os idosos não gostam da abordagem pela demora durante o atendimento (não para o agendamento), mais especificamente, pelo tempo aguardado para o retorno das orientações após a discussão; ao passo que outros trazem apenas pontos positivos do ambulatório 
de geriatria. Durante acompanhamento do ambulatório, em trabalho de campo, num geral os usuários elogiaram por ser uma consulta mais longa (cerca de 1 hora). Após anamnese e exame físico, aguardam o retorno do aluno com ou sem a preceptora com as orientações, prescrições, etc. Esse retorno que demora mais (sem um tempo médio determinado, dependendo também das discussões que acontecem dos outros casos). É sobre esse tempo de espera que relataram algumas queixas.

Entrevistadora: E você comentou, também, que aqui tem o serviço de geriatria.

Martha: Tem.

Entrevistadora: E que aí você consegue encaminhar alguns casos pra lá?

Martha: Sim. Eu tenho uma ressalva, também, quanto a isso. Eu acho uma judiação você trazer um idoso cadeirante, vamos supor, pra vir aí fazer na geriatria. Passa com residente. Às vezes, o idoso chega aqui a uma hora e sai daqui as cinco. Eu acho uma judiação fazer isso com o idoso.

Entrevistadora: Eles já falaram pra você que gostaram, que não gostaram?

Martha: Não. Não gostam. Não gostam justamente por causa disso.

Ela ficou a tarde inteira na cadeira de roda. Ela chegou aqui uma hora, saiu as cinco. É muito tempo. O idoso acamado ou que não seja, domiciliado, ficar fora de casa, assim. Sem comer, né? (Martha, ACS)

Precisavam de um atendimento melhor porque a agenda da Doutora Andrea é muito cheia às vezes então não tem como dar aquela atenção para o idoso numa consulta, no que ele precisa mesmo. Então, aqui, para a gente, o que precisava e chegou para a gente foi a geriatria, que eu achei muito bom, meus pacientes têm gostado bastante que eles podem falar, se queixar. (Carla, ACS).

Para os idosos houve queixa quanto ao acesso a alguns serviços no que se refere à demora na oferta.

A única coisa que eu tenho aborrecimento é que eu não posso andar mais, a perna ficou torta, ela não estica mais do que isso, eu estou com o papel para fazer fisioterapia na perna, mas não tenho fé de que ela vai esticar mais não. Ela não estica mais, só até aqui. Se tentar esticar um pouco mais eu não aguento a dor. Tenho marcado, mas não tem vaga. (Joaquim, 89 anos)

Se tivesse colocado ela no meu carro, talvez não tivesse dado um infarto tão forte. Mas eu esperei o SAMU [Serviço de Atendimento 
Móvel de Urgência]. O SAMU demorou três horas. Então, você não pode contar, né? (João, 81 anos).

Excesso de demanda, numerosa população vinculada as equipes da ESF (muitas vezes agravada pela grande centralização no atendimento médico), demora para agendamentos são problemas apontados, em geral, por usuários e profissionais da saúde, não apenas vinculadas às questões relacionadas à saúde do idoso (Campos et al., 2014; Tesser; Norman; Vidal, 2018; Assis; Jesus, 2012).

\subsection{Organização do trabalho}

Segundo as narrativas, a oferta de espaços de trocas de usuários entre si e destes com os profissionais de saúde diminuiu gradativamente ao longo dos anos nesta unidade de saúde. Fato apresentado pelos entrevistados como uma das dificuldades no cuidado do idoso, em que se pese o seu valor para socialização, construção de vínculo e melhoria da qualidade de vida. Ações como grupos de culinária saudável, caminhadas, Lian Gong, passeios (facilitados pela disponibilidade de transporte gratuito), bingos, chás e festa junina tinham grande aceitação e participação da comunidade. Para muitos profissionais a redução nessas atividades em prol da realização de outras demandas desconsideram as necessidades de saúde que enxergam como prioritárias na saúde dos idosos.

Martha: Se a pessoa é um idoso que vive lá sentado numa cadeira, sozinha, vendo televisão, que expectativa de vida ele tem? Se você não estimular ele a fazer uma coisa? O PAI tava fazendo com parceria com a gente, uma vez por mês, um bingo... Bingo, só pra juntar. Eles vinham. Eles pegavam Uber e vinham. A gente tinha 40, 50 idoso de toda área, né? Quer dizer, não é um incentivo pra eles? Então o que falta é isso, entendeu? (...)

Terapia comunitária que eles até hoje pedem pra gente voltar. Eu acho que foi uma coisa boa. Inclusive a terapia a gente fez na favela. Gerou, assim, bastante resultado também. Uma coisa boa, também, que eu sinto muito que tenha acabado, é o grupo de caminhada e o grupo de Liang Gong...E as viagens. Porque antigamente a gente tinha ônibus de graça. Então a gente levava os idosos pra fazer um... No baile dos idosos, lá na... Ai, meu Deus, me fugiu o nome. No Horto Florestal. A gente fazia, levava os idosos pra fazer um piquenique, vai, na Água 
Branca. Depois cortou esse ônibus de gratuidade. Aí a gente começou a fazer com ônibus alugado. Só que a gente... Ficou muito caro. Hoje em dia pra você fazer uma visita, você tem que dispensar 60,70 reais pra você fazer uma viagem com os idosos. Que a maioria ganha um salário mínimo. São poucos os que ganham um pouco mais.

Entrevistadora: E o que você notava dessas ações, assim, de impacto pra eles?

Martha: Ah, eles adoravam. Porque era a socialização deles. Então eles já ficavam esperando. Pelo menos uma vez por mês eles iam ao baile, eles iam fazer um piquenique. Então era um jeito de tirar eles de casa. (Martha, ACS)

O que eu te falei, acho que as atividades que poderiam ter para os idosos, falo daqui que o meu primeiro contato com o SUS como trabalhadora é aqui, caminhada, algumas coisas que eles pudessem... Ano passado estava tendo aula de nutrição que o professor que estava aqui, que era o Doutor A., ele trazia os idosos aqui e ele ensinava receitas de coisas bem naturais para os idosos, então eles estavam bem participativos, eles vinham até o posto, eu acho legal essas atividades para eles. (Carla, ACS)

Berenice: Até teve um corte das atividades que a gente fazia com os idosos, não tem mais, então eu fiquei muito triste, fiquei até com depressão.

Entrevistadora: $O$ quê que cortou?

Berenice: Cortou a festa junina, os nossos bingos, nosso chá, não tem mais nada, nosso passeio que é a qualidade de vida para eles.

Entrevistadora: Mas você sabe o motivo?

Berenice: Ah, não sei, ela não dá, ela fala que não pode fazer, a gente não fez mais nada (...)

Aí a doutora $\mathrm{H}$. falou "vocês têm que fazer grupo", que grupo que a gente vai fazer? Os grupos que a gente faz, papelada, essas coisas, eles [os idosos] não querem. Palestra, eles não querem escutar isso, eles falam "já escutei tanto, a gente quer se divertir com vocês, quer ter uma qualidade de vida melhor". Os passeios, toda vez que a gente foi, eles cobram da gente. Eu fiquei triste de ter acabado, era uma coisa que deu certo. (Berenice, ACS).

E perguntar mesmo essa parte, né? O que eles tão fazendo pra se divertir... E a gente tenta, agora tá menos aqui, mas a gente fazia muito, a gente tinha muitos locais de apoio, né? Igreja, tinha baile aqui, essa parte mais de promoção mesmo de festa, de diversão pra eles. Coisa que eles não têm muito aqui na região, né? (Carolina, enfermeira).

A percepção de que há um desencontro entre o que identificam como ações sensíveis às necessidades de cuidado dos idosos e as ações 
demandadas pela gestão (como de vigilância, entrega de documentos, de agendamento de exames, troca de data de consulta, etc) é referida não apenas no que é pertinente à falta das atividades de promoção à saúde.

\begin{abstract}
Martha: Eu tô falando assim, o qual o papel do agente de saúde? Não é você ir lá, você dar uma assistência, você dar seu ombro, você sentir o paciente, você dar toda a atenção, você mimar muitas vezes, né? Porque, às vezes, a pessoa tá sozinha, tá precisando daquele carinho extra. Hoje em dia, não me considero uma boa agente de saúde. Eu não me considero.
\end{abstract}

Entrevistadora: Por quê?

Martha: Porque eu não tenho mais tempo de fazer isso. Uma, o número de famílias é muito grande. A maioria é tudo idoso. Moram sozinhos. Aí você tem que... Eles te imputam um monte de tarefas que eu não sei se é da nossa alçada ou não. Mas mandou, você tem que fazer. Então você passa mais tempo entregando papelada do que você dando assistência. $E$ antes, também, não tinha esse negócio de você cumprir meta. Você cumpria, assim, numa boa. Hoje em dia, você se sente forçada a cumprir meta. Então, o paciente que, às vezes, eu podia demorar meia hora, hoje eu não posso gastar cinco, dez minutos com ele. E eu sinto falta disso, entendeu? Porque eu acho que esse tempo que eu passo com eles, não dá tempo de eu sentir. Tá certo que depois, nessa área eu já estou há sete anos, sete pra oito, só deles abrirem a porta, você sabe se ele tá bem, se ele não tá. Se ele tá triste, se ele tá alegre. Você só de ver o paciente, cê já vê. E, às vezes, você tem que largar os outros, pra dar mais atenção pra esse. $E$ isso me incomoda.

Entrevistadora: Porque sente que não dá mais.

Martha: É. Eu não tô dando a atenção que eu deveria ter dado. Eu falei pra A.: "Faz um check list." De tuberculose, de rato, de hansen, de mosquito, de plantas, vê os vasinhos". Então, às vezes, você vai, você fica até sendo chata, né? Porque todo mês você vai ter que perguntar esse check list. (Martha, ACS).

Em relação à estrutura foram destacadas a burocracia dos processos e a falta de informatização. Esta impactou no cuidado pelo tempo gasto para preenchimento de papeis e pela diminuição da conectividade interna à rede (ao que se pondere as possibilidades mais factíveis de referência e contra-referência em um sistema informatizado unificado).

$\mathrm{Na}$ rotina de atendimentos, há a checagem no dia anterior de quais usuários estão agendados. Depois o administrativo imprime as agendas e separa os prontuários (nem sempre todos são encontrados, por questões de mudanças de registros, etc). Os prontuários são destinados às diferentes salas 
de atendimento. Na pré-consulta, os técnicos de enfermagem dividem os prontuários entre as diferentes agendas (por exemplo, na sala destinada preferencialmente para os atendimentos da Estratégia há 3 consultórios, uma pequena recepção - onde fica esse profissional que faz a pré e a pós consulta) e algumas cadeiras na sala de espera. Durante essa separação das agendas, os técnicos checam se estão presentes todos os prontuários necessários, caso ausentes, avisam para o administrativo ou eventualmente solicitam ajuda de algum ACS caso presente. Na sequência colocam as folhas de atendimento (há diferentes tipos de folhas conforme o tipo de atendimento a ser realizado ou a preferência do profissional). Durante a consulta, se for necessário o preenchimento de guias de Laudo de Medicamentos Especiais, renovação das receitas, atestados, etc, tudo é feito à mão. Na pós consulta, os pacientes retornam com as diferentes solicitações para os técnicos que preenchem manualmente etiquetas de identificação com informações como nome completo, data de nascimento, endereço, cartão nacional de saúde e anexam a cada pedido que precise seguir caminhos diferentes (ex: solicitação de mamografia, exames de sangue e um encaminhamento para oftalmologia - cada uma dessas guias, precisa receber uma etiqueta em separado com todas essas informações).

E aí essa é outra parte crítica que é o alto custo, é fazer 200 mil papéis, muito burocracia para conseguir os anti-colinesterásicos na rede, é um sofrimento para o paciente e é um sofrimento para nós porque às vezes você gasta 20 minutos para preencher esses papéis e tem que ficar fazendo isso a cada três meses, é dramático, às vezes a gente gasta um tempo de consulta que a gente poderia estar abordando outras questões, estar orientando família com cuidado e a gente gasta fazendo papel do alto custo (...) Isso é muito difícil, é o que eu mais sofro aqui é papel, não ter esse prontuário eletrônico e conduzir paciente com demência aqui, pelo menos essa parte inicial. (...)

Acho que a gente está atrasado uns 50 anos e não vai conseguir caminhar de forma positiva em termos de gestão e saúde se não informatizar as UBS, não tem como, não é possível 2019 ainda não ter prontuário eletrônico, é chocante isso, você gasta maior tempo em papéis e papéis, e a gente não tem dados fidedignos de incidência, de prevalência de doença, o que a gente está melhorando na população, se a gente está realmente melhorando a saúde da nossa população, de assistência, de forma geral, é essencial informatizar, que a gente vai conseguir fazer uma conexão melhor da rede, eu acho que os dispositivos todos estão aí, mas eles são mal conectados, de forma 
geral. E essa falta de comunicação dos serviços que dificulta, por exemplo, chega o paciente lá no $\mathrm{HC}$, serviço terciário, eles não têm conexão nenhuma com a rede, você não consegue devolver o paciente do HC para a atenção primária, por exemplo, e aí o paciente está acompanhando sem indicação no serviço terciário. Acho que mais isso mesmo e capacitar as equipes. (Daniela, geriatra)

Uma coisa é você trabalhar. Falar assim: "Vou fazer visita." Você fazer visita, assim. Outra coisa é você mexer com papelada. E outra, é muita papelada que você tem que preencher. $E$ se você não preenche todo dia, chega no fim do mês, você tá ferrado. (Martha, ACS)

Fabiana: Ou questões do tipo... A própria operacionalização do nosso trabalho. Então, por exemplo, essa lista... Essa avaliação global, a gente tá fazendo em toda nossa população. Então você precisa... Pra eu fazer esse controle desses idosos que tão sendo avaliados e dar segmento pra esses idosos que precisam, os idosos mais frágeis, a gente precisa ter um programa que ajude isso. Então, por exemplo, ter internet, acesso à internet muito mais fácil, ter computadores melhores, ter computador nas salas pra gente poder mexer nas nossas coisas, né? Nos nossos arquivos pra discutir em reunião de equipe. Então, essas coisas acho que... A questão da tecnologia mesmo não entrou quase pra atenção primária, né? A gente ainda trabalha muito do jeito...

Entrevistadora: Papel.

Fabiana: Do papel. Assim, é muito cansativo. Demanda muito tempo pra nós. (Fabiana, enfermeira)

Mas a gente chegar para esse idoso e falar "seguinte, vamos gerenciar o cuidado aqui? Você pode ir para onde você quiser, mas traz a informação, pede para o seu filho trazer uma cópia, deixa eu dar uma olhada no que você está fazendo no outro lugar", que é a referência e a contra-referência. Isso é lindo no papel, maravilhoso, a política, as cartilhas de atenção primária, são maravilhosas, na prática as pessoas não fazem. Eu fico me questionando "se as pessoas não fazem, porque a gente não tem um sistema que faz, um computador que faz?" (Débora, assistente social).

Burocracia, falta de informatização, poucos recursos e alta demanda são problemas na APS brasileira apontada em outros estudos (Campos et al., 2014; Tesser; Norman; Vidal, 2018; Assis; Jesus, 2012), não sendo isolada neste serviço ou restritas à atenção ao idoso. De forma específica, a burocratização em procedimentos e atividades da APS pode levar ainda à perda da "noção das necessidades da pessoa (cidadão), das potencialidades do sistema e da possibilidade de formação de redes de atendimento" (Campos et al., 2014, p. 256). 


\subsection{Rede e intersetorialidade}

Atualmente o sistema de saúde brasileiro organiza-se preferencialmente em redes de atenção, de forma a contribuir com uma melhor coordenação do cuidado e melhores resultados em saúde. Essa rede voltada ao idoso hoje está ampliada, contudo ainda apresenta fragilidades pelo olhar dos entrevistados. Nas narrativas é relatada desarticulação entre os pontos da rede, por falta de referência, contra referência e por uma alta hospitalar desintegrada - não se contacta o serviço que novamente irá receber o idoso com possíveis novas necessidades de saúde após uma internação. Por conta dessa desarticulação, além de prejuízos na coordenação do cuidado, a gestão dos recursos também fica debilitada, pois, por exemplo, alguns pacientes que poderiam estar só na atenção primária permanecem na terciária ou secundária, impedindo a acesso de novos usuários nos demais pontos da rede.

Outra limitação que eu sinto muito aqui, que não tinha lá [na Itália], é não ter nenhuma contra referência, nenhum tipo de retorno. Então o único retorno quando eu mando um paciente pra um especialista, pra um hospital, pra... É a fala do paciente. E é uma coisa que me limita muito. Eu não poder passar o caso e não ter nenhum retorno. (Andrea, MFC).

Infelizmente a gente não tem um suporte tão claro de conseguir mandar, para onde eu mando um paciente que eu diagnostico um Alzheimer se os serviços terciários estão todos cheios ... você manda para a atenção secundária, para a $\mathrm{URSI}^{33}$, para o $\mathrm{CRI}^{34}$, para o $\mathrm{AME}^{35}$ do Idoso, esses serviços ficam com o paciente de 6 meses a 1 ano, fazem um plano terapêutico e devolvem ele para a unidade. Qual a dificuldade maior? No diagnóstico, é a gente conseguir todos os exames em tempo hábil, os exames das causas reversíveis, a neuroimagem é crítica (Daniela, geriatra).

\footnotetext{
${ }^{33}$ Unidade de Referência à Saúde do Idoso. A seguir no trabalho serão especificadas as atividades e atribuições deste tipo de recurso.

${ }^{34}$ Centro de Referência do Idoso: trata-se de um recurso estadual destinado ao atendimento multiprofissional de idosos (com diversas especialidades médicas, odontologia, nutrição, farmácia e terapia ocupacional) e atividades de convivência e promotoras de bem estar. $\mathrm{Na}$ cidade de São Paulo existe um CRI na zona norte e um na zona leste.

${ }^{35}$ Ambulatório Médico de Especialidades. A seguir no trabalho serão especificadas as atividades e atribuições deste tipo de recurso.
} 
Às vezes a gente chega em casa para fazer a visita às escuras porque nem sabe como o idoso saiu da internação. Às vezes a filha fala "nossa, eu perdi o documento da alta, não sei onde está, está lá na casa do meu irmão", aí você fala "meu Deus, o que fizeram com ele?", "ah, mas já teve a visita da EMAD", "já? Que eles fizeram?", "ah, não sei". Aí a gente tem que começar do zero "que que eles orientaram vocês, o que eles fizeram?", olha a política pública, totalmente desarticulada, cada um fez o seu pedacinho, mas não ajudou em nada no cuidado. Articulou o cuidado desse idoso? Para mim, não. Cada um fez sua parte. O hospital teve que desinternar rápido, que é o papel dele, a EMAD fez a visitinha para avaliação e ver qual o caso, aí vai montar a programação e a UBS, a ACS chega "o idoso acabou de chegar, vamos lá?", "vamos". O que foi articulado no cuidado? Se ele sai de uma internação, o cuidado tem que começar a ser articulado no leito com as equipes, aonde ele vai. Às vezes o hospital manda a assistente social ligar para mim, minha colega liga "olha, ele vai sair de alta, o que que tem aí para a gente oferecer para ele?", eu "opa, aqui não é comércio onde você escolhe o serviço. Vamos conversar? Me passa o relatório, peraí", "ah, vocês tem assistência 24 horas da Estratégia de Saúde da Família?", "nossa, temos home care até". De fato, não está articulado. Existem serviços, existem. Quando eu falo referência e contra-referência, na verdade, a palavra que eu quero usar é articulação. Temos serviços excelentes, mas estamos muito aquém de ver serviços trabalhando com outros serviços, articulado mesmo. Eu entendendo que faz parte do meu trabalho me articular na rede mesmo, todo mundo estar ciente que está acontecendo, não é assim, não é. A gente é pego muitas vezes de surpresa, assim como às vezes a gente deixa os outros serviços serem surpreendidos, não tem que ser assim. Acompanho o idoso há dez, vinte anos aqui. Se ele vai para uma internação daquele jeito no mínimo que eu mande um relatório com o último histórico, fale assim "gente, somos a estratégia, estamos acompanhando, o relatório está aqui", "ah, aconteceu isso, isso", "tem possibilidade de alta?", "tem, possibilidade de alta para daqui alguns dias", a partir daí vamos montar o cuidado? Vamos preparar a família? (Débora, assistente social).

Além disso, há desconhecimento quanto a todos os equipamentos sociais disponíveis para as equipes, tanto da rede de saúde quanto os disponíveis na comunidade.

Então, eu sinto falta desse apoio da rede, viu? Parece que a rede é bem pobre, assim. Eu não consigo enxergar nada além desses dois apoios, assim. Claro, a gente tem a equipe multi dentro do posto, né? Dentro do centro de saúde. Mas a rede mesmo, vendo assim a parte mais ampla, não tem muito apoio, não. (Carolina, enfermeira)

Entrevistadora: Além de passar na equipe, que mais de recurso você sabe que existe ou que você costuma chamar para pedir ajuda? 
Laura: Ai, só esses só, não tem mais nada, que eu saiba não. (Laura, ACS).

Lá eu não sei exatamente o que eles fazem, mas eu sei que é artesanato, várias coisas. E essa paciente, ela vai. Inclusive ela fala muito bem, ela é professora. Então ela dá, faz... Ela também ajuda eles lá. Porque ela acaba fazendo o trabalho dela, que ela já fazia, e isso faz com que ela ajude as pessoas e ela também. Então tem várias coisas, a gente tem várias coisas que eu não sei o tanto que a gente tem. Mas a gente tem bastante coisa que a gente pode encaminhar os pacientes pra... (Dulce, técnica de enfermagem).

Mas, assim, da minha área eu sei que não tem. Não recordo. Tem uns idosos que fazem caminhada independente, né? Tem uma praça próximo da residência do pessoal ali do Bom Retiro tem uma praça. Eles fazem atividade lá. Mas, assim, de recurso que tem alguém que faça uma atividade, alguma coisa, eu acho que não tem. (Rafael, ACS).

Por outro lado, quando bem articulado ou quando a equipe é apresentada aos recursos, é possível uma melhor utilização do mesmo.

E aí a nossa dificuldade da URSI é o tempo de espera, demora de 4 a 5 meses para a gente conseguir, demora demais. Em contrapartida, um dispositivo muito legal que acabou de aparecer para a gente. Fomos apresentados para ele, tivemos uma reunião no final do ano passado, que é o AME do Idoso da Lapa, que aí ele é SPDM ${ }^{36}$, é um AME, só de idoso. Lá tem várias especialidades médicas, não só tem o geriatra, tem uro, tem cardiologista, tem onco-clínico, tem exames laboratoriais, tem equipe multi, tem arte-terapia, terapia ocupacional, fisio, ginástica, treino cognitivo, lá é uma assistência muito legal, ampla, e a gente consegue consulta para a semana seguinte . (Daniela, geriatra)

Apesar da diversidade de programas e políticas voltados aos idosos, o engessamento de critérios para ingresso em alguns dos recursos também interfere no acesso aos mesmos, especialmente quando se considera na equação a heterogenia do idoso e do processo de envelhecimento, que acarreta demandas muito específicas.

Assistência domiciliar, por exemplo. A EMAD tem critérios extremamente fechados. É uma organização linda, mas tem critérios

36SPDM: Associação Paulista para o Desenvolvimento da Medicina. Trata-se de uma Associação civil sem fins lucrativos, filantrópica, que presta serviços para o Sistema Único de Saúde. 
muito, muito restritos. Antes de tudo, tem que ter o cuidador, que é a nossa maior dificuldade. Muitas vezes a pessoa mais complicada, mais difícil, não tem o cuidador e isso só descarta a possibilidade da EMAD. Às vezes, não é um cuidado de tão alta complexidade que demanda a EMAD. Então, às vezes, precisaria de algum tipo de assistência que tenha pelo menos uma enfermagem, mas que consiga dar 0 acompanhamento mais frequente do que uma equipe da estratégia consegue. Isso tô falando só do sistema de saúde. Acho que é o principal, né? (Andrea, MFC)

"Não, ele não precisa de fralda, é preguiça, ele tem que acordar e assim como o senhor pede de manhã tem que pedir à noite também", aí foi negado o pedido das fraldas e, coitada, ela falou "não, eu quero fralda porque para mim é bem melhor porque daí eu troco a fralda e não fico molhada, não tenho que lavar" (Carla, ACS - quando o fornecimento de fraldas foi negado ao idoso e, ao olhar da equipe, pelas dificuldades da cuidadora, deveria ser fornecida. A cuidadora era idosa e dormia na mesma cama que o idoso, que realizava suas eliminações fisiológicas no leito a noite, de forma que ambos acordavam molhados pela urina).

É, mas eu já requeri porque ela fez uma carta dizendo como se eu tivesse desistido, eu falei que não vou assinar essa carta, eu não desisti, quem tá, como se diz, negando essa refeição, são vocês. (Carmen, 90 anos - ao relatar que foi negado o almoço oferecido pelo programa Alimentação Sobre Rodas porque essa refeição era realizada no Centro Dia, mas a idosa guardava esse almoço para comer no jantar).

Outra dificuldade apontada é o descompasso entre oferta e demanda: poucas vagas para o contingente que necessita dos mais variados tipos de suporte. Tempo longo de espera ou mesmo a impossibilidade de acessar a rede são apresentados pelos profissionais.

Fernando: No cuidado com o idoso eu acho que o mais difícil é esse suporte secundário que a gente precisaria ter. O PAl é bem interessante, é um programa muito bom, mas em alguns casos não é suficiente, a gente sabe, principalmente em casos de abandono mesmo. Como equipe a gente consegue atuar, mas não consegue estar $100 \%$ do tempo lá e os pacientes que precisam de alguma internação, alguma coisa, aí são poucos os casos que a gente consegue ter resultado. $E$ acho que um outro suporte também de... a gente sabe que tem o Centro Dia, né, que alguns idosos conseguem a vaga, inclusive idosos vão bastante, mas não são todos os idosos que conseguem. 
Entrevistadora: De suporte secundário o que você mais usa é o PAI e qual mais?

Fernando: É o PAI, a URSI para pacientes frágeis que não conseguem caminhar e o Centro dia, como eu disse, acho que só.

Entrevistadora: E você conseguiu encaminhar alguns para a URSI já? Fernando: Já, mas são poucos.

Entrevistadora: Por que? Pela questão de vaga?

Fernando: Acho que questão de vaga, eles limitam para os pacientes que estão piores, então não todos que conseguem, acho que é questão de vaga mesmo. (Fernando, MFC).

Bom, isso até tá sendo bastante discutido na prefeitura, uma das reuniões que a gente mais foi esse ano, foi pra falar de idoso. Que é meio que a bola da vez, assim, né? Principalmente, em relação aos equipamentos, os programas que vão compor a rede, né? Viu-se que a rede do município, ela é muito pequena perto da demanda que a gente tem e sabe-se que a demanda só vai aumentar, né? A população idosa só vai aumentar. (Fabiana, enfermeira).

Que nem esses que têm dificuldade pra andar. Vai encaminhar pro $\mathrm{CER}^{37}$ ? Sim. Não tem mais vaga. Você vai encaminhar pra lá? Não tá aceitando. Quer dizer, então o que que você faz? Tá alimentando. Tem expectativa, sim. Mas concreta é muito difícil. Mas só de você ter esperança, eu acho que já é uma grande coisa.(Martha, ACS)

Factualmente um dos principais desafios para a assistência ao idoso atualmente é a limitação de oferta de recursos frente a uma demanda crescente. Além do aumento decorrente da transição demográfica, pelas próprias características do envelhecimento (multimorbidade, doenças crônicas, necessidade de acompanhamento constante, etc.) há maior volume de internações, de tempo de ocupação de leitos e consumo em geral dos serviços de saúde (Veras; Oliveira, 2018) sobrecarregando o sistema. Para Lima (2003), os programas de saúde para os idosos ainda são majoritariamente voltados para o controle de riscos e doenças crônico-degenerativas, carregando mais a tradição da organização do trabalho centrado no atendimento médico e muito menos nos determinantes sociais, reduzindo o envelhecimento a um de seus traços apenas que é a doença crônica. Com foco maior em doença, há multiplicação de consultas com especialistas, mais fármacos, exames, e

${ }^{37}$ Centro Especializado em Reabilitação. Trata-se de uma unidade voltada para o atendimento especializado de pessoas com deficiência que necessitam de reabilitação. 
fragmentação da informação, o que sobrecarrega o sistema e não agrega melhores índices de qualidade de vida. Essas limitações são também sinalizadas pelo próprio Ministério da Saúde (Brasil, 2018):

No entanto, considerando as normativas e as diretrizes já publicadas, muitos desafios permanecem. Apesar de alguns avanços, as pessoas idosas e suas especificidades permanecem muitas vezes invisibilizadas, provocando a perda de oportunidades para intervenções sociais e sanitárias adequadas e a sobrecarga dos serviços de saúde especializados, em especial das urgências e emergências, com agravos muitas vezes evitáveis. A prática do cuidado no sistema de saúde permanece fragmentada, com dificuldades para organizar as ações de modo a beneficiar a saúde de forma integral, considerando as especificidades do idoso. Contribuem para esse cenário, a escassez de equipes multiprofissionais com conhecimento necessário em envelhecimento e saúde da pessoa idosa; a insuficiência de estruturas de cuidado intermediário e de serviços de cuidado domiciliar; a existência de profunda desigualdade social, étnico-racial e de gênero; bem como o maior ou menor acesso à rede de atenção à saúde. Esses fatores também contribuem para a maior heterogeneidade do processo de envelhecimento e, consequentemente, do segmento idoso brasileiro. Este cenário impacta diretamente no sistema de saúde, trazendo demandas diferenciadas que exigem respostas mais efetivas para os indivíduos e para a sociedade (Brasil, 2018, p. 8-9).

Em consonância com a percepção dos depoentes, a presença de um suporte para o idoso em rede, articulado e coordenado tem sido apontada como o mais adequado para um cuidado integral e de qualidade para o idoso (Veras e Oliveira, 2018).

O tipo de dificuldade programática relatada foi compatível com o campo de ação de cada profissional. Certamente medidas que atuem em todas as áreas são potentes para o incremento da saúde do idoso. Daí a importância de uma construção coletiva da rede de assistência, desde programas internos à comunitários, com usuários, profissionais das diversas áreas e gestores, e diversos atores da sociedade civil para maior efetividade e visão abrangente das diferentes necessidades e prioridades. 


\subsubsection{Autonomia, Cuidado e os caminhos trilhados nos desafios da atenção ao idoso na Atenção Primária à Saúde}

Nas entrevistas, atendimentos, discussões de casos, grupos, conversas no serviço, exploração do território, visitas domiciliares, reuniões de equipe e do centro de saúde, diversas estratégias utilizadas diante dos desafios e facilidades no cuidado do idoso foram identificadas. Essas práticas serão aqui apresentadas sob o quadro conceitual de Cuidado partindo da narrativa de algumas dessas histórias, sendo interessante assinalar que vários desses procedimentos, mesmo utilizados de forma espontânea e ingênua, alinham-se com o que se procura resgatar com o conceito do Cuidado. "Trata-se de fazer mais e, algumas vezes, um pouco diferente, aquilo que já sempre terá feito parte da arte da atenção à saúde" (Ayres, 2009b, p. 18).

Rafael: Olha, tem um paciente que vai fazer um ano que eu consegui fazer ele sair de casa pra me atender no portão. Porque há três anos que eu tô nessa micro área, ele nunca abriu nem a porta pra mim. Era pela janela, dentro do portão que ele me recebia.

Entrevistadora: $E$ o que que você fez que mudou com ele?

Rafael: E aí eu comecei a conversar, mesmo pela janela. Perguntava pra ele "Tudo bom com o senhor? O senhor tá bem?" "Ah, tô bem." Fechava a janela. [Eu] Falava "Não. Tem alguma coisa." Aí, passava o mês seguinte "Tudo bom?" "Tudo bem." E numa dessas "Oi. Tudo bom? Tudo bom?" Eu vi que tinha uma equipe do $\operatorname{SASF}^{38}$ que também fazia visita para ele e que ele também recebia da mesma forma. Eu falei "Então vamos juntar uma coisa com a outra." O SASF vai fazer visita, então vou chamar o SASF pra vir aqui, pra eles explicarem o caso, pra ver o que a gente consegue fazer em conjunto. Aí conversei com a equipe, a equipe aceitou, o SASF também aceitou. Fizemos uma reunião, conseguimos conversar com ele, marcamos uma consulta pra ele. Aí, conseguimos conversar entre o SASF e nós. Até que chegou o ponto que falei "Ó, então a gente vai ter que conversar, agora, com ele." E aí nós conseguimos o telefone acho que de um irmão dele e esse irmão dele falou assim: "Pode ir lá, que eu vou tá lá pra receber vocês." No dia que nós fomos, o irmão não foi. E ele não abriu a porta. A gente via que ele estava em casa, ele não abria a porta. Aí a gente falou "Bom, a gente vai ter que fazer alguma forma pra ver o que que a gente consegue." E aí eu consegui entrar através de uma vizinha, que ela conversou com ele no período que nós não estávamos lá na área.

\footnotetext{
${ }^{38}$ Serviço de Assistência Social à Família e Proteção Social Básica no Domicílio. Desenvolve ações de proteção social básica no domicílio e se destina a famílias em situação de vulnerabilidade social.
} 
Aí ela me trouxe a devolutiva "Vai tal dia, que ele falou que vai receber você." E aí ele veio até o portão e onde, realmente, eu pude ver quem era a pessoa que tava atrás do portão. E aí vi que ele precisava de muitos cuidados, precisava passar em consulta até praticamente com urgência, porque tava bem debilitado. $E$ aí eu cheguei aqui no posto e falei "A gente precisa, de fato, fazer alguma coisa, porque ele tá num estado bem de calamidade pública, sabe? Aparentemente ele tem alguém que dá um suporte pra ele, mas ele tá totalmente descuidado, literalmente." Ele abriu o portão, levei um susto. Primeiro, com a imagem que eu vi, de um idoso com uma roupa toda suja, com um odor muito forte, muito desorganizado, confuso, perdido. E aí eu consegui fazer com que ele viesse no posto. $O$ irmão dele trouxe ele no posto. Ele passou em consulta. Fizemos encaminhamento pra vários lugares. Mas ele sempre negando tudo. "Não vou. Não vou. Não vou. Não vou." E depois de um tempo, ele começou a vir me receber na porta, começou a receber equipe do SASF. Conseguimos fazer algumas mudanças na alimentação. Conseguimos solicitar Alimentação sobre Roda pra ele. Mas ele também não queria. Depois de um tempo ele aceitou. Depois ele desistiu de novo. A gente não sabe nem se ele tá ou se ele não tá. Porque fica naquilo "O senhor tá recebendo comida?" "Ah, tô." Aí você pergunta pro pessoal da Alimentação Sobre Rodas: "Não. Não tá recebendo." Então, assim, tá difícil, assim. Mas, assim, a gente conseguiu ver uma grande evolução. Ele conseguiu já, pelo menos já receber-nos, conversar, explicar se tá bem, se não tá bem. Eu acho que de todos esses casos que eu tive, foi o que eu mais me vangloriei por ter conseguido mover uma ação e tá tendo resultados. Pequenos, pontuais, mas tá tendo, né? Pra começar que ele nem saía, praticamente, de casa e já vir até aqui, já é um grande começo, já, né?

Entrevistadora: Ele chegou contar porque que ele não recebe? Você chegou a perguntar?

Rafael: Ele sempre referiu que ele era muito autônomo. Ele não precisava de ninguém. Ele era totalmente independente. Ele não precisava de ninguém. $E$, agora, ele chegou numa situação que ele tá precisando de ajuda. E foi quando ele me recebeu, quando ele veio conversar comigo na porta. Então ele falou: "Olha, eu sei que agora tô precisando de ajuda. Você passa todo mês aqui, vai fazer anos que você passa aqui. Eu sempre te vejo pela janela. Mas é que, agora, eu tô precisando mesmo de ajuda." Aí no dia seguinte mesmo, eu já levei uma convocação pra ele, falei "Ó, já tem uma consulta marcada pra tal dia." E aí o irmão dele, também, em contrapartida, também já tinha entrado em contato com ele. Aí o irmão dele também veio aqui e conversou com a gente. Mas foi umas quatro semanas de correria mesmo, pra poder articular tudo, pra ele poder chegar aqui e ter uma estrutura, pra ele poder passar e poder se abrir, né? Sabemos que não contou o total. Mas, assim, já foi uma grande evolução (Rafael, ACS).

No caso relatado por Rafael foram apresentados diversos dos percursos utilizados pelas equipes. O primeiro trajeto que se realça no caso foram os passos dados em prol da construção de vínculo. 
Classicamente a noção de vínculo está associada a uma relação de confiança pessoal, estreita e duradoura entre os indivíduos (Brunello et al., 2010). Sua construção é parte dos pressupostos da Medicina Centrada na Pessoa (MCP), um dos pilares da Medicina de Família e Comunidade através do quarto componente "intensificando a relação entre a pessoa e o médico". $O$ vínculo é determinante, inclusive, da qualidade da parceria para realização de um plano terapêutico compartilhado (Stewart et al., 2017). Gomes e Pinheiro (2005) partilhando de concepções para a Integralidade compartilhadas com Mattos apresentam sentidos da Integralidade que compartilham horizontes com o quadro do Cuidado e fazem referência à perspectiva do vínculo. Dentre os conjuntos de sentidos da integralidade, expõem esta como uma característica da boa medicina. Neste conjunto, a "integralidade está presente no encontro, na conversa, na atitude do médico que busca prudentemente reconhecer, para além das demandas explícitas, as necessidades dos cidadãos no que diz respeito à sua saúde" (Gomes; Pinheiro, 2005, p. 290), práticas estas que favorecem a construção de uma boa relação entre profissionais de saúde e pessoas ou mesmo comunidades. Ayres, por sua vez, acrescenta que

a ideia de vínculo remete a algumas práticas e atitudes fundamentais para a realização do cuidar: abrir mais espaço para os usuários como verdadeiros sujeitos, e não como objetos de intervenção; mais continência e continuidade no serviço às diferentes demandas de indivíduos e comunidades; promover um efetivo envolvimento de profissionais e usuários ou comunidades com os processos de cuidado. Aqui, mais uma vez, é fazer mais e melhor do que já sabemos fazer, mas também fazer diferente, ou talvez compreender de outra forma esse fazer. (Ayres, 2009b, p. 19).

Diversos movimentos realizados em prol do vínculo evidenciado nesse caso serão apresentados a seguir. $O$ primeiro aqui sinalizado foi $O$ de continuidade e constância. A partir de tentativas de encontros em visitas domiciliares e, posteriormente, por meio de pessoas com as quais o idoso já possuía uma relação de confiança, conseguiu-se uma intensificação do relacionamento. Em outros relatos há a mesma experiência. Em geral, são acionados vizinhos ou algum outro familiar que já tem um bom relacionamento com a equipe e sabidamente com o idoso. Nas narrativas, essa pessoa chave foi 
instrumento para convencer o idoso a aceitar alguma visita ou pequena intervenção. Trata-se de uma ferramenta importante especialmente quando se tem celeridade nos casos, já que, em especial na questão do idoso, por questões de fragilidade, uma situação pode exigir uma urgência maior, o que nem sempre viabiliza todo o tempo necessário para a construção de um vínculo inicialmente já com o idoso.

O uso das visitas domiciliares é muitas vezes citado nas entrevistas. Realizadas por todos os profissionais da eSF, as visitas proporcionam um contato num ambiente externo ao serviço de saúde, possibilitando uma aproximação maior com a realidade do indivíduo. Considerando-se as transformações nas necessidades de saúde da população brasileira, especialmente com aumento dos atendimentos voltados aos idosos, de pessoas com condições crônico-degenerativas ou com sequelas de acidentes, ou doenças, a atenção domiciliar se sobressai como possibilidade de resposta do SUS. Ela é uma das atividades previstas para os profissionais da APS e é desempenhada em sua maior parte nesse nível de atenção do sistema de saúde, embora não se limite a ele. A visita domiciliar. Por sua vez, é parte da atenção domiciliar. É realizada por todos os profissionais da ESF, com frequência mensal pelos ACSs e variável pelos outros profissionais, a depender da complexidade clínica, de contexto social, de família, etc. Por meio dela é facilitada a ampliação ao cumprimento de princípios do SUS, como equidade, integralidade e atributos da APS, como a longitudinalidade. Além disso, quando inserida nas linhas de cuidado e baseada nas necessidades das famílias, minimiza a fragmentação do cuidado e possibilita a superação de algumas limitações de acessibilidade ao serviço, quando presentes (Brasil. Ministério da Saúde, 2020). Por essas características, é um recurso potente para o cuidado do idoso. Por meio delas, quando há limitações de acessibilidade ao serviço, é possível que as mesmas sejam transpostas pela própria equipe. Neste CS em especial, pela presença dos estagiários de graduação, foi citado também o envio de estudantes acompanhados por outros profissionais da equipe para uma avaliação clínica e de contexto social e relacional mais minuciosos em casa (já que nem sempre se tem tanto tempo nas consultas realizadas na unidade saúde). No relato abaixo, as visitas frequentes também foram importantes na 
criação e manutenção do vínculo, relacionadas a disponibilidade de consultas na UBS com maior duração de tempo e escuta qualificada e atuação em rede e interprofissional (como será discutido adiante).

É uma consulta muito mais tranquila [quando tinha disponível uma agenda específica para avaliação do idoso], que a gente tinha até uma hora, às vezes. A gente pegou uma hora, que dá pra conversar, deixar o paciente falando tudo que fala, perguntando sobre... Aqui se dava pra perguntar os passados e os planos para o futuro. Até isso foi mudando. Porque os planos para o futuro dele, por exemplo, na primeira consulta era comprar um terreno e uma casa na Bahia, onde ele nasceu pra ser enterrado lá. A fala dele era ser enterrado nessa terra. Aí, já quando, nos retornos esses planos foram mudando. Ele tava querendo sair do apartamento onde ele tava morando de favor pra conseguir algum lugar, conseguir voltar a ter uma independência econômica, pra mudar de casa. Já tava planejando outras coisas um pouco mais a longo prazo. E esse acho que foi uma das principais, dos principais motivos dele se sentir acolhido: as visitas da agente comunitária foram muito mais frequentes, no começo principalmente. Ela ia quase semanalmente. Às vezes, nem entrava, mas já passava lá "Tudo bem? Como tá?" Tocava na porta e ele muitas vezes ficava na rua. Então, ele fez bastante vínculo com a equipe. E o programa do PAl foi ótimo pra ele. Foi o que melhorou muito. Ele veio muito satisfeito com isso. A físio também entrou na questão. (Andrea, MFC)

Além da constância ou da persistência, por meio de visitas domiciliares, por exemplo, as equipes se utilizaram de recursos pessoais como a manutenção da esperança (o não desistir de um caso por parecer insolúvel) e da insistência, como na fala de Martina "então a gente começou a tentar um pouquinho mais, insistir, apertar um pouquinho mais e aí começou a dar certo" e de Martha:

"Do que depender de mim, eu vou fazer." $E$ faço. O que depender de mim, eu faço, entendeu? A gente não pode viver sem esperança. A gente tem que ter uma válvula de escape. Se não der isso, vamos tentar isso. Vamos tentar aquilo. Se não der com a assistente social, vamos falar com o fisio (Martha, ACS)

Também há perseverança em continuar orientando, porém, mudando a forma de falar (mesma informação, mas processada a partir de outras palavras ou outra entonação, procurando entender de qual forma consegue-se ir além na linguagem, não só verbal, que de fato afeta ou mais motiva o indivíduo para a realização de determinada ação), ou trocando o profissional que estará mais envolvido com o caso em cada momento (exemplo: começa com agente 
comunitário, depois mais visitas pelos técnicos de enfermagem, visita médica, avaliação com psiquiatra e assim por diante).

\begin{abstract}
A gente, por exemplo, a gente tenta fazer um rodízio entre os profissionais pra fazer essas tentativas, vai, vamos dizer. E não coloca muito prazo. Eu acho que cada família tem seu tempo, também, né? Algumas acabam querendo mudanças logo ou querendo fazer coisas rápido. Outras, a gente vê que tem um processo mais lento. Então, às vezes, cê propõe e a família não aceita, o paciente não aceita. Aí a agente comunitária vai lá, conversa mais um pouquinho, o médico vai lá, conversa mais um pouquinho. E a gente vai tentando. Mas em algum momento a gente: "Ah, tentamos, tentamos. Fomos ao limite né? Deixa como tá." (Fabiana, enfermeira).
\end{abstract}

Ressalte-se, contudo, que em algumas situações mesmo nesse processo de persistência, as equipes entendem que chegaram no limite daquilo que conseguiriam fazer. Para alguns, esse entendimento vem associado a fracasso, tristeza, frustração e, principalmente, sensação de impotência. Outros, por outro lado, lidam entendendo que fizeram ou possível convivendo com a situação com maior tranquilidade.

É como se a gente não tivesse fazendo o serviço direito, né? Que a gente não tivesse conseguindo transmitir a importância da saúde, do cuidado. Mas, ao mesmo tempo que eu me sinto assim, eu me sinto que eu fiz o melhor. Mas não tenho como fazer além do que chegou ao meu ponto, entendeu? Então, assim, eu me sinto triste, porque eu queria poder ajudar todos. Conseguir, igual aqueles que a gente consegue compensar, aqueles que a gente consegue melhorar a vida deles, assim, $80 \%$ do que era e aí a gente vê esse que a gente não consegue, é essa sensação de não tá fazendo o trabalho direito. Mas aí, ao mesmo tempo, eu olho: "Não. Eu tô fazendo o trabalho direito, só que pessoas são diferentes. Pensamentos são diferentes." (Dulce, técnica de enfermagem)

Outros recursos também são utilizados para construção do vínculo. Alguns profissionais referem fazer uso da empatia e de vivência pessoal ou experiências próprias, tornando o contato com o usuário mais pessoal, caloroso, do que apenas o regido pela conformidade estritamente profissional. Os idosos manifestam que o amor, o carinho e o sentir-se bem acolhido pela equipe são factualmente importantes na relação que denota bom vínculo. 
E modéstia à parte, assim, eu adoro atender, atendo muito bem. Gosto muito de atender idoso. Gosto muito de criança e de idoso, né? Então adoro. Até por conta que eu morei com meus avós, fui criada por eles. Então eu acho que um carinho mais especial. Então eu sempre procuro ver no idoso que eu atendo, que eu vou na casa, né? Como se fosse meu avô, minha avó mesmo. O que eu gostaria de fazer pelos meus avós e como eles deveriam, gostariam de sentir também, né? Quando eu vou lá, quando eu converso, dou bronca em alguns, como eu dava nos meus avós também. Então eu acho que eu trago mais, um pouco, pro lado pessoal mesmo, né?(Carolina, enfermeira).

Não, a gente é amiga, quero muito bem elas e eu sinto que elas me querem, até médica, pois eu dei uma reunião, meus 90 anos, meu filho ofereceu num restaurante, infelizmente as meninas não puderam ir, porque nós convidamos, porque houve essa mudança, o prefeito mudou o sistema e elas não puderam ir, mas a médica foi com a filha dela foi me cumprimentar, não ficou, mas foi me cumprimentar, e quem faz isso? Mas é porque é gente com amor, a gente que eu falo... aqui quando elas vem hoje eu nem sabia, a J. faz bolinho de chuva, eu já tenho feito pão de queijo, eu deixo na geladeira para servir, é uma amizade sempre, o ano retrasado fizeram uma festa de aniversário para mim aqui surpresa e eu nem sabia, quer dizer eu tenho essas coisas que eu digo, agradeço a Deus todo dia, essa... ai meu Deus faltou a palavra, esse carinho que a pessoa dá para mim, eu agradeço todo dia todas elas (Rute, 90 anos).

O idoso é um paciente difícil de trabalhar porque ele tem uma história de vida, uma crença, eles carregam uma grande bagagem quando vêm na consulta. Você tem uma grande responsabilidade por lidar ali com uma pessoa que às vezes não vai nem acreditar no que você está falando, mas dependendo do profissional que você for, ela acredita, fazer o vínculo sabendo como lidar com esse paciente é muito importante para o profissional, isso depende muito do cuidado dele. Esse olhar de que você sabe que um dia será idoso e vai depender do cuidado de alguém, isso você também traz para o consultório, você sempre tem que se colocar no lugar da pessoa e trabalhar em cima disso. (...) Esse se colocar no lugar do paciente, onde você está sentada, é muito importante, acho que a partir daí que você vai tomar as atitudes do que é melhor para ele, não para mim. (Martina, enfermeira).

Em outros casos também foi citado o sucesso da construção de vínculo a partir da associação com outras equipes de saúde, além da facilitação mediada por alguém de convívio do usuário, como anteriormente citado. 
Entrevistadora: E como que foi pra pactuar quando a irmã faleceu? Aí vocês chegaram, foram conversando, teve resistência, não teve? Como é que foi?

Fabiana: No início, teve um pouco. Porque ela, também, é um pouco confusa. Mas acho que a grande parte desse convencimento foi com um acompanhante do PAI, quando ela fez o vínculo... (Fabiana, enfermeira, 37 anos).

Esperar o tempo certo da pessoa também foi fator importante para a construção de vínculo e da preservação do respeito a quem é a pessoa. O idoso do relato conhecia quem era a equipe e sabia como fazer uso dos recursos oferecidos se necessário, já que recebia as visitas com frequência. Ao entender que havia chegado o momento de pedir ajuda, se abriu para as possibilidades oferecidas pelo serviço. A persistência, o deixar "a porta aberta" e aguardar o tempo de cada pessoa são importantes no Cuidado e na construção de uma autonomia relacional.

Entrevistadora: $\mathrm{O}$ que que te ajudou depois desses três anos que a $\mathrm{L}$. faleceu?

Carmen: A frequência...

Entrevistadora: Como a senhora foi resolvendo a vida?

Carmem: Já vieram aqui várias pessoas do Centro do Bom Retiro, UNIBES $^{39}$, você conhece?

Entrevistadora: Uhum.

Carmen: Vieram aqui, eu não queria, porque eu queria continuar vivendo aqui, apegada às coisas e apegada à L. que ficou na minha cabeça, no meu peito o tempo todo, mas depois eu caí na real, eu achei que eu não devia ficar nesse estado né, de depressão, ai eu fui lá pro Centro e passo...

Entrevistadora: Que é o Centro Dia...

Carmen: Que é o Centro Dia para idoso, passo o dia todo lá, e me sinto muito bem porque as meninas cuidadoras são muito boas, e os idosos gostam muito de mim, logo que eu entrei todos escreveram uma cartinha de boas-vindas para mim, mas quando eu vou chegando em casa eu começo a ficar deprimida, sabe, eu chego, eu saio as 8 da manhã e saio as 4, 4:30 da tarde lá, mas chego aqui quase 7 horas da noite, porque tem gente que mora em Cambuci, sabe, em lugares distantes.

Entrevistadora: E como que a senhora conseguiu a vaga lá?

Carmen: Eles que me chamaram pela segunda vez, ai eu aceitei ir, porque eu estava muito só. (Carmen, 90 anos)

${ }^{39}$ União Brasileiro Israelita do Bem Estar Social. O Centro ao qual Carmen se refere é o Centro Dia. Este foi desenvolvido como uma parceria entre a Prefeitura de São Paulo e o UNIBES. 
Além da espera pelo tempo ideal para o usuário, é apresentado no caso de Rafael, a importância de se ter um bom acolhimento: chegado o tempo em que o idoso entendeu que precisava de ajuda, foi de suma importância organizar 0 atendimento para que não se quebrasse o vínculo ainda incipiente.

Divulgado e recomendado no SUS por meio da Política Nacional de Humanização, o acolhimento diz respeito tanto à forma de arranjo institucional, quanto de trabalho, ampliação de acesso e concretização da APS como principal "porta de entrada" no sistema. Para adequada realização, faz-se necessária aplicação de técnica (para identificação de necessidades mais ou menos prementes e eleição de prioridades, percepção de necessidades clínicobiológicas, psicossociais e epidemiológicas), mas também de sabedoria prática e uma postura ética, humana, empática e respeitosa ao usuário (Tesser; Neto; Campos, 2010). Por essas características, o acolhimento se propõe a uma inversão da tradicional lógica de organização e funcionamento dos serviços de saúde para que sejam centrados nos usuários (Gomes; Pinheiro, 2005) e otimizem a interação entre estes e os serviços (Ayres, 2004a).

Essencial para garantia do acesso na atenção primária, o acolhimento no centro de saúde é apontado também por outros profissionais como um fator que requer aprimoramentos para melhoria do cuidado da saúde do idoso. Uma das equipes, nesse movimento de tentativa de melhora, passou a utilizar o acesso avançado, pelo qual, nessa equipe, as consultas médicas e de enfermagem são agendadas em até 48 horas.

É difícil trabalhar com agenda para três, quatro meses, é muito distante, problema para os nossos pacientes. A gente via que antes não dava muito certo, a dificuldade que a população tinha para agendar consulta, o que tinha de reclamação, aí com o acesso avançado melhorou bastante. (Martina, enfermeira).

Eu acho que aqui no serviço o que falta é uma equipe pra acolhida, sabe? Pra fazer o acolhimento de qualquer pessoa que venha, sabe? Às vezes, a pessoa chega pra conversar com o agente comunitário. A pessoa não escutou direito o que que você falou: "Ah, vai na sala 3." Mas, tipo, o agente comunitário não fica na sala 3, entendeu? É tipo, aquele negócio, você não tem o acolhimento, a escuta do que precisa ser feito. Digo caso de idosos também. Às vezes, ele quer pegar receita que tá no prontuário. "Ah, não. É na farmácia pra pegar remédio." Não. Mas ele não quer pegar o remédio. Ele precisa pegar a 
receita. Então acho que, realmente, no serviço, num todo, falta um aperfeiçoamento de acolhimento. (Rafael, ACS)

Na narrativa de Rafael houve discussão do caso entre os profissionais da equipe de Saúde da Família e entre essa e o SASF. O trabalho em equipe foi o recurso mais frequentemente citado pelos profissionais para lidar com o cuidado do idoso. Inerente ao trabalho na ESF, a prática de compartilhamento dos casos permite enriquecer horizontes, já que cada profissional possui diferentes formação, experiências e vivências. No CS, além da equipe de saúde da família, conta-se com reuniões semanais da equipe com assistente social, psiquiatra, psicólogo (estes três profissionais na mesma reunião, pela frequente associação das situações que envolvem ações de todos esses profissionais), geriatria e fisioterapia. $O$ encontro com a equipe ampliada (não funcionando nesta UBS como NASF-AB) ocorria em espaços informais (trocas entre um atendimento e outro) ou formais dedicados ao matriciamento: em reuniões de discussão de casos, educação continuada, atividades na comunidade e atendimentos compartilhados (atendimentos simultâneos ou propostas de atendimentos por outro profissional com compartilhamento das informações e reestruturação do seguimento),

\begin{abstract}
A gente compartilha o caso e tentamos resolver ou manejar o máximo que é possível na clínica, né? $\mathrm{E}$ as questões sociais, a gente vai pensando junto em como proceder. Então além o PAl, se é um caso que eu acho que de cara eu já vejo que o paciente tem potencial pro PAI e acho que seria interessante, eu já ofereço logo na primeira visita. Se é um caso que tem algum conflito familiar ou alguma questão de cuidado. Por exemplo, um caso de um idoso que tá abandonado, tá negligenciado e tem família, a gente traz isso pra discussão na equipe e, muitas vezes, a gente pega os contatos dos familiares e assistente social acaba fazendo um primeiro contato pra uma reunião, pra ver 0 que que acontece, porque que está nessa situação... (Fabiana, enfermeira).
\end{abstract}

Para uma orientação a um Cuidar efetivo, com interações intersubjetivas ricas e a presença ativa do outro, é necessário que os horizontes, tanto da racionalidade das tecnologias quanto dos indivíduos que as operam, sejam expandidos. Para isso, deve-se ir para além da orientação individual no cuidado e partir para esferas coletivas e institucionais, sendo o trabalho em 
interdisciplinaridade e intersetorialidade, além da pluralidade dialógica, inerente ao alcance do êxito nesse enriquecimento de horizontes. $O$ trabalho na ESF, por sua estrutura, potencializa as ações de interdisciplinaridade e requer a intersetorialidade para alcançar sucesso prático (Ayres, 2004a). A atuação da equipe multiprofissional pode potencializar as ações e os serviços no sistema de saúde, devido ao compartilhamento de informações e a superação do isolamento dos saberes. No Centro de Saúde, o recurso dessa interação comunicativa e da articulação de ações dos diversos atores da equipe mínima e dos profissionais de apoio favoreceram a superação de algumas dificuldades no cuidado do idoso. Assim o trabalho em equipe e o apoio matricial (ou matriciamento) nos casos proporcionou aquilo ao que se pretende: retaguarda assistencial e suporte técnico-pedagógico para as equipes de referência (Campos; Domitti, 2007). Ainda, sobre o trabalho em equipe Campos e Domitti afirmam que:

\begin{abstract}
A composição da equipe de referência e a criação de especialidades em apoio matricial buscam criar possibilidades para operar-se com uma ampliação do trabalho clínico e do sanitário, já que se considera que nenhum especialista, de modo isolado, poderá assegurar uma abordagem integral. Essa metodologia pretende assegurar maior eficácia e eficiência ao trabalho em saúde, mas também investir na construção de autonomia dos usuários. Sua utilização como instrumento concreto e cotidiano pressupõe certo grau de reforma ou de transformação do modo como se organizam e funcionam serviços e sistemas de saúde (CAMPOS; DOMITTI, 2007, p. 400)
\end{abstract}

Outro ponto interessante observado durante o campo é a existência de uma reunião mensal (duração de um período de 4 horas) denominada "Reunião de Ensino". Voltada aos profissionais e estagiários de graduação, na reunião são abordados temas relevantes para as práticas na unidade de saúde. Em uma das reuniões presenciadas durante o campo, o tema trazido foi justamente sobre a avaliação multi-dimensional do idoso na atenção primária, com discussão de caso clínico. É uma ação importante para a capacitação dos profissionais e o processo de educação permanente e também atua em prol de um enriquecimento de horizontes técnico e de saberes. 
O uso de recursos ou equipamentos da rede foi muito frequente também. Esta é uma ação prevista pela linha de cuidados do idoso. Segundo Veras e Oliveira (2018) as evidências apontam que a atenção ao idoso deve efetivamente ser organizada de forma integrada e coordenada em todo percurso assistencial, em lógica de rede, idealmente baseada na proposta de linhas de cuidado, com ações de educação, promoção da saúde, prevenção de doenças, cuidado precoce e reabilitação. A lógica desse tipo de modelo objetiva dirimir os problemas decorrentes da fragmentação do cuidado, melhorando os resultados das ações. O conhecimento sobre quais os recursos estão disponíveis e como se dá a adequada articulação entre eles é primordial para um emprego ideal da rede. Apesar de ainda haver entre os profissionais um parcial desconhecimento em como acessar, limitação de vagas e outras fragilidades apontadas, o uso da rede potencializou, nas narrativas, as ações de cuidado por facilitarem a redução das vulnerabilidades.

Os recursos mais lembrados pelos profissionais do CS foram o Programa Acompanhante de Idoso (PAI), o "Alimentação Sobre Rodas", o Centro Dia, a Unidade de Referência à Saúde do Idoso (URSI), o Ambulatório Médico de Especialidades Idoso (AME Idoso), a Equipe Multiprofissional de Atenção Domiciliar (EMAD), o Centro Especializado de Reabilitação (CER), o Centro de Referência de Assistência Social (CRAS), o Programa Bolsa Família e o Serviço de Assistência Social à Família (SASF). Destes, fazem parte específica da rede formal do idoso o PAI, o Centro Dia, a URSI, o AME idoso e o Alimentação sobre Rodas.

O PAI é uma equipe multiprofissional formada por um coordenador (com formação em serviço social), um médico, um enfermeiro, dois auxiliares ou técnicos de enfermagem, um agente administrativo, dez acompanhantes de idosos e um motorista. Oferece uma modalidade de cuidado domiciliar biopsicossocial destinado a idosos em situação de fragilidade clínica e vulnerabilidade social, especialmente em isolamento decorrente de insuficiência familiar ou social. São critérios para acompanhamento pelo PAl ter idade maior ou igual a 60 anos, morar na área de abrangência e apresentar pelo menos uma das seguintes características detectadas na Avaliação Multidimensional da 
Pessoa Idosa da Atenção Básica $\left(\mathrm{AMPI}-\mathrm{AB}^{40}\right)$ : dependência para realização e atividades de vida diária, diminuição da mobilidade, limitações para acesso aos serviços de saúde, risco de institucionalização, rede familiar e social insuficientes, integrar as redes formais e informais de atenção à pessoa idosa para fortalecimento de parcerias e obtenção de alternativas de atendimento das demandas. Objetiva a reabilitação, manutenção ou desenvolvimento do autocuidado, autonomia, independência, socialização e melhoria do estado de saúde (Andrade et al., 2020). A partir desses objetivos e do fato de que a incontinência familiar e o isolamento social são desafios recorrentes no cotidiano da APS, justifica-se o fato de haver com tanta frequência o encaminhamento para o PAI.

A URSI é um serviço de atenção secundária, especializado em atendimento ao idoso da sua área de abrangência e é composta por equipe multiprofissional idealmente especializada em gerontologia ou geriatria (assistente social, enfermeiro, fisioterapeuta, fonoaudiólogo, geriatra, nutricionista, psicólogo e terapeuta ocupacional). É direcionada aos idosos mais fragilizados e tem como objetivo fortalecer a permanência do idoso na comunidade pelo maior tempo e com a melhor capa cidade funcional possível.

O Centro Dia é um equipamento voltado para o acolhimento diurno de idosos com dependência parcial para atividades de vida diária, com atendimento prioritário para aqueles cujos familiares não conseguem acompanhar ao longo do dia. Também conta com equipe multidisciplinar e objetiva fortalecer vínculos, autonomia e inclusão social. No Centro dia os idosos recebem alimentação, praticam atividades de lazer, cultura e aulas variadas (conforme interesse e disponibilidade).

\footnotetext{
${ }^{40} \mathrm{~A} A M P I / A B$ é um instrumento de avaliação multidimensional utilizado na Atenção Primária de Saúde do Município de São Paulo. Sua implementação objetiva a orientação dos atendimentos, o encaminhamento para atenção especializada, a elaboração de projetos terapêuticos, a qualificação da demanda e o planejamento da gestão. Através da AMPI são avaliados parâmetros como autoavaliação da saúde, presença de doenças crônicas, internações, sentidos (visão, audição), grau de dependência para realização de atividades básicas e instrumentais de vida diária e arranjo familiar, dentre outros, por meio de 31 questões dirigidas aos idosos. Andrade SC, Marcucci RM, Faria LF, Paschoal SM, Rebustini F, Melo RC. Perfil de saúde dos idosos assistidos pelo Programa Acompanhante de Idosos na Rede de Atenção à Saúde do Município de São Paulo. Einstein (São Paulo). 2020;18:eAO5263. http://dx.doi.org/
} 10.31744/einstein_journal/2020AO5263 
O AME Idoso, referência para a população do CS é voltado para o atendimento de pessoas a partir dos 60 anos. É um recurso relativamente novo (inaugurado em junho de 2016), vinculado à Secretaria de Saúde do Estado e dotado de especialidades médicas, não médicas e alguns serviços de apoio diagnóstico.

O Programa de Segurança Alimentar Domiciliar para Idosos, denominado também de Alimentação sobre Rodas, está disponível na região central de São Paulo mediante um convênio entre a Instituição Beneficente Israelita Tem Yad e a Secretaria de Assistência e Desenvolvimento Social do Município de São Paulo. Por meio desse programa é fornecida uma refeição ao dia para idosos em situação de vulnerabilidade social e individual diretamente na sua casa, de segunda a sexta-feira. $\mathrm{O}$ acesso ao programa é feito mediante articulação com o CRAS.

O acesso aos serviços da rede é muito importante para práticas integrais de cuidado, como anteriormente indicado, especialmente por ser um movimento que propicia otimizar a interação, o enriquecimento dos horizontes das finalidades e dos processos e que amplia as possibilidades de atendimentos voltados para as questões de vulnerabilidade social, tão inerentes ao cuidado dos idosos e que, em geral causam angústia aos profissionais, como visto nas narrativas. O que é mais restrito ao campo da morfofuncionalidade, ou das questões mais inerentes à "saúde" apenas, são lidadas com mais facilidade pelos profissionais. Nos últimos anos, as políticas voltadas aos idosos foram aprimoradas, com maior estruturação de recursos existentes e criação de outros. Ainda hoje, no entanto, dado o contexto da APS, os profissionais entrevistados sugeriram possibilidades de incremento, como ampliação dos serviços já existentes (por meio de maior oferta de vagas), criação de casas de transição (semelhantes a uma instituição de longa permanência, porém com previsão de menor tempo de uso, como após uma alta hospitalar), formulação de um serviço análogo ao PAl, mas com diferentes níveis (conforme o grau de dependência de idoso, oferta de maior ou menor presença do acompanhante), treinamento para as famílias e mesmo a criação de espaços de convivência para os idosos (intergeracionais, com possibilidade de mercado de trabalho interno, mais vilas de idosos) e até a formulação de equipes que auxiliem na higienização dos 


\section{domicílios das pessoas mais velhas que possuam dificuldades para realizar essas atividades e não disponham de suporte familiar ou financeiro para arcar com tal trabalho.}

Bom, isso até tá sendo bastante discutido na prefeitura, uma das reuniões que a gente mais foi esse ano, foi pra falar de idoso. Que é meio que a bola da vez, assim, né? Principalmente, em relação aos equipamentos, os programas que vão compor a rede, né? Viu-se que a rede do município, ela é muito pequena perto da demanda que a gente tem e sabe-se que a demanda só vai aumentar, né? A população idosa só vai aumentar. Então, desses programas que a gente tem hoje, como - PAl, como o Centro Dia, o de Alimentação sobre Rodas, são programas que acrescentam muito positivamente, do meu ponto de vista. Então, ampliar esses programas seria ótimo, né? E outras coisas que surgiram, assim, na reunião, que a gente achou bem interessante, também, discutir um pouco mais. (...) Então, pensar numa equipe que possa ajudar na limpeza dos domicílios dos idosos sozinhos. Pensar em lugares que eles possam passar mais tempo, fazer mais atividades e até lugares que possam promover um mercado de trabalho interno entre eles, né? $\mathrm{E}$ até fora. Então, as vilas dos idosos, que se fala muito em outros países, também. Então, idosos, por exemplo, exengenheiros, o quanto que eles podem contribuir, formar um mercado da $3^{\text {a }}$ idade, da $4^{\text {a }}$ idade, enfim. Que eles possam ter esse retorno social, também, financeiro, né. (Fabiana, enfermeira)

Mas é uma questão cultural, você ser capaz de cuidar do outro. De vez em quando aparecem umas iniciativas de um jovem que adotou um idoso, porque o idoso tem a casa, tem isso, precisa de companhia e o jovem precisa de um lugar para estudar. Não estou dizendo que ah, é uma maravilha, é bonitinho, estou dizendo que tem duas pessoas que uma pode cuidar da outra, tem interesses distintos, mas uma pode ajudar a outra. Eu acho que a gente precisa culturalmente falando mudar essa questão da intergeracionalidade, o intergeracional. Criar atividade, criar espaços onde a criança conviva muito mais com o idoso, não é só o avô, é conviver com o idoso do outro, é trabalhar a questão do idoso na sociedade, mas isso a longo prazo (...)

Não sei se a gente investiria nisso no Brasil, nas redes de suporte, melhorar essas coisas, melhorar o PAI talvez, fosse o ideal, diversos graus de PAI talvez, junto com a EMAD, a EMAD entra, o PAI acompanha, não sei, a gente investiria nisso, isso é dispositivo familiar. Quando eu estou falando dispositivo familiar estou falando na casa da pessoa, com a família, ou não, ou teria que chegar ao ponto de pensar "olha, enquanto a gente não consegue isso, a gente pelo menos ter leito de retaguarda, ter mais ILPI, mas não definitivas". É como se eu tivesse casas transitórias de cuidado, casas transitórias para um cuidado mais qualificado.

(Débora, assistente social). 
Incrementar algumas funções do Programa de Assistência a Pessoa Idosa, do PAI. Ter a possibilidade de ter uma assistência, de ter níveis de assistência. Então ter a pessoa que é mais independente que só... Num certo sentido já tem. Mas ter alguns graus de assistência diferentes. Então, por exemplo, a pessoa que só precisa de acompanhamento nas consultas. Disso até a pessoa que precisa de visitas diárias para, não sei, ter uma supervisão no cuidado da alimentação, da higiene pessoal, da sua administração das medicações, do cuidado diário. [risada] Eu tô sonhando. (Andrea, MFC)

Além do acesso aos recursos da rede que são vinculados especificamente à saúde pública, alguns equipamentos próprios da comunidade foram elencados como a oferta de atividades para idosos do Memorial da América Latina, no Parque Água Branca, no Serviço Social do Comércio (SESC), Clube Escola Raul Tabajara, Centro Comunitário da Legião da Boa Vontade e mesmo a Educação de Jovens Adultos (EJA).

Entrevistadora: $E$ você me comentou aqui na nossa conversa, alguns mecanismos a mais, você já conhece então o CER, que você falou...

Martha: O Curumim, que tem.

Entrevistadora: O que é o Curumim?

Martha: O Curumim é um espaço que tem ali perto do Palmeiras, que ele fica... O idoso pode ir lá e passar o dia, entendeu? Tem jogo de dominó, tem...

Entrevistadora: $E$ tem vaga fácil?

Martha: É. É. Ele vai e passa o dia. Tipo uma recreação, né?

Entrevistadora: E pode chegar? Não tem número limite?

Martha: Não. Tem o SESC, que a gente indica o SESC também. De lá pra cá tem o SESC Pompeia que é bom. Hoje eu tenho paciente que vai lá fazer natação. Eu tenho uma paciente que vai todo dia almoçar lá, né? Então você tem que procurar esses alternativos que não dependem de... Mesmo na Água Branca, recomendo muito pra eles irem lá na Água Branca que tem uma turma da USP, que eles fazem ginástica, eles fazem alongamento, né? Então tem que procurar esse caminho. Aqueles que estão mais dispostos a andar, né? (Martha, ACS).

A gente tem muita coisa aqui, a gente tem o Tabajara, o parque da Água Branca, tem tanta coisa lá, tem muita coisa, na parte de artesanato, tem dança, baile, eles só não fazem bingo lá, mas o resto eles fazem de tudo. Tem três atividades, de manhã, almoço e à tarde, atividades para os idosos, tem muita coisa que você pode fazer, tem teatro, tem o Memorial da América Latina para idoso, tem muita coisa. Mas elas não vão porque não tem ninguém para acompanhar, as 
cuidadoras ficam com elas, mas algumas ficam de manhã, vão embora, vem outra à noite. (Berenice, ACS)

A possibilidade de desenvolver atividades de socialização, de estímulo cognitivo e de promoção à saúde é uma preocupação comum a vários profissionais, tanto que o impedimento da contínua oferta de algumas dessas ações dentro do centro de saúde ou mesmo na comunidade é um dos fatores sinalizados como limitantes do cuidado, com impacto inclusive na redução das oportunidades para estreitamento de vínculos. Dessarte, o retorno dessas práticas ou a inclusão de outras foram recomendadas por alguns entrevistados como melhorias que poderiam ser instituídas em prol do cuidado do idoso.

Poderia trabalhar a questão da atividade física na área, mas é um trabalho para se fazer toda semana (...) A gente tem quadra lá, tem associação, talvez um educador físico aqui na unidade seria bom. Eu sei que atividade física faz toda a diferença. Eu tenho o sonho de um dia ir lá e fazer grupo de caminhada, de zumba, só que a gente não tem perna de fazer tudo que a gente gostaria. A gente já pensou em fazer grupo com os idosos na quadra, na EPRIM [Escola Profissional de Rádio, Informação e Mobral], tem o Parque das Perdizes próximo, não é super próximo, mas é bem pertinho, dá para atravessar a avenida, o idoso quem tem maior dificuldade para andar já fica um pouquinho mais difícil, então teria que ser lá na comunidade mesmo, talvez um grupo de atividade física com um educador físico seria uma boa para ajudar as equipes para trabalhar nesse sentido, da atividade física e da dança. (Martina, enfermeira).

Sim, eu acho que na questão da academia, que alguns deles falam, eles estão procurando atividade para que eles possam não ficar em casa, na frente da televisão ou algo assim, eu acho que poderíamos oferecer caminhadas ou exercícios dentro, fora a fisio que eles têm, alguma outra atividade que eles pudessem estar vindo fazer, oferecer algo para que eles pudessem sair de casa e vir até o serviço. Antes eu sei que tinha caminhada para os idosos, mas o motivo pelo que acabou eu não sei, porque quando eu cheguei já estava meio no fim.(Carla, ACS).

Eu acho que ia ajudar bastante alguns a sair um pouco de casa, abrir a mente. Porque a gente viaja e por mais que seja cansativo a gente conhecer coisas novas, eu acho que eles iam ficar mais felizes. Mas não indo viajar com a família, eles viajando com a equipe, uma equipe que faça uma viagem, alguém de fora, acho que ia ajudar bastante. Aí na viagem ia ter roda de conversa, aquele negócio, eu acho que ia ser legal. (Laura, ACS) 
Uma das equipes realiza desde meados de 2015 um projeto denominado "Saúde no Quintal", na qual os idosos se encontram a cada 15 dias na área comum de um prédio do território. As reuniões possuem duração de aproximadamente uma hora e trinta minutos e envolve um momento inicial de prática de exercícios adequados para a idade dos participantes com materiais facilmente disponíveis no prédio (como cadeiras e cabos de vassoura) ou com o próprio corpo e depois um tempo de socialização. A atividade tem boa adesão e segundo Fernando (MFC) "é um espaço interessante para os idosos, lá tem idosos que batem carteirinha e a gente viu que teve essa melhora tanto da parte social, da parte motora também, bem bacana".

O caso a seguir, narrado por Andrea, apresenta alguns recursos utilizados em comum com o relato anterior (como o trabalho em equipe e o uso da rede de cuidado do idoso), mas traz diferentes caminhos que também foram acessados em outras abordagens e serão destacados a seguir.

Consigo lembrar um de sucesso. Meio que, depois, o paciente faleceu. Assim, era um paciente sozinho, idoso, com grau de depressão importante e era idoso 70, anos, assim. Uma pessoa aparentemente muito funcional, que vinha pouco ao serviço de saúde. Veio mais com queixa de perda de autonomia, porque não conseguia trabalhar. Uma pessoa completamente sozinha, sem nenhum suporte familiar e com um grau de desnutrição importante, uma perda de peso muito importante que excluindo todas as outras possibilidades, realmente era uma falta de alimentação. $E$ a gente conseguiu $e$ foi bem multidisciplinar. Porque além dos ajustes dos tratamentos que foram... Mais ou menos, porque de comorbidade clínica, mesmo, tinha uma hipertensão. Mas tinha um certo grau de, parecia uma aparente inicial de demência, que com antidepressivo melhorou. E a gente pediu o acompanhamento do PAI, que também ajudou muito. Ele se sentiu muito melhor, ele se sentiu mais considerado. Acho que foi uma das falas dele. E ele voltou, ganhou peso, tava muito mais positivo. Era extremamente resistente. $\mathrm{Na}$ verdade, ele tinha acessado aqui, só porque ele era pintor e não conseguia mais. Tinha gatilho, não conseguia mais pintar. Não tinha segurança no equilíbrio pra subir nas alturas. Ele só queria resolver esse problema. $\mathrm{E}$ a aderência dele foi melhorando aqui. E a sua situação também. Ele se sentiu mais acolhido. Às vezes, até demais, né? Vem pedindo coisas que a gente não tem. [risada] Não tem como. Mas mesmo assim, eu achei que foi um sucesso. A gente conseguiu Alimentação Sobre Rodas pra ele. Que infelizmente não conseguiu chegar a tempo. Ele faleceu foi, nem 
sei como. Foi uma morte súbita. Foi em casa, sozinho. Mas se ativou uma rede social ao redor... (Andrea, MFC).

A partir do entendimento sobre quem é a pessoa com a qual e para qual se voltavam as ações, sobre seu projeto de felicidade, do fortalecimento de vínculo, acolhimento e acesso a recursos da rede, sem prescindir da técnica, e por meio da mobilização de apoio multidisciplinar que se deu o Cuidar no caso relatado por Andrea.

O voltar-se à presença do outro, parte da premissa de se superar a restrição de um trabalho fundamentado exclusivamente na racionalidade biomédica. Embora a tecnologia tenha levado a inegáveis avanços no entendimento e terapêutica para diversas demandas no plano da corporeidade, a perspectiva da presença do outro (sujeito) guarda importante interesse para 0 Cuidar (Ayres, 2004a). Para isso, o uso de recursos das denominadas tecnologias leves (Merhy, 2000) ganha espaço especial na relação terapêutica. Ouvir, ver e tocar mais e diversamente; procurar entender a percepção pessoal do idoso, sua real necessidade, enxergar de modo individual e integral (não como a expressão de uma patologia) são apontados como recursos importantes e utilizados por outros profissionais.

Eu sei que as pessoas não são iguais, mas eu gosto muito de ouvir o paciente. Eu gosto de ouvir, deixar ele falar. Depois eu penso, eu faço a minha conclusão. Porque, muitas vezes, só no falar, eles já têm uma melhora, eles já têm... Eles já ficam aliviados: "Nossa, ela me ouviu." Eu ouço muito isso. "Nossa, você me ouviu. Você deixou eu falar." Então penso nisso. Eu acho que isso é uma coisa que poderia melhorar, independente do tempo, independente da demanda, acho que dá pra ouvir um pouco mais. (Dulce, técnica de enfermagem).

Uma mensagem que carrego comigo é compreender para atender. Primeiro eu preciso compreender o que o meu paciente necessita. $O$ que ele de fato veio fazer aqui? Para eu poder atendê-lo com qualidade. Então precisa ter uma escuta, acho que falta isso, acho que em quase todo lugar falta essa escuta. Às vezes o paciente vem tão agitado e não é nada, ele não quer nada, ele só quer que alguém escute, ou às vezes é uma coisa tão supérflua, e para ele é um transtorno, que se você só escutar o que ele está falando você vai compreender o que ele quer e vai atendê-lo de uma forma melhor (Diego, técnico de enfermagem). 
Mas, assim, eu sei respeitar você e comecei a ver você de um modo diferente. Você, pra mim, não é uma pessoa. Você não é só mais um. Você é um, no meio de todos. Isso eu aprendi aqui. Olhar não só, só pessoas, doença. Comecei a ver pessoas já num todo, sabe? Eu aprendi muito isso aqui. (Rafael, ACS).

Então eu vi, assim, que eles necessitam de uma palavra, de um apoio, de um abraço. Eu cheguei na casa dela. Aí eu abracei ela: "Bom dia. Tudo bem?" E falei assim: "Que Deus abençoe." Ela falou assim: "Meu Deus, eu tava precisando disso. De um abraço, de um carinho, de uma palavra... Deus é maravilhoso, porque eu tava tão fechadinha no meu mundo aqui, conversando com os meus santinhos, a minha Nossa Senhora e, de repente, aparece uma pessoa alegre, divertida"... (Soraia, ACS)

Andrea: $\mathrm{Na}$ pessoa jovem a gente investe mais na educação, na sensibilização, então na melhora progressiva da aderência, nesse sentido, aumentando a conscientização do paciente. A pessoa idosa, eu acho que é mais um processo, não digo oposto, mas diferente, de entender qual que é a própria percepção, a percepção da própria saúde e a percepção do ser cuidado. Então, tento respeitar isso dentro do possível.

Entrevistadora: Como que seria isso de entender a percepção do ser cuidado?

Andrea: Uma é essa que te falei, a pessoa a vida inteira, tem alguns pacientes idosos que toda consulta me pedem se pode tirar alguma medicação. [risada] "Porque tô tomando muito comprimido." Então, vê se dá, se tem a possibilidade de fazer alguma associação, né? Pra não reduzir, mas tomar um comprimido a menos. Ou, realmente, tem algumas coisas que dá pra retirar. Outras coisas que dá pra melhorar a qualidade de vida, mesmo que não vai afetar a quantidade de vida ou a... Acho que na $3^{\text {a }}$ idade, na pessoa idosa acaba sendo mais importante, às vezes, do que pensar em viver três anos a mais. Outros é ao contrário, a percepção do ser cuidado é a medicação. Então tem que dar alguma coisa. (Andrea, MFC)

A demanda para os serviços de saúde, muitas vezes, esconde uma demanda muito mais profunda embaixo, né? Que é uma demanda de atenção, de cuidado da família, não do serviço de saúde. Mas acaba jogando pros serviços de saúde, porque acaba se manifestando com queixas de saúde. Que não são realmente... são demandas de atenção, pessoa que tá ficando muito sozinha, que tá se sentindo negligenciada pela família. (Andrea, MFC).

Ao serem interrogados sobre sugestões quanto ao que consideram como pontos em que se pode melhorar de forma geral na saúde para melhor 
atendimento ao idoso, alguns profissionais salientaram justamente a questão da escuta.

\begin{abstract}
Eu acho que precisaria ter um olhar melhor, ouvir mais o paciente. Mas ouvir com mais atenção. Eu sei que é um pouco, às vezes, difícil por conta de muita demanda. Mas eu sinto falta de que os profissionais, eles ouçam mais o paciente. Presta mais atenção naquilo que 0 paciente tá levando. Porque, às vezes, o paciente tá fazendo uma queixa e muitas vezes o profissional pode tá ouvindo e já pensando "Ah, deve ser uma cefaleia" (...) se depender realmente de uma melhoria, eu acho que esse lado que eu te falei, assim, de ouvir mais, de buscar mais uma, como é que eu posso dizer? Eu acho que ouvir. Eu acho que ouvir e prestar atenção naquilo. "Ah, eu tava com uma queixa, mas o médico não prestou muita atenção, cuidou da outra queixa." Então eu ouço muito isso. Eu não sei se os profissionais, se tá tendo alguma formação de profissionais sem muita, sem muito amor na profissão ou não sei. Eu não sei. Não tenho uma resposta exata pra te dizer. Porque a demanda, ela é grande. Mas a partir do momento que aquele paciente tá dentro do consultório é a demanda daquele paciente. É ouvir aquele paciente. Seja, seja corrida ou não a consulta, mas tomar bastante cuidado com isso. (Dulce, técnica de enfermagem).
\end{abstract}

Tem, a pessoa tem que saber escutar. O que está perdendo a vivência das pessoas, a pessoa quer fazer tudo correndo, não escuta as pessoas, acho que a gente tem que escutar os mais velhos, não é tudo corrido, tudo rápido, vamos logo. (Berenice, ACS).

De fato, Ayres (2009b) aponta o fato de que as narrativas, que são tão imprescindíveis para a orientação do raciocínio diagnóstico e terapêutico, foram paulatinamente sendo substituído pelas tecnologias, que possuem um potencial redutor, perdendo-se a totalidade. A medicina centrada na pessoa (Stewart et al., 2017) também traz a importância da escuta, do ouvir mais e melhor, como o ponto inicial do método clínico que propõe, como primeiro passo, explorar a saúde, a doença e a experiência com a doença da pessoa que procura 0 atendimento. Essa busca requer ouvir sobre quatro dimensões da experiência da doença que são: sentimentos, ideias sobre o que está errado, efeitos causados pela condição na vida e as expectativas em relação àquele encontro terapêutico. Essa prática requer uma busca ativa por entrar no mundo da vida da pessoa para compreensão das suas percepções sobre saúde (seu significado, 
aspirações e metas de vida - que remete de certa forma ao projeto de felicidade) e sua experiência ímpar com a doença.

No caso de Andrea, o acesso ao projeto de felicidade do idoso e o olhar para ele na totalidade fizeram com que ele se sentisse "considerado" ou visto. $\mathrm{O}$ projeto de felicidade de uma pessoa é o que ela entende, concebe, como uma vida bem sucedida e que a move ou a orienta em seus projetos existenciais (Ayres, 2004a). Ayres também sustenta

\begin{abstract}
A ideia do projeto de felicidade como uma espécie de horizonte normativo implicado na noção de cuidado. Isto é, o projeto de felicidade é a referência que nos permite compreender o que as pessoas estão buscando em nossas capacidades instrumentais e, no mesmo movimento, permite às pessoas compreenderem 0 que temos efetivamente para oferecer a elas com nossas tecnologias (AYRES, 2009b, p. 18).
\end{abstract}

O horizonte do projeto de felicidade, então, orienta usuário e profissionais num movimento em prol da realização das escolhas mais potentes e indicadas a fim de se atingir os maiores benefícios no cuidado.

O ouvir diversamente, também envolve a busca pela compreensão de quais são as prioridades da pessoa que procura 0 atendimento e suas dificuldades. Ouvir e responder primeiro a uma demanda que parte do usuário (e depois aliar às demandas que são identificadas pelo profissional), auxiliar o idoso na execução do seu autocuidado considerando suas capacidades e considerar a execução de formas alternativas de se atingir o sucesso prático são outras estratégias utilizadas pelos entrevistados.

Por isso é importante a gente sempre avaliar a situação de uma consulta para outra, se seguiu as orientações direitinho ou não. Se não seguiu, por quê, e tentar encontrar junto com o paciente o porquê e a melhor forma de concretizar. (Fernando, MFC).

Antes, me incomodava bastante. Tipo assim, eu achava que tinha que ser do meu jeito, sabe? Tipo: "Vamos fazer assim, porque assim é melhor pra você." E aí com o tempo, né, você vai aprendendo, vai vendo e observando e vendo, né? Outras pessoas e aí, hoje eu falo assim, hoje eu escuto muito o que o paciente deseja. E eu tento focar naquilo que o paciente deseja. Tem um paciente meu que ele fala assim "Olha, eu não me importo que eu não escuto, eu me importo com 
a minha visão." Então eu falei: "Então eu vou conversar com a médica, a gente vai procurar um oftalmo pra senhora de caráter de urgência e aí a audição a gente vê depois." Mas aqui eu falo tem problema de audição, também, além da visão, tal, não sei o que. Então, assim, agora eu consigo filtrar. Tipo assim, senão era: "Não. Mas, olha, a gente tem que já marcar o otorrino, marcar oftalmo, já marcar um cárdio porque ele reclamou que há três anos atrás tinha problema de coração." Então, assim, aqueles negócios, vamos fazer as prioridades. Eu comecei a usar isso. (Diego, técnico de enfermagem).

Tem uma paciente até agora que é analfabeta, não sabe ler nem escrever nada. Aí acompanhei ela, até levei para fazer exames e várias vezes eu acompanhei. Mas eu falei para ela "fala para a sua amiga..." e ela tem filhas e morava com uma neta, mas a neta na época não se preocupava... agora que eu conversei com a neta "agora que você é casada pelo menos tira um tempinho que ela vai ficar muito sozinha e vem assim pelo menos no final de semana para ver", e ela marca do jeito dela as consultas e como deve tomar o remédio primeiro, vou tomar direitinho, aí eu fiz assim em uma cartolina, fizemos com uma auxiliar, como deveria tomar à noite, fizemos uns desenhos, mas ela não conseguia assim. Aí ela falou "posso fazer do meu jeito?", aí eu ajudei a ter umas caixinhas, aí ela pinta com preto à noite e quando é de manhã, amarelo, e na hora do almoço quando tem que tomar ela coloca uma banana, aí sempre eu vou ver se está tomando direitinho.(Olívia, ACS).

É. Eu acho que eu transmito um pouco. É, se não tem o um, você vai nos dois. Você tem que ter sempre um plano alternativo, né? (...), mas que nem, você sair, vamos supor, fazer uma caminhada. É uma coisa diferente você, vamos supor, ele vai ao banco e sofre um assalto. Além de ter todos os riscos, ele vai ficar sem dinheiro. Mas é diferente de eu estimular ele fazer uma caminhada. Porque ele não tá mexendo com dinheiro, né? Ele tá ali por perto. Você entendeu meu ponto de vista? (Martha, ACS)

A perspectiva de um plano conciliador também é citada como opção para lidar com dificuldades, sendo que esta nova pactuação nem sempre advém de necessidades exclusivas do idoso, mas ao se considerar todos os envolvidos no processo cuidado-saúde-doença, como o cuidador informal. Essa pactuação é considerada no terceiro passo da Medicina Centrada na Pessoa (Stewart et al., 2017) em que se prevê a elaboração de um plano conjunto de manejo. A partir desse passo, são elencados os problemas e prioridades (identificados por ambos os sujeitos participantes do encontro terapêutico), quais as metas do tratamento (que na perspectiva do Cuidado devem considerar o Projeto de 
Felicidade) e a definição dos papéis da pessoa e do médico. No caso abaixo, ressalta-se esse acolhimento das demandas partidas do cuidador e a inclusão de papéis do mesmo.

Daniela: Principalmente se o cuidador é cônjuge ou filhos de primeiro grau, é muito comum que se tenha essa discrepância de percepção, por isso que é importante ter a visão dos dois. O idoso traz algumas questões... é muito comum, por exemplo, o idoso quer ficar na dele, quer ficar em casa, quietinho, no canto, sozinho, então ele vem falando que está tudo ótimo, tudo bem, e vem o filho, o cuidador, esposo, sai briga na consulta, "não, porque ele não faz nada, só quer saber de assistir TV o dia inteiro, não faz nada", e às vezes a gente tem que conciliar as percepções.

Entrevistadora: Como você faz isso?

Daniela: A gente compactua ali. A gente tenta achar uma questão intermediária porque é muito difícil você ser cuidador, demanda uma energia de vida brutal. Você precisa valorizar esse indivíduo. Não adianta dar só razão para o paciente, falar assim "não, ele tem autonomia para decidir o que ele quer e a gente vai respeitar isso", acabou, ali você acabou com o cuidador, porque ele deu todo o gás, não dorme, fica doente junto e não tem o mínimo de responsabilidade, de poder de atuação, então a gente entra num consenso, "está ruim como está, então vamos fazer assim, ela está preocupada com o senhor, você vê que cada um está falando uma questão diferente, mas isso significa que vocês estão preocupados um com o outro e o que a gente tem que chegar aqui é num consenso do que é melhor, o senhor sabe que o melhor, do ponto de vista médico, é que o senhor se exercite mais, mas eu também entendo que não precisa correr de um lado para o outro o tempo todo, a expectativa dela é muito mais alta do que eu sei que o senhor vai conseguir. Então, se a gente começar aos pouquinhos? Começar fazendo caminhada no jardim de cinco metros todo dia, para ir ampliando isso, ou dando responsabilidade", muitas vezes tem conflito de percepção porque o idoso não faz nada, mas ele não é responsável por nada, que estímulo você tem se não tem responsabilidade nenhuma na sua vida? É esperado que ele não vá querer fazer nada, lá no canto, sozinho. A gente tenta atribuir responsabilidades, tem paciente "ah, não consigo ficar de pé", vai dobrar pano, passar sentado, enfim, a gente começa a dar responsabilidade na casa e tenta compartilhar o cuidado porque muito conflito é estresse do cuidador. A gente distribuindo o cuidado com os outros e vai chegando em percepções um pouco mais equivalentes. É muito estratégia de comunicação isso que a gente faz de tentando amenizar e chegar num ponto que nunca é o ideal, do ponto e vista médico, nunca é o ideal, mas é o que a gente consegue fazer. (Daniela, geriatra) 
A ideia de responsabilização mútua, partilhada pela MCP como exposto acima também aparece nesse relato. Trata, portanto, da união de pontos de vista possivelmente divergentes em um plano de ação comum (Stewart et al, 2017). O compartilhamento das ações propostas para a produção de cuidado tem sua efetividade ou resolutividade relacionada a quão potentes são os encontros e quão sensíveis estão os profissionais aos projetos de felicidade dos envolvidos no cuidado (Ayres, 2009b). Vale lembrar que em todo momento pode-se (e deve-se, no plano do Cuidado) privilegiar esses encontros:

\begin{abstract}
Quando nos damos conta da ipseidade de nossas identidades subjetivas, isto é, do caráter substantivamente intersubjetivo, relacional da construção e expressão de nossas identidades, então somos levados a pensar de forma mais consequente a qualidade dos encontros que estamos efetivamente promovendo nos espaços de atenção à saúde. As condições em que promovemos os encontros entre profissionais e destinatários das ações de saúde, já desde o plano macro em que se formulam políticas e modelos de atenção à saúde até o plano micro dos encontros interpessoais, nos espaços assistenciais, são diretamente responsáveis pela expressão de nossas subjetividades. Portanto, não podemos pensar em vínculo como escolha individual, seja de profissionais ou de populações e indivíduos usuários de serviços. Precisamos pensar em vínculo como a construção de oportunidades de encontros menos ou mais capazes de favorecer intersubjetividades mais ricas, plurais e produtoras de compartilhamentos (AYRES, 2009b, p. 19-20).
\end{abstract}

Por fim, o terceiro caso, narrado por Berenice evidencia ainda outros recursos utilizados pela equipe para o cuidado do idoso.

Berenice: Tenho outra senhora, dona E., ela é argentina, está há bastante tempo no Brasil, perdeu o marido e está perdida, não sabe o que fazer e ela é nova, tem 75 anos... eu já acho nova, mas é uma idosa de 75 anos, mas tem dificuldade, por ela ter dinheiro, mas tem dificuldade, e a família não quer saber dela, nem os netos, não querem saber dela. Mas os vizinhos contam que quando ela era mais jovem ela era muito ruim, então ela está colhendo o que plantou.(...)

Entrevistadora: Quais os desafios que você vê no cuidado dela?

Berenice: Tudo. Cuidado de alimentação, higiene, cuidado dela ficar sozinha, porque ela não tem cuidadora, ela não aceita qualquer pessoa, ela é muito desconfiada, ela precisa de tudo. Ela é visita domiciliar do doutor Fernando, mas toda vez que ele vai, ela atende na portaria do prédio. Já foi assistente social, agora foi o promotor do idoso, ela não atendeu, a Débora está tentando interditar ela. Estava falando para a Débora, eu acho que se interditar vai ser muito triste 
porque ela vai morrer muito rápido, porque bem ou mal ela está acostumada a sair em volta do prédio, andar naquela condição, o porteiro buscar almoço para ela, acho que se por ela num lugar ela vai acabar morrendo.

Entrevistadora: Mas ela não está lúcida?

Berenice: Tem vez que ela fica lúcida, tem vez que não. Eles falam que não, para mim, eu acho que está, mas eu não sou médica. Eu acho que ela é muito sozinha, por isso que ela é assim. Só que os netos não têm paciência, um mora em Portugal e o outro mora no Rio de Janeiro, só que falou assim que quando ela era mais jovem ela era muito ruim com a filha e com os netos...

Entrevistadora: A filha já faleceu?

Berenice: Já. E aí ninguém aceita, ninguém conversa com ela. Se você for no prédio todo mundo gosta dela, todo mundo tenta ajudar ela, mas o medo é dela sair e não saber voltar, sair e esquecer de voltar para casa.

Entrevistadora: E o que vocês já tentaram fazer? Quando você visitou ela e se deu conta dessa situação, foi você que viu direto, o porteiro que falou, algum vizinho, como começou essa história?

Berenice: Foi assim, primeiro começou com o seu F. que é um argentino, marido dela, ela tinha problema de pressão alta e não se cuidava. Aí eu fiz o cadastro. Desconfiado, também lá não deixou a gente subir, ele falava muito, assim, argentino, e desconfiado, eu falei "seu F., vamos cuidar da saúde do senhor, da dona E., aí ele concordou, fez o cadastro, só que passava mal e corria para o prontosocorro...

Entrevistadora: É mais perto?

Berenice: É. E aí os vizinhos falaram "Berenice, você fez o cadastro dele?", falei "fiz", eu ia até pedir para o doutor Fernando visitar os dois, os dois ter visita domiciliar, porque ele tinha uma deficiência na perna, ele andava com a perna mancando. Tanto que quando ele passou mal eu que socorri, eu que levei ele para a Santa Casa, internei, ele e a dona E., mas como ela estava um pouquinho fora da casinha, não estava entendendo o que estava acontecendo, aí eu falei com a assistente social, liguei para a Fabiana, para o doutor Fernando se podia fazer as coisas, doutor Fernando falou "pode ", aí eu fiz, internei ele, aí depois veio a dona N. e o porteiro, aí eu falei para a assistente social para passar a responsabilidade para eles, como eles são do prédio porque eu não podia ficar com essa responsabilidade. Aí ficaram o porteiro e a vizinha ficou responsável por ele. Aí um dia antes do seu F. morrer nós fomos lá e ele estava bem machucado porque ele se batia muito, aí amarram ele, ela foi junto, ela chorava muito, queria que o seu F. voltasse para casa, a gente explicou que ele não podia voltar, aí ele reconheceu ela, conversou bem com ela. Aí quando foi de tardinha eu vim embora, ficou o porteiro, a vizinha e a dona E., aí quando era umas $18 \mathrm{~h}$ e pouco, eu cheguei em casa e o porteiro me ligou falando que ele tinha acabado de morrer. Aí o porteiro e a dona N., que é a vizinha, correram com as papeladas. Aí ligou para o neto, ele já tinha embarcado para Portugal, aí veio a neta, que falou que não queria saber, deu o dinheiro, acertou as papeladas com a dona N. que fez o enterro e falou que não queria saber da dona $E$. não, que era 
para a gente se virar, aqui o posto ou a dona N. e o porteiro. Aí eu passei tudo para a Débora que começou a seguir o caso, aí passou para a promotoria, agora estão vendo se conseguem internar ela em algum lugar. (Berenice, ACS).

O relato acima exemplifica uma situação muito delicada no cuidado do idoso na atenção primária: a incontinência familiar ou isolamento social em uma situação na qual o idoso apresenta declínio da capacidade funcional ou condição de dependência. Os recursos utilizados, como a judicialização, a procura por familiares e a criação de uma rede informal (como com vizinhos e porteiro) são utilizados em outros casos semelhantes.

A instrumentalização de quem está em volta, ou a tal criação de uma rede informal de apoio, conforme observação no trabalho de campo, se deu de forma a orientar vizinhos, porteiros, comerciantes próximos quanto a como proceder em casos de situações de emergência que envolvam esse idoso, incluindo indicação dos contatos de emergência, auxílio para receber a alimentação que chega pelo programa Alimentação sobre Rodas, por exemplo, ou orientar sobre a disponibilidade dos recursos na UBS. Do ponto de vista dos profissionais, normalmente esse suporte fica aquém das necessidades, contudo pode ser uma ponte enquanto outras medidas são tomadas ou mesmo configura-se como uma possibilidade de conciliação entre desejos e capacidades de idosos e familiares.

Por exemplo, a visita domiciliar continua mesmo que ela diga que a gente não apareça lá? Continua. A agente comunitária bate, ou se é um caso complexo eu vou visitar "olha, estava passando na rua e vim te visitar, eu estava aqui no seu vizinho, vamos conversar?", "não", "olha, eu estou te esperando lá, hein". Então, assim, a gente força, não de forçar, de vez em quando faz algumas visitas. A gente não faz atividades aqui dentro? Não é bingo, mas é dômbola, com chás, de vez em quando tem uns eventos que incluem idoso, jogamos o convite embaixo da porta dela. Que que a gente também faz? Chegamos nos vizinhos e falamos "convence ela de vir aqui com você, fala para ela vir te acompanhar no atendimento par ela ver como é que é, sem cobrança, nós não vamos nem olhar para ela, mas convida ela para vir nessa atividade". Por isso que é bom se certificar o que esse idoso tem de suporte, porque nosso trabalho fica em dar suporte e instrumentalizar quem está em volta quando a pessoa nega. (Débora, assistente social). 
As questões que envolvem família e acionamento do Ministério Público em geral possuem uma tênue relação, já que o principal motivo para 0 encaminhamento para a promotoria é quando não se tem o suporte familiar ou as situações denominadas de negligência. Em geral, a equipe investe antes em outras alternativas e, na falha delas, segue com a judicialização. Uma dessas alternativas que precedem o caminho legal é a reunião familiar. Segundo os profissionais, procura-se nas reuniões explicar o motivo pelo qual o idoso precisa de auxílio (já que em algumas situações a família desconhece a necessidade por opção do idoso que, nas palavras deles, não quer "ser um peso"), entender o lado da família e mesmo auxiliar no fortalecimento dos vínculos e tratar as relações. Após esses encontros, idealmente abre-se a possibilidade de um plano conciliador, o que não significa que necessariamente satisfaça à expectativa de todos (incluindo os profissionais de saúde na equação).

Fernando: A gente faz o caminho através da assistente social, ela convoca o filho e aí a gente tem uma conversa em conjunto com a família. $O$ idoso normalmente não participa e a gente explica a gravidade da situação, toda a necessidade do tratamento, do acompanhamento que ele precisa (...)

Entrevistadora: $E$ por que que o idoso não participa dessa reunião?

Fernando: Ele pode participar, mas normalmente é porque às vezes o idoso não tem a noção da complexidade que é o tratamento, o acompanhamento, e às vezes uma das dificuldades do idoso aceitar é isso, às vezes ele não quer se sentir um peso para a família, então é mais por isso que a gente separa essa primeira conversa. Depois a conversa é em conjunto, lógico, mas essa primeira conversa da importância do tratamento, do acompanhamento é separado por isso, às vezes o idoso acha que "não, eu vou dar muito trabalho", é sempre essa mesma história, "eu não quero que venha porque eu vou dar trabalho, não quero dar trabalho", é sempre essa fala. Mais por isso, para não ter esse conflito, mas depois normalmente que a gente chega em um acordo a conversa é com todos, inclusive com o idoso para chegar num acordo mútuo. (Fernando, MFC).

Mas para nós e para a equipe é muito importante a reunião familiar para a gente conhecer as pessoas, saber o que elas falam, qual a relação de uma com a outra, então às vezes nas reuniões familiares é um quebra-pau. E a gente começa a ver então como a família funciona lá quando a gente não está. Então casos que a gente pegou aqui, a reunião familiar era muito importante também para nos trazer elementos como a família se vê, como a família entende o cuidado, 
como ela se dá, como se dá as relações delas. (Débora, assistente social).

A partir da constatação da grande demanda por encontros familiares e das necessidades inerentes ao cuidado domiciliar é apontada a proposta de melhoria do cuidado do idoso por meio de realização de grupos de cuidadores e capacitação das famílias.

\begin{abstract}
Chegou o momento que eu acho que talvez é importante, por exemplo, grupo de cuidador, é um momento em que você pode discutir isso com a família, com o cuidador, fazer mais reuniões familiares aqui. Só eu não dou conta, exatamente que seria o ideal para o grupo porque a gente trabalharia rede de cuidador, trabalharia a rede de suporte, tentaria trabalhar outras possibilidades que não o idoso, porque a gente fica o tempo todo insistindo no idoso. Às vezes não, às vezes a gente pode trabalhar de outra forma que também vai ser benéfico para 0 idoso. (Débora, assistente social)
\end{abstract}

A construção de uma situação mediadora também pode trazer boas vivências para a família - bilateralmente, para o cuidador e o sujeito cuidadocomo no caso relatado abaixo. Fato que pode ser mais facilmente oportunizado por características inerentes ao trabalho na ESF: conhecimento e acesso a outros membros da família.

\begin{abstract}
Ela perdeu o pai, ela perdeu a mãe. O pai se suicidou. A avó dela morreu e a tia-avó que cuidou dela e do irmão. E ela tava perdida na vida. Quando nós começamos a cuidar da tia-avó dela, ela tava com problema, porque ela tinha operado o fêmur. Então a gente começou ir. Mas nessas alturas a gente nem conhecia a R. A R., ela vivia perdida no mundo. Quando eu conheci a R., que foi que a gente começou a conversar, começou a falar dos cuidados da tia dela, tal. E foi esse o plano B, que ela cuidou da tia-avó dela até o fim, entendeu? Hoje a gente tem a maior amizade. Porque ela acha que a gente fez muito pela avó dela e eu acho que não. Acho que quem fez foi ela. (Martha, ACS).
\end{abstract}

A medida final tomada nos casos em que não se consegue o suporte social ou familiar, ou quando há situação de violência é a judicialização.

Isso é o que eu vejo assim dos casos mais complexos que eu tenho, esses são os mais complicados, porque quando não tem rede de 
suporte familiar a gente não sabe o que fazer, muitas vezes a gente constrói. Teve um caso belíssimo que a $\mathrm{D}$. fez um trabalho muito bom com a rede da igreja, ela era tão próxima da igreja, ela dedicou tantos anos para a igreja que quem se tornou curador dela foi o padre. Mas para a gente chegar nisso, você entende o trabalho que teve nas reuniões, Ministério Público, envolver todo mundo, mas não sei se a sociedade brasileira está se tornando uma sociedade tão solidária para a gente conseguir fomentar tantas redes não familiares, eu não sei. (Débora, assistente social).

A gente teve um caso bem grave de dois idosos sozinhos, uma filha fisioterapeuta. Quer dizer, você vê que é uma pessoa que tem nível universitário. Não é qualquer né? Um neto, também, já adulto. $O$ senhorzinho acamado, com prótese de quadril. A idosa, ela tinha uma suspeita de ser histriônica, mas não era um caso fechado. Mas tinha algum, algum diagnóstico psiquiátrico. Os dois largados, abandonados. Aí morreu, a filha levou, internou na outra cidade, lá, outro bairro. Saiu da área, a gente não tem nem mais notícia. Mas, assim, foi pro Ministério Público várias vezes. Relatório e relatório. O PAl fez relatório. Eu fiz relatório. A Andrea fez relatório. A outra médica que ficou no lugar da Andrea fez relatório. Não resolve. Vai, bate lá e volta. A gente tem bastante caso assim. (Carolina, enfermeira)

O arcabouço jurídico brasileiro estabelece que a família tem a função de proteção de seus membros, especialmente dos mais frágeis. Na Constituição Federal de 1988 ela é designada como base fundamental da sociedade e fomentadora da dignidade dos seus membros. O Estatuto do Idoso de 1992 apresenta a família como a principal responsável pelo apoio aos idosos e dependentes, ainda que o compromisso da sociedade e do poder público sejam reconhecidos. O Código Civil de 2002 também permite a inferência de que a família tem a função de proteger os seus membros. A lei, então, está de acordo com certo consenso moral que norteia 0 papel da família. De fato, o descumprimento desse papel incorre no motivo mais frequente de denúncias ao ministério público naquilo que é pertinente ao idoso: a insuficiência do cuidado familiar ou da negligência com o idoso (Lemos, 2013). De modo geral, essas denúncias são resolvidas dentro do próprio âmbito do Ministério Público Estadual, sem necessidade de encaminhamento para a Justiça Federal. Em estudo conduzido por Lemos (2013), em que foram avaliados processos conduzidos pelo Ministério Público, a maior parte das resoluções ou pactuações partiram não de uma apropriação de responsabilidades pela política, mas de 
nova divisão dos papéis para a família. Esse desfecho dialoga com o conceito de "reprivatização da velhice", apresentado por Debert (1999). Historicamente o cuidado do idoso já foi uma pauta iminentemente familiar (esfera privada), passando a ser apontada em meados do século XX também como uma agenda social (esfera pública) e atualmente realocada para dentro da responsabilidade individual. Nela entende-se que os problemas vivenciados pelos idosos se transformam em responsabilidades dos próprios indivíduos, num fenômeno de culpabilização. Esse movimento permite, então, que a velhice seja relativizada no campo das preocupações sociais. Nesses moldes atuais, como no Estatuto do Idoso, a culpabilização da família desvia de certa forma do que deveria ser o ponto crucial: políticas consistentes e concretas de apoio ao idoso frágil, dependente ou em situação de maior vulnerabilidade social (Lemos, 2013). A vulnerabilidade programática, tão destacada nos desafios encontrados pelas equipes para a assistência ao idoso, surge aqui novamente.

Não que a família deva ser isenta de qualquer diálogo ou tentativa de pactuação. Pelo contrário, como vimos nos relatos, envolver a família é essencial e em muitas vezes suficiente, já que em algumas situações os familiares sequer sabiam das necessidades daquele idoso. Ademais, a orientação familiar é um dos princípios da Atenção Primária no Brasil, bem como uma prerrogativa para atuação do MFC. Mas é de se considerar que as carências familiares (afetivas, materiais), a limitação de tempo (muitas vezes por jornadas excessivas de trabalho), o desconhecimento sobre as especificidades do envelhecimento, bem como as transformações ocorridas no núcleo familiar (como redução do número de filhos) impõem dúvidas quanto à possibilidade de eficácia dessa rede de proteção a longo prazo (Lemos, 2013; Duarte et al., 2010). Além disso, "a família do idoso é uma estrutura elaborada por si mesma, sendo, de alguma maneira, responsável pelo tipo de dinâmica a que pertence" (Duarte et al., 2010, p. 46). Ou seja, o comportamento dos filhos ou dos familiares no presente responde a estruturas sistêmicas que foram elaboradas pelos próprios idosos, ou, em outras palavras, de como se estabeleceu o vínculo ao longo da vida. As questões econômicas também são importantes limitadores (ou facilitadores) da continência familiar. Considerar todos esses fatores em conjunto faz do encontro ou reunião familiar um ponto importante do cuidado. 
Entender essas relações permite um planejamento conjunto daquilo que é possível ou passível de execução para cada um, a se considerar os laços e as potencialidades individual, familiar, política e do sistema de saúde. O ponto central da questão da autonomia desse idoso, da expressão de seu desejo, também é aqui mais uma vez tensionado. Entender essas histórias profundamente faz parte da construção das possibilidades efetivas de se viver o projeto de felicidade viável. É dentro dessas possibilidades que surge, por exemplo, a opção de acionamento da rede que o idoso construiu ao longo da vida, rede essa entendida como conjunto de pessoas com as quais se relaciona, podendo ser por amizade ou camaradagem, por exemplo, e que se tenha vínculo de confiança (Lemos, 2013). Este foi um dos recursos utilizados no caso de Berenice, por exemplo, por meio do acionamento da vizinha e do porteiro.

Por fim, como a demanda de cuidado não é apenas material, mas, em geral também de afeto e amor, as soluções que levam o fim regido pelas leis nem sempre irão dar conta de todas as necessidades. A lei estabelece a obrigatoriedade do cuidado por parte da família dentro das suas condições. Obrigar a realização com boa vontade e afeto foge ao escopo do Direito (LEMOS, 2013), como observado na fala de Débora.

Pela lei, a família de algum modo vai ter que prover o cuidado, nem que seja por terceiros ou dar acesso a esse cuidado, mas não precisa ver, não precisa amar, não precisa dar atenção (...) Às vezes o ministério público faz muito essa discussão com a gente, que 0 ministério ele garante o que está na lei, que a família tem que prover o acesso e o cuidado dessa forma, mas o cuidado não necessariamente significa amor e afeto. Com essas famílias fica até mais claro quando eles colocam em cima da mesa para a gente que é o seguinte, "você não vai fazer eu cuidar de um cara que me violentou a vida inteira", "não, não vou mesmo, e o máximo que eu puder fazer para te ajudar a não conviver com ele eu vou fazer, mas é que existe uma coisa que a gente vai ter que de alguma forma organizar o cuidado dessa pessoa, porque ela não pode morrer por negligência, abandono, fome", então eu preciso que a família entenda que em certo momento eles são responsáveis sim pelo cuidado.(Débora, assistente social).

Diante do exposto, depreende-se a ideia de que a autonomia que se evoca no cuidado do idoso não deve ser entendida como uma finalidade em si mesma, muito menos como um obstáculo às recomendações técnicas. A maior 
ou menor autonomia de que reclama um ou outro indivíduo, neste ou naquele aspecto do seu cotidiano, sinaliza, na verdade regiões de vulnerabilidade, áreas relacionais (interpessoais, sociais, programáticas) que requerem atenção especial para que êxito técnico e sucesso prático possam de fato interagir de forma construtiva e adequada aos projetos de felicidade dos idosos. Ao ser construída e compreendida apenas nos contextos concretos de interação cotidiana dos idosos, a autonomia vai ganhando diferentes feições em decorrência das distintas situações da prática, o que impõe pensá-la não como um atributo individual (que o idoso ainda tem ou que já perdeu), mas como um marcador de características relacionais que reclamam estratégias técnicas e horizontes prático-morais plurais e flexíveis, sempre desde um mesmo horizonte ético de respeito ao outro e responsabilidade em relação a ele. 


\title{
6 CONSIDERAÇÕES FINAIS
}

\begin{abstract}
A gente sentia: até que ponto a gente vai? (Martina, 40 anos)
Até onde vai nosso direito de interferir e até onde vai o direito da autonomia daquele idoso de dizer não e ponto? (Débora, assistente social)
\end{abstract}

A questão da autonomia, do limite da técnica, ou mesmo a pergunta "até onde temos o direito de ir?" nem sempre aparece de forma explícita nos diálogos sobre a atenção ao idoso. Mas na vivência - a cada decisão, construção de plano terapêutico ou encontro - as dificuldades, facilidades e perspectivas tensionam o limite da técnica e são relatados de formas diversas nas histórias, como visto nas narrativas.

As dificuldades vividas e os caminhos traçados se dão de forma intersubjetiva, tal qual a autonomia que se manifesta de caráter relacional. Os limites, ou o tal limite da técnica, são então móveis ao longo do tempo e das fusões de horizontes que se permite ou se busca ter nas inter-relações.

As perspectivas de horizontes são individuais e a cada encontro, caso aquiesçam, profissionais, idosos, família e comunidade podem partilhar horizontes e se abrir para novas práticas.

Como diálogo que somos, se abrir para os horizontes do outro permite que os mesmos se tornem mais plurais e prósperos, atitude essencial para que se atinja o êxito técnico associado ao sucesso prático. É com esse partilhar de horizontes que se alteia uma autonomia respaldada na ética no Cuidado e que culmina com maior capacidade de ação sobre si mesmo a partir do sujeito cuidado com objetivos compartilhadamente estabelecidos.

A partir das histórias e narrativas de idosos e profissionais, vemos que alguns horizontes são tensionados no cotidiano de práticas em inter-relação com a autonomia e o limite da técnica. A observação destes horizontes pode ser uma ferramenta propedêutica com fins tanto para discernir ou "diagnosticar" os conflitos nas áreas em que é possível explorar mais os limites, quanto para acenar caminhos para abordagem nas variadas situações, permitindo enxergar 
possibilidades de intervenção para além da perspectiva que já se tem como mais comum. De maneira despretensiosa, repensar os horizontes de prática e de tensão permite mudar de foco um dos limites e perscrutar outros. Esses horizontes que participam do "limite da técnica" são o do usuário (no caso, o idoso), o do profissional, o do contexto social e o do sistema de saúde.

$O$ do usuário se abre naquilo em que ele permite ser tocado. Essa permissão se dá conforme o entendimento das tradições em que ele está imerso e das construções de vínculo. Ouvir, ver, tocar, voltar-se à presença do outro e permitir que os novos saberes práticos façam parte dessa relação predispõem à formação de laços mais fortes e à abertura de novos horizontes a partir da construção conjunta de um projeto de cuidado e de emancipação dos sujeitos envolvidos no processo terapêutico. Trata de reconhecer o horizonte do usuário, sua perspectiva e ter respeito pelas suas decisões. Esse horizonte não é dado de forma imutável, mas se move e se abre em permeabilidade com a construção do vínculo, uma vez que esse pode ser aprofundado ao longo do tempo com atitudes intencionais. É imprescindível acrescentar, em especial no caso do idoso, o horizonte da família, observando as concepções em saúde e cuidado próprio desse sistema familiar, suas tradições, cultura, contexto socioeconômico, história, sistema de relações e, da mesma forma, desenvolver vínculo e laços de confiança com a equipe ou profissional. À medida que o horizonte do profissional se funde com o do usuário, abrem-se mais portas para acessar o que é a vida que se quer ter feliz (ou o projeto de felicidade) a fim de que ambos trabalhem em prol desse objetivo comum.

O horizonte do profissional se dá no diálogo entre a tecnociência e a sabedoria prática. Pode ser enriquecido com as trocas de saberes entre os diferentes profissionais, com a capacitação técnica e cultural, além de poder beber das ciências humanas. Um profissional com um horizonte vasto, consegue gradativamente ir ampliando a capacidade de agir nos objetivos partilhadamente acordados. Ter espaços de trocas em que se discute o universo humano e profissional, as atribuições dentro de uma equipe e a valorização do horizonte de cada um, com respeito, é importante. O reconhecimento quanto a qual é o seu próprio horizonte, como pessoa e profissional, é o ponto de partida. Em outras palavras, é o se perscrutar e refletir sobre qual o seu local de fala e seu 
horizonte normativo, sua concepção de trabalho bem-sucedido. O profissional pode se fazer perguntas como: quem sou o eu que pretende participar desse cuidado? Quais as angústias pessoais que trago para esse caso? Quais as minhas ansiedades? Isso me incomoda ou efetivamente é algo que preocupa a comunidade ou o usuário? É um se conhecer para reconhecer. Com o reconhecimento se abre para novas práticas. Com o reconhecimento também se entende os próprios limites, e como lidar com eles.

O horizonte da situação contextual envolve competência cultural, orientação para a comunidade e identificação dos recursos humanos, sociais e físicos de determinada região. A vulnerabilidade social permite melhor compreender as vulnerabilidades individuais. $O$ contexto interfere no entendimento da autonomia da qual se parte e nas oportunidades diferentes de se efetivamente concretizar a autodeterminação. O contexto interfere no desenvolvimento das pessoas, no aumento ou prejuízo da capacidade funcional e independência. $O$ inconformismo e tensionamento do horizonte do contexto podem auxiliar na criação de mais oportunidades. É plausível que o idoso (ou mesmo qualquer usuário) manifeste posição negativa frente a uma determinada proposta sugerida pela equipe que o assiste porque, na prática, não tem essa opção ou, porque desconhece outros caminhos além daquele que já trilha. Enriquecer e atuar sobre o contexto é enriquecer as possibilidades de atuação. É impulsionar o usuário a ter um maior protagonismo sobre sua vida ao contar com um ambiente social favorável ao desenvolvimento de potencialidades e descobertas de novas perspectivas. É, por outro lado, transformar padrões normativos que dominam um certo contexto em resposta às necessidades de autonomia do idoso, incluindo valores e necessidades que não "atenderão" apenas os idosos, mas podem nos tornar a todos mais ricos de possibilidades.

O horizonte do sistema, no qual localizamos vulnerabilidades de ordem programática, ou seja, onde não encontramos políticas, serviços e ações capazes de mitigar as vulnerabilidades relacionais e sociais dos idosos, implica conhecimento e integração dos diversos pontos da rede. Também envolve identificar os limites dos recursos: demanda versus oferta, necessidades do idoso e sua família, e continência ou não dessas necessidades na perspectiva da saúde, da rede ou dos setores da sociedade. Os diagnósticos que indicam as 
fragilidades e apontam para incremento e aprimoramento de uma rede de atenção são importantes mecanismos de ampliação dos horizontes de atuação. Requer uma postura crítica, porém ativa, de transformação para proporcionar abertura a diversos caminhos de cuidado.

É preciso se abrir em cada encontro para um novo horizonte. Procurar entender e construir conjuntamente um novo horizonte a partir do reconhecimento de quem é aquele que fala, quem sou o eu que está em diálogo e de onde travamos esse diálogo (perspectivas social e programática), num reconhecimento e fusão de horizontes crítica e reconstrutiva. Assim o limite da técnica se dá num exercício de dialética e movimento de fusão de horizontes entre usuário (e sua família), profissional, comunidade e sistema - dinâmico, fluido e flexível ao longo do tempo. 


\section{7 - ANEXOS}

\section{ANEXO 1 - ROTEIRO DE ENTREVISTA SEMI-ESTRUTURADA: IDOSO}

1. Caracterização do idoso - Fale-me um pouco de você. Apresente-se para mim. Diga o que quiser, o que estiver com vontade. Como está a sua vida hoje? Onde nasceu? Mora há quanto tempo na Barra Funda? Como veio morar aqui no bairro? E nessa casa? - Caracterização do entrevistado: nome, data do nascimento, procedência, tempo de moradia em São Paulo e na Barra Funda, estado civil, escolaridade (anos de estudo e se sabe ler), cor, religião, tipo de moradia e composição do núcleo familiar, renda familiar, situação trabalhista e previdenciária.

2. Identidade - Você se sente idoso? Você se lembra de quando começou a se sentir assim? Você se lembra de uma situação especial que o fez se sentir idoso? Como você se sente quanto a sua saúde (dificuldades, facilidades)?

3. Envelhecimento saudável - Para você, o que é envelhecer bem?

4. Projeto de felicidade - Quais são seus planos para o futuro? Você identifica obstáculos a esses planos? Quais? Como pretende superá-los?

5. Para você, o que significa ter uma vida bem sucedida?

6. Capacidade funcional - Você consegue fazer as coisas que gostaria de fazer? Se lembra de algum momento em que não conseguiu? Normalmente precisa de ajuda para quais atividades no seu dia a dia?

7. Diálogo - Se lembra de alguma situação especial relacionada com a sua saúde em que sua opinião era diferente da ideia dos profissionais? Como foi? Como se sentiu?

8. Autonomia/Responsabilização/Co-construção / Adesão - Você sente que as pessoas ao seu redor respeitam as suas escolhas? Conte-me uma experiência de quando sentiu que não foi respeitado. Como você agiu? Como acontece no seu atendimento caso não concorde com o que é feito? Já aconteceu alguma vez em que, depois de uma conversa, você mudou de ideia. Conte-me como foi.

9. Vínculo / voltar-se ao outro- Como você se sente com relação ao cuidado que a equipe de saúde tem com você? Se lembra de alguma situação em que se sentiu bem cuidado? E de alguma de qual não gostou de como foi cuidado? Como você agiu? 
10. Família - E em relação à sua família, como se sente com o cuidado que ela Ihe oferece? Se lembra de uma situação em que foi bem cuidado? E de alguma da qual não gostou de como Ihe trataram? Como você agiu?

11. Rede e intersetorialidade- Costuma frequentar algum local com atividades voltadas para a terceira idade? Como se sente lá? Sente que falta ter algum tipo de serviço assim? 


\section{ANEXO 2 ROTEIRO DE ENTREVISTA SEMI-ESTRUTURADA: PROFISSIONAL DA SAÚDE}

1. Caracterização do profissional - Fale-me um pouco de você. Apresentese para mim. Diga o que quiser, o que estiver com vontade. Como está a sua vida hoje? Onde nasceu? Trabalha há quanto tempo no CS? Caracterização do entrevistado: nome, data do nascimento, procedência, tempo de moradia em São Paulo e na Barra Funda, estado civil, escolaridade, cor, religião.

2. Identidade - Como você nota que um paciente está ficando realmente idoso?

3. Projeto de felicidade - Você costuma se preocupar sobre quais os planos do seu paciente idoso? Caso negativo, por que? Caso positivo, que tipo de planos são? Você identifica obstáculos a esses planos? Quais? Que tipo de ajuda o serviço pode oferecer para superá-los?

4. Envelhecimento saudável - Para você o que é envelhecer bem? O que é uma velhice bem sucedida?

5. Capacidade funcional - Como você avalia a capacidade funcional dos idosos? Quais as restrições funcionais que encontra com maior frequência? Quais considera as mais importantes? Quais as mais fáceis de lidar? Quais as mais difíceis? Conte-me um exemplo de como lidou com uma limitação funcional que achou ter sido fácil e de uma em que foi difícil lidar.

6. Diálogo - Conte-me de uma situação em que teve muita dificuldade em lidar com o cuidado do idoso. Quais as principais dificuldades que apresenta no dia a dia para atender ao idoso?

7. Autonomia/Responsabilização/Co-construção / Adesão - Conte-me uma experiência em que a proposta de cuidado que tinha para o idoso era diferente daquela que ele gostaria. Como você se sentiu? Como reagiu? Como resolveu a situação?

8. Vínculo / Voltar-se ao outro - Conte-me sobre uma situação que lembra que gostou de como cuidou de um idoso da sua região. Você tem alguma ideia ou sugestão de melhoria de processo de trabalho ou estrutura da unidade para melhor atender ao idoso? 
9. Família - Como é para você a relação com a família ou os cuidadores do idoso? Já viveu alguma situação em que o desejo deles era diferente do desejo do idoso? Como resolveu isso?

10. Rede e intersetorialidade- A quem ou ao que você recorre quando tem uma situação difícil para tratar em relação a saúde do idoso? 


\section{ANEXO 3 - ROTEIRO DE OBSERVAÇÃO PARTICIPANTE}

Privilegiará a observação a partir de 2 eixos: o ambiente físico e o relacional

\section{Ambiente físico (território e estrutura física da UBS)}

A. Observar características do território: moradias, acesso à UBS (facilidades e limitações geográficas), presença de serviços necessários ao dia a dia (mercados, farmácias, bancos, restaurantes e lanchonetes), transporte público.

B. Observar características da UBS: espaços comuns (recepção, acolhimento, sala de espera, fila para retirada de medicamentos, salas para reuniões em grupo, banheiros) e como se dá a trajetória (tanto de mobilidade quanto de atendimento) do idoso nestes espaços. Assim observando se há atendimento preferencial, se normalmente o idoso está acompanhado ou só, se o acompanhante fala mais e decide pelo idoso, as facilidades e dificuldades nesses espaços, as adaptações e as relações com os outros usuários e profissionais do serviço.

\section{Ambiente relacional}

A. Interação idoso e equipe saúde da família

Observação dessa interação em diferentes cenários: atendimento ambulatorial, domiciliar, grupos e acolhimento.

Como é o reconhecimento do idoso por parte da equipe e dos funcionários da UBS. Critérios por idade, por aparência?

Características gestuais idoso e profissionais durante os encontros postura, contato visual, tom de voz, característica da voz do profissional e do idoso durante a interação (exemplo: alto, suave, fluente, lentificada).

Diálogo - escuta, tempo de interação, como (se) são abordados aspectos como interesses, prazeres, planos, estado de ânimo (projeto de felicidade) do idoso, como acontece a responsabilização, co-construção, decisão 
compartilhada, fusão de horizontes. Presença de outros indivíduos na conversa (exemplo: familiar). Caso presente, observar a dinâmica, quem domina a conversa. Se a queixa ou proposta trazida pelo idoso condiz com o que o familiar expressa.

Avaliação da capacidade funcional - se, como, e em que circunstâncias é feita.

B. Interação entre os próprios profissionais da equipe saúde da família

Processo de trabalho - como são organizados os atendimentos para os idosos (tempo, espaço, interação da equipe durante os atendimentos, apoio para momentos antes e depois da consulta).

Como acontecem as discussões sobre os problemas que envolvem os idosos.

Quais os principais problemas que a equipe levanta durante as conversas (reuniões de equipe e passagens de casos em outros momentos).

O que mais toca a equipe quanto ao cuidado do idoso.

Quais são os pontos de acordo mais fácil

Quais são os conflitos mais difíceis de resolver

Como a equipe se articula para resolver as dificuldades que encontra. A quem ou ao que procura. 


\title{
ANEXO 4 - TERMO DE CONSENTIMENTO LIVRE E ESCLARECIDO
}

\author{
Caro Participante:
}

Gostaríamos de te convidar para participar voluntariamente da pesquisa intitulada "O cuidado do idoso na atenção primária sob o olhar da autonomia: um estudo em bairro central da Cidade de São Paulo" que se refere a um projeto de Mestrado da pesquisadora Jeane Lima e Silva Carneiro, sob a orientação de José Ricardo C. M. Ayres, o qual pertence ao Departamento de Medicina Preventiva da Universidade de São Paulo e tem como pesquisadora responsável no

a Dra Karina Moraes Kiso.

Este estudo tem como objetivo compreender como a equipe multidisciplinar e o idoso lidam com a autonomia no dia a dia na atenção primária a saúde.

Sua participação ocorrerá por meio de uma entrevista, que será gravada para melhor registro das informações, e por meio da observação de atendimentos. Os registros serão utilizados para a produção de trabalhos científicos relacionados à esta pesquisa.

Este estudo contribuirá para melhorar as ações de cuidado com o idoso, considerando a sua autonomia como sujeito, na atenção primária.

Seu nome não será utilizado em qualquer fase da pesquisa, o que garante seu anonimato, e a divulgação dos resultados será feita de forma a não identificar os voluntários.

Não será cobrado nada, não haverá gastos e não estão previstos ressarcimentos ou indenizações, pois o estudo envolve somente entrevista e nenhum procedimento ou intervenção será realizado no(a) senhor(a).

Considerando que toda pesquisa oferece algum tipo de risco, nesta pesquisa o risco pode ser avaliado como: mínimo. Devido apenas ao caso de se sentir incomodado(a) com a entrevista.

Gostaríamos de esclarecer que sua participação é voluntária e que poderá recusar-se a participar ou retirar o seu consentimento, ou ainda descontinuar sua participação se assim o preferir, sem penalização alguma ou sem prejuízo ao seu cuidado.

Caso aceite participar voluntariamente do estudo o(a) senhor(a) ficará com uma cópia deste Termo de Consentimento Livre e Esclarecido.

Em qualquer etapa do estudo, o senhor(a) terá acesso aos profissionais responsáveis pela pesquisa para esclarecimento de dúvidas: 


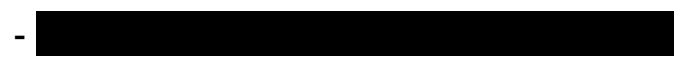

Pesquisadora Responsável: Dra Karina Moraes Kiso

\section{Endereço:}

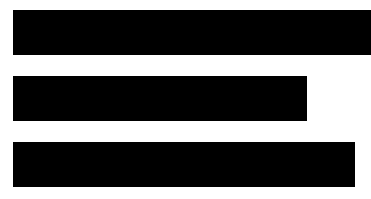

Pesquisadora Assistente: Jeane Lima e Silva Carneiro

Endereço: Av. Doutor Abrahão Ribeiro, 283 - Secretaria de Ensino e Pesquisa

Várzea da Barra Funda - São Paulo - SP

CEP: 01133-020,

Telefone: $3466-2500$

Celular: $94115-1040$

Ou no endereço da Instituição Proponente do Estudo:

Av. Dr. Arnaldo, 455 - Departamento de Medicina Preventiva

Cerqueira César - São Paulo - SP

CEP: 01246-000

Telefone: (11) 3061-7094

Se você tiver alguma consideração ou dúvida sobre a ética da pesquisa, entre em contato com o Comitê de Ética em Pesquisa da Irmandade da Santa Casa de Misericórdia de São Paulo (CEP/SC) - Rua: Santa Isabel, 305 - 4ํandar - Fone: (11) 2176-7689 - Email: cepsc@santacasasp.org.br.

Desde já, agradecemos sua atenção e participação e colocamo-nos à disposição para maiores informações.

Acredito ter sido suficientemente informado a respeito das informações que li ou que foram lidas para mim, descrevendo o estudo "O cuidado do idoso na atenção primária sob o olhar da autonomia: um estudo em bairro central da Cidade de São Paulo". 
Eu discuti com a Drª Karina Moraes Kiso e/ou com a pesquisadora Jeane Lima e Silva Carneiro sobre a minha decisão em participar nesse estudo.

Ficaram claros para mim quais são os propósitos do estudo, os procedimentos a serem realizados, seus desconfortos e riscos, as garantias de confidencialidade e de esclarecimentos permanentes. Ficou claro também que minha participação é isenta de despesas e que tenho garantia do acesso a tratamento hospitalar quando necessário. Concordo voluntariamente em participar do estudo e poderei retirar o meu consentimento a qualquer momento, antes ou durante o mesmo, sem penalidades ou prejuízo ou perda de qualquer benefício que eu possa ter adquirido, ou no meu atendimento neste serviço.

Assinatura do Participante da Pesquisa / Responsável Legal

Data I

Assinatura da testemunha.

Data /

Para casos de voluntários, analfabetos, semianalfabetos ou portadores de deficiência auditiva ou visual: declaro que obtive de forma apropriada e voluntária o Consentimento Livre e Esclarecido deste paciente ou representante legal para a participação neste estudo.

Assinatura do Pesquisador Responsável pelo estudo

Data 1

Digite aqui o subtítulo

Digite aqui o Conteúdo 


\section{ANEXO 5 - Genograma e Ecomapa}

O Genograma é uma ferramenta utilizada para armazenamento e informações sobre a família. Por meio do uso de ícones convencionalmente utilizados em genética, possibilita a avaliação da estrutura da família, das relações entre os membros da família, do contexto familiar e os processos de adoecimento, dos padrões transgeracionais, do vínculo e a inclusão de aspectos que podem auxiliar nas ações voltadas para saúdedoença e cuidado. Assim, trata-se de uma representação gráfica da família que permite aliar tanto o olhar biomédico (a partir do registro de problemas de saúde) quanto o psicossocial (por facilitar o entendimento dos problemas inseridos em contextos). Em geral deve incluir ao menos três gerações. Os membros da família são colocados em séries horizontais (indicando linhagem de geração), os filhos em ordem decrescente, começando do mais velho para o mais novo. Casamento, divórcio, união estável, morte e os demais eventos da vida são indicados por linhas e símbolos específicos. Há também linhas de diferentes padrões para configurar as relações (proximidade, distanciamento, relacionamento fusionado, abuso e assim por diante). Já o ecomapa representa as relações da família com o meio externo, quer sejam importantes ou que geram conflitos. A partir das linhas de fluxo indica como se dá essa relação. Ao mapear as redes de um indivíduo ou família, permite a identificação de pontos de intermediação ou de recursos que podem ser mobilizados para resolução de conflitos (BRASIL. MINISTÉRIO DA SAÚDE, 2013; BRASIL, 2006). Há algumas sistematizações para os símbolos com pequenas variações entre as diferentes fontes. A figura a seguir apresenta os utilizados nesse trabalho: 


\section{Genograma - símbolos}

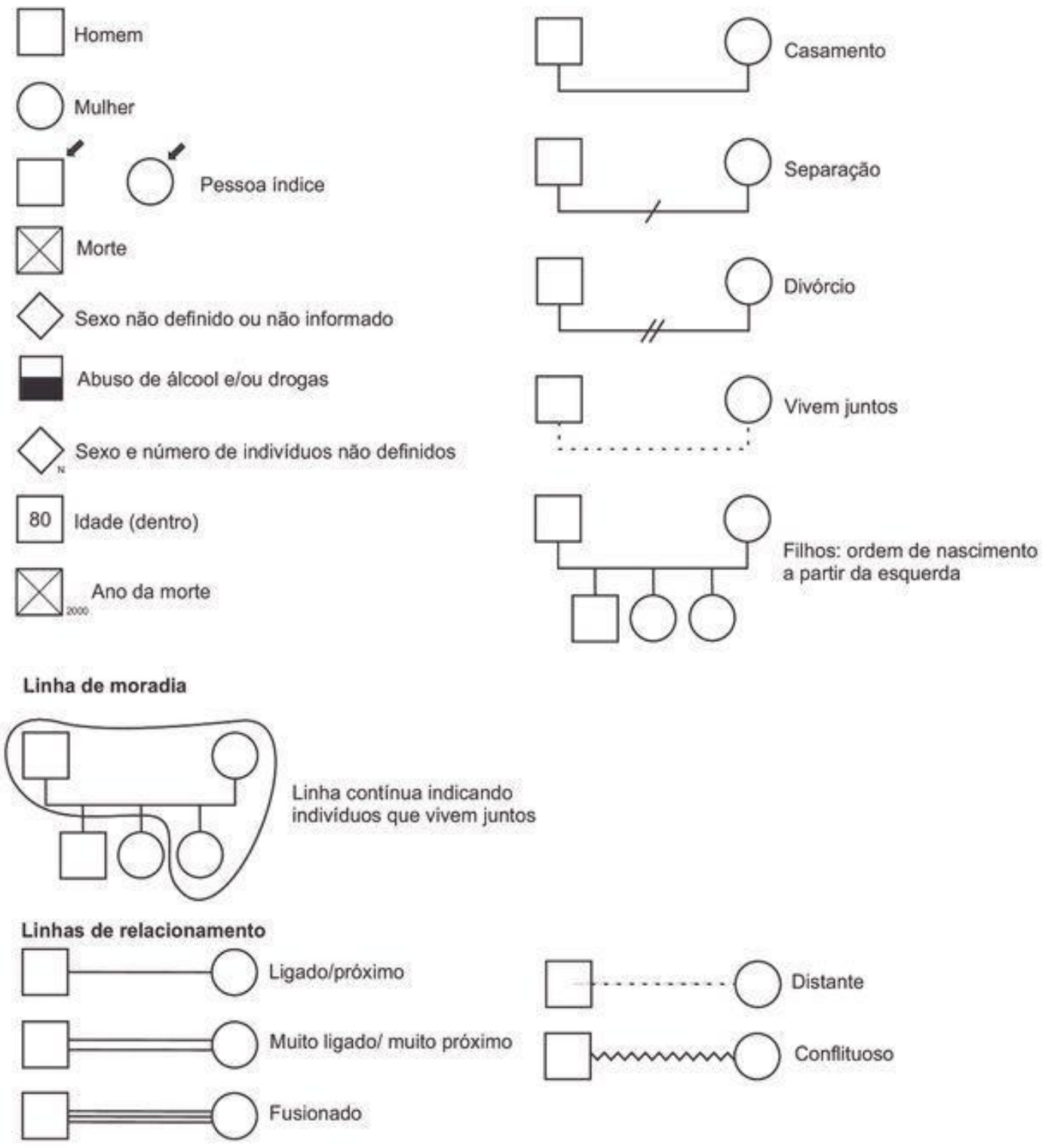

\section{Ecomapa - diagrama de vínculos} Ligaçăo forte, relaçăo sólida

........ Ligação frágil, relação tênue

$\longrightarrow$ Fluxo de energia e/ou recursos

Adaptado de McGoldrick (2005) disponível em Caderno de Atenção Domiciliar Volume 2 (Brasil. Ministério da Saúde, 2013). 


\section{8 - REFERÊNCIAS}

Almeida AK, Maia EMC. Amizade, idoso e qualidade de vida: revisão bibliográfica. Psicologia em Estudo. 2010;15(4):743-50.

Andrade SCV, Marcucci RMB, Faria LFC, Paschoal SMP, Rebustini F, Melo RC. Perfil de saúde dos idosos assistidos pelo Programa Acompanhante de Idosos na Rede de Atenção à Saúde do Município de São Paulo. Einstein (São Paulo). 2020;18.

Araújo MAS, Brito $\mathrm{C}$, Barbosa MA. Atenção básica à saúde do idoso no Brasil: limitações e desafios. 2008.

Argota JMV. Supervivencia excepcional y longevidad satisfactoria: un enfoque desde la bioética. Revista latinoamericana de bioética. 2009;9(2):86-91.

Asen E. Ingredientes da abordagem sistêmica. In: Artmed, editor. Dez minutos para família: intervenções sistêmicas em Atenção Primária à Saúde. Porto Alegre: Asen , E et al.; 2012.

Assis M. Promoção da Saúde e Envelhecimento: avaliação de uma experiência no ambulatório do Núcleo de Atenção ao Idoso da UnATI/UERJ 2004.

Assis MMA, Jesus WLA. Acesso aos serviços de saúde: abordagens, conceitos, políticas e modelo de análise. Ciência \& Saúde Coletiva. 2012;17:2865-75.

Ayres J, França Júnior I, Calazans GJ, Saletti Filho HC. O conceito de vulnerabilidade e as práticas de saúde: novas perspectivas e desafios. Promoção da saúde: conceitos, reflexões, tendências. 2003;2:121-44.

Ayres JRCM. Cuidado e reconstrução das práticas de saúde. InterfaceComunicação, Saúde, Educação. 2004a;8(14):73-92.

Ayres JRCM. O cuidado, os modos de ser (do) humano e as práticas de saúde. Saúde e sociedade. 2004b,13(3):16-29.

Ayres JRCM. Uma concepção hermenêutica de saúde. Physis: Rev. Saúde Coletiva. 2007, 17( 1 ): 43-62.

Ayres JRCM. Organização das ações de atenção à saúde: modelos e práticas. Saúde e Sociedade. 2009b;18:11-23.

Ayres JRCM. Para comprender el sentido práctico de las acciones de salud: contribuciones de la hermenéutica filosófica. Salud colectiva. 2008;4:159-72.

Ayres JRCM. Prevenção de agravos, promoção da saúde e redução de vulnerabilidade. Clínica Médica [2ed ampl rev]: Manole; 2009c. 
Ayres JRCM. Sujeito, intersubjetividade e práticas de saúde. In: - C-IU, ABRASCO, editors. Cuidado : trabalho e interação nas práticas de saúde. 1. Rio de Janeiro: Ayres, JRCM; 2009a. p. 282 p. p. 17-39.

Barbosa KTF, Oliveira FMRL, Fernandes MdGM. Vulnerability of the elderly: a conceptual analysis. Revista Brasileira de Enfermagem. 2019;72:337-44.

Brasil MS. Atenção Domiciliar na Atenção Primária à Saúde Brasília, Ministério da Saúde, .Secretaria de Atenção Especializada a Saúde, Departamento de Atenção Hospitalar, Domiciliar e Urgência. 2020. p. 98.

Brasil MS. Caderno de Atenção Domiciliar. Brasília: Ministério da Saúde; 2013.

Brasil MS. Síntese de evidências para políticas de saúde: adesão ao tratamento medicamentoso por pacientes portadores de doenças crônicas. Brasília: Ministério da Saúde/Secretaria de Ciência, Tecnologia e Insumos Estratégicos, Departamento de Ciência e Tecnologia / EVIPNet Brasil; 2016. p. 52.

Brasil. Decreto n. 1.948, de 3 de julho de 1996. Brasília, DF.1996.

Brasil. Envelhecimento e saúde da pessoa idosa-Cadernos de Atenção Básica. MS Brasília; 2006.

Brasil. Guia de Políticas, Programa e Projetos do Governo Federal para a População Idosa : Compromisso Nacional para o Envelhecimento Ativo. Brasília: Secretaria de Direitos Humanos da Presidência da República; 2015.

Brasil. Orientações técnicas para a implementação de Linha de Cuidado para Atenção Integral à Saúde da Pessoa Idosa no Sistema Único de Saúde . . Brasília: Ministério da Saúde. Secretaria de Atenção à Saúde Departamento de Ações Programáticas e Estratégicas; 2018. p. 94.

Brasil. Portaria n. 2.528, de outubro de 2006. Brasília: Diário Oficial da União; 2006.

Brito TRP, Nunes DP, Duarte YAO, Lebrão ML. Redes sociais e funcionalidade em pessoas idosas: evidências do estudo Saúde, Bem-Estar e Envelhecimento (SABE). Revista Brasileira de Epidemiologia. 2018;21.

Brunello MEF, Ponce MAZ, Assis EG, Andrade RLP, Scatena LM, Palha PF, et al. O vínculo na atenção à saúde: revisão sistematizada na literatura, Brasil (19982007). Acta paulista de Enfermagem. 2010;23(1):131-5.

Burlá C, Pessini L, Siqueira JE, Nunes R. Envelhecimento e doença de Alzheimer: reflexões sobre autonomia e o desafio do cuidado. Revista Bioética. 2014;22(1):85-93.

Camarano AA, Kanso S, Mello J, Leitão E. Como vive o idoso brasileiro? Rio de Janeiro: IPEA; 2004. 
Campos GWS, Domitti AC. Apoio matricial e equipe de referência: uma metodologia para gestão do trabalho interdisciplinar em saúde. Cadernos de saúde pública. 2007;23(2):399-407.

Campos RTO, Campos GS. Co-construção de autonomia: o sujeito em questão. Tratado de saúde coletiva. 2006;1:669-88.

Campos RTO, Ferrer AL, Gama CAP, Campos GWS, Trapé TL, Dantas DV. Avaliação da qualidade do acesso na atenção primária de uma grande cidade brasileira na perspectiva dos usuários. Saúde em Debate. 2014;38:252-64.

Cohen C, Gobbetti G. Bioética da vida cotidiana. Ciência e cultura. 2004;56(4):479.

Costa NRCD, de Aguiar MIF, Rolim ILTP, Rabelo PPC, Oliveira DLA, Barbosa YC. Política de Saúde do Idoso: Percepção dos profissionais sobre sua Implementação na Atenção Básica. Revista de Pesquisa em Saúde. 2015;16(2).

Debert GG. Envelhecimento e representações sobre a velhice. Anais do VI Encontro Nacional de Estudos Populacionais; Olinda - PE: Associação Brasileira de Estudos Populacionais; 1988. p. 537-56.

Debert GG. Velhice e o curso da vida pós-moderno. Revista USP. 1999 (42):70-83

Duarte YAO, Nunes D, Corona L, Lebrão M. Como estão sendo cuidados os idosos frágeis de São Paulo? A visão mostrada pelo estudo SABE (Saúde, Bemestar e Envelhecimento). Cuidados de longa duração para a população idosa: um novo risco social a ser assumido. 2010;1:123-44.

Fernandes MTO, Soares SM. O desenvolvimento de políticas públicas de atenção ao idoso no Brasil. Revista da Escola de Enfermagem da USP. 2012;46(6):1494502.

Ferreira FR, César CC, Andrade FB, Souza Junior PRB, Lima-Costa MF, Proietti FA. Aspectos da participação social e a percepção da vizinhança: ELSI-Brasil. Revista de Saúde Pública. 2018;52:18s.

Franco CAGS, Kusma SZ. Envelhecer em família: particularidades e crenças. Revista Gestão \& Saúde [Internet]. 2009; 1:[11-6 pp.].

Freitas JGA, Nielson SEO, Porto CC. Adesão ao tratamento farmacológico em idosos hipertensos: uma revisão integrativa da literatura. Rev Soc Bras Clin Med. 2015;13(1):75-84.

Fripp JC. Ação prática do paliativista na continuidade dos cuidados em domicílio. In: Sulina, editor. Manual de cuidados paliativos da Academia Nacional de Cuidados Paliativos. Porto Alegre: Academia Nacional de Cuidados Paliativos.; 2012. p. 375-91. 
Gadamer H-G. Verdade e método: Traços fundamentais de uma hermenêutica filosófica. Bragança Paulista - SP: Editora Universitária; 2015. 631 p.

Giacomin KC, Duarte YAO, Camarano AA, Nunes DP, Fernandes D. Cuidado e limitações funcionais em atividades cotidianas-ELSI-Brasil. Revista de Saúde Pública. 2018;52:9s.

Gomes MCPA, Pinheiro R. Acolhimento e vínculo: práticas de integralidade na gestão do cuidado em saúde em grandes centros urbanos. InterfaceComunicação, Saúde, Educação. 2005;9:287-301.

Groisman D. A velhice, entre o normal e o patológico. História, ciências, saúdeManguinhos. 2002;9(1):61-78.

Hojaij NHSL, Oliveira RA. A bioética no envelhecimento. Envelhecimento: uma visão interdisciplinar: Atheneu; 2015.

IBGE - Pesquisa Nacional por Amostra de Domicílios Contínua: Características gerais dos domicílios e dos moradores : 2019. Rio de Janeiro: IBGE, Coordenação de Trabalho e Rendimento, 2020.

Lavras C. Atenção primária à saúde e a organização de redes regionais de atenção à saúde no Brasil. Saúde e Sociedade. 2011;20:867-74.

Lemos CES. Entre o Estado, as famílias e o mercado. Revista Sinais Sociais/SESC- Serviço Social do Comércio. 2013;8(22):9-86.

Lichtenfels $\mathrm{P}$, Santos MHS, Fernandes EO. O cuidado do paciente idoso. In: Artmed, editor. DUNCAN, B.B: Medicina ambulatorial: condutas de Atenção Primária baseadas em evidências. 4. Porto Alegre: 2013. p. 658-9.

Lima ÂMM. Saúde e envelhecimento: o autocuidado como questão. São Paulo: Tese de Doutorado - Universidade de São Paulo; 2003.

Lothian K, Philp I. Care of older people: Maintaining the dignity and autonomy of older people in the healthcare setting. Bmj. 2001;322(7287):668-70.

Loyola Filho Al, Firmo JOA, Mambrini JVM, Peixoto SV, Souza Junior PRB, Andrade FB, et al. Subutilização de medicamentos por motivos financeiros em adultos mais velhos: ELSI-Brasil. Revista de Saúde Pública. 2018;52:8s.

Lubben J. Addressing social isolation as a potent killer! Public Policy \& Aging Report. 2017;27(4):136-8.

Macedocouto GS, da Silva Junior AF. Solidão: do patológico ao ontológico. Estudos e Pesquisas em Psicologia. 2017;17(1):7-24.

Marques EIW, Petuco VM, Gonçalves CBC. Motivos da não adesão ao tratamento médico prescrito entre os idosos de uma unidade de saúde da família do município de Passo Fundo-RS. Revista Brasileira de Ciências do Envelhecimento Humano. 2010;7(2). 
Merhy EE. Um ensaio sobre o médico e suas valises tecnológicas: contribuições para compreender as reestruturações produtivas do setor saúde. Interfacecomunicação, saúde, educação. 2000;4:109-16.

Minayo MC, Assis SG, Souza ER. Avaliação por triangulação de métodos: abordagem de programas sociais. Rio de Janeiro: FIOCRUZ; 2016. 407 p.

Minayo MC. O desafio do conhecimento: pesquisa qualitativa em saúde. São Paulo: HUCITEC; 2014.

Motta AB. Envelhecimento e sentimento do corpo. Antropologia, saúde e envelhecimento. 2002:37-50.

Moura JdC. Interações e comunicação entre médicos e pacientes na atenção primária à saúde: um estudo hermenêutico: Universidade de São Paulo; 2012.

Myers L, Palmarini N. Loneliness: findings from IBM's Institute for business value 2017 study on loneliness in the aging population. Public Policy \& Aging Report. 2017;27(4):158-9.

Nogueira IRR, Alcântara AO. Envelhecimento do homem: de qual velhice estamos falando? Revista Kairós: Gerontologia. 2014;17(1):263-82.

Ong AD, Uchino BN, Wethington E. Loneliness and health in older adults: A minireview and synthesis. Gerontology. 2016;62(4):443-9.

OPAS La Renovación de la atención primaria de salud en la Américas: Documento de Posición de la Organización Panamericana de la Salud/Organización Mundial de la Salud (OPS/OMS). 2007.

Palmer RE. Hermenêutica 2014. 274 p.

Paranhos DG, Albuquerque A. A autonomia do paciente idoso no contexto dos cuidados em saúde e seu aspecto relacional. Revista de Direito Sanitário. 2018;19(1):32-49.

Pinheiro TF. Camisinha, homoerotismo e os discursos da prevenção de HIV/Aids: Universidade de São Paulo; 2015.

Ricoeur P, Corona P. Del texto a la acción: ensayos de hermenéutica II: Fondo de cultura económica Buenos Aires; 2002. 380 p.

Ricoeur P, Morão A. Teoria da interpretação: o discurso e o excesso de significação;1987. 109 p.

Schneider $\mathrm{RH}$, Irigaray TQ. $\mathrm{O}$ envelhecimento na atualidade: aspectos cronológicos, biológicos, psicológicos e sociais. Estudos de Psicologia (Campinas). 2008;25(4):585-93.

Schraiber LB, Mendes-Gonçalves RB. Necessidades de saúde e atenção primária. Saúde do adulto: programas e ações na unidade básica1996. p. 29-47. 
Schraiber LB. No encontro da técnica com a ética: o exercício de julgar e decidir no cotidiano do trabalho em medicina. Interface-Comunicação, Saúde, Educação. 1997;1:123-40.

Secretaria Municipal de Direitos Humanos e Cidadania. Indicadores sociodemográficos da população idosa na cidade de São Paulo . São Paulo; 2019.

Silva LM, Moreira MASP, Bezerra VP, Almeida SA, Brenna S, Silva AO. Representações sociais sobre solidão por idosos institucionalizados. Revista de Pesquisa Cuidado é Fundamental Online. 2014;6(5):1-9.

Sirena S, Moriguchi E. Avaliação Multidimensional do Idoso. In: Artmed, editor. Medicina Ambulatorial : Condutas de Atenção Primária Baseadas em evidências 1. Porto Alegre. 2013. p. 665-72.

Smebye KL, Kirkevold M, Engedal K. Ethical dilemmas concerning autonomy when persons with dementia wish to live at home: a qualitative, hermeneutic study. BMC health services research. 2015;16(1):1-12.

Soares JCRS, Camargo Jr KR . Patient autonomy in the therapeutic process as a value for health. Interface-Comunicação, Saúde, Educação. 2007;3.

Starfield B. Atenção primária: equilíbrio entre necessidades de saúde, serviços e tecnologia: Brasília, DF: UNESCO; 2002.

Stewart M, Brown JB, Weston WW, McWhinney IR, McWilliam CL, Freeman TR. Medicina centrada na pessoa: transformando o método clínico: Artmed Editora; 2017.

Takeda S. A organização de serviços de Atenção Primária à Saúde. In: Duncan BB SM, Giugliani ERJ., editor. Medicina Ambulatorial: Condutas de Atenção Primária Baseadas em Evidências. Porto Alegre: Artmed; 2013. p. 19-31.

Tavares AR, Pires Cl, Simões JA. Autonomia do idoso: perspectiva ética, médica e legal. Revista Portuguesa de Bioética. 2011;15:329-52.

Tavares RE, Jesus MCP, Machado DR, Braga VAS, Tocantins FR, Merighi MAB. Healthy aging from the perspective of the elderly: an integrative review. Revista Brasileira de Geriatria e Gerontologia. 2017;20(6):878-89.

Tesser CD, Norman AH, Vidal TB. Acesso ao cuidado na Atenção Primária à Saúde brasileira: situação, problemas e estratégias de superação. Saúde em Debate. 2018;42:361-78.

Tesser CD, Poli Neto P, Campos GWS. Acolhimento e (des) medicalização social: um desafio para as equipes de saúde da família. Ciência \& Saúde Coletiva. 2010;15:3615-24. 
United Nations. World Economic and Social Survey: Development in an Ageing Word: 60th Anniversary Edition - 1948-2007 2007.

United Nations. World Population Ageing 2019: Highlights. 2019.

Veras R. Envelhecimento populacional contemporâneo: Demandas, Desafios e inovações. Revista de Saúde Pública. 2009;43:548-54.

Veras RP, Oliveira M. Envelhecer no Brasil: a construção de um modelo de cuidado. Ciência \& saúde coletiva. 2018;23:1929-36.

Walsh F. A família no estágio tardio da vida. Carter B, McGoldrick M, organizadoras As mudanças no ciclo de vida familiar: uma estrutura para a terapia familiar 2a ed Porto Alegre: Artes Médicas. 1995:269-87.

Welford C, Murphy K, Rodgers V, Frauenlob T. Autonomy for older people in residential care: A selective literature review. International Journal of Older People Nursing. 2012;7(1):65-9.

Word Health Organization. Active ageing: A policy framework. World Health Organization; 2002.

Word Health Organization. Declaração de Alma-Ata. Conferência Internacional sobre Cuidados de Saúde. URSS, Acedido em http://www. OPAS. org. br/coletiva/uploadArq/Alma-Ata. pdf; 1978.

Word Health Organization. Relatório mundial de envelhecimento e saúde. Suíça, Switzerland: World Health Organization. 2015.

Word Health Organization. The uses of epidemiology in the study of the elderly: report of a WHO Scientific Group on the Epidemiology of Aging [meeting held in Geneva from 11 to 17 January 1983]: World Health Organization; 1984. 